\title{
SOVEREIGN ASSETS AND LIABILITIES MANAGEMENT
}

\author{
Edited by
Marcel Cassard and \\ Edited by
Marcel Cassard and \\ David Folkerts-Landau
}

Proceedings of a conference held in Hong Kong SAR 


\title{
SOVEREIGN ASSETS AND LIABILITIES MANAGEMENT
}

Proceedings of a conference held in Hong Kong SAR

\author{
Edited by \\ Marcel Cassard and \\ David Folkerts-Landau
}


(c) 2000 International Monetary Fund

Cover design: Massoud Etemadi

Figures: Theodore F. Peters, $J r$.

Composition: Julio R. Prege

IMF Graphics Section

\section{Cataloging-in-Publication Data}

Sovereign assets and liabilities management / introd. by Marcel Cassard.-Washington, D.C. : International Monetary Fund, 2000

p. $\mathrm{cm}$.

Papers presented at a conference hosted by the international Monetary Fund and Hong Kong Monetary Authority, held in Hong Kong, November 1996.

Includes bibliographical references

ISBN 1-55775-694-5

1. Asset-liability management-Congresses. 2, Risk management-Congresses. 3. Debts, External-Congresses. 4. Debts, Public-Congresses. 5. Banks and banking, Central-Congresses. 6. Foreign exchange-Congresses I. Cassard, Marcel. II. International Monetary Fund. III. Hong Kong Monetary Authority.

HC1615.25.S69 2000

Price: US\$26.00

Address orders and inquiries to:

International Monetary Fund, Publication Services 700 19th Street, N.W., Washington, D.C. 20431, U.S.A. Telephone: (202) 623-7430; Telefax: (202) 623-7201

E-mail: publications@imf.org Internet: htp://www.imf.org

\section{(C) International Monetary Fund. Not for Redistribution}




\section{Contents}

Acknowledgments..........................

1 Introduction

. Marcel Cassard

2 Management of Sovereign Assets and liabilities

. Marcel Casiard ard Davel Folkerts-Landan 8

3 Debt and Asset Management and Financial Crises:

Seliers Beware

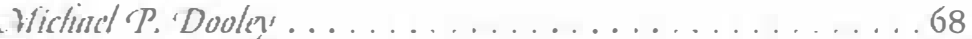

Comments by Philippe Jorion . . . . . . . . . . . . . 90

4 Foreign Currency Liabilities in Debt Management

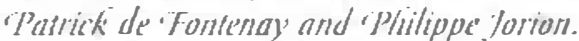

Comments by Gregory Makoff . . . . . . . . . . . . . . . . 115

5 Sovereign Liability Management: An Irish Perspective

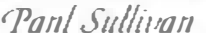

6 Management of Risks in Foreign Currency Funding and Debt Management

'Bengt 'Rödstams.

7 Autonomous Sovereign Debt Management Experience

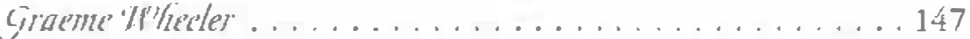

8 Public Debr Management Strategy: Belgium's Experience Louts de . Montpullict . . . . . . . . . . . . . . . . . . . . . 166

9 Central Bank Reserves Management

jolin. Arugté.

10 Trends in Central Bank Reserves Management

leam-Framsois 'Rigaud)'. 
11 Reserves Management Operations in Australia Rick Battellino . . . . . . . . . . . . . . . . . . . . . . . 217

12 Foreign Borrowing by the Kingdom of Denmark 16 Hansen . . . . . . . . . . . . . . . . . . . . . . . 227

13 Credit Costs and Borrowing Capacity in Debt Optimization Alejandro . M. Pilato . . . . . . . . . . . . . . . . . . . 236

14 Risk Management Process for Central Banks 'Thomas 'E. Klaffky', Francis 'D. Glenister; and Judith B. Otterman . . . . . . . . . . . . . . . . . . 247

15 Technical and Quantitative Aspects of Risk Management Erol. Hokanoglu. . . . . . . . . . . . . . . . . . . 263

Notes on Contributors . . . . . . . . . . . . . . . . . . . . . . 273

The following symbols have been used throughout this book:

... to indicate that dara are not available;

- to indicate that the figure is zero or less than half the final digit shown, or that the item does not exist;

- between years or months (for example, 1991-92 or January-June) to indicate the years or months covered, including the beginning and ending years or months;

/ between years or months (for example, 1991/92) to indicate a crop or fiscal (financial) year.

"Billion" means a thousand million; "rillion" means a thousand billion.

Minor discrepancies between constituent figures and totals are due to rounding. The term "country," as used in this book, does not in all cases refer to a tenitorjal entity that is a state as understood by international law and practice; the term also covers søme tertitorial entities that are not suates, but for which statstimal data are maintained and provided intemationally on a separate and independent basis. 


\section{Acknowledgments}

The success of this seminar volume is owed to the authors of the 1 papers and to the distinguished outside experts who participated in the discussions. In addition, a large number of people made invaluable contributions to this book. Most notably Sheila Kinsella, of the Research Department, gave outstanding and much needed secretarial assistance during the entire production process. Martha Bonilla, of the External Relations Department, provided excellent editorial services, shepherding the work through the production process. At an earlier stage, Jeff Gable provided first rate research assistance.

The opinions expressed in this volume are those of the authors and do not necessarily reflect the views of the IMF, its Executive Directors, or any other policymaking institutions. 
This page intentionally left blank

CInternational Monetary Fund. Not for Redistribution 


\title{
1
}

\section{Introduction}

\author{
Marcel Cassard
}

^ he papers contained in this volume were presented at a conference entitled "Sovereign Assets and Liabilities Management" hosted by the International Monetary Fund and the Hong Kong Monetary Authority in Hong Kong SAR in November 1996. The conference focused on a wide range of issues confronting policymakers in managing their sovereign assets and liabilities in a world of mobile capital flows and integrated capital markets. The papers draw on the experiences of policymakers and private sector participants that have been actively involved in formulating and implementing debt and reserves policy. The policy choices are discussed against the background of alternative theoretical frameworks that are presented by a number of academics.

In the first paper, Cassard and Folkerts-Landau focus on the design of an institutional framework that enables a sound risk management of sovereign assets and liabilities and that reduces the vulnerability of sovereign portfolios to the volatility of international capital markets. The paper recommends the assignment of sovereign debt management to a separate debt agency with a large degree of autonomy from political influence. In particular, the authors propose that the sovereign authority communicate its debt strategy and policy constraints to the debt agency in the form of a benchmark portfolio, specifying the currency composition, maturity structure, and permissible instruments of the portfolio. An analytical framework that can be used to derive a benchmark and test its robustness is then discussed. The paper stresses that public disclosure of the reserve portfolio and benchmark as well as the performance 
of portfolio managers are key to achieving sound reserve management practices.

In the second paper, Dooley advocates a conservative debt management strategy, arguing that governments should limit their issuance of debt to homogeneous long-term domestic currency instruments. His argument is based on the premise that the main consideration in structuring sovereign asset and liability management is to avoid default. The issuance of only a single class of debt is necessary to avoid an adverse selection problem for sovereign credits, while denominating public debt in domestic currency is needed to obviate the large changes in the foreign currency value of government revenues owing to changes in the real exchange rate. The other reason for shunning foreign currency debt is the governments' limited ability to generate foreign currency revenues.

In his comments on the paper, Jorion outlines alternative theoretical models of asset and liability management to that proposed by Dooley, each of which implies a different conclusion regarding debt management policy. For instance, he argues that governments should issue long-term domestic debt when real shocks are important, but when monetary shocks dominate, such strategy would not be optimal. In alternative situations, if the government's antiinflation stance is not credible, the private sector may increase the price of debt if it expects the government to inflate its debt away. In these circumstances, issuing floating rate debt or foreign currency debt may be preferable from the sovereign's viewpoint.

Following on Dooley's paper, de Fonteray and Jorion provide a comprehensive survey of various approaches to sovereign debt management, focusing on the optimal size of foreign currency debt for a country (if any) and the optimal composition of sovereign debt. In contrast to Dooley, the authors reach the conclusion that the sole issuance of domestic currency debt is not necessarily the optimal strategy for the sovereign. Indeed, developing countries should diversify the currency composition of their external debt to reduce the risks associated with the impact of interest rate and exchange rate changes on their ability to meet their external debt obligations. They also argue that the issuance of foreign currencydenominated debt can give the government's anti-inflation program credibility as it provides a signal that the authorities will not attempt to reduce the value of their debt through inflation. Taking Australia as a case study, the authors demonstrate how modern portfolio the-

\section{CInternational Monetary Fund. Not for Redistribution}


ory can be applied to generate an optimal currency composition for the Australian portfolio that is consistent with the authorities' objectives as well as projections of market developments.

In his comments on the paper, Makoff points to the sensitivity of the results of the analytical framework chosen to the choice of inputs, that is, historical or projected risk/return parameters. He suggests that caution should be exercised in applying portfolio theory; that the conclusions should be tested under a wide range of assumptions; and that significant constraints should be imposed to guarantee sufficient diversification and to enforce consistency with other portf olio objectives.

The second part of the conference volume focuses on the experience of various countries in managing their sovereign assets and liabilities. Sullivan opens the discussion. outlining both the institutional approach to debt management in Ireland and the main objectives and constraints facing policymakers. In Ireland, the National Treasury Management Agency was established in 1990 in response to a rapidly growing and increasingly complex debt position. According to Sullivan, the National Treasury Management Agency's principal objectives are to manage the debt in such a way as to protect both short-term and longer-term liquidity; contain the level and volatility of annual fiscal debt-service costs: reduce the Exchequer's exposure to risk; and outperform a benchmark or shadow portfolio. To achieve the desired fixed/floating mix and the targeted maturity structure of its foreign currency liability portfolio, the National Treasury Management Agency uses actively derivative markets. in vien: of Ireland's debt dynamics and the decline in domestic interest rates over the past few years, the National Treasury Management Agency has reduced the foreign currency component of its sovereign debt, issuing primarily longer-term fixed rate domestic currency debt.

Radstam highlights the approach of the Swedish National Debt Office to debt management. The Swedish National Debt Office's objective is to minimize the long-term cost of the foreign currency debt within the risk limits established by the Board of the Swedish $\mathrm{Na}$ tional Debt Office. With a foreign currency debt portfolio of over $\$ 60$ billion, the Swedish National Debt Office is one of the largest borrowers in international markets. The currency composition of the benchmark has been chosen to reflect the prevailing currency regime in Sweden. In terms of the fixed/floating split, half of the debt is at floating rates and the other half at fixed rates with matu- 
rities of one, three, five, seven, and ten years in equal proportions. While the aim of the Swedish National Debt Office's benchmark is to ensure an average outcome in terms of cost, the agency is allowed to take currency and interest rate positions relative to the benchmark within risk limits laid down by the board. Indeed. during the past five years. the active management of the foreign currency debt has resulted in savings of over SKr 11 billion.

Wheeler then examines New Zealand's experience and ongoing innovation with sovereign debt management. The New Zealand Debt Management Office's objective is "to identify a low risk portfolio of net liabilities consistent with the Government's aversion to risk. . and to transact in an efficient manner to achieve and maintain that portfolio." Wheeler outlines ways in which New Zealand's implementation of debt policy has been upgraded over the years. In particular, he notes that New Zealand has reconfigured its debt portfolio to remove foreign currency exposures and achieve a longer duration of NZ-dollar debt, including inflation-indexed securities.

Against the background of trends in Belgian public indebtedness and the reform of Belgian capital markets in the early 1990s, de Montpellier discusses the development of the Belgian Treasurys methodology of establishing a debt postfolio structure. Such a structure is defined as one that best minimizes the financial cost of the public debt within acceptable risk levels, while taking account of the macroeconomic objectives of the policymaker (budgetary and monetary policies). Indeed, in addition to the financial risks (market risk, credit risk, and operational risk) that any market participant is subject to, the manager of public debt has to be aware of the "macroeconomic" risks facing the policymaker. De Montpellier argues in favor of managing public debt separately from foreign assets, as the cash flows on the asset side of the state's balance sheet are not as sensitive to financial variables as are those on the debt side.

The papers presented by both Nitugee and Rigaudy' revien trends in central bank reserve management in recent years. Based on an adherence to the balance sheet approach, Nugée argues in favor of managing sovereign assets and liabilities jointly, even if this entails identifying a common objective that does not interfere with the separate objectives of the central bank and the Ministry of Finance. He argues that from a national perspective. risks inherent in holding foreign currency reserves are best managed when aggregated at the 
highest level possible. If risks are too disaggregated, then control is sacrificed and the accumulation of a large number of small risks can become an unacceptable large risk. Nugée points out that by focusing on net reserves or liabilities, the sovereign can direct its attention more effectively to the part of its balance sheet at risk.

Rigaudy also identifies a number of significant changes that have taken place with regard to the objectives and investment policies of central banks. He notes that although the size of foreign reserves has increased substantially, the currency composition of reserves has remained stable. He argues that despite a large literature on the optimal level of reserves, the size of reserves in most countries is a consequence of economic policy, particularly monetary policy, rather than an objective per se. However, while liquidity remains the central issue for foreign exchange management, return maxinization has become a more important concern. Rigaudy also discusses a number of thorny issues in reserve management, such as the management of gold reserves, the increased mobility of capital, and the difficulties of managing market activities in public institutions.

The next two papers present a practical experience of Australia's and Denmark's reserve management approaches. Battellino describes Australia's reserve management process, highlighting that reserves are primarily held to fund foreign exchange intervention with the purpose of moderating movements in the exchange rate in times of volatility. To this end, the Australian benchmark includes the three major reserve currencies (the U.S. dollar, the deutsche mark, and the Japanese yen) in roughly equal proportions, as the yen and deutsche mark display a strong negative covariance with the Australian dollar, while the latter is closely linked to the U.S. dollar. Battellino notes that the central bank has chosen a benchmark duration of 30 months because once the duration moves out beyond two and a half years, the risks of negative returns increase substantially. While the investment committee of the central bank is given considerable discretion in managing the reserve portfolio, the performance of the portfolio is carefully monitored: the portfolio is marked to market daily and reported to the Governors quarterly and to the public annually.

In contrast to Australia, Hansen explains that the Kingdom of Denmark manages its foreign debt and foreign exchange reserves within a coordinated framework focusing on the net foreign debt. The net debt is managed via the setting of a benchmark portfolio 
consisting of assets or liabilities in U.S. dollars, ERM currencies, Japanese yen, sterling, and Swiss francs, the distribution of which is decided by the Ministry of Finance and the central bank on a quarterly basis. Interest rate risk is managed by ensuring that the sovereign foreign assets and liabilities have a short duration, so that neither the interest rate risk of the government or central bank nor the combined risk of the two institutions is affected significantly by government borrowing to finance currency intervention.

Pilato exposes the risks that arise when lower-credit sovereign borrowers swap out of debt issued in foreign currencies back in their domestic currency to eliminate market risk and take advantage of arbitrage opportunities. He argues that the use of swaps constrain the borrowing capacity of lower-credit sovereigns by utilizing their credit lines with banks and expose them to higher counterparty risk as they often have to deal with lower-credit swap counterparties. Pilato describes an approach to measure the "cost" of swap counterparty credit risk based on the most likely or expected exposure and funding spreads. To consider this issue, he derives a debt optimization framework that takes into account borrowing capacity risk in addition to the conventional measures of risk-cost and volatility of cost. The optimal solution derived by the model is shown to be different from that derived by the usual optimization framework.

The last part of the conference volume turns to a discussion of private sector experiences with sovereign asset and liability management. Klaffly, Glenister, and Otterman discuss risk management and its application to central banks. After identifying several types of risk-market risk, credit risk, liquidity risk, legal risk, and operations risk-that confront central bankers, the paper describes the quantification of portfolio market risk and the role of a benchmark in the investment strategy. The authors especially focus on how risk should be managed in an institutional setting, discussing the types of checks and balances that should be established to facilitate the monitoring and improvement of the risk management process.

In the final paper of the volume, Hakanoglu discusses the methodology used in the Goldman Sachs Asset-Liability Management Model to determine the optimal maturity profile and currency composition of a sovereign debt portfolio. Hakanoglu first highlights the simulations (Monte Carlo) used to construct an optimal portfolio, then discusses the various issues involved in measuring the risk tolerance of the client, and finally demonstrates the con- 
struction of an optimal portfolio to reflect such risk tolerance. The paper explains how a benchmark portfolio can be derived and stresses that a benchmark should represent a minimum risk position for the sovereign that takes into account various market exposures and the long-term objectives and constraints under which the sovereign is operating. Typically, a benchmark would approximate the desired long-term portfolio of the sovereign, and would be used to measure the performance of the actual sovereign portfolio. 


\title{
Management of Sovereign Assets and Liabilities
}

\author{
Marcel Cassard and David Folkerts-Landau
}

$\mathrm{M}$

any emerging market countries have gained greater access to lexternal sources of finance in recent years, and this in turn has increased their exposure to volatility in international asset prices. Indeed, developing country sovereign entities are often especially exposed to international disturbances, because of their large stock of foreign currency liabilities (relative to national income) and the relatively risky structure of their debt portfolios (by currency composition and maturity profile). What this means in practice, in a sometimes volatile international financial environment, is that the benefits of prudent macroeconomic management and structural reforms are all too often severely compromised by unexpected changes in foreign interest rates and exchange rates.

Major multinational firms (both financial and nonfinancial) have adapted to the volatility of financial markets through the use of hedging techniques and derivative instruments to manage their risk exposures. This approach has been facilitated by important advances in financial technology in the past decade, and by specialized risk management techniques developed by institutional fund managers. In contrast, many sovereign entities-some of them major players in international financial markets with large financia! assets and liabilities - have mostly lagged behind the private sector in this respect. The recent experience of a small, but growing, number of countries that have reformed the management of sovereign assets and liabilities demonstrates that sound risk management can lessen the impact of external financial developments on national 
wealth, and potentially increase returns on foreign reserves and reduce borrowing costs.

The current literature on risk management is rich in its treatment of portfolio allocation problems, but it provides little guidance for sovereigns on how to manage the risk exposure of their assets and liabilities. By drawing on the experience and the well-established methodologies of large institutional investors and pension funds, and on the experience of sovereigns that have reformed their debt management policies, this chapter examines (1) the risks involved for a government in carrying a large open foreign currency exposure; (2) the design of institutional arrangements that provide appropriate incentive structures for debt and reserves management; and (3) the establishment of benchmark portfolios embodying the preferences of the policymaker for incurring currency, interest rate, and credit risks, as well as reflecting the macroeconomic and institutional constraints of the country. These issues raise thorny questions about the optimal currency exposure of a sovereign; the extent of interaction between debt management policy, reserves management, and monetary policy; the degree of independence of debt management from political oversight; and the extent to which reserves management should be under public scrutiny. Although this chapter primarily targets emerging market economies and small industrial countries, which are more vulnerable to swings in foreign currencies and interest rates, the framework discussed is applicable to most countries.

\section{Foreign Currency Exposure of Sovereign Liabilities}

The external exposure of developing countries' sovereign liabilities has increased steadily during the past two decades, from 7 percent of GDP in 1975 to about 30 percent of GDP in the mid-1990s (Figure 2.1). In 1995, the external debt held or guaranteed by developing country sovereigns was almost three times larger than their foreign currency reserves, exposing governments to a large net currency risk exposure (Table 2.1). External debt also exposed developing countries to foreign interest rate risk. Indeed, about half of developing countries' external debt in 1995 was exposed to foreign interest rate risk, as 20 percent of the external debt was short term (under a one-year maturity), and 40 percent of the remaining long- 
Figure 2.1. External Long-Term Public and Publicly Guaranteed Debt Outstanding

(In percent of GNP)

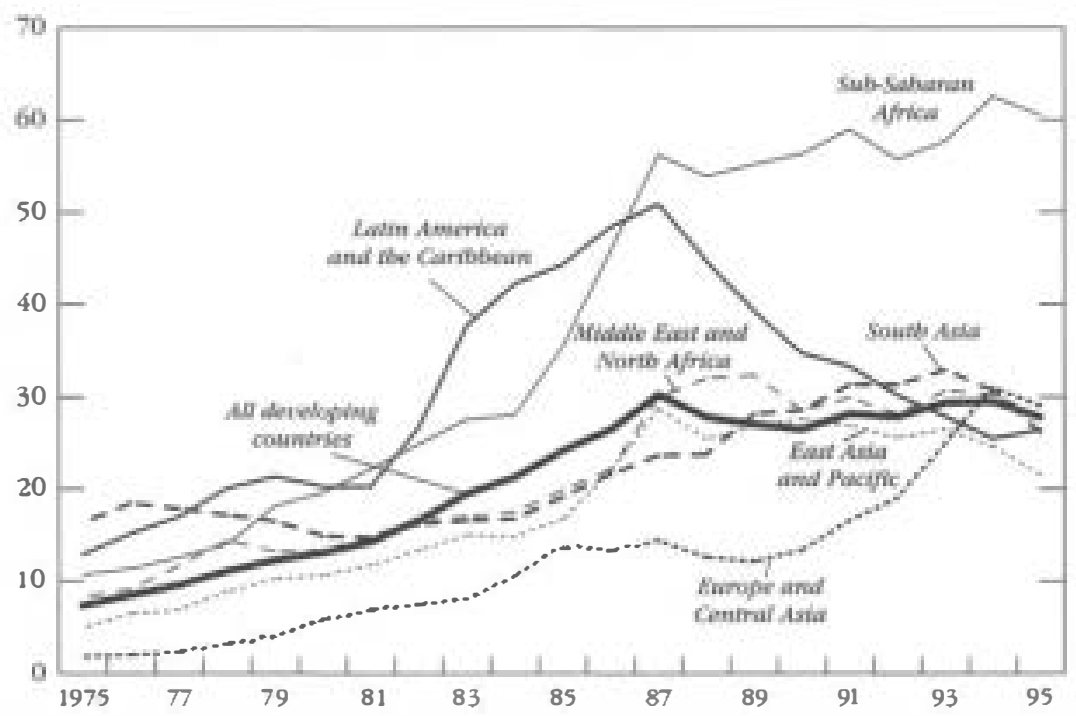

Source: World Bank, Global Development Finance dawbase. Note: The groupings are as shown in the source.

term debt was at floating rates (mostly indexed to LIBOR-- the London Interbank Offered Rate).

Several developing countries have experienced the impact of adverse movements in foreign currencies and interest rates in the past 20 years. In the early 1980s, the debt-servicing burdens of countries in Southeast Asia, Latin America, and Africa were severely affected by the steep appreciation of the doliar, the worldwide increase in interest rates, and the sharp decline in commodity prices. The debt crisis resulted in output and employment losses, financial sector crises, and the exclusion of these countries from international financial markets, which was only regained in the early 1990 s.

In the first half of this decade, several Asian countries that had overcome the 1980s debt crisis because of their prudent fiscal policies experienced significant increases in their debt burden owing to their exposure to the Japanese yen. Between 1980 and 1994, East Asian and Pacific countries increased their borrowing in Japanese yen from below 19 percent to 30 percent. Although the increase in 
Table 2.1. Long-Term Public and Publicly Guaranteed External Debt Outstanding and Reserves Excluding Gold in Selected Developing Countries, 1995

(In billions of U.S dollars)

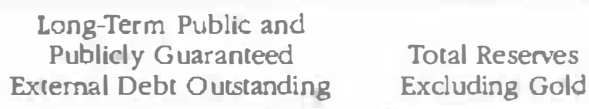

Total Reserves Excluding Gold

Asia

China

India

Indonesia

Malaysia

Philippines

Thailand

Europe

Czech Republic

Hungaty

Poland

Russia

Turkey

Western Hemisphere

Argentina

Brazil

Colombia

Mexico

Venezuela

Memorandum item:

All developing countries ${ }^{1}$
94.7

79.7

65.3

15.9

29.9

17.2

23.6

41.1

100.3

50.1

62.2

96.6

13.0

94.0

28.5

Sources: Internamional Monewy Fund, International Financial Statistics (June 1997); and World Bank. Globwl Derelopment Finance, 1997.

IWorld Bank data. Intemational reserves include the country authorities' holding of SDRs, the reserve position in the LMF, foreign exchange holdings, and gold.

yen-denominated borrowing was due partly to large concessional loans from Japan to Asian countries, and the growing role of the yen in international trade and finance, it also reflected the desire of Asian borrowers to benefit from low interest rates on yen loans compared to U.S. dollar loans. Most of the countries did not hedge their yen exposure either in local currency or in the U.S. dollar, which accounts for a large part of their foreign currency revenues. As a result, the appreciation of the yen against the dollar and the Asian currencies in the 1990 s led to a significant increase in the dollar value of their external liabilities (Table 2.2). The share of yendenominated debt in total debt was subsequently reduced to 27 per- 


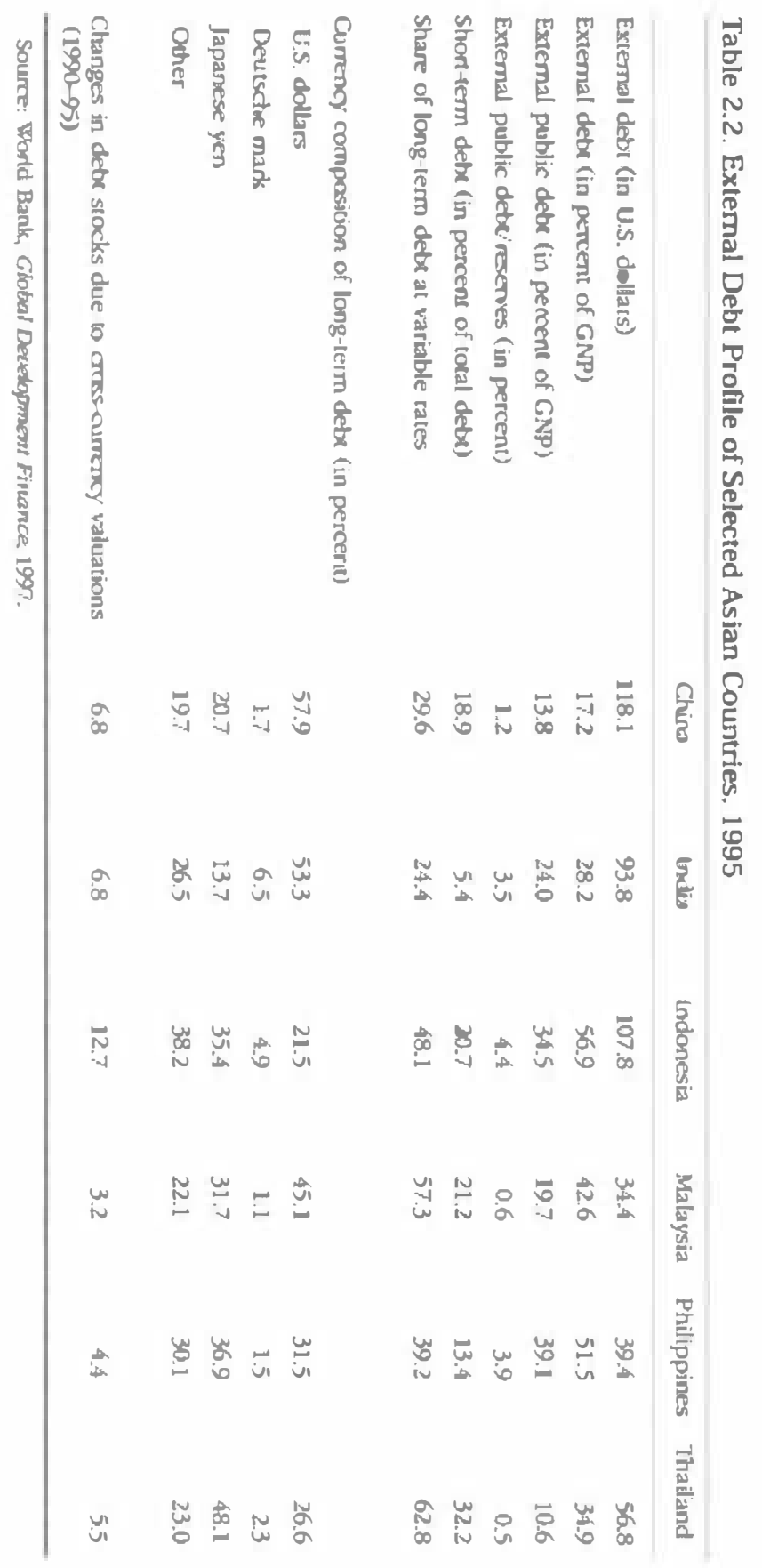


cent in 1995, and the share of yen-denominated foreign reserves increased.

In Indonesia, for example, one-third of the increase in the dollar value of the external debt between 1993 and 1995 was due to crosscurrency movements, primarily the appreciation of the yen. Indonesia's exposure to the yen has been especially costly, as about 90 percent of its export revenues were denominated in dollars, while 37 percent of its external debt was denominated in yen. In the Philippines, which has one-third of its external debt denominated in yen, the appreciation of the yen accounted for about one-half of the increase in the dollar value of the external debt in 1995. In China, the appreciation of the yen is estimated to have increased the servicing costs of the public debt by about $\$ 5$ billion. In Malaysia, the sharp appreciation of the yen in 1994 increased the dollar value of the external debt by 6 percent. In India, the external debt increased by almost 7 percent in 1995, almost exclusively on account of exchange rate changes. ${ }^{1}$ The subsequent depreciation of the yen in 1996 offset some of the losses incurred by these countries.

The degree of vulnerability of developing countries to external shocks is largely a function of the maturity profile of their foreign currency debt. Events in Mexico during 1994-95 illustrate how reliance on short-term foreign currency can make a country vulnerable to liquidity crises, as the need to refinance a substantial volume of short-term debt in turbulent foreign exchange markets creates additional market pressure. ${ }^{2}$ One of the lessons of the Mexican experience is that the external risk exposure of the government (in terms of currency composition, maturity profile, share of floating rate debt, and concentration of maturities) is equally indicative of its vulnerability to external shocks as its debt leverage. Indeed, the Mexican crisis was partly attributable to financial markets' concerns about the currency composition and maturity of the public debt and not by its actual level, which was relatively low by Organization for Economic Cooperation and Development (OECD) standards-

\footnotetext{
${ }^{1}$ Changes in external debt are measured in dollar terms, as the latter is the main trade or invoice currency for Asian developing countries. The dollar is also the main currency against which Asian domestic currencies are managed (e.g., Indonesia, the Philippines, and Thailand).

2See Folkerts-Iandau and Ito (1995) for a discussion of the role of short-term foreign currency debt in the Mexican crisis.
} 
51 percent compared with an OECD average of 71 percent (Calvo and Goldstein, 1995). The vulnerability of the Mexican economy to a financial crisis was exacerbated by the $\$ 29$ billion of tesobonos maturing in 1995 , with about $\$ 10$ billion maturing in the first quarter, in light of the low level of foreign reserves ( $\$ 6.3$ billion) at the end of 1994. Had the maturity of the tesobonos been longer and not bunched in the same quarter, the exchange rate crisis may not have turned into a debt-servicing crisis.

The large stock of foreign currency debt held by developing countries is a consequence of several historical and structural factors, including low domestic saving rates relative to domestic investment, a lack of domestic borrowing instruments, and reliance on official financing (multilateral and bilateral), which tends to be denominated in donor countries' currencies. Foreign currency debt has also been issued to signal the government's commitment to a policy of stable exchange rates or prices. In a game-theoretic framework, policymakers can signal the time-consistency and credibility of their policies to the public by raising the cost of reneging on their commitments.

More recently, as emerging markets have regained access to international debt markets, the choice of currencies and the maturity structure of their foreign currency borrowing has been often driven by the lower risk premiums and coupon rates, and the corresponding initial budget savings. ${ }^{3}$ Such debt strategies may be underestimating the risks associated with unhedged foreign currency borrowing for several reasons.

First, the capacity of governments to generate foreign currency revenues to repay their obligations is generally limited, as government assets are predominantly the discounted value of future taxes denominated in the local currency. Second, it is unlikely that the output, welfare, and reputational costs that a developing country may suffer in the event of an adverse external shock are fully taken

3Several emerging market governments (e.g.. Argentina, Colombia, Hungary, Mexico, and Turkey) have issued debt denominated in yen or deutsche mark in the past few years, without having a significant exposure to those currencies on the revenue side. Following the negative impact of the yen's appreciation in 1994-95, a few of these countries (Colombia, Hungary, and Mexico) began reducing or hedging their yen exposure. 
into account in emerging markets' external borrowing strategies. Although the probability of a crisis may appear to be low, the potential disruptions to the economy can be substantial. Indeed, a net foreign exchange exposure exacerbates the impact of external shocks on the economy, and limits the policy options of the authorities during a financial crisis. A sovereign with a large net foreign currency exposure would have difficulty pursuing an expansionary monetary policy during a financial crisis, to reflate the economy, as it may cause a sharp decline in the exchange rate. A depreciation of the exchange rate would worsen the country's indebtedness and risk profile, and magnify, rather than dampen, the financial crisis (Mishkin, 1996). In the event of an adverse real exchange rate shock, a government may also face the dual cost of an increasing external debt-servicing cost and a declining foreign currency value of its revenues (Dooley, 1997). In addition to the potential capital losses that a government may incur on its debt portfolio, its ability to access international markets to refinance its maturing debt is likely to be hindered.

Furthermore, the lower cost of foreign currency debt relative to domestic currency debt does not reflect just the creditworthiness of sovereign borrowers, but also the presumption on the part of external creditors that their claims would have implicit seniority over domestic claims. Such implicit seniority arises from a covenant structure (such as cross-default and pari passu clauses), which allows for extensive legal recourse on the part of the external creditor. For example, cross-default clauses covering a wide array of lenders and instruments may deny the sovereign borrower the possibility of restructuring only a narrow but particularly pressing instrument, such as short-term note obligations falling due, without precipitating an advancing of the due dates of most other short- and long-term issues. Similarly, pari passu clauses make it difficult for sovereign borrowers to negotiate a bond restructuring unless the great majority, if not all, of bond holders are included. In the absence of an agreement, creditors also have extensive rights under existing statutes to seek legal recourse in the relevant jurisdictions. Such recourse could result in a significant impairment of trade and financial flows involving the debtor countries, as well as impairment of its external debt. It is unlikely that the costs of the macroeconomic adjustment needed to prevent an interruption in servicing external debt under such circumstances are fully taken into consider- 
ation by a government when deciding on the size of its external exposure.

Third, there is no conclusive empirical evidence that the diversification benefits of unhedged foreign currency borrowing outweigh the added risk from the effect of nominal and real exchange rate fluctuations on the debt portfolio. ${ }^{4}$ In contrast, there are numerous studies of internationally diversified portfolios that show that investors can lower their risks without significant changes in returns by completely hedging their exposure to exchange rate movements - that is, purchasing power and interest rate parities do not hold.' During the 1980s, irrespective of investors' base currencies, the returns on currency-hedged foreign bond portfolios were less volatile than the returns on unhedged portfolios. Although such studies apply to portfolios held by institutional investors, sovereign entities are unlikely to predict the direction of exchange rates more accurately than they do.

In view of the risks associated with large open foreign currency exposures, as well as the existence of deep and liquid domestic capital markets, the governments of most industrial countries have limited their issuance of foreign currency debt (Table 2.3). Among large advanced economies, Germany, Japan, and the United States do not issue foreign currency debt, while France and the United Kingdom only issue a small fraction of their debt in ECUs. In Canada, foreign currency debt represents about 3 percent of total public debt (reflecting debt accumulated in the past and debt issued to finance foreign reserves), and the budget deficit is funded entirely in domestic currency. In recent years, a number of small advanced economies, including Belgium, Denmark, and New Zealand, have stopped issuing foreign currency debt, except for replenishing their foreign reserves. In Ireland, gross foreign currency borrowing is limited to the level of maturing foreign currency debt. Spain and Sweden issue foreign currency debt, but hedge their currency risk through swaps or swap options (also known as swaptions).

${ }^{4}$ The overall risk of the portfolio may be reduced if the domestic currency cost of domestic debt is negatively correlated with the domestic currency cost of foreign currency debt.

5See, for instance, Perold and Schulman (1988); Eaker, Grant, and Woodard (1993); Glen and Jorion (1993); and Kritzman (1993). 
Table 2.3. European Union Countries, North America, and Japan: Foreign Currency Debt, 1996

\begin{tabular}{lcc}
\hline Country & Foreign Currency Debt & Year $^{\mathbf{l}}$ \\
\hline European Union countries & & \\
Austria & 17.50 & 1996 \\
Belgium & 11.40 & 1995 \\
Denmark & 14.30 & 1996 \\
Finland & 42.92 & $1996^{2}$ \\
France & 4.80 & 1995 \\
Germany & 0.01 & 1995 \\
Greece & 30.60 & 1996 \\
Ireland & 26.40 & 1996 \\
Italy & 6.10 & 1996 \\
Luxembourg & 3.50 & 1995 \\
Netherlands & 0.00 & 1996 \\
Portugal & 17.70 & 1996 \\
Spain & 7.30 & 1996 \\
Sweden & 28.20 & 1996 \\
United Kingdom & 4.60 & 1996 \\
& & \\
North America & & 19963 \\
Canada & 2.64 & 1996 \\
Mexico & 8.00 & 1996 \\
United States & 0.00 & 1996 \\
Japan & &
\end{tabular}

Source: International Monetary Fund.

'The years for which the latest data are avajlable.

2For central government.

.Data as of March 31, 1997, for the federal government.

In developing countries, however, governments of ten need to access international debt markets to offset a shortage of local savings, lengthen the maturity of their debt, diversify their interest rate risk exposure across various asset markets, accumulate foreign exchange reserves, or develop benchmark instruments enabling domestic private entities to issue abroad. When derivative markets (such as forwards, futures, swaps, and options) in the domestic currency are available, governments can immediately hedge their foreign currency borrowing, thereby limiting their exposure to foreign exchange and interest rate movements. The foreign currency can be hedged into the domestic currency, or, when difficult, into a currency closely correlated to the domestic currency that has liquid derivative markets. Issuing currency-hedged foreign debt would preclude a borrowing strategy solely targeted at reducing interest rate costs and softening internal budget constraints. 
Almost all industrial countries and many emerging markets have access to derivative instruments to hedge their foreign exchange risk. Several emerging markets, including Brazil, Chile, Indonesia, Malaysia, and Thailand, have currency swap markets with maturities of up to five or 10 years. In other emerging markets (such as Mexico, the Philippines, South Korea, and Taiwan Province of China), forward markets - the embryos of swap markets-are rapidly developing. ${ }^{6}$ The increasing sophistication of international derivative instruments also has expanded considerably the ability of governments to respond to opportunities to exploit market niches and expand their investor base-for example, to include Japanese or German retail investors-without bearing the yen/dollar exchange rate risk. Furthermore, World Bank borrowers may use a recently established scheme to improve the management of the currency and interest rate risks of their World Bank loans. Under the new World Bank scheme, borrowers can amend the terms of their existing currency pool loans-currency composition and floating rate/fixed rate mix - to reflect their desired debt management strategy (World Bank, 1996a). ${ }^{7}$ The scheme would allow eligible countries to restructure their external debt without using their swap credit lines with commercial banks, and at low transaction costs.

Reducing the currency risk exposure of emerging markets' sovereign debt and lengthening its maturity profile is a medium-term strategy and a gradual process, and is contingent on the development of domestic capital markets and of hedging instruments denominated in the local currency. During the transition, the government should manage its net foreign currency risk exposure effectively, so that its vulnerability to exchange rate and foreign interest rate fluctuations is bounded.

'The ability of governments to swap their foreign currency debt may also be constrained by their credit line limits with financial institutions, as swap ransactions reduce such credit lines.

${ }^{7}$ Currency pool loans are multicurrency obligations, with the U.S. dollar, deutsche mark, and Japanese yen accounting for at least 90 percent of the dollar value of the currency pool. The currencies are targeted until 2001 in fixed currency ratios of 1 dollar for every 125 yen and 2 deutsche mark equivalent. All currency pool loans are made at a variable rate reflecting World Bank cost of funding. 


\section{Institutional Arrangement for Management of Sovereign Liabilities}

Efficient management of the external risk exposure of sovereign liabilities requires institutional arrangements that provide appropriate incentive structures for debt management, technical expertise and sophisticated information systems, and strict internal management procedures. In many developing countries, it is still difficult to create such incentive structures, attract qualified staff, acquire the technical expertise and systems, and develop the controls necessary to manage effectively the overall sovereign risk exposure.

Furthermore, in several developing countries, debt management policies lack transparency and accountability, and are not guided by risk management practices. The lack of transparency and accountability allows debt managers to compromise the country's debt profile for short-term political gains, by, for instance, issuing short-term debt solely because it demands lower interest rates or borrowing in foreign currencies with low interest rates. ${ }^{8}$ Although the budgetary costs can be reduced by these actions, the economic cost can be much higher and the sovereign's risk profile can be significantly worsened. An opaque institutional structure allows a policymaker with a short horizon to manipulate the structure of the public debt to its own benefit, as the economic and political gains are immediate, while the potential costs (higher refinancing costs and higher expenditures) are transferred to the future. Investors' expectations that the risk of higher refinancing costs may lead to higher taxes or default rates, however, translate into a higher risk premium on the government debt.

The lack of transparency in debt management is further exacerbated by the fact that debt management is often not centralized within a single institution, as state, provincial, or local governments or parastatal institutions are involved in debt issuance. In addition to confusing the decision-making process and subjecting debt management to potential political pressures, such dispersion induces haphazard and uncoordinated borrowing, and hence an inefficient debt structure. Moreover, the exposure of the public debt to financial risks

BDomestic debt mismanagement (excessive concentration of debt in shortterm maturities, illiquid and costly debt issuance techniques, bunching of maturities) is also widespread in a number of countries. 
is unlikely to be assessed and hedged accurately under such a dispersed structure, thereby increasing its vulnerability to shocks.

Since the early 1990s, there has been a heightened awareness among governments of the importance of sovereign debt management, particularly in an environment of increasingly mobile and volatile capital flows and integrated international capital markets. Several OECD countries and some emerging markets have undertaken ambitious reform efforts. Several principles emerge from their experiences. First, to preserve the integrity and independence of the central bank, it is preferable to separate debt management policy from monetary policy. Second, it is desirable to shield debt management policy from political interference to ensure transparency and accountability in its conduct. Third, debt management could be significantly improved if it was entrusted to portfolio managers with knowledge and experience in modern risk management techniques, and if their performance was measured against a set of criteria defined by the Ministry of Finance. Finally, it is important to allocate sufficient resources for hiring high-quality staff and to acquiring sophisticated systems to support the staff.

\section{Separating Debt Management From Monetary Policy}

In contrast to the integrated management of assets and liabilities by corporations, which manage financial risks by matching the currency composition and maturity of their assets with those of their liabilities, the management of sovereign assets and liabilities is usually not commingled. In the majority of countries, central banks are in operational charge of reserves management, while Ministries of Finance maintain operational authority over liabilities management. Such separation of responsibilities in managing sovereign assets and liabilities is viewed as optimal by governments because of the potential conflicts of interest between monetary policy and debt management, which may compromise the independence of the central bank. A central bank with a dual mandate for conducting monetary policy and debt management policy, for instance. may be reluctant to raise interest rates to control inflationary pressures, as this would have an adverse effect on its domestic liability portfolio. A central bank may also be tempted to manipulate financial markets to reduce the interest rates at which government debt is issued or to inflate away some of the value of nominal debt. In other circum-

\section{(C) International Monetary Fund. Not for Redistribution}


stances, a central bank may be tempted to inject liquidity in the market prior to debt refmancing, or to bias the maturity structure of the debt profile according to the stance of its monetary policy.

Conflicts of interest between debt policy and monetary policy may also arise if the central bank is in charge of managing the foreign currency debt portfolio of the government. For instance, the daily management of the liquidity of the foreign currency debt in the foreign exchange market---converting foreign bond proceeds into local currency, or converting local currency funds for foreign currency debt repayments--may conflict with the intervention policy of the central bank. The central bank's sales and purchases of securities to meet foreign currency debt requirements also could be perceived by financial markets as having a signaling effect on its exchange rate policy, thereby undermining its effectiveness.

Although separating debt policy from monetary policy is desirable to support the integrity of the central bank, only close coordination between the Ministry of Finance and the central bank will ensure that debt management policy is consistent with monetary policy. Without proper coordination, the participation of the Treasury in the foreign exchange market may have significant monetary implications, and may be at odds with the intervention policy of the central bank. Specifically, the central bank needs to be fully informed of the daily transactions of the agency in charge of debt management, so that it can adjust its day-to-day management of liquidity and intervention policies to offset the impact of these transactions on the market. This is particularly the case when the central bank has to meet the foreign currency needs of the Treasury, such as exchanging the foreign currency proceeds of an external bond issue to local currency, or converting local currency funds into foreign currency for interest or principal repayments on the foreign currency debt. Full cooperation between the two institutions also requires the central bank to inform the debt manager of the composition and maturity of its reserves portfolio and update it on a regular basis, so that the debt manager can take it into account in its debt management policy.

Potential conflicts of interest between monetary policy and debt policy have induced several countries to separate the two functions. In New Zealand, all debt management functions carried out by the central bank, as agent of the debt office, have been conducted without reference to monetary policy considerations since 1988. The 
New Zealand debt office makes all pricing decisions on treasury bills and government bonds, and advises the Minister of Finance on the size and structure of the domestic borrowing program. The foreign reserves of the central bank are integrated in the debt office's asset and liability management process, however. Specifically, the debt office directly finances the central bank's foreign exchange reserves by maintaining foreign currency deposits at the central bank. Under this structure, the central bank manages its net foreign exchange exposure, while the debt office fully incorporates foreign reserves in its debt management.

In Hungary, the Ministry of Finance took over the cost of servicing the net national foreign currency debt in early 1997 . While the National Bank of Hungary will remain formally responsibie for the interest payments and amortization of the foreign loans issued under its name, it will receive transfers from the Ministry of Finance broadly equivalent to the cost of servicing that part of external debt in excess of the foreign exchange reserves of the central bank at the end of 1996. The Ministry of Finance will take full control of debt management in 1999, and the central bank will act only as the agent of the Ministry of Finance. The shift of responsibilities from the central bank to the Ministry of Finance was deemed necessary to ensure that the monetary policy objectives of the central bank did not interfere with any of its other functions or responsibilities.

In South Africa, the central bank has been until recently the government's agent for marketing its debt instruments, thereby exposing monetary and debt policies to the potential tensions described earlier. After a thorough review of debt policy, the South African authorities set out a new policy framework for debt management in 1996, delegating all policy issues related to state debt management to the Department of Finance. The central bank was made accountable to the Department of Finance on all matters related to debt management, and funding activities undertaken by the central bank on behalf of the government were ring-fenced from monetary policy operations. A high-level body comprising representatives of the Department of Finance and the central bank was also established to coordinate monetary and fiscal policy objectives.

There are instances, however, where the central bank can be in charge of managing the foreign currency government debt and the foreign exchange reserves without creating conflicts of interest. This would apply to a government that issues only foreign currency debt 
to finance foreign reserves. Denmark provides a case in point. The Danish government decided in 1991 to regroup assets and liabilities management under the central bank's authority. The rationale behind the decision was to improve coordination of the management of the public debt and the foreign reserves, and to reduce the net exposure of the government to exchange rate risk." Managing the net exposure of assets and liabilities was deemed to be more appropriate than managing their isolated exposures because of the limited use of the foreign currency debt in funding budget deficits. Indeed, the Danish government issues only foreign currencydenominated debt to replenish foreign reserves when they deviate from a desired level, while only Danish kroner-denominated debt is used to finance the government deficit. Although the central bank is in charge of managing the net portfolio, the decision on the currency composition and the desirable maturity of the net portfolio is taken jointly with the Ministry of Finance and the Ministry of Economic Affairs during quarterly meetings.

In most countries, however, sovereign foreign currency debt is not issued solely to finance foreign reserves, but primarily to finance the fiscal deficit. Under those circumstances, it is preferable to forgo the efficienc'y of a single agency managing the sovereign's net risk exposure to avoid conflict of interests.

\section{Debt Management Framework}

The separation of debt policy from monetary policy allows the central bank to fulfill its monetary objectives unfettered by debt policy objectives. In a similar vein, an efficient, transparent, and accountable debt management policy necessitates an organizational structure independent of political influence, with clearly defined objectives and performance criteria, and run by qualified staff, according to sound risk management principles. A number of countries (such as Austria, Belgium, Ireland, New Zealand, Portugal, and Sweden) have concluded that, to achieve such objectives, debt agencies with some degree of autonomy from the political sphere should be set up. Specifically, the formulation of debt policy (on

While the currency composition of the foreign debt and foreign reserves is matched, there is no immunization of interest risk. 
matters such as level of the debt and limits on domestic and foreign currency borrowing) is a political decision and therefore should rest in the hands of the government. The actual management of the sovereign debt, however, can be extracted from the political domain and assigned to a separate and autonomous debt management office. Under this arrangement, the Ministry of Finance defines the medium-term strategy for debt management-based on its objectives and risk preferences, and the macroeconomic and institutional constraints of the country - while the debt management office implements that strategy and administers the issuance of the domestic and foreign currency debt.

There are several advantages to a separate and autonomous debt management office. First, by recognizing that the structure of the sovereign debt portfolio is an integral part of public policy and deserves a distinct institutional presence, the authorities would signal to financial markets and their political constituency their commitment to a more transparent and accountable debt management policy. Second, an autonomous debt agency can be given a clearly defined objective, based on economic and market-based principles, and organized to achieve such an objective, without being hampered by either the management structure or pay scale of the public sector. In particular, an autonomous debt agency could maintain a flexible management and career path structure, and link the pay scale of its personnel to that of private sector practitioners. Such a flexible pay structure would allow the debt management office to attract highly qualified staff who are knowledgeable about increasingly complex financial instruments and markets. Third, a debt management office perceived by investors as credibly independent from the political decision-making process would contribute to lowering the country's risk premium and the government's borrowing costs, as it would be less likely to engage in risky strategies designed to maximize short-term political gains.

The main task of a debt agency would be to manage the day-today risk exposure (liquidity, market, and credit risks) of the sovereign debt portfolio, and to ensure that the sovereign has continuous and orderly access to international financial markets to meet its external obligations. The debt agency responsibilities also would include managing the domestic public debt portfolio. This entails managing liquidity risk by ensuring that funtre funding needs can always be met at the lowest cost, and are smoothly spread over a 
number of years without significant repayments bunched in single periods. Debt management offices can also enhance the liquidity of the government securities market by increasing the transparency and predictability of debt issuance, and creating liquid benchmark issues spread along the yield curve. ${ }^{10}$ Greater transparency can be attained by planning and reporting in advance the financing requirements of the government, the maturity structure of future borrowing, and the auction dates of domestic debt issuance for the financial year. Greater predictability can be achieved by relying on regular and nondiscretionary debt issuance, primarily through auctions. By increasing liquidity and attracting a larger investor base, the debt management office can contribute to lowering the borrowing costs of the government.

Sovereign risk exposure is not limited to government debt, but includes debt contracted by all public and publicly guaranteed entities (provincial, state or local governments, parastatals, and all other debt with a government's guarantee). Most governments, however, exclude publicly guaranteed debt from their debt management policies until the guarantees are invoked, and hence do not accurately reflect the risk profile of the sovereign. It is therefore desirable that all public debt is centralized under the management structure of the debt management office, and that the risk exposure of the sovereign debt is managed as a single portfolio.

\section{Selected Examples of Debt Management Offices}

Autonomous debt management offices have been established by law in a number of OECD countries, including Austria, Ireland, Portugal. and Sweden (Tables 2.4-2.7). Debt agencies were set up to improve the management of the public debt, by hiring qualified portfolio managers, incorporating modern risk management techniques in debt strategies, and providing a greater incentive for the staff to lower borrowing costs. Although these debt management offices report to the Ministries of Finance, they maintain a significant degree of autonomy from the Ministries of Finance, have their own Board of Directors, follow specific investment guidelines against

\footnotetext{
10When used in the context of domestic debt, a benchmark refers to a large and liquid debt security against which other debt securities (e.g., corporate and state enterprises) are measured and priced.
} 
Table 2.4. Institutional Structure of Debt Offices in OECD Countries: Debt Offices Within the Treasury

\begin{tabular}{|c|c|c|c|c|c|c|}
\hline & & Anserfo & Betgan & Naberlarads & New'Zeabrs & Turkey \\
\hline 1.1 & 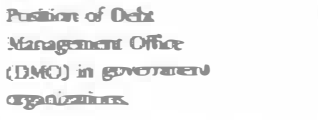 & Branch of Treasun & Tresaury. & Agoro; in Treasfy. & Grabch of the Treasty. & $\begin{array}{l}\text { Centel Direchane in } \\
\text { Trasury }\end{array}$ \\
\hline 12 & $\begin{array}{l}\text { Ohief Exenaive Oficar reports } \\
\text { ore }\end{array}$ & The Treswer & Mlinisory of Farance & Treasure. & Mfisisy of Finare & $\begin{array}{l}\text { The Unifascuerarv and the } \\
\text { tanisut. }\end{array}$ \\
\hline 1.3 & Bcand of Ditecules & No. & No & No. & Advisoey Board & No. \\
\hline 1.4 & 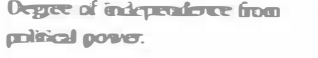 & Highty anterender & Not inderedorl & inforenter & No spoufe indejordere. & $\begin{array}{l}\text { Indeperidern undet morthal } \\
\text { circumstances. }\end{array}$ \\
\hline 21 & 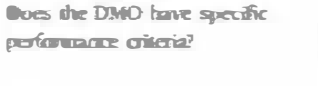 & 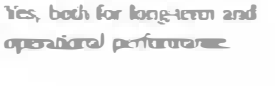 & No specific tribril & $\begin{array}{l}\text { Corenl orienia for } \\
\text { the manminy and } \\
\text { the coss of tontoring. }\end{array}$ & $\begin{array}{l}\text { Qualinative porfunanar } \\
\text { omerio retarmg } 10 \\
\text { all sorios. }\end{array}$ & No \\
\hline 27 & 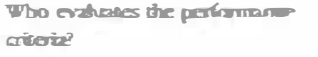 & Dseo. & No specific evatienuon & The Paflismere & Scoctary of Trezan & \\
\hline 2.3 & $\begin{array}{l}\text { Is there a peratry in case } \\
\text { of a loses }\end{array}$ & Na. & Sto. & & & \\
\hline 3.1 & $\begin{array}{l}\text { Is there a kgal fini for domesic } \\
\text { bowosing? }\end{array}$ & $\begin{array}{l}\text { les, firminial yeas } \\
\text { budigenty oed }\end{array}$ & $\begin{array}{l}\text { Limil oe the cost } \\
\text { of borro aung }\end{array}$ & 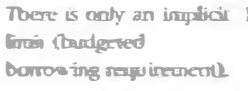 & No legal timin & 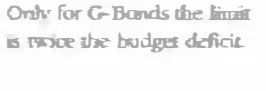 \\
\hline 3.2 & Who decites for the uew linione & DMEO and the Treasure & Nore Pastievene & & 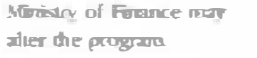 & $\begin{array}{l}\text { For G-foock, abe } \\
\text { Padamen }\end{array}$ \\
\hline 11 & 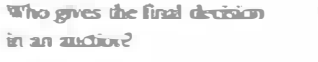 & The Trearoy. & Minisuy of Finare. & $\begin{array}{l}\text { The Agers (chid } \\
\text { exentive of Ditoi. }\end{array}$ & Detw ieragoser Ortace & $\begin{array}{l}\text { The Endrasucher of } \\
\text { Treesury }\end{array}$ \\
\hline s.l & 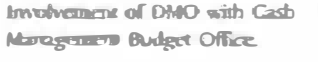 & Orest; r daked & Coxty returat & Oooely retared & $\begin{array}{l}\text { Garied our by Dito } \\
\text { Cosety rabeed }\end{array}$ & Direa trowherbens \\
\hline 6.1 & 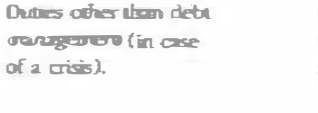 & 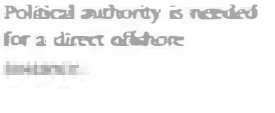 & 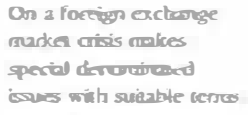 & 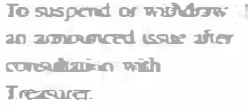 & Wenc: & 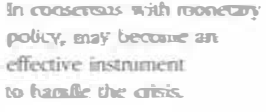 \\
\hline
\end{tabular}


Agracy Services

The aeneral hank

The pare entis

of Ancradis

$$
\text { -.. }
$$
e्यiry, 25 covinl tank saff
Eqperisdent to civil servant. Fqquivalere to civil lower than banks (privase).

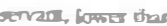

tranks (grime).

The Narizeal Bant of
Betgim and firmencial

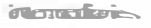

Colecting the comms

and ditheing the

Treasiry accrement

Al Treasy cenificas and part of oches pubtic

Inanx

Fre Treasury offued for bootfor all areas of ropisory.

Al Treagy revificas and part of other public kears ( $T$ presers)

Deber aranagmest tyanch of the Treasingy.

Pable Doch Ofice in the Treasery.

Firancial repocting

and cuelupase

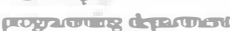

of the ageosy.

Cast and aconal basis.
Casto tanis for Budpo Accuras Acurad basis for Fenancial SQmergeres

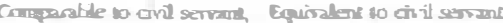

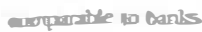
loser than berlas (privite)

\section{The Anging} plecerve Bunt of

New Zeakand.

\section{The ceneal lank.}

Handing the Jurouns selling toonds on TAP. redenyptiors and irseres paryveres. and kexping ocpmial accoures.

0

100 percers.

20 Treasy ofture:

29 stert.

Risger and Dursaic Depe Tres isions in Treasy.

Casto sorual and mark-to moricer bacis

Eadi bacs for the thulgeren? popares ancival tasis for following up the socic

Source: Organizakion for Economic Cooperalion and Developmemt (OECD). 
Table 2.5. Institutional Structure of Debt Offices in OECD Countries: Autonomous Debt Offices

\begin{tabular}{|c|c|c|c|c|}
\hline & & Ausria & lseland & Sweden \\
\hline 1.1 & $\begin{array}{l}\text { Position of Debi Management } \\
\text { Office (DMO) in Gosermment } \\
\text { Organizations. }\end{array}$ & $\begin{array}{l}\text { Autonomous Corporate Boty } \\
\text { owned by Mlinisty of } \\
\text { Finance (AFFA). }\end{array}$ & $\begin{array}{l}\text { Autonomous Agency under } \\
\text { the Minisury of Finance. }\end{array}$ & $\begin{array}{l}\text { Autonomous Agency undet the } \\
\text { Ministy of Finance }\end{array}$ \\
\hline 1.2 & Chief Execulive Officer repors to: & Minisuy of Finance. & Minisiry of Finance. & \\
\hline 1.3 & Board of Directors. & Yes. & Advisory Committee. & Yes \\
\hline 1.4 & $\begin{array}{l}\text { Degree of independence from } \\
\text { political power. }\end{array}$ & Highly independeni. & $\begin{array}{l}\text { Independent in some broad } \\
\text { guidelines drawn by } \\
\text { Ministy of Finance. }\end{array}$ & $\begin{array}{l}\text { Independent, except for a few } \\
\text { issues (foreign exchange). }\end{array}$ \\
\hline 2.1 & $\begin{array}{l}\text { Does the DNO have a specific } \\
\text { performance criteria? }\end{array}$ & No specific criteria. & Yes. & $\begin{array}{l}\text { For foreign exchange } \\
\text { funding and donestic funding. }\end{array}$ \\
\hline 2.2 & $\begin{array}{l}\text { Who evaluates the } \\
\text { perfomuance criteria? }\end{array}$ & & $\begin{array}{l}\text { I.P. Morgan evaluates and } \\
\text { reports to Minisen of Finance. }\end{array}$ & $\begin{array}{l}\text { Bourd of Directors and Ministry } \\
\text { of Finance }\end{array}$ \\
\hline 23 & $\begin{array}{l}\text { Is there a penalty in case } \\
\text { of a lass? }\end{array}$ & & No. & $\begin{array}{l}\text { There is a linit only for foreign } \\
\text { exchange funding }\end{array}$ \\
\hline 3.1 & $\begin{array}{l}\text { Is there a legal limit for } \\
\text { domeaic borrowing? }\end{array}$ & $\begin{array}{l}\text { Yes. the limil is set by the } \\
\text { Financial Lan: }\end{array}$ & No. & $\begin{array}{l}\text { There is a limit only for foreign } \\
\text { exchange funding }\end{array}$ \\
\hline 32 & Who derides for the new limit.s? & The Parliament & & \\
\hline 4.1 & $\begin{array}{l}\text { Who gues the final decision in } \\
\text { an aucrion? }\end{array}$ & AFFA (DMO). & $\begin{array}{l}\text { The officials in cluage of market } \\
\text { operations. }\end{array}$ & $\begin{array}{l}\text { The officer in change of } \\
\text { auctions. }\end{array}$ \\
\hline 5.1 & $\begin{array}{l}\text { Involvement of DMO arith Cash } \\
\text { Management Budget Office. }\end{array}$ & Closely related. & $\begin{array}{l}\text { Closely relatecl. Takes the broad } \\
\text { paramerers }\end{array}$ & Takes for granted. \\
\hline 6.1 & $\begin{array}{l}\text { Dulies other than debt } \\
\text { managemen (in case } \\
\text { of a crisis). }\end{array}$ & $\begin{array}{l}\text { On request of Minisy' of } \\
\text { Finance. gise. opinon } \\
\text { on budget financing. }\end{array}$ & $\begin{array}{l}\text { No special duties other than } \\
\text { taking part in the } \\
\text { advisory committee }\end{array}$ & $\begin{array}{l}\text { Has to ant parallel to the } \\
\text { moretary policy (especially } \\
\text { for foreign exchange cri.sisi. }\end{array}$ \\
\hline
\end{tabular}


7.I Comparative nage of a DMO offucer.

8.1 Fiscal agent.

8.2 Agency services.

9.1 Size of book-ensy form stock

73 percens.

9.2 Vumber of track-keeping staff

10.1 Who handles the staristical follon'-up and projection"'

11.1 Basis of accounting.
Higher than civil servants; comparable to banks.

The Postal Savings Bank. Also for cash managerment, other private banks.

Two officers.

Minissey of Firance.
Higher than ciwil service.

Agency, except for the seulement of G-Bond transactions.

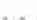

100 percent.

Six officers and 15 cenural bank staff.

Deparment of Finance.

Cash basis for the most par.

Accrual basis for the

adminisuative budget.
Higher than civil servant; lowes than banks (private).

The Swedish Central Securities Depository (VPC)

Redemption of loans: payments of coupons.

100 percent until 1993.

Swedish Central Securities and one person in Debt Office.

The Debi Office.

Cash basis supplemented by cost accounting. 
Table 2.6. Institutional Structure of Debt Offices in OECD Countries: Debt Offices Within the Central Bank

Denmark

1.1 Posiajon of Debt Management Office (DMO) in gorernoment organizavions.

1.2 Chief Executive Officer reports to:

1.3 Boand of Diveczors.

1.4 Degree of independence frem political porier.

2.1 Dues the DMO have a specific performance criteria?

2.2 Who evaluates the perfomance criteria?

2.3 Is thene a penalty in case of a loss?

3.1 Is there a legal limit for domestic borrowing?

3.2 Who decides for the new limins

4.1 Who gis es the final decision in the aucuon?

5.I lmotrement of DHO with Cash Lianagenent Budget Office.

6.1 Duties other than debt management (in case of a crisis).

7.1 Comparative wage of a DMO officer

8.1 Fiscal Agent.

8.2 Agency Services

9.1 Size of book eren form stack.

9.2 Number of Irack-keeping saff.

10.1 Who handles the statisical follon-up and projections?

11 .I Basis of accounting
Denmarks Narionalbank (the cenural bank).

Miristry of Firance.

No.

Borrowing progran is approved by the Ministry" of Finance.

Only' foreign cumency portfolio is subject to evaluation.

Minisin of Finance.

No.

Limit on the level of debt outstanding.

The Parjamert.

Denmarks Nationalbank.

acive involyement.

W'ith the consensus of the Bank and

Minisur of Furance, debr management may become an insmment in handling the crisis. Comprarate to cin'il servant. Coraparable to banks.

Deruriarks Nationalbank Datur

Neastyr INO pezcent.

Danish Securities Cenere (iudependent insinution arith 126 staft).

The bank

Cash basis.
Lnited Kingdom

Treasury and Bank of England.

Treastiry Minister.

Indeperdent aithin the limis set by the

Pefformance against the retrit

Ministers

limit by the funding remit

Bant of England.

Closely related.

Aloney markets and foreign exchange and resen ie managemert.

Comparabse to civil servants. Lower than bank.s (privale).

Bank of England.

Advison Treasur. Discreting, timing of sales, and deciding the acceptable price level of bids for stock

90 percent (optional)

Treasury for propections and Bank's

Financial Statisigial Division and Governments Ceneral Sratistinal Office.

cash and acciual basis for calendar and fiscal year

Source: Organizalion for Economa Cooperatien and Developmens 1OECD)

\section{CInternational Monetary Fund. Not for Redistribution}


Table 2.7. Institutional Structure of Debt Offices in OECD Countries: Debt Offices Within the Ministry of Finance

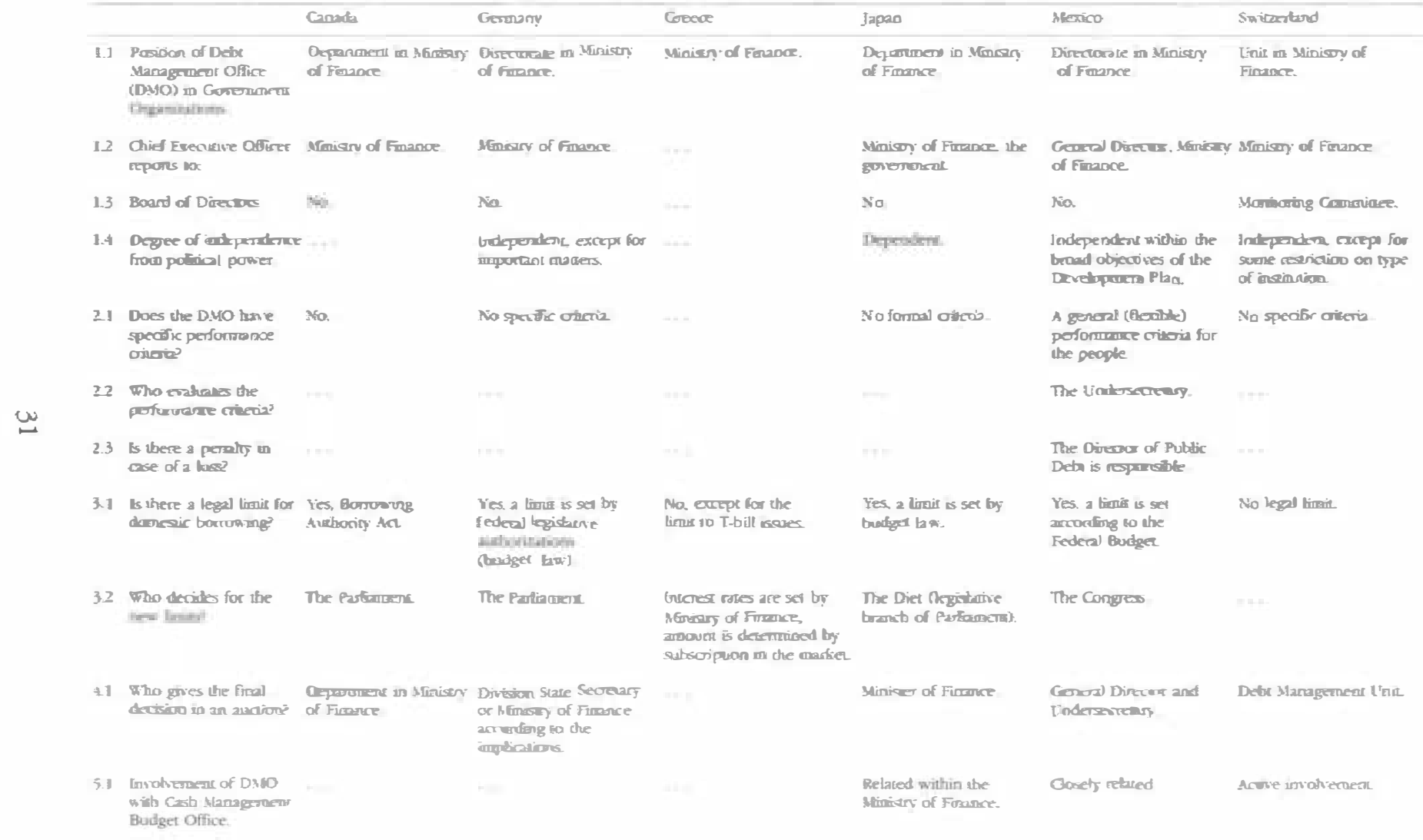


Table 2.7. (concluded)

\begin{tabular}{|c|c|c|c|c|c|c|c|}
\hline & \multirow[b]{2}{*}{ Cinula } & \multirow{2}{*}{ Wemany } & \multirow{2}{*}{ Orever: } & \multirow{2}{*}{ Jajun } & \multirow{2}{*}{ Mesose } & \multirow{2}{*}{ Savideriand } \\
\hline & & & & & & & \\
\hline 6.1 & 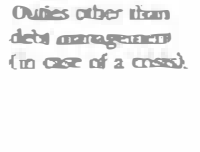 & & 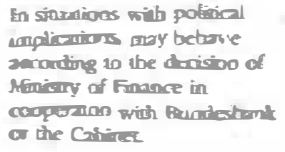 & 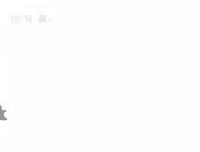 & Nowe & 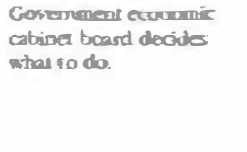 & 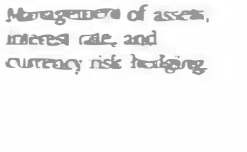 \\
\hline 71 & 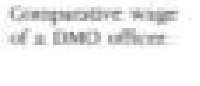 & & 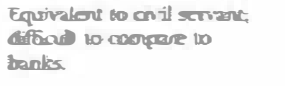 & & 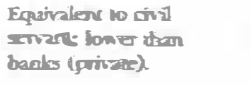 & $\begin{array}{l}\text { Equinalen to civit } \\
\text { servas: lower than } \\
\text { tanks (privat). }\end{array}$ & $\begin{array}{l}\text { Equivalent no civil soran: } \\
\text { lower than tenlss } \\
\text { (gamase) }\end{array}$ \\
\hline 8.1 & Focd गgeषil & The Aurk at Canude. & The Centman Ansbobark. & & 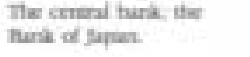 & $\begin{array}{l}\text { Ary privare tank, } \\
\text { cosals Cutant }\end{array}$ & The Solise Nebereal thark. \\
\hline 8.2 & Agency services & 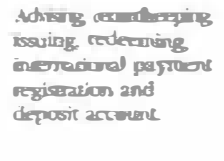 & 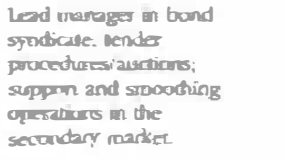 & & 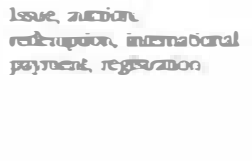 & $\begin{array}{l}\text { tosuing in unerratimal } \\
\text { capital markes }\end{array}$ & 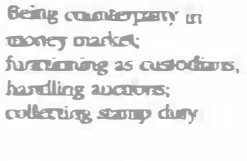 \\
\hline 9.2 & $\begin{array}{l}\text { Number af waxk. } \\
\text { kmpins wat }\end{array}$ & 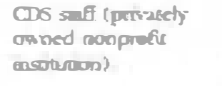 & 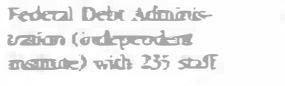 & & 25 ent & 12 staft & 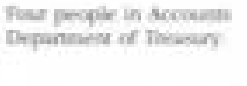 \\
\hline 10.1 & 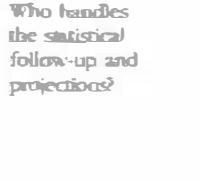 & Rust of Cucent & 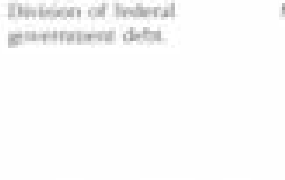 & Merbary of Fhaber. & 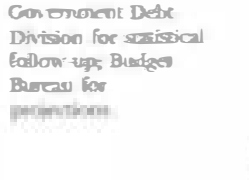 & 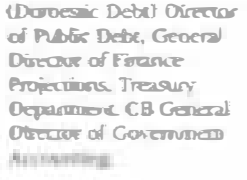 & $\begin{array}{l}\text { Finamial Plan and berfige } \\
\text { Drvision and Treasury } \\
\text { bact offire }\end{array}$ \\
\hline iti & Denie of novolessise & Cabl besis & $\begin{array}{l}\text { Castb or accrial acureting } \\
\text { bo the stacistical purprase }\end{array}$ & & Cosit tenses & 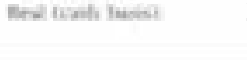 & Cen lases. \\
\hline
\end{tabular}

Source: Orgarization for Economic Cooperation and Developmeni (OEC.D). 
which their performance is evaluated, and remunerate their staff competitively, Denmark, Finland, the Netherlands, and New Zealand also provide their debt offices with a degree of autonomy from the political process; Australia, New Zealand, and, to a limited degree, Denmark impose specific pesformance criteria for their debt agencies. ${ }^{11}$ Selected debt offices that have been reformed recently are surveyed below.

In Ireland, the government delegated in 1990 the borrowing and debt management functions of the Department of Finance and the domestic government bond market operations of the central bank to an autonomous debt agency, the National Treasury Management Agency. The decision to establish the National Treasury Management Agency was justified on the grounds that it would provide clearly defined performance objectives to the agency and a degree of independence from other government objectives, and that the concentration of resources and expertise would result in better risk management and lower debt-servicing costs. The main objective of the National Treasury Management Agency is cast with reference to a low-risk, medium-term benchmark portfolio and aims at funding maturing government debt and annual borrowing requirements at a lower cost than that of the benchmark portfolio, while containing the volatility of annual fiscal debt-service costs.

In New Zealand, the country's debt management strategy is implemented through the New Zealand Debt Management Office, which has been responsible for managing the public debt since debt management policy became disentangled from monetasy policy objectives in 1988. Although the New Zealand Debt Management Office has been placed in a division of the Treasury, it maintains some degree of autonomy from the rest of the government and has its own Advisory Board. The board meets four times a year and comprises, among others, a senior member of the Treasury and experts in risk management theory and practice. The role of the board is to provide advice and oversight across a broad range of strategic and operational risk management issues and to establish greater transparency in the decision-making and supervision process around the debt management office. The Treasurer or head of the New Zealand

"Typically, performance criteria are attached to how etficiently funding transactions are executed, and do not encompass the full debt managenent framework such as funding, liquidity management, and risk management. 
Debt Management Office recommends the strategic benchmark for the sovereign debt, in terms of currency mix and interest rate sensitivity, and the tactical trading limits imposed on the portfolio manager. ${ }^{12}$ Both of these parameters have to be approved by the Minister of Finance.

The objective of the New Zealand Debt Management Office is "to identify a low risk portf olio of net liabilities consistent with the Government aversion to risk, having regard for the expected costs of reducing risk, and to transact in an efficient manner to achieve and maintain that portfolio." To minimize its net risk exposure, the New Zealand Debt Management Office has gradually set the duration and currency profile of its liabilities to match that of its assets. As most of the government assets are denominated in New Zealand dollars, this strategy has entailed a gradual elimination of the net public foreign currency debt - which was achieved in September 1996 - and a lengthening of the duration of the domestic public debt. A significant change introduced by the New Zealand Debt Management Office is the marking to market of all its financial liabilities on a daily basis, and the incorporation of private sector risk management practices in its debt management. The performance of the portfolio managers is measured on a daily basis by comparing the market value of the actual debt portfolio to the strategic benchmark portfolio.

In Sweden, the National Debt Office, which was founded in the eighteenth century, was moved from under the authority of Parliament to that of the Ministry of Finance in 1989 to improve debt management practices. The primary objective of the Swedish National Debt Office is to minimize the costs of borrowing within the limits imposed by monetary policy, and to finance the day-to-day government budget deficit at the minimum possible long-term cost, subject to the government's risk aversion. The board of the Swedish National Debt Office-which is composed, among others, of the Under-Secretary of the Ministry of Finance and members of Parliament--establishes separate benchmark portfolios for the domestic and foreign currency debt, and lays down the permitted deviations from the benchmark portfolios. Within these broad guidelines, the Swedish National Debt Office manages the currency allocation, the

${ }^{12}$ In view of the small amount of risk that the New Zealand Debt Management Office is allowed to take, the position limits around the strategic benchmark portfolio are tightly defined. 
maturity structure, and the market risk of the overall debt portfolio. The performance of the Swedish National Debt Office is evaluated by comparing the cost of the central government debt to that of the benchmark portfolio for the fiscal year.

The performance of the Swedish National Debt Office, which is reviewed by the board on a quarterly basis, has been remarkable in recent years. Between July 1991 and June 1995, the overall savings on both the kronor debt and the foreign currency debt, in relation to the benchmark portfolios, amounted to about 16 billion kronor. During that period, the Swedish National Debt Office also outperformed external managers, who are responsible for managing a small proportion of the foreign currency debt on the same principles as those of the Swedish National Debt Office. Between January 1992 and July 1995, the funding costs of external managers were 1.1 percentage points higher than the corresponding cost for the benchmark portfolio, whereas the Swedish National Debt Office's costs during the same period were 2.5 percentage points below those of the benchmark portfolio (Swedish National Debt Office, 1995).

In the past two years, a small number of emerging market countries have also reformed their debt management practices and introduced benchmarks for their external debt. In Colombia, the Ministry of Finance and Public Credit has implemented a series of measures to strengthen its liability management framework. The measures include increasing the staff in charge of managing and hedging its external debt portfolio, modernizing the data systems supporting the staff, and consolidating the external borrowing strategies of the cential government and the parastatal companies. Particular attention has been paid to attracting staff with the appropriate knowledge and experience in portfolio analysis and to offering competitive remuneration to retain the staff. The main reform introduced by the authorities is to manage the sovereign liability portfolio with respect to a set of low-risk benchmark parameters specifying exchange rate, liquidity, and interest rate risks.

In Hungary, as noted earlier, the debt management office located in the Ministry of Finance has been charged to service the cost of the net sovereign foreign debt. The authorities have decided to align the currency composition of the foreign currency debt through hedging operations with that of the currency basket to which the national currency is pegged. Particular emphasis is being placed on lengthening the maturity of the debt, maintaining more than three- 
fourths of the debt in fixed rate instruments, and evenly spreading debt redemptions to avoid rollover risks.

While some other emerging market countries, including Argentina, Mexico, South Africa, and Turkey, are currently reviewing their debt management practices, in most developing countries, debt offices are nonexistent, debt management objectives are cast in general terms, and there are no formal guidelines on the currency composition and the maturity structure of the public debt.

\section{Institutional Arrangements for Management of Foreign Reserves}

The principles of transparency, accountability, and efficiency apply as well to the reserves management practices of central banks. With the exception of a few central banks (such as in Australia and New Zealand), almost all monetary authorities are reluctant to disclose the composition and maturity structure of their reserves, the instruments in which they are invested, their use of derivative instruments, and the return on their investments. Central banks typically offer several reasons for maintaining such a high level of confidentiality: concerns that market players would view movements in reserves as reflecting central bank expectations of future currency or interest rate movements, which may exacerbate currency fluctuations; concerns that other central banks would object to sharp changes in the level of their exchange rate owing to shifts in reserves; and worries about being criticized for their investment decisions and performance.

Qualms about disclosing reserve management practices, however, apply more to the intervention policies of central banks than to their reserve management policies. The daily intervention policies of the central bank need to remain outside the realm of public knowledge. as there are benefits from surprise intervention in foreign exchange markets. It is unlikely, however, that adjustment in the currency composition of reserves, except if coordinated, would have any effect on the level of exchange rates. As such, the disclosure of the reserves management practices and investment performance of the central bank, on a regular but not frequent basis (such as quarterly or annually), would not constrain monetary or exchange rate policy objectives. 
Although the majority of central banks manage their foreign assets conservatively, several have incurred heavy foreign exchange losses owing to speculative position taking in foreign exchange markets. for instance, the Monetary Authority of Singapore incurred heavy losses in 1981 owing to a currency play on the U.S. dollar/deutsche mark parity. Following these losses, the management of foreign assets was split between the Monetary Authority of Singapore and the Government of Singapore Investment Corporation: the Government of Singapore Investment Corporation manages the bulk of the country's foreign assets, investing in longterm securities, equities, and real estate, while the Monetary Authority of Singapore manages conservatively the foreign reserves needed for intervention purposes..$^{13}$ In the early 1990s, the Mongolian central bank lost almost all its foreign reserves (about $\$ 90$ million), owing to speculation on the foreign exchange markets. More recently. Bank Negara Malaysia reported large foreign exchange losses ( $\$ 3.5$ billion in 1992, and $\$ 2.1$ billion in 1994) owing to speculative position taking against the British pound in 1992. Several other Asian, Latin American, and Middle Eastern central banks take daily positions in foreign exchange markets to increasie the return on their resenes, without disclosure of their gains or losses to the public."1

Even though such speculative hehavior is more the exception than the rile, the management of foreign reserves should receive some public scrutiny, as do other public policy decisions. To achieve this, the institutional framework governing the management of reserves should be broadly similar to that of debt management in its transparent decision-making process and its incentive structure. In particular, the central bank's Board of Directors would define a medium-term strategy for reserves management, based on the central bank's objectives, constraints. and risk preferences. A benchmark portfolio for foreign reserves could then be derived, specilying the currency distribution and maturity structure of foreign reserves, the maximum credit risk exposure of the portfolio, and the

13Such split of foreign assets between the central bankis reserves and the country's foreigı assets is common in several other countries (e.g. China and Kunait).

l'Most of the evidence on central banks' heluavior in foreign exchange markets is gathered from marker sources. 
authorized financial instruments. ${ }^{15}$ The central bank's board would then entrust the day-to-day risk management of the reserves to portfolio managers with strict guidelines on the permissible deviation from the benchmark. The implementation of the board guidelines and the reviewing (on a monthly or bimonthly basis) of the performance of portfolio managers would typically be monitored by the central bank's Investment Committee. To provide the Investment Committee with an external yardstick for evaluating the performance of the internal portfolio managers, a portion of the reserves portfolio could be managed by external managers.

Several central banks have implemented a framework similar to the one just described and have created benchmarks for their foreign reserves, but the majority do not divulge the composition of their benchmarks. We believe that the disclosure of the benchmark and actual reserves portfolios, of the derivatives positions of the central bank (forward and swap contracts), if any, as well as of the performance of internal and external portfolio managers would enhance the accountability of the central bank to the public, without hampering the conduct of monetary policy. ${ }^{16}$ In order not to interfere with the central bank's intervention policies, the frequency of disclosure could be annual or semiannual. The central bank may need to share the currency composition and maturity of the reserves portfolio with the debt management office on a more frequent basis, however, to facilitate the coordination of their management policies.

\section{Strategic Management of Sovereign Assets and Liabilities}

\section{Benchmarks for the Foreign Currency Debt Portfolio}

A key building block in the institutional framework of sovereign risk management is the derivation of a benchmark or target portfo-

\footnotetext{
15The derivation of the reserves benchmark is discussed in more detail in the next section.

${ }^{16}$ As demonstrated during the recent exchange rate crisis in Thailand, a central bank's vilnerability to a currency attack can be assessed accurately only if the net reserves position is disclosed, that is, net of any forward and swap contracts.
} 
lio for the external public debt. ${ }^{17} \mathrm{~A}$ benchmark communicates the medium-term policy objectives of the policymaker to the portfolio manager and the framework within which it has to operate, and provides a measure against which the performance of the manager can be evaluated. Devising a benchmark for its external public debt encourages the policymaker to articulate and quantify its key objectives and cost/risk trade-offs, and to measure the currency, interest rate, liquidity, and credit risks that it is willing to tolerate on its portfolio. In essence, the establishment of a benchmark imposes discipline on the debt management policies of the sovereign.

The selection of a benchmark for the external debt entails specifying the desired currency composition of the debt, and for each of the currencies, specifying the target duration, the maximum maturity, the breakdown between fixed and floating rate instruments, and the financial instruments permitted in the portfolio (such as bank loans, index-linked bonds, and derivatives). Identifying and quantifying these factors is a challenging process, as they depend on the objectives and risk preferences of the policymaker, and the macroeconomic and institutional constraints facing the country. The composition of a benchmark is also strongly influenced by the numéraire in which costs are measured and the horizon over which such costs are estimated.

\section{Objectives}

Debt management objectives vary from one country to another, but in most instances focus solely on lowering annual budget costs rather than on lowering the long-term economic cost of public debt. In recent years, however, a growing number of governments (including Australia, Belgium, and Sweden) have redefined their debt management objectives as minimizing the financial, long-term cost

${ }^{17}$ Benchmarks are mostly useful for the foreign currency debt portfolio. It is difficult to have a benchmark portfolio in the domestic market as the govemment is the largest borrower, and its securities act as benchmarks against which all other instruments are priced and measured. The government may have, however, a target domestic debt portfolio, specified in terms of duration; the target portfolio should serve as a reference point to the portfolio manager rather than as a benchmark to beat. 
of public debt, not just budgetary costs. ${ }^{18}$ In Belgium, the objective of public debt management is "to minimize the financial cost of the public debt, while maintaining market and operating risks at an acceptable level, taking into account the general objectives of budgetary and monetary policies." In Australia, the debt management objective is to minimize the long-term portfolio cost, defined as the time-weighted total debt cost (economic cost), subject to an acceptable level of risk, defined in terms of the annual debt-servicing costs (accounting measure of risk). Similarly, in Sweden, the overriding objective of the debt office is to minimize the long-term cost of the foreign currency debt.

In setting such objectives, governments face a trade-off between minimizing the budget cost of the public debt and lowering the volatility of debt-servicing cost. The extent to which sovereigns place greater emphasis on the first or second part of their objectives would have a significant impact on the target maturity of the benchmark and on the proportion of fixed versus floating rate instruments in the portfolio.

For instance, if the government's main objective is to lower debtservice costs, the target duration of the benchmark portfolio would be short (assuming an upward yield curve), and biased toward issuing short-term or floating rate instiviments. A short duration debt, however, has to be refinanced more frequently, thus exposing the portfolio to greater repricing risk (refinancing at a higher interest rate) or bunching risk (repayment of principal occurring within a short period). As mentioned earlier, the Mexican crisis illustrated the risks of a short duration public debt.

If the government's main objective is to stabilize debt-servicing costs, the target duration of the benchmark would be longer, and biased toward issuing long-term fixed rate debt. In this case, although annual debt-servicing volatility would be lower, the markto-market value of the debt would be more sensitive to interest rate movements. The Irish debt benchmark portfolio, for instance, has a long maturity profile, reflecting the government's bias toward debtservicing stability. However, if the government's main objective is to minimize the volatility of the net present value of the debt on a year-to-year basis (a one-year time horizon), then a debt with a maturity of one year would achieve such an objective.

${ }^{18}$ The optimal level of the debt is a fiscal decision that is taken as a given in the paper. 


\section{Risks}

The key question to address when selecting the composition of the benchmark is the extent of risks (liquidity, market, and credit) or losses that the policymaker is willing to tolerate on its debt portfolio. The risk tolerance of the sovereign may prove tricky to estimate, however, as there is no single measure of sovereign risk. Wheeler (1997) recommends that the government align its risk preferences with those of the average or median citizen, who is typically risk averse. Indeed, as taxpayers cannot fully hedge or avoid the losses that the government incurs on its assets and liabilities portfolios, they would demand from the government to follow a low-risk strategy. The risk preferences of a sovereign entity can also be approximated by taking those of institutions with a similar risk profile, such as pension funds, international financial institutions, life insurance companies, and long-term savings industries. A more systematic estimation of risk tolerance, however, would be to define it in terms of the maximum interest rate costs and excess volatility that can be sustained on the debt portfolio without jeopardizing the budget targets and medium-term objectives of the government. Any risk exceeding this tolerance level should be avoided.

The risk tolerance of a government ultimately depends on the size of the public debt, its currency composition, and its maturity. Any time the debt-service cost is an important element in government expenditures, its variation becomes a key element to watch, and the sovereign is likely to be more concerned with the volatility of its debt. This is particularly the case for governments that have a limited ability to generate foreign currency revenues or to access international markets. When the debt-to-GDP ratio is low, however, the sovereign has greater flexibility in terms of the choice of currencies and duration. In particular, the sovereign may diversify its portfolio to include currencies with lower yield, or shorten the maturity of its portfolio to reduce interest rate costs, knowing that its overall exposure to the higher risks is limited.

\section{Macroeconomic Constraints}

The two key macroeconomic policies that affect the currency composition and maturity profile of the external debt benchmark are the fiscal and monetary policies of the government. Budget targets, for instance, influence the desired duration of the benchmark. Budget targets may include maintaining the level of public debt to 
GDP below a certain percentage (for example, to meet Maastricht criteria); reducing the government debt as a percentage of GDP over a certain horizon; or maintaining the public deficit below a certain percentage of GDP (such as in a stability pact after European Monetary Union). A cap on the debt-to-GDP ratio constrains the extent of volatility tolerated on the debt portfolio and biases the portfolio toward a longer duration. A cap on the budget deficit or on interest payments imposes a minimum average maturity on the portfolio, and constrains the proportion of floating rate debt, thereby limiting the risks of interest rate and exchange rate shocks destabilizing the budget targets.

A monetary policy geared toward pegging the exchange rate to a currency or a basket of currencies biases the choice of currencies in the benchmark portfolio toward the pegged currency (such as in Hungary or Sweden) and limits the proportion of floating rate and short-term domestic debt in the portfolio (as in Belgium), allowing the central bank greater flexibility to influence short-term rates through open market operations. The incompatibility of a pegged exchange rate policy with a short duration domestic debt was demonstrated during the 1992 exchange rate mechanism crisis. Several European central banks were constrained in the defense of their exchange rate during the crisis by the short duration of the public debt: both Italy and Spain had difficulty raising interest rates owing to the short duration of their debt and the rapid impact of the higher rates on public expenditures. In countries where a large portion of the debt is at floating rate, monetary policy would also be constrained by the pass-through of interest rate hikes to domestic borrowers (as was the case in the United Kingdom during the ERMexchange rate mechanism---crisis).

The trade flows of a country may also influence the choice of currencies in the external public debt benchmark, particularly when trade flows dominate capital flows, or when government revenues are directly linked to the export of commodities denominated in foreign currencies (as in Colombia, Mexico, or Saudi Arabia). In economies where the exchange rate is determined by monetary policy and capital flows, rather than by trade flows, the latter need not determine the foreign currency composition of the benchmark. The governments of several industrial countries with debt benchmarks (including Belgium, Denmark, and Ireland) do not take trade flows into account when deciding on the target currency composition of their benchmarks. On the contrary, they expect currency hedging to be undertaken by private entities and corporations. 


\section{Institutional Constraints}

An important institutional constraint that affects the target currency composition and duration of the benchmark is the extent of official borrowing (bilateral or multilateral) in the foreign currency debt portfolio, as the latter is generally denominated in the donors' currencies. Indeed, as more than half of developing countries' long-term debt is from official creditors, a significant part of the debt may be denominated in currencies that are not optimal from a risk management perspective. When developing countries have access to derivative markets or to the World Bank currency conversion scheme discussed earlier, they can hedge their exposure to some of these currencies.

Other institutional constraints that influence the composition benchmark include limiting the currency composition of the foreign debt to that of the foreign reserves portfolio (as in the United Kingdom); maintaining a fixed percentage of foreign borrowing in a specific currency (such as the ECU-European currency unit) to develop the debt market of that currency (as has been done in France and Italy); or partly aligning the currency composition of the external debt with that of national foreign assets (such as the oil stabilization fund in Colombia), to create a natural hedge. National assets are often designated for special purposes, however, and may not necessarily be at the disposal of the sovereign to service its foreign debt.

\section{Numéraire and Horizon}

The choice of a numéraire in which costs are measured is particularly important as it biases the currency composition of the portfolio toward that currency. Considering that the assets and revenues of most governments are denominated in the local currency, it would seem appropriate to measure the liabilities and interest payments of the government in the same currency; the risk-neutral numéraire for a sovereign portfolio is therefore the local currency. ${ }^{19}$ The local currency could be taken as the numéraire even when a country pegs its exchange rate to a currency or to a basket of currencies. Taking the pegged exchange rate as the numéraire would

19Belgium, Denmark, Ireland, and New Zealand, among others, use their local currency as the numeraire for their foreign currency debt. In Colombia, the dollar is used as numéraire, as the closest substitute to the peso, owing to its inportance in trade and capital flows, and exchange rate management.

\section{(C) International Monetary Fund. Not for Redistribution}


only provide the sovereign with a nominal hedge against currency risk, as there is always a risk that the currency is devalued or the peg abandoned.

To avoid frequent changes in its composition, and maintain its neutrality from political considerations (budget cycle), a benchmark would need to be defined over a mediunn-term horizon (for example, over three to five years).

\section{Analytical Framework}

Having identified its objectives, risk preferences, and constraints, the policymaker then has to choose an appropriate analytical framework to model the stochastic properties of the variables involved. and derive the benchmark debt portfolio. There is no unique methodology that can be used to derive a benchmark portfolio. Efficiency frontier models, which estimate the cost/risk characteristics of various currencies and interest rates in a portfolio, have been used by a number of countries (including Belgium, Ireland, and New Zealand) to derive their benchmarks. Drawing the most efficient combination of expected costs, variances, and correlations for the different currencies and interest rates, an efficiency frontierrepresenting a set of portfolios that offer the lowest expected cost for a given level of risk-is obtained. ${ }^{20}$ The most conservative approach would be to choose, among these portfolios, the minimum variance portfolio-the portfolio that yields the lowest costs at the minimum level of risk-as the benchmark portfolio.

The success of a benchmark as a risk management tool is closely linked to its robustness to changes in the underlying assumptions, including various financial market outcomes or interest rate and exchange rate scenarios. Robustness can be assessed by comparing the performance of the benchmark under various price movements (such as lower and higher interest rates. a flattening or a steepening of the yield curve, and an appreciation or depreciation of the domestic currency vis-à-vis the foreign currencies included in the

\footnotetext{
${ }^{20}$ Expected returns are implied from forward exchange rates. swap cunces, and the interest rate term stricture, whereas variances and correlations are derived from historical data. To be risk-neutral, benchmarks should rely on expectations derived from market prices rather than on the government's forecasts of foreign currencies and interest rates.
} 
portfolio). Considering that debt management includes managing the exposure of the sovereign to low-probability high-risk events, the robustness of the benchmark to extreme market conditions (tail events) also has to be tested. This can be done by simulating the effect of market collapses, sharp changes in exchange rates (for example, the ERM crisis, or the Mexico crisis), interest rates, or commodity prices (such as an oil shock) on the benchmark. ${ }^{21}$ The benchmark would be robust, if under all scenarios, its risk-adjusted cost performance is superior to all other portfolios. Depending on the results of the tests, the benchmark may have to be readjusted to reflect the risk tolerance of the sovereign to catastrophic events.

A benchmark is especially effective as a disciplining tool when its composition and the performance of the debt manager relative to the benchmark are made public. Such public disclosure is essential for creating a transparent and accountable debt management policy. Furthermore, in order to be used by policymakers to monitor the performance of their debt managers, a benchmark portfolio needs to be easily replicated in the marketplace as a low-cost passive strategy and structured to track available bond and money market indices (such as J.P. Morgan's or Salomon Rrothers' Money Market and Government Bond Indices). A benchmark that includes complex currency or interest rate hedging strategies may be difficult and costly to replicate by the portfolio manager, either owing to a lack of information on the instruments or to the high transaction costs. Finally, the composition of the benchmark needs to be reviewed regularly to incorporate important changes in the objectives and risk preferences of the government.

\section{Selected Examples of Debt Benchmarks}

A number of countries have developed benchmarks for their public debt. In Ireland, the benchmark is designed to be consistent with the annual debt-service budget within which the National Treasury Management Agency has to operate. As such, the review of the benchmark is annual and matches the budget cycle. The National

\footnotetext{
${ }^{2}$ Stress tests can be simulated by adding standard deviation shifts to the parameters used in estimating the portfolio (e.g., adding one or two deviations to the currency and interest forward or swap rates), or by assigning probabilities to future market scenarios.
} 
Treasury Management Agency attempts to beat the benchmark both by funding at different dates than the benchmark- to take advantage of favorable market opportunities-and by issuing at different maturities than the maturities of the benchmark. The National Treasury Management Agency chooses its maturities subject to a limit on the amount of debt it is permitted to issue, and subject to guidelines on the proportions of foreign currency and floating rate debt. The performance of the debt management office is evaluated by comparing the difference between the actual and benchmark portfolio at the end of the year, both of which are marked to market and net present valued in local currency. Although the currency composition and duration of the Irish benchmark is not made public, the deviations of the actual portfolio from the benchmark tend to be small. As of December 1996, the foreign currency composition of the Irish debt was as follows: 28 percent in deutsche mark, Dutch guilders, and Swiss francs; 42 percent in pounds sterling and French francs; 20 percent in U.S. dollars; 3 percent in ECUs; 5 percent in Japanese yen; and 2 percent in other currencies (National Treasury Management Agency, 1997).

In Sweden, the benchmark serves as the limit within which the foreign currency debt may be exposed to currency and interest rate risks. Within the risk limits laid down by its board, the Swedish National Debt Office takes positions in the foreign exchange and bond markets to bring the long-term cost of the debt below that of the benchmark portfolio. As of December 1996, the currency composition of the Swedish benchmark was 25 percent deutsche mark, 16 percent French francs, 11 percent U.S. dollars, 10 percent pounds sterling, 6 percent Japanese yen, and the rest in ECU and ECUbasket currencies. The currency composition of the benchmark primarily matches the weights of the currencies in the ECU basket ( 82 percent), while the U.S. dollar and the Japanese yen are included in the portfolio for diversification purposes. The duration of the foreign currency debt portfolio is about 2.2 years. The interest rate structure of the benchmark is based on diversified borrowing along the yield curve to reduce shocks to specific parts of the yield curve, and to reduce bunching risk over a certain year.

In Colombia, the recently established external-debt benchmark includes a higher portion of dollar debt ( $80-85$ percent instead of the current 72 percent), in line with the currency exposure of government revenues. The rest of the portfolio is to be divided between deutsche 
mark (about 12 percent) and Japanese yen (about 3 percent). The selection of the benchmark reflects the structure of currency flows into the country and the risk tolerance of the government. The benchmark portfolio has a longer maturity profile than the actual external-debt portfolio, and a smaller share of floating rate debt.

In Hungary, the currency benchmark for the foreign currency debt (foreign and domestic) that is now serviced by the Ministry of Finance matches the composition of the basket to which the national currency is pegged ( 70 percent deutsche mark, 30 percent U.S. dollar). The composition of the remaining foreign currency debt held by the central bank, however, matches that of the foreign exchange reserves. In most developing countries, benchmarks for the external public debt remain nonexistent.

\section{Benchmarks for the Foreign Reserves Portfolio}

The approach discussed in the previous section can be used, to a large extent, for foreign reserves management. The objectives of central banks are more narrowly and tightly defined than those of Ministries of Finance, however, and their risk preferences are generally more conservative. In most industrial countries and emerging markets, foreign reserves are used by central banks primarily for intervention purposes and to meet unexpected liquidity demand. In keeping with this objective, and owing to the limited size of their reserves, central banks typically subordinate investment criteria in the management of their assets to liquidity criteria. Contrary to fund managers, the objective of central banks is to maximize the liquidity of their portfolio subject to an acceptable level of return, rather than to maximize return subject to an acceptable level of liquidity. ${ }^{22}$

Over the past decade, however, central banks' ability to manage either their daily liquidity needs or a speculative attack on their currency has improved significantly. First, the range of instruments

\footnotetext{
${ }^{22}$ Central banks' overriding concem for liquidity is evident in examining the currency composition of their reserves. In 1995, 83 percent of all central banks' international reserves were invested in the three most important and liquid international currencies, the U.S. dollar (62 percent), the deutsche mark (14 percent), and the Japanese yen ( 7 percent). Developing countries invested 61 percent of their foreign reserves in U.S. dollars, 11 percent in deutsche mark, and 7 percent in Japanese yen; the majority of the foreign assets were invested in short-term government securities bill markets.
} 
available for intervention purposes and liquidity funding has expanded: central banks can collateralize their assets or use repurchase agreements to supply liquidity at shost notice, without having to liquidate large amounts of securities; and many central banks can now add currency forwards and options to their armory to defend their exchange rate. Second, a number of bilateral or muitilateral agreements have been established-credit lines or swap lines among central banks and with commercial banks, repurchase agreement facilities among central banks-to buttress foreign reserves. Furthermore, as evident in recent exchange rate crises, foreign reserves no longer constitute the main tool for defending a currency. Only a painful interest rate policy is capable of fending off a speculative attack. In the current environment, therefore, the liquidity constraint has eased, and central banks holding a large stock of reserves need not sacrifice their investment objectives to their liquidity constraints to the same extent. ${ }^{23}$

Indeed, the two objectives-liquidity and return-can be reconciled by splitting the reserves portfolio into a liquidity portfolio and an investment portfolio, and applying different investment criteria for each portfolio. The liquidity portfolio, which would be aimed at meeting regular disbursements and unexpected liquidity demand and for intervention purposes, would be invested largely in the treasury bill markets of the main intervention currencies. The investment portfolio would include a broader set of currencies, maturities, instruments, and markets, and would apply investment principles similar to those of large institutional and pension fiund managers.

The allocation of the assets between the two types of portfolios would differ from one country to another, depending on the exchange rate regime of the country, the size of reserves and their variability, and the structure of the economy. Countries with a fixed or pegged exchange rate regime would evidently allocate a higher proportion of reserves to the liquid portfolio than countries with a

\footnotetext{
${ }^{23}$ This is partly evident by the fact that central banks have increased the portion of long-term securities, especially government securities, in their reserves portfolios since 1990. At the end of 1994, holdings of long-term securities accounted for 44 percent of total reserves. Furthermore, a number of central banks are invesling their reserves in a broader range of instruments and have extended the duration of their portfolio.
} 
floating exchange rate regime. ${ }^{24}$ For developing countries where current account flows dominate capital account flows and where the private sector is small relative to the public sector, foreign reserves are used not solely for intervention purposes, but also to smooth short-term trade flows and finance imports. As such, the level of reserves tends to fluctuate widely and is highly correlated with movements in the trade and current account. In those countries, the portion of reserves allocated to the liquidity portfolio would be high, while the portion allocated to the investment portfolio would be small (about 10 percent to 20 percent). For industrial countries and emerging markets with a diversified economy, however, foreign exchange reserves do not finance imports, which are funded by the private sector, and hence, there is no significant correlation between foreign reserves and current account flows. Furthermore, with the increased financial integration of the past decade, the volume of financial assets held by private investors has increased significantly in most emerging and developing countries, thereby increasing the importance of the capital account relative to the current account as a determinant of the optimal level of reserves. Indeed, in most emerging markets, the size of forcign reserves should be determined by the size of capital flows and the exchange rate regime and not by the size of imports. In those countries, the portion of reserves allocated to the investment portfolio can be larger.

In a similar vein to debt management, sophisticated management of foreign reserves entails deriving benchmarks for both the liquidity and investment portfolios. The optimization approach discussed earlier also may be used to derive the currency distribution and duration of the benchmark that would minimize exposure to currency and interest rate risks. ${ }^{25}$ The currency composition and duration of the benchmark portfolios would be influenced by the objectives of the central bank; the macroeconomic environment of the country (exchange rate arrangements, monetary policy, trade and current account flows, and currency denomination of debt-service pay-

${ }^{24}$ In this paper, we do not estimate quantitatively the optimal split between the two portfolios. In a broad sense, the portion of reserves allocated to the liquidity portfolio would be based on past intervention and withdrawal pattems, the variability of liquidity needs, and the estimation of future liquidity needs under various scenarios of currency attacks.

${ }^{25}$ Several countries, including Australia, Denmark, Finland, New Zealand, and Norway use portfolio optimization to derive their reserves benchmarks. 
ments); institutional constraints (agreements among central banks of concerted or coordinated intervention, restrictions on the maximum exposure to certain markets and currencies); and risk preferences.

Typically, the currency composition of the liquidity portfolio would be limited to the three main intervention currencies--the U.S. dollar, the Japanese yen, and the deutsche mark - and the duration would be short (zero to three months), with most of the assets invested in highly liquid short-term government debt. The currency composition of the investment-portfolio benchmark would include a broader array of currencies than the liquidity portfolio, although it should be invested predominantly in the major currencies (G-10 currencies). Indeed, the currencies included in the investment portfolio should be selected according to their stability and diversification benefits, with the overriding goal of preserving the real value of reserves, rather than the nominal value.

The target duration of the investment-portfolio benchmark would be longer than that of the liquidity portfolio (ranging from one year to three years), and closer to that of the external-liability portfolio. Matching as closely as possible the currency composition and duration of the investment portfolio with those of the external public debt would reduce the net exposure of the public sector to currency and interest rate risks. As the investment portfolio would be less constrained by liquidity risk than the liquidity benchmark, the foreign reserves can be invested in a broader spectrum of maturities (up to 10 years) and securities, provided the investments fulfill the credit risk criteria of the central bank. In particular, foreign reserves may be invested in securities issued by government agencies, local governments, regional and international organizations, and highly rated commercial banks

The target duration would vary across the currencies of the benchmark, however, owing to differences in liquidity and yield curves in the various bond markets. Most short-term government securities markets, with the exception of the U.S. market, lack liquidity and depth. The duration of the U.S. dollar reserves portfolio may therefore have to be short to compensate for the longer duration of the nondollar portfolio. ${ }^{26}$ Similarly, although the investment bench-

${ }^{26}$ According to the Bank for International Settlements (BIS) estimates, the duration for the deutsche mark and Japanese yen reserves portfolios is longer than the U.S. dollar portfolio, owing to their less liquid short-term securities markets. 
mark specifies the maximum tolerable credit risk for the portfolio, the credit risk may differ among markets. For instance, the central bank may have to reduce or avoid taking a bank credit risk in countries that have liquid short-term govemment securities markets to offset its greater exposure to bank risk in countries with underdeveloped short-term government securities markets.

As in the case of debt management, the central bank's board would define the permissible financial instruments in which reserves can be invested, the maximum credit risk tolerated on the portfolio, the market indices that would be used to track the performance of portfolio managers, and the discretionary guidelines imposed on managers. Both the investment-portfolio benchmark and the performance of the managers should be made public. The liquidity benchmark may not be made public, as it is primarily used for intervention purposes.

\section{Selected Examples of Foreign Reserves Benchmarks}

Although a number of central banks have developed benchmarks for their reserves, we are only aware of relatively few that officially reveal the currency composition and asset breakdown of their actual and benchmark reserves portfolio.

In Australia, the Investment Committee of the Reserve Bank of Australia has defined a benchmark for foreign currency assets composed of 40 percent U.S. dollars, 30 percent yen, and 30 percent deutsche mark (Table 2.8). One of the reasons for limiting holdings to these three currencies is their large and liquid government securities markets. The Reserve Bank of Australia did not include other

Table 2.8. Benchmarks for Foreign Currency Ạssets of Australia

\begin{tabular}{|c|c|c|c|}
\hline & $\begin{array}{c}\text { U.S. } \\
\text { Dollars }\end{array}$ & Yen & $\begin{array}{l}\text { European } \\
\text { Currencies }\end{array}$ \\
\hline \multicolumn{4}{|c|}{$\begin{array}{l}\text { Currency and asset composition } \\
\text { (percent of total assets) }\end{array}$} \\
\hline Benchmark & 40 & 30 & 30 \\
\hline Discretionaty range & $20-60$ & $10-50$ & $10-50$ \\
\hline \multicolumn{4}{|l|}{ Duration (months) } \\
\hline Benchmark & 12 & 30 & 30 \\
\hline Discretionaiy range & $0-18$ & $0-36$ & $0-36$ \\
\hline
\end{tabular}

Source: Reserve Bank of Australia, 1996. 
major currencies in its portfolio either because of a lack of diversification benefits from adding more currencies or because of the lack of resources for monitoring a large number of financial markets. The target duration for the U.S. dollar assets is 12 months; 30 months for yen assets; and 30 months for deutsche mark assets. The weighted average of the maturity of investments cannot exceed three years, although the maximum maturity can extend to 10 years. Resesves are primarily invested in government securities and to a lesser extent in bank deposits. The Reserve Bank of Australia prefers repurchase agreements secured with government bonds as collateral to bank deposits, as the return is higher than in the interbank market. Resesves are managed primarily by internal portfolio managers, but external portfolio managers are used for occasional reviews of benchmarks.

In New Zealand, the foreign reserves benchmark is composed of U.S. dollars (about 55 percent), Japanese yen (about 20 percent), deutsche mark (about 20 percent), and pounds sterling and French francs (about 5 percent). ${ }^{27}$ The central bank has separate investment benchmarks for each of the five currencies. For instance, the U.S. dollar portfolio has several components: a money market portfolio that tracks a money market index derived within the central bank; and a medium- to long-term bond portfolio that tracks the returns on the J.P. Morgan 1-10 years and 1-30 years U.S. government bond indices. The benchmark specifies that the minimum acceptable credit rating (Moody's) for investments for foreign reserves is Aa3. As of March 31, 1995, the breakdown of the reserves benchmark portfolio by instruments was 67 percent in bonds, 16 percent in commercial bank deposits, 22 percent in other central bank deposits (including the BIS), and 6 percent in treasury bills.

Some central banks, such as the Hong Kong Monetary Authority, do not reveal the actual composition of their resesves, but acknowledge that they split their reserves into a liquidity portf $\bullet$ lio, an investment portfolio, and a hedging pontolio, and that they use benchmarks. The liquidity portfolio of the Hong Kong Monetary Authority is invested in treasury bills of less than one year and, to a limited extent, in bank deposits of the G-7 currencies. The investment portfolio is also invested in liquid assets but with longer maturities (up to 10 years) bonds and in equity indices (S\&P 500).

${ }^{27}$ See Resenve Bank Bulletin, 1995. 


\section{Tactical Management of Sovereign Assets and Liabilities}

Sound risk management would necessarily require that, at times, the portfolio manager moves the actual debt or reserves portfolio away from the benchmark portfolio to adjust to changes in market conditions or to incorporate new expectations about market developments. As any divergence from the strategic benchmark postfolio introduces currency and interest rate risks, however, the Ministry of Finance or central bank would need to cap those risks by imposing strict guidelines on the maximum permissible deviation from the benchmark and the extent to which the sovereign portfolio may be exposed to market risks.

\section{Discretionary Margins}

The discretion of porffolio managers over the management of sovereign debt and foreign reserves varies from one country to another, depending on the risk preferences of the sovereign, the size of the public debt and foreign reserves, and the expertise of portfolio managers. A government burdened with a large debt-service cost relative to its budgetary expenditure would necessarily limit the extent to which debt managers can deviate from the benchmark portfolio, owing to the large fiscal consequences of a risky strategy. In such instances, the debt manager would follow a passive investment strategy, solely ensuring that the actual debt portfolio follows the benchmark portfolio closely. Governments with a small debt burden and the means to acquire sophisticated risk management systems and experienced portfolio managers have greater flexibility in allowing their debt managers to pursue an active debt management strategy. For instance, debt managers may be encouraged to outperform the benchmark by deviating from the benchmark's currency weights and duration by a certain percentage, according to their expectations of future market movements. Active debt management may also involve taking advantage of arbitrage opportunities and irregularities in the market, through liquidity or credit transformation transactions.

In a similar vein, the central bank of a country Delonging to a currency block has less freedom to change the currency composition 
of its reserves than a country with a floating exchange rate. Similarly, the central bank of a large country is more constrained in varying the currency allocation of its reserves than the central bank of a small country, owing to its potential impact on foreign exchange markets.

In Sweden, the Swedish Debt Management Office may deviate from the currency composition of the debt benchmark portfolio by 3 percentage points, and by 0.5 percentage point from the duration of the benchmark. Ireland does not reveal the extent of deviation tolerated on its debt portfolio, but acknowledges that it is small. In Denmark and Hungary, the maximum level of deviation from the benchmark has been set at 5 percent. In Belgium, the government has opted to pursue a passive debt management strategy owing to the high operational costs of active management. Canada has also renounced an active debt management policy and only focuses on minimizing refunding risks.

The majority of central banks do not reveal the margin of discretion granted to their portfolio managers. Australia and New Zealand are the two notable exceptions. In Australia, the Reserve Bank provides ample discretion to its portfolio managers in managing the reserves portfolio, partly on account of their limited impact on international financial markets (Tables 2.8 and 2.9). In New Zealand, the extent to which the portfolio manager can deviate from the reserves benchmark portfolio is based on a "funds-at-risk" approach: the manager has to ensure (with 95 percent confidence) that the value

Table 2.9. Comparison of Actual and Benchmark Returns for Australia's Reserves Portfolio

\begin{tabular}{lccc}
\hline & $\begin{array}{c}\text { Rates of Return (in SDRs) } \\
\text { (Percent) } \\
\text { Bctual }\end{array}$ & $\begin{array}{c}\text { Value of Difference Between } \\
\text { Actual and Benchmark Returns }\end{array}$ \\
\cline { 3 - 4 } $1991-92$ & 9.8 & 8.9 & 165 \\
$1992-93$ & 16.3 & 11.6 & 420 \\
$1993-94$ & 4.0 & 3.8 & 31 \\
$1994-95$ & 5.2 & 7.4 & -331 \\
$1995-96$ & 4.0 & 3.7 & 40 \\
\hline
\end{tabular}

Source: Reserve Bark of Australia, 1996. 
of the portfolio does not fall by more than three-hundredths of a percent, on any one day.

Most of the discretionary margins imposed on portfolio managers, with the exception of New Zealand, are based on arbitrary rules and are not risk-adjusted. A more sophisticated approach to estimate the extent of market risk that a sovereign is willing to tolerate on its portfolio is the value-at-risk (VAR) approach. ${ }^{28}$ The VAR approach can be used to measure within a certain degree of confidence $(95$ percent and 99 percent) the potential loss of the actual portfolio against the benchmark over a specific period (such as the next 30 days or 100 days). The portfolio's VAR is obtained by estimating the relationships between risk variables (exchange rates, interest rates, and shifts in yield curves or swap curves) across the portfolio, and the effect of changes in these variables on the mark-to-market value of the portfolio. The expected change in the level and volatility of exchange rates and interest rates is extrapolated from historical prices and implied volatilities. The sovereign can then determine the maximum loss that it is willing to accept on its portfolio, and translate it into maximum deviation targets from the benchmark, or maximum daily shortfall on the portfolio. These VAR limits should be imposed on each currency of the portfolio rather than on the whole portfolio. The VAR approach is useful for a sovereign portfolio, as the latter generally does not contain options, which are more difficult to estimate, and is invested in the government securities of the main currencies, where historical volatilities and correlations are readily available. The VAR approach is particularly helpful to central banks, because of the shorter horizon of their portfolio.

\section{Management of Currency and Interest Rate Risks}

The most flexible financial tools for aligning the actual sovereign portfolio with the benchmark, and for hedging the portfolio from currency and interest rate risks, are derivative instruments (such as currency and interest rate swaps, forward contracts, futures, and options). ${ }^{29}$ Derivatives enable the portfolio manager to move the ac-

${ }^{28}$ Sweden is also considering moving to a VAR approach.

${ }^{29} \mathrm{~A}$ number of sovereigns, however, are not allowed to use derivatives by their constitution, or do not have the legal framework or technical capacity to manage the cash flows created by derivatives. 
tual sovereign portfolio to the benchmark portfolio without selling large amounts of securities, which could disrupt financial markets, and to unbundle the various risks inherent to an underlying security and manage them separately. All the derivative positions of the portfolio manager need to be carried within the guidelines of the policymaker and should only be taken on the underlying debt or reserves portfolio, without any net or leveraged position.

A number of debt managers use derivatives to borrow in a wide range of markets, currencies, and maturities, while maintaining both the currency composition and duration of the actual portfolio in line with those of the benchmark. In Sweden, for instance, about twothirds of the government's external borrowing is raised in U.S. dollars and Japanese yen, although the benchmark's allocation for these two currencies is 18 percent. Similarly, the maturities of the debt instruments are spread along the yield cuive, although the modified duration of the benchmark portfolio is equal to two years (equivalent to 2.2 year duration). In both instances, swaps, forwards, and futures are used by the Swedish Debt Management Office to bring the actual portfolio in line with the benchmark's weights. ${ }^{30}$ In Ireland, in addition to interest rate swaps, portfolio managers use bond futures to transform the interest rate profile of the foreign currency debt to the benchmark portfolio. In New Zealand, interest rate futures are used to manage the interest rate risk between the foreign reserves poition that acts as a liquidity buffer for debt repayments and the short-term foreign currency debt. In Australia, although foreign currency debt has not been issued since 1987, a foreign currency exposure has been maintained through domestic swap transactions; swaps have been used instead of direct offshore issuance because of the lower cost. In Denmark, derivatives are used to manage the net exposure of the sovereign portfolio, by matching the daily currency and interest rate exposure of the foreign currency debt with that of its foreign assets. Central banks' portfolio managers increasingly use derivative instruments to manage their currency and interest rate exposures, and to diversify their risk across several bond markets without incurring currency

30The size of the swap portfolio (kronor 440 billion) is equal to the foreign currency debt portfolio (kronor $\$ 20$ billion). 
risk. The most common derivatives used are forward and swap agreements, futures, and, to a lesser extent. options. ${ }^{3.1}$

The use of derivatives, however, introduces credit risk or counterparty risk to the exposure of the portfolio. In the case of a forward or swap transaction, counterparty risk arises because the counterparty to the transaction may not fuifill its obligation and default on the contract; in the case of a futures contract, counterparty risk arises if the exchange defaults on its obligation. The counterparty risk for exchange-traded derivatives is lower than for OTC derivatives, however, as exchanges have clearinghouses that have a supervisory and insurance role, do not keep open positions on contracts, and require call margins from investors. ${ }^{32}$ To reduce its exposure to credit risk, the sovereign should impose strict guidelines on portfolio managers, either by limiting their transactions to derivatives traded on reputable exchanges or to trading OTC derivatives only with highly rated financial institutions (such as those with at least an AA/Aa2 credit rating from Moody's and Standard \& Poor's). Managing counterparty risk is especially important when the sovereign has a large swap portfolio. In Sweden, the Swedish Natirnal Debt Office's swap transactions are only conducted with institutions rated AA or higher, whereas in Australia, swaps are arranged aith financial intermediaries rated AA- or higher. In Ireland, credit risk exposure is restricted to institutions with at least an AA rating.

Until recently, most developing countries have been unable to access international derivative markets owing to their high credit risk, or have had to pay prohibitively high premiums or exhaust their bank credit lines to acquire derivative securities with long maturi-

${ }^{3}$ Both futures and forwards allow the manager to lock in the refinancing of the debt at the current exchange rate and remove the exchange rate risk during that period. The main difference between the two instruments is that the former are standardized contracts traded on exchanges and limited to a small nunulser of currencies, whereas the latter are over-the-counter (OTC) transatctions that are customized to the client and cover a larger number of currencies.

${ }^{32}$ Any time a borrower buys or sells a futures contract. it has to maintiun margin requirements at the exchange that fluctuates daily and that has to remain above a certain minimum balance, called the maintenance balance. The position is constantly marked to market. Thus, when the price rises above the inıtial price, the seller pays the price differential to the exchange from the margin account, and the buyer's account is in turn credited by the same amount When the maintenance balance falls below a certain minimum. it has to be supplemented with outside funds, or is closed.

\section{(C)International Monetary Fund. Not for Redistribution}


ties, thereby limiting their usefulness. Furthermore, in a large number of developing countries, derivative instruments in the local currency are either nonexistent or available only for short-term maturities. Several developing countries have since improved their international credit standing, through macroeconomic adjustment and microeconomic reform, thereby gaining greater access to international capital and derivative markets. This is demonstrated by the large number of Asian and Latin American countries that have investment grade status and are accessing international capital markets. A large number of emerging markets have also developed forward and futures contracts on the domestic currency and interest rates. 33

\section{Management of Currency Risk}

There are a number of derivative instruments and strategies that can be used by porffolio managers to reduce the currency risk exposure of the sovereign portfolio. A short-term foreign currency exposure can be hedged with currency futures and forward contracts, while the most convenient instruments for hedging a long-term foreign currency exposure are foreign currency swaps. The main advantage of currency derivatives is that they allow an investor to invest in the asset markets of a currency without taking on currency risk, or to invest in the currency markets without investing in the asset markets of that currency. This separation between asset and currency markets allows managers to decouple currency risk from interest rate and liquidity risk and to achieve interest rate diversification, while maintaining a targeted currency mix. For instance, a central bank may want to increase its investments in Japanese government securities without increasing its exposure to the Japanese yen. This would be achieved by buying a government bond and simultaneously entering into a forward or swap transaction to convert the yen into U.S. dollars. A central bank could also create synthetic money market instruments in markets lacking liquid short-term gov-

33Futures markets exist in several emerging markets, including Brazil, Malaysia. and Chile. Forward markets, especially for short-term maturity contracts (up to six months), exist in several Asian and Latin American countries. Swap markets, although still rare, exist in some emerging countries, including Brazil, Chile, and India. 
ernment securities by buying treasury bills in those markets and covering their exchange rate exposure with a currency swap.

In addition to futures and swaps, options are convenient instruments to manage risks. Options perform similar hedging functions as swaps and futures, but give the holder of the contract the right, but not the obligation, to buy or sell a financial asset at a specified price at or until a specified date. To obtain this right, the investor has to pay an up-front premium. The premium, unlike forward or futures contracts, is the maximum loss that an options buyer would incur on the contract. The advantage of options is that they allow the investor to hedge against the downside risk of exchange rates movements without forgoing the benefits of the upside. The use of options is particularly attractive to developing countries because they do not require the latter to block credit lines to guarantee their commitment on futures and forwards contracts. Options also enable developing countries to hedge a long-term exposure without being handicapped by their credit risk.

Although options are useful tools for managing financial risks, the size of the up-front cost may prevent cash-constrained countries from using them. There are, however, several ways to reduce the premium on options. For instance, a central bank that holds a currency for monetary policy purposes but is worried about the downside risk could hedge part of its exposure by purchasing a put option on that currency and partially offset the premium on the put option by selling a call option, thereby limiting both upper and lower movements on the currency's value. The central bank could also lower the option premium either by hedging against only a large depreciation of the currency (at a strike price out-of-themoney) or by hedging a currency range rather than a single currency rate. For example, suppose Indonesia, which has a large yendenominated debt but has most of its revenues in U.S. dollars, desires to hedge its foreign currency debt against an appreciation of the Japanese yen. Rather than hedging its currency exposure through a currency swap, thereby forgoing the benefits of a depreciation of the yen, the manager could hedge the portfolio against volatilities exceeding a 10 percent range. ${ }^{34}$ To illustrate this example, taking a spot rate of $¥ 100$ to the dollar, the goal of the manager

${ }^{3}$ This is based on the assumption that such a range is an acceptable currency risk exposure by the Ministry of Finance. 
would be to hedge the portfolio from fluctuations beyond the $¥ 9$ - $¥ 110$ range. The hedge, referred to as an exchange rate collar or range forward collar, would be constructed by (1) writing an outof-the-money put option on the yen against the dollar, struck at one end of the desired fluctuation range, $¥ 110$ and (2) buying an out-ofthe-money call option on the yen against the dollar, struck at the other end of the range, $¥ 90$. The premium payment on the call option would be offset by the premium received on the put option.

The option premium can also be reduced by using average rate currency options, which are options that hedge against the average rate of the spot rate during the lifetime of the option, as opposed to the spot rate at the expiration of the option. These options cost less (up to 20 percent) than straight call options because of the dampened volatility effect of the average rate as time passes. Countries that peg their currencies to a basket of currencies can hedge their exposure by buying average rate call options on the basket of currencies. The premium on such options is low because the counterparty can cover its currency risk by crossing the currencies.

Basket currency options can also be used to hedge a multicurrency portfolio. A basket option creates an index that represents the value of the portfolio of foreign exchange positions against the base currency. There are several advantages to these options. First, depending on the extent of cross-currency correlations in the basket, the premium on basket options can be up to 20 percent lower than that on standard options. Second, basket options allow the manager to ensure that the value of its portfolio does not fall below a certain level--cletermined by the strike price of the option-while benefiting from the upside gains.

Options are not only useful for risk management purposes but also for credit enhancement. Sovereigns can enhance the attractiveness of their bonds, for instance, by including a put option on their bonds-the option to call the bonds before maturity-thereby reducing the risk exposure of the lender to a default risk. Sovereigns can also improve the terms of borrowing by offering the lender the choice to convert the principal of the loan at maturity to another currency. In this case, only interest rate payments will be subject to currency risk. In both instances, the borrower would benefit from a lower interest rate on the borrowing, albeit at the expense of a higher risk exposure. Attaching strings to the issuance of bonds is especially beneficial for developing countries accessing international capital markets 
for the first time, as it reduces their borrowing cost and provides them with a wider spectrum of lenders. A number of countries (including Argentina, Brazil, and Mexico) that reentered international capital markets in the early 1990s attached put options, ranging from one to three years, on their bonds (World Bank, 1996b). In fact, almost 20 percent of the total bonds issued by developing countries in the early 1990s had put options attached to them.

\section{Management of Interest Rate Risk}

Domestic debt is for a large number of countries the main component of their total debt, and, hence, interest rate risk is the key risk to manage. Indeed, an important task of the portfolio manager is to constantly adjust the sovereign portfolio to changes in interest rates, to prevent significant deviations from the benchmark portfolio. For instance, when interest rates increase, the duration of the actual portfolio shortens, thereby inducing the manager to lengthen it to bring it back in line with the benchmark duration. The most efficient and cost-effective method for altering the duration of the portfolio is to take positions on the yield curve through interest rate swaps, futures, and options rather than to trade the underlying securities. The manager could instantly reduce the duration of its portfolio while maintaining the asset allocation unchanged, for example, by selling a seven-year treasury futures contract and buying a five-year contract.

The day-to-day responsibilities of the portfolio manager also entaif hedging the short-term and floating rate debt components of the sovereign portfolio, as the latter are the most vulnerable to interest rate risk. About one-half of developing countries' foreign currency debt is exposed to interest rate risk. In 1995, almost 40 percent of developing countries' long-term debt was at variable rates, and almost 20 percent of their total external debt was short term. As most of developing countries' U.S. dollar-denominated short-term and variable debt is indexed to LIBOR (the London Interbank Offered Rate), it is relatively easy to hedge against variations in LIBOR by selling Eurodollar futures contracts. ${ }^{35}$ By selling a Eurodollar futures contract, the manager

${ }^{35} \mathrm{~A}$ Eurodollar futures conract is an obligation to buy or sell at a predetermined price on a specified date a Eurodollar time deposit that is indexed to the LIBOR. Eurodollar futures have maturities ranging from three months to three years, although maturities above two years tend to be less liquid. 
locks the debt at a fixed rate for the duration of the contract: any increase in LIBOR that results in higher interest payments is covered by profits on the futures position. In order to hedge interest rate risk for more than one payment period, Eurodollar futures can be combined in a sequence of contracts, referred to as a "strip" hedge. Strip hedges that involve a long sequence of contracts tend to be illiquid, however, and demand a high premium.

In addition to futures, interest rate swaps (IRS) and swap options (or swaptions)--options to enter into a swap agreement---can be used to hedge against LIBOR movements and to convert the variable rate debt into fixed rate debt. In a typical IRS transaction, the portfolio manager agrees with a commercial bank to exchange a stream of fixed interest payments for a stream of floating interest payments for the duration of the bond. The commercial bank assumes the risk of this conversion by taking a premium over the expected floating rate during that period. IRS contracts are popular instruments because no premium is paid at the beginning of the transaction, the risk premiums are low, and their maturities extend up to ten years. In IRS transactions involving long maturities, however, countries with a poor debt-servicing history or high foreign currency debt may have difficulty finding institutions that are willing to take their counterparty risk.

The exposure of the debt portfolio to interest rate fluctuations can also be hedged through the use of interest rate caps or floors. ${ }^{36}$ Interest rate caps, which are equivalent to put options, ensure the borrower that interest payments will not exceed a certain level-the cap--during the duration of the loan. In the event that interest rates rise above that level, the seller of the cap would reimburse the cap holder for all interest payments above the cap. Interest rate floors, which are equivalent to call options, ensure the borrower that if the interest rate falls below a certain level-the floor-the borrower agrees to sell the asset at the strike price. ${ }^{37}$ Interest rate caps on floating rate debt, or interest rate floors on fixed rate debt, are especially useful for ensuring that the sovereign's annual interest payments do not exceed budget targets. Although caps and floors can

${ }^{36}$ Caps or floors are typically contingent on the LIBOR rate or the price of oil.

37The premium of caps and floors is based on the length of the contract, the expected volatility of the interest rate, and the level of the cap or the floor. 
cover long maturities (up to ten years), their premiums tend to be high. By combining interest caps and floors to create collars or cylinders, which define lower and upper bounds to the borrower's interest payments, the premium can be reduced or eliminated: the up-front payment for buying the cap is partly offset or tinanced by the premium received by selling the floor. This hedging strategy can be maintained on a rolling basis with a new position taken every time the collar matures.

Finally, other interest rate risks that the portfolio manager may have to hedge against include nonparallel yield curve shifts, which occur when the level of interest rates does not change uniformly across all maturities; changes in the slope of the yield curve, which occur when yields for shorter maturities change at a different rate than yields for longer maturities; changes in the shape of the yield cuive, which occur when changes in the yields for the middle maturities are different from yield changes at the extremes of the yield curve; and yield spread risk, which is the risk of a widening of yield spreads between different markets of the same currency (such as between treasury bills and Eurodollar deposits).

\section{Conclusions}

In a world of mobile capital tlows and integrated capital markets. governments holding large and unhedged foreign currency lialsilities are exposed to risks that they may not always be able to manage adequately. An important step toward reducing the vulnerability of emerging market economies to volatility from international capital markets is to improve the institutional arrangement governing debt policy, so that it promotes a professional, transparent, and publicly accountable incentive structure. The experience of the governments that have already reformed their debt management practices suggests that such objectives are best achieved if debt management is assigned to a separate debt agency with a degree of autonomy from political intluence. Under such an ariangement, the Ministry of Finance formulates and publicly announces its debt strategy, while the debt agency implements that strategy and manages the clay-to-day exposure of the debt portfolio according to the investment guidelines of the Ministry of Finance. 
Regrouping liabilities management under a separate and autonomous agency can improve the assessment and management of the risk exposure of the country to risks and can shield the debt agency from political pressures. It also enables the authorities to endow the agency with a clearly defined objective and organize it to achieve such an objective, without being hampered by either the management structure or pay scale of the public sector. Furthermore, assigning debt management to an autonomous debt agency enables a clear separation of responsibilities between debt management and monetary policy, thereby avoiding the conflicts of interest that arise when a central bank is in charge of both functions.

An appropriate and transparent vehicle for communicating the objectives and preferences of the Ministry of Finance to the debt office is the establishment of benchmarks for the foreign currency debt portfolio. The benchmark portfolios, which can be derived from portfolio optimization, would specify the currency composition, the maturity structure, and the permissible instruments of the sovereign debt portfolio. A key element of this framework is to disclose to the public on a regular basis both the benchmark portfolio and the performance of the debt manager relative to the benchmark. Such public disclosure is essential for creating a transparent and accountable debt management policy.

Active management of the sovereign debt portfolio should only be undertaken when the resources to acquire reliable risk management systems and hire experienced portfolio managers are available. Otherwise, debt management should be limited to a low-cost strategy of replicating the benchmark passively. When portfolio managers are engaged in active management, the sovereign should cap the exposure of the debt portfolio to market and credit risks, by imposing strict limits on the margin of deviation of the portfolio manager from the benchmark.

Finally, contrary to current practices, reserves management would also benefit from public scrutiny that holds the central bank accountable for its investment decisions and performance. To reconcile its investment objectives with its liquidity constraints, the central bank can split its reserves portfolio into a liquidity portfolio--aimed at meeting regular liquidity demand and for intervention purposes - and an investment portfolio, managed according to investment principles similar to those of large institutional and pension fund managers. As in debt management, public disclosure 
of the benchniark and actual reserves portfolios, as well as the performance of portfolio managers, would encourage the adoption of sound reserves management practices.

\section{References}

Barro, Robett J., 1989, "Optimal Debt Management." NBER Working Paper 5327 (Cambridge, Mass.: National Bureau of Economic Research).

Battelino, R., 1994. "Should Central Bank Assets Be Managed Againnst a Multicurrency Benchmark?" 1994 Central Bank Seminar: Salomon Brothers,

Calvo, Guillermo, and Morris Goldstein, 1995, "Crisis Prevention and Crisis Management after Mexico: What Role for the Official Sector" (Washington: Institute for International Economics).

Carracedo, Montserrat Ferre, 1995. "Survey of Public Debt Management Framework in Selected Countries."

Claessens, Stijn. 1988. "The Optimal Currency Composition of External Debt," World Bank Working Paper No. 14 (Washington: World Bank).

_. 1992, "Optimal Currency Composition of kxternal Debt: Theory and Applications to Mexico and Brazil," World Bank Econemic Reviewe. Vol. 6. No. 3. pp. $503-28$.

Cline, William R., 1995, International Debt Reexamined (Washington: Institute for International Economics).

de Fontenay, Patrick, Gian Maria Milesi-Ferretti, and Huw Pill, 1995. "The Role of Foreign Currency Debt in Public Debt Management," Working Paper 95/21 (Washington: International Monetary Fund).

Dooley, Michael P.. 1997, "Governments` Debt and Asset Management and Financial Crises: Sellers Beware," Risk Management for Sotereign Countries (Waslington: lnternational Monetary Fund).

Eaker, Mark R., Dwight M. Grant, and Nelson Woodard, 1993, "A Multinatıonal Examination of International Equity and Bond Investment with Currency Hedging," Journal of Futures Markets, Vol. 13, No. 3. pp. 313-24.

Euromoney, June 1996, Cwer Story.

Folkers-Landau. David, and Takatoshi Ito, 1995, "International Capital Markets: Developments, Prospects, and Policy Issues," Womld Economic and Fincuncial Sumeys (Washington: International Monetary Fund).

Glen, Jack D.. and Philippe Jorion, 1993, "Currency Hedging for International Portfolios," Journal of Finance, vol. 48, No. 5. pp. $1865-86$.

\section{CInternational Monetary Fund. Not for Redistribution}


Klein, Thomas, 1992, "Managing External Debt in Developing Countries: Proceedings of a Joint Seminar, Jeddah, May 1990," World Bank Discussion Paper No. 155 (Washington: World Bank).

— 1994, "External Debt Management: An Introduction," World Bank Technical Paper No. 245 (Washington: World Bank).

Kritzman, Mark, 1993, "Optimal Currency Hedging Policy with Biased Forward Rates," Journal of Portfolio Management, Vol. 19, No. 4, pp. 94-100.

Kroner, Kenneth F., and Stijn Claessens, 1991, "Optimal Dynamic Hedging Portfolios and the Currency Composition of External Debt," Journal of International Money and Finance, Vol. 10. pp. 131-48.

Kroszner, Randall S., 1996. "Global Government Securities Markets: Economics and Politics of Recent Market Microstructure Reforms," paper presented at the International Economic Association Conference, Frankfurt, Germany.

Mathieson, Donald, David Folkerts-Landau, Timothy Lane, and Iq̨bal Zaidi, 1989, Managing Financial Risks in Indebted Developing Countries, IMF Occasional Paper No. 65 (Washington: International Monetary Fund).

Miller, Norman, 1995, "Managing Intemational Reserves in Developing Countries," Asian Development Review, Vol. 13, pp. 54-77.

Mishkin, Frederick S., 1996, "Asymmetric Information and Financial Crises: A Develøping Country Perspective" (unpublished, Federal Resene Bank of New York).

National Treasury Management Agency, 1997, "Report and Accounts for the Year ended 31 December $1996^{\prime \prime}$ (Iceland).

Nordman, Tom, 1993, "Management of Foreign Exchange Reserves: Objectives. Constraints, Controls, Resources" (Washington: International Monetary; Fund).

Patrawinolpom, Pichit, 1991, "Effects of Exchange Rates on Debt, Debt Services and Public Debt Management in Thailand in the 1980s," Asian Economic Journal, Vol. 5, pp. 339-55.

Perold, Andre F., and Evan C. Schulman, 1988, "Free Lunch in Currency Hedging: Implications for Investment Policy and Performance Standards," Financial Analysts Journal, Vol. 44, No. 3, pp. 45-50.

Piga, Gustavo, 1995. "In Search of an Independent Province for the Treasuries: How Should Public Debt Be Managed?" Journal of Economics and Business, Vol. 50, pp. 257-75.

Reserve Bank of New Zealand, 1995, Reseve Bank Bulletin (Wellington, New Zealand: The Bank).

Rikkonen, Kaija-Leenar, 1989, "Optimal Currency Distribution of a Central Bank's Foreign Exchange Reseıves," Bank of Finland Discussion Papers, No. 28, pp. 1-62. 
Salomon [3rothers, 1989, Asset and Liability Management: Concepts and Strategies for Monelan' Auborities (New York: Salomon Brothers).

_. 1993. Lnited States Fixed-Income Research. Portfolio Strategy, "Determining a Performance Benchmark for a Ceniral Bank" (New York: Salomon Brothers).

\section{- 1994. Central Bank Seminur (New York: Salomon Brothers).}

Sheng. Andrew, and Yoon-Je Cho. 1993. "Risk Management and Stable Financial Structures for LDCs." World Bank Policy Research Working Paper No. 1109 (Washington: World Bank).

Swedish National Debt Office. 1995, Ammal Repont for Fiscal Yest 1994/5 (Stockholm: Swedish National Debt Office).

Wheeler. Graeme. 1997. "New Zealand's Experience with Autonomous Sovereign Debt Management," Rivk Management for Sotereign Counries (Washington: International Monetary Fund).

World Bank, 1996a, "Offer of Currency Choice for Existing IBRD Currency Pool Loans," IBR Financial Products (Washington: World Bank).

—, 1996b, World Debt Tables 1994-95 (Washington: World Bank).

\section{(C) International Monetary Fund. Not for Redistribution}




\title{
Debt and Asset Management and Financial Crises: Sellers Beware
}

\author{
Michael P. Dooley
}

The analytical framework presented below suggests that there
may be good reasons for most governments to follow the ultraconservative debt management strategy observed in industrial countries. Further research and empirical work is needed to translate the model into policy recommendations. I offer one interpretation that seems to me worth careful consideration.

In practical terms, the government should limit its debt to a homogeneous long-term, domestic currency-denominated liability. Moreover, the government should avoid leverage that is generated, for example, by sterilized exchange market intervention. Implicit or contingent liabilities are particularly important to identify and control. In cases where leverage is useful, for example, most net debtors will want to hold foreign exchange transactions balances; the covariance between assets and liabilities should be exploited to minimize the variance of net worth.

The primary reason for advocating a single class of debt is to avoid an adverse selection problem for sovereign credits. When there is more than one class of creditor and when there is some chance of a default, the expected value of a credit to the creditor depends on his or her bargaining power during recontracting. It follows that as the probability of default rises, "tough" creditors will offer better terms. The problem for debt management in developing countries is that these relatively good terms are easily confused with good terms that are justified by better commitment mechanisms. 
Market prices for alternative debt instruments are not a reliable guide to the risk to the debtor; market prices for a single class of debt are more informative. A straightforward way to exploit this information is to issue only one class of debt.

The debt should be denominated in domestic currency because unpredictable changes in real exchange rates generate large changes in the foreign currency value of government receipts. The obvious problem with a single class of domestic currency debt is that it exposes all creditors to domestic inflation. This is true, but surprise inflation is the likely way that small amounts of foreign currency debt will be serviced in any case. Most countries will not find it optimal to denominate all their debt in foreign currency. Partial commitment to price stability is no commitment at all. Foreign currency debt shifts the inflation tax to remaining domestic currency debt or to some other class of less easily observed liabilities.

It follows that the main job of portfolio management policy is to minimize the chance that the marginal contribution of debt is mispriced from the point of view of the debtor. Long-term domestic currency debt seems to be the best vehicle from this perspective.

\section{Debt Management in Industrial and Developing Countries}

Setting out a theory of optimal asset and liability management for governments of developing countries is a challenge. There are at least two reasons why we cannot take analytical tools developed for debt management policy in industrial countries "off the shelf" and apply them to emerging economies. First, if we ignore default, there is litthe agreement in the literature about the optimal level of debt, what type of debt government should issue, and what role, if any, government should play in financial intermediation. Second, even if we could agree upon the "right" model for industrial countries, there are good reasons to believe that the uncritical application of the model to emerging markets, where default is an option, would be a mistake.

The experience of industrial countries is also an uncertain guide. Industrial countries have followed conservative debt management policies. As financial innovation has changed the nature of private financial markets, industrial country governments have, for the most part, chosen to continue to issue fixed-interest securities and to hold 
a narrow range of financial assets, of ten composed of securities issued by other governments. Industrial countries have also been cautious in acquiring contingent liabilities in the form of guarantees of private debt. An important exception is deposit insurance, but even here they have been careful to control the risk associated with such commitments. There might be good reasons for this conservative approach, but it might also be the case that debt management "rules of thumb" were developed in an era when international and derivative markets were quite limited; inertia might account for debt managers' apparent lack of imagination.

Debt management policies for governments of emerging markets are less constrained by tradition and the presumption that the government should avoid the more exotic corners of the financial markets. In fact, participation in a richer set of debt management techniques seems natural in an environment in which hedging activities and risk management are seen as a responsibility of any economic entity with significant assets and liabilities.

While industrial countries have not deviated much from a traditional approach, economists have discussed a number of theoretical arguments for welfare improving departures from the conventional policies. To begin to build a framework for evaluating the options for developing countries, we can build on an understanding of lessons drawn from this literature. Some of the important papers in this literature are cited in the references; in this paper, only a few of the arguments that seem to be important for emerging markets are highlighted.

The story that emerges from this literature is that optimal debt management policies can, in principle, mitigate distortions to first best competitive equilibria. If distortions differ across countries, so will the implied debt management policy. Recent contributions to the literature emphasize the possibility of self-fulfilling expectations, and these models suggest quite different implications for debt management.

Economists have a difficult time in considering more than one distortion at a time. This paper develops the idea that losses in output that follow government default is the distortion that "should" dominate debt management policy in emerging economies. The reader should remember that there is little in the way of empirical evidence that would allow a ranking of distortions according to the welf are losses they generate or the ability of debt management policy to amplify or mitigate these losses. 


\section{Overview of Debt Management Policy and Plan of Study}

Debt management policy regulates three distinct characteristics of a government's balance sheet. These are the government's net debt, its stock of gross debt and gross assets, and the composition of its assets and liabilities. Changes in the net debt of the government are generated by fiscal deficits and by capital gains and losses on assets and liabilities. Stocks of gross assets and liabilities are independent of the net position (a given level of net debt or net assets determines the difference between gross assets and liabilities but not their level) and are important because leverage alters the expected returns and the variability of net wortl. One way to measure leverage is the ratio of gross assets to net werth. A convenient way to think about the composition of assets and liabilities is to measure change in net worth that results from changes in variables such as interest rates or exchange rates. Exposure of the portfolio clearly depends on changes in the value of individual assets and liabilities and the covariance of changes. We call this the economic exposure of the portfolio.

In the next section, a variety of theoretical arguments relevant for debt management policy are reviewed. The objective is to carefully set out how management of the government debt "affects" welfare. The "easy" place to start is a neoclassical model in which debt management policy is powerless to affect equilibrium values of economic variables. Modifications of the neoclassical model introduce distortions to a first best equilibrium that might be corrected through debt management policy. Some of these are familiar. Distortions to labor and capital markets imply that net debt management might help smooth fluctuations in output. If taxes are distortionary or costly to collect, an optimal path for net debt will generally involve some smoothing of tax rates over time.

Distortions that might favor alternative types of government debt and asset portfolios, and the leverage of those portfolios, are less familiar but may be more relevant for debt management policy. While many potential distortions have been examined in the literature, this paper considers only a subset that is likely to be important for emerging markets. ${ }^{1}$ The more important models focus on the effects of incomplete financial markets, time consistency of government policy. multiple equilibria, and political markets for distributional shares.

:For an excellent review of the formal literature, see Missale (1994).

\section{CInternational Monetary Fund. Not for Redistribution}


Later, we go on to develop the idea that, while these models are interesting and informative, the distortion most likely to be important to developing countries is not explicitly considered in the context of industrial countries. For emerging economies, a dominant distortion has been the loss in output and growth that has followed financial crises.

At the end, we explore the distinction between the portfolio that is managed and the much larger portfolio to be optimized. Although only a subset of the government's assets and liabilities are actively managed, sensible debt management policy is concerned with the value of the entire portfolio and the effects of changes in its value on residents' welfare. The widespread practice of establishing a "benchmark" portfolio for foreign currency-denominated assets and another benchmark portfolio for foreign currency-denominated liabilities seems likely to violate this fundamental rule. Benchmark portfolios are usually derived from historical relationships between levels and variability of yields on the set of instruments included in the portfolio. Dooley, Lizondo, and Mathieson (1989) show that the straightforward merging of asset and liability portfolios for developing countries provides a much different picture for what countries are accomplishing and should be trying to accomplish by managing the currency composition of their financial assets and liabilities. The problem with separating asset and liability portfolios is that there is a perfectly predictable covariance of minus one between the value of otherwise similar assets and liabilities denominated in the same currency.

But considering financial assets and liabilities together clearly does not go far enough. Domestic currency debt is also an important part of many governments' portfolios. Moreover, governments have one dominant asset: future tax receipts. There is no practical way to manage this asset except in rare cases where revenues from oil or another commodity can be hedged. Markets for future tax receipts simply do not exist. It follows that a government with one dominant undiversified asset may not find it optimal to diversify its net financial liabilities.

\section{Debt Management Policy}

Management of net debt is straightforward if Ricardian equivalence holds. The key assumption in this class of models is that the 
government debt is treated by taxpayers as if it were their own. ${ }^{2}$ Government spending matters for household behavior but the time profile of taxation and borrowing does not. Any pattern of taxes and borrowing that does not lead to insolvency is optimal because a representative, perpetual household anticipates future tax burdens and hedges its exposure by adjusting private savings.

It should be noted that taxes are special in the conventional model in that it is assumed that the government will manipulate tax rates (or government spending) in order to honor its net debt. The expected present value of conventional net tax receipts is the principal asset that the government holds. Perhaps we can think of this as an assumption that a well-defined set of taxpayers have an equity position in the government - in that they hold the residual asset or liability position. If the effective tax rate is bounded by either political or economic constraints, it is clear that in some circumstances the value of net liabilities can exceed the present value of net taxes and the value of some liability will have to be reduced. We will refer to the allocation of losses across net nontax liabilities as a crisis and the reduction in the value of alternative liabilities as a default. The standard assumption in the context of industrial countries is that surprise inflation is the relevant default technology available to the government.

\section{Net Debt Management in an Imperfect World}

Empirical work seems to be quite hostile to the idea that the private sector systematically offsets changes in the government's net debt. ${ }^{3}$ Moreover, there are several theoretical frameworks in which government deficits do matter. Blanchard, Dornbusch, and Buiter (1986), for example, present an intertemporal model in which deficit finance can make an important contribution to stability and growth. For the purposes of this paper, the implication is that net debt management policy is likely to be dominated by concerns about economic stability.

\footnotetext{
2See Barro (1979).

3Tobin (1971) provides sophisticated reasons for believing that changes in the stock of net debt and its composition matter for the timing of consumption and investment. In particular, tax liabilities are uncertain and not traded while government bonds are liquid assets to the holder.
} 
Nevertheless, the stock of net debt is an important problem for the debt manager. As the stock of net debt (or net assets) rises or is more highly leveraged, capital gains and losses on that net position become more important relative to the flow of fiscal deficits in generating changes in the government's net worth. The working assumption for this paper is that stabilization policy is, or at least is thought to be, too important to be delegated to a debt manager. We focus, therefore, on the management of the portfolio.

\section{Portfolio Management Policy}

A time path for net debt restricts the difference between the expected present value of the government's assets and liabilities at each point in time but does not restrict the scale of the government's portfolio of gross assets and liabilities or the composition of either gross assets or liabilities. For convenience, we will refer to the management of gross assets and liabilities (both on and off balance sheet) given net debt as "portfolio management policy."

There are two issues to be resolved. The first is the optimal leverage of the portfolio. The second is the composition of the portfolio. Some readers will find it useful to think of the government as a financial intermediary that inherits a net worth position, issues liabilities to acquire assets, and manages the economic exposure of assets and liabilities to maximize a risk-return trade-off. The intermediary also manages of $\mathrm{f}$ balance sheet risks in order to protect its net worth.

The counterpart to Ricardian equivalence for net debt is a "Modigliani Miller" theorem for the scale and structure of gross debt. The conditions under which this neutrality result holds have been carefully set out in the literature. ${ }^{\dot{ }}$ If there is no uncertainty, and if representative, perpetual households consider the government's portfolio their own, it seems clear that any gross position the government takes would be fully offset by the private sector.

With uncertainty, the private sector must also offset the expected variability of their net tax liabilities generated by changes in the market value of the government's portfolio. For example, if the government takes a highly leveraged position by issuing domestic cur-

"See Stiglitz (1983) and Chan (1983). 
rency debt in order to acquire foreign currency assets, the private sector would have to be able to offset the government's position in the same or equivalent markets. This is the basic reason why sterilized intervention, or any other changes in the economic exposure of the government's portfolio, has no economic effects in a "neoclassical" model.

One of the many strong assumptions necessary for this result is that households must be able to forecast their share of taxes associated with the government's capital gains and losses, as well as the gains and losses on their share of government liabilities. Clearly, the household cannot manipulate its portfolio to offset its contingent tax liability if it does not know what that tax liability will be. ${ }^{5}$

\section{Portfolio Management in an Imperfect World}

If the private sector does not seem to offset net government debt, it seems even less likely that gross positions are systematically offset. If, for a variety of reasons discussed below, the private sector cannot offset the exposure and leverage of the government's portfolio, portfolio management policy can contribute to or detract from residents' welfare.

\section{Incomplete Markets}

One of the more interesting distortions emphasized in the literature is associated with incomplete credit markets. By issuing various "new" types of debt, the government can provide vehicles that allow the private sector to increase welfare. In some cases, the new asset allows trade between generations. ${ }^{6}$ In others, the new asset has a desirable covariance with risks that cannot be hedged using existing markets. ${ }^{7}$ The idea is that, once established, a liquid market for a new asset, such as a fixed interest nominal bond of varying maturities, provides free information about market expectations to the private sector. Since the information is free to all, there may be underinvestment without government intervention. If such debt re-

SSee Fischer (1983).

osee Gale (1990).

'See Bohn (1988), (1990a), and (1990b) for models that evaluate different types of government debt, including foreign currency-denominated debt. 
ally is useful to the private sector, then investors will hold it at a lower yield. This suggests that minimizing debt-service costs is a good indicator that the government is providing welfare-improving debt instruments.

For emerging markets, it seems likely that this argument is relevant for optimal portfolio management policy. Emerging markets lack many of the financial markets that are potentially useful to the private sector. For example, the development of a liquid market for long-term, fixed-interest government debt may fill an important gap in the ability of residents to finance long-term investment.

\section{Credibility}

Another interesting class of models points to debt management as a way for the government to commit to utilize conventional taxes rather than surprise inflation to satisfy the government's budget constraint. ${ }^{8}$ The government can commit price stability by issuing assets and liabilities that would not benefit from surprise inflation. This idea seems particularly relevant as the stock of debt grows as it has recently in several European countries.

These models imply that the government can reduce real debtservice costs by shortening the maturity of domestic currency debt, indexing returns to inflation, or replacing domestic currencydenominated debt with foreign currency debt. This is clearly at odds with the idea that the government should develop a long-term domestic bond market to complete the market. But we are not done with this issue yet. In the next section, we review an important reason to lengthen the maturity of domestic currency debt.

\section{Multiple Equilibria}

The lesson from the previous section is that private expectations concerning future inflation determine this period's debt-service costs if the government issues debt that is subject to the inflation tax. This raises the possibility that changes in private expectations can quickly generate a crisis in the sense that market interest rates on short-term debt can rise quickly and call into question the govemment's willingness and ability to finance debt-service obligations.

${ }^{8}$ See Lucas and Stokey (1983). 
These shifts in private expectations can, in some cases, lead to multiple equilibria and self-fulfilling expectations of high rates of inflation. 9 Calvo (1988) summarizes the implications of the argument as follows: "The implications for policy could be staggering: for our results suggest that postponing taxes (i.e., falling into debt) may generate the seeds of indeterminacy; it may, in other words, generate a situation in which the effects of policy are at the mercy of peoples' expectations-gone would be the hopes of leading the economy along an optimal path." If there are real costs associated with financial crises, the government should avoid short-term domestic debt and spread refinancings evenly over time. In this context, lengthening maturity minimizes the chance that the debt will have to be rolled over just when expectations are at a bad point. ${ }^{10}$

There is an obvious conflict here. The inability to commit to low inflation means that the private sector will not give up its option to alter the inflation risk premium by buying long-term bonds unless they are induced to do so by a steep yield curve. But the possibility of a shift in private expectations means that government should avoid relatively cheap short-term debt if it wants to avoid a crisis.

\section{Default Risk}

While inflation is clearly a default option for developing countries, we have considerable evidence that outright default on some types of financial obligations is also an option. Even countries that have never defaulted are exposed to expectations that such an option is available. This additional option makes portfolio management for emerging markets more difficult and more important. Any debt management policy must be evaluated for its contribution to probability that a default will occur and for the costs of the default if it does occur. The universal assumption that inflation is the relevant default technology for industrial countries is consistent with the idea that alternative types of default are too costly to deserve serious consideration. ${ }^{11}$

9See Calvo (1988); and Calvo and Guidotti (1990).

10See Giavaz7i and Pagano (1990).

11 ln the literature, default is generally referred to as a capital levy. A one-time surprise tax on holders of debt is equivalent to a default on that debt. Capital 
While this is a more important issue for large net debtors, even countries with modest net indebtedness should avoid capital losses that might reduce net worth to levels that make insolvency a possibility. Open economies are subject to shocks from commodity prices, real exchange rates, international interest rates, and losses in their domestic banking systems. When combined with highly leveraged structures of financial assets and liabilities, these shocks can generate capital gains and losses for the government that call into question their ability and willingness to roll over their financial obligations on market terms. In the remainder of the paper, we develop the implications of this possibility for debt management policy.

An analogy with the earlier discussion of fiscal policy might be useful. It was argued above that the welfare effects of net debt management were too important to be entrusted to debt managers. In this section, we develop the view that the natural preference of debt managers for maximizing returns on assets and ninimizing costs of debt service should be subjugated to a more important objective. If financial crises are costly, debt and asset management should focus on one objective: avoiding capital losses that call into question the government's willingness and ability to roll over existing debt on market terms.

Developing countries have defaulted on both internal and external debt. Further, developing countries have defaulted differentially on "domestic" and "foreign" debt and have defaulted differentially on different types of debt within these two classes. This makes the analysis of optimal debt management much more difficult for developing countries. Private investors have to consider the possibility of surprise inflation and devaluation, but also must consider the possibility of outright default. This makes the market yield on internal and external debt highly interdependent. For this reason, the distinction between internal and external debt for developing countries has lost much of its meaning. As residents of developing countries have gained access to international credit markets, they have chosen to hold their government's foreign currency-denominated debt. In recent years, it has become common for nonresidents to hold developing country governments' domestic currency debt.

levies were extensively discussed as an option for reducing the large debts accumulated during World War II. See Eichengreen (1990) for an excellent discussion of the economics and political economy of this era. 
To start to understand debt management in such a world, Dooley and Stone (1993) developed a model of "implicit seniority" to understand why governments are able to borrow at different interest rates even when payment on all classes of debt comes from the same expected stream of government revenue. In their paper, they argued that it is difficult for the government to credibly commit in advance to treat one class of creditors better than another. If some default will be necessary in some states of the world, it is reasonable to assume that the government at that time will opt for the least costly form of default. There are a long list of options. Since the government will certainly consider the whole list when trouble comes, lenders will consider their relative standing in different states of the world when setting the terms on alternative instruments.

A positive theory of the government's choice of default would simply be that it is unable to commit before the event to any rule and, after the event, minimizes the losses and penalties associated with each option. We can say a few things about this process. First, the revenue gained from a given rate of default depends on the tax base or the initial size of the position. It is often argued, for example, that foreign currency sovereign bonds are safer than other forms of debt. We suspect this is simply because international bond issues have been small as compared to domestic debt and alternative international debt. If there are fixed costs to default, rational governments would avoid defaults that yield little income.

The interdependence of the value of sovereign debt suggests an important and somewhat counterintuitive problem for portfolio management in emerging markets. The marginal contribution of a given asset or liability to the risk faced by the government will normally appear in the market valuation of other assets and liabilities. Suppose, for example, that the accumulation of foreign currenc $y$ denominated debt, and retirement of domestic currency debt, exposes the government to a capital loss that the market considers quite likely. But suppose also that in the event the loss occurs, foreign currency debt will be first in line for payment. The incidence of the expected loss might fall, for example, on entitlements for older residents. The fall in the market value of these entitlements will he difficult to observe. Moreover, we have little faith in the view that residents will immediately increase their own retirement savings although the tendency for this response is clear enough. So the government faces a difficult task. A simple lesson is that if the present 
value of expenditures is not affected by changes in the terms of trade, then the present value of debt should also not depend on terms of trade. In short, domestic currency debt is the preferred financial obligation. If the government wants to hold some foreign exchange assets for liquidity, it should hedge these with a foreign currency debt.

But why would the "market" accept the counterparty risk associated with a government that might become insolvent? If a small subgroup of creditors believes that they will do well in states of the world where the government becomes insolvent, it might be in their interest to offer risky positions (to the govemment) at low-risk premiums.

\section{Policy Toward Instruments and Creditors}

A general way to express this result is that the government must be concerned both with the contribution of a credit to the probability that some creditor group will find it in their narrow interest to refuse to roll over debt, thereby forcing a renegotiation, and the contribution of that creditor group to the bargaining that will occur following a default. The optimal strategy for a sovereign "manager" is to choose a debt portfolio (rather than an optimal contract) that on the one hand makes strategic default unattractive, but on the other hand attempts to minimize the damage associated with bargaining that will follow an unavoidable default.

A portfolio that makes a strategic default unattractive would allow for frequent calls for rescheduling probably through short maturities and rescheduling that would be costly to the government. If the probability of a bad state is zero, the government will simply choose the portfolio that generates deadweight losses to itself following a strategic default that equals the payment necessary to generate a competitive rate of return for the creditor. This is a form of comnitment that makes lending possible. In the sovereign debt case, high deadweight loss credit structures are associated with "slow" settlement. But as the probability of a bad state rises, the optimal debt structure involves quick settlement so that the creditors get some payment before the investment depreciates.

If the only observable difference between the two types of defaults is the liquidity of the government, then the crucial point is the ability of the government to buy back its debt following a strategic 
default. Clearly the government would want no buyback rules for commitment. But in an unavoidable default, this would make settlement more difficult.

Countries with little or no risk of an unavoidable default will favor debt structures that ensure maximum punishment following a strategic default. The problem in both the corporate and sovereign cases is to determine how different numbers or types of creditors atfect the optimal debt structure. The corporate case proceeds as follows. All the managers, potential managers, creditors, and potential creditors look forward to the bids that each will make following a seizure of the firm's assets. The composition of debt "matters" under any set of assumptions where the value of the asset to individual participants in this game depends on the behavior of the other participants. Bolton and Scharfstein (1996) assume that new managers earn lower returns on the asset and incur costs of evaluating the assets. To distinguish between one and many creditors, they also assume that each creditor has the right to seize a well-defined asset and that these assets are worth more when used together than separately. The ability of a creditor to block coalitions that can best utilize the seized asset provides the result that the number of original creditors "matters" for the expected value of the investment to the initial manager.

The structure of the game that determines the equilibrium for different debt structures is quite specific to the assumptions that seem appropriate for corporate finance. These assumptions do not travel well to the case of sovereign debt. But the intuition we want to pursue for the case of sovereign debt does emerge in this formal model. In general, the government and the corporate "manager" must consider both the contribution of a given debt structure to the probability that a default specified in the optimal contract-and the costs of that default should it occur.

The key assumption that makes the model interesting is that which ensures that conflict resolution generates deadweight losses for all the participants. In the corporate finance model outlined above, this is a static problem in which the salvage value of the company's assets depends on the structure of debt. For sovereign debt, it seems natural to model the deadweight losses that result from the passage of time during which the creditors and debtors argue about the division of future income. During this interval, we will assume that the ability of anyone to utilize the asset is impaired. 
Thus, we have a coordination problem that is related to the structure of the debt. This can be modeled as a war of attrition (Drazen and Grilli, 1993) where creditors' uncertainty about the attributes of other creditors generates delay in settlement.

In applying these ideas to the sovereign debt case, we are both more and less ambitious. We are less ambitious in that we will not try to solve for an optimal contract but assume that the government chooses among a limited set of conventional contracts in order to assemble the optimal debt portfolio. We are more ambitious in that we attempt to describe the incentives for repayment in a new manner.

The existing sovereign debt literature has interpreted the fact that seizure of assets is impossible as suggesting that the punishment for nonpayment is unrelated to the assets acquired through the issue of debt. This makes the corporate debt literature of little direct use. The lack of collateral or the means to seize it means that some alternative threat is necessary to provide an incentive for repayment. The typical threats that have been modeled involve trade sanctions or prohibition of future borrowing. The trouble with these enforcement mechanisms is that the former has never been observed and the latter seems weak relative to the amount of debt observed. Moreover, if countries had the ability to impose such sanctions, they should do so regardless of the debt.

The assumption is that nonpayment triggers the "right" to impose these sanctions that are always in principle desirable. This has proven to be a useful assumption, but here I propose alternative ad hoc assumptions that seem to me more useful as a way to understand sovereign debt management. The main feature of this specification is that the threat available to creditors is the ability to block the use of assets acquired by the debtor government. The threat obviously evaporates as the assets depreciate. This provides an end to the recontracting game that seems more consistent with experience. Sovereign debt reschedulings are eventually resolved.

\section{A Sovereign Debt Model}

Assume a world that lasts for three periods. In the first period, a foreign creditor lends the government $K$ to buy some assets where 
$K$ is a dollar amount. The risk-free interest rate is assumed equal to zero.

The government uses $K$ to import an asset that in the second period yields $x$ with probability $\Theta$ and zero with probability $1-\Theta$. The government can also import unproductive assets that yield zero. This behavior is not observable by the creditor. The asset lasts for one more period but depreciates uniformly during the period and yields a certain return $y$. The government agrees to pay $Z$ in the second period. If the government pays less than $Z$, the creditor has the right to impair the government's use of the asset until a new agreement is reached for a share of the residual value of the asset, $y$.

During the third period, the asset cannot be used by the government if a negotiation for sharing $y$ is in progress. The value of the asset declines during the third period from $y$ to zero. This specification of the punishment technology is appealing because it means that the creditor(s) is only able to interfere with the government's ability to utilize the assets acquired with the foreign funds and for only as long as the assets last. The alternative interpretation that the creditor(s) can punish the debtor forever and without regard to the scriousncss of the offensc is lcss appcaling. Onc might think of a subsistence economy lifted temporarily to a higher level of output by an infusion of foreign capital, but once the capital depreciates, the creditor has no way to push output below the initial level.

If the government can pay, which occurs with probability $\Theta$, it will consider a strategic default. The temptation to keep $z$, the contractual payment in period 2, is compared to the value of $y$ that the government expects to capture following a negotiation with the creditor(s). The incentive constraint for the government to pay $z$ if $x$ occurs is:

$$
z<y-g y t_{s},
$$

where $g y t_{s}$ is the expected share of $y$ that goes to the government following a negotiation lasting $0<t_{s}<1$.

The value of strategic default depends on the expected duration of the negotiation in period 3. If the government cannot pay, which happens with probability $(1-\Theta)$, there is a similar negotiation. The difference is that following a strategic default, the government has "secret" resources that can be used to overcome the coordination problem and speed a settlement. The creditor must expect to make a fair rate of return: 
$\Theta(z)+(1-\Theta) c y t_{b}-K=0$

where $c y t_{b}$ is the share of $y$ that goes to the creditor following an unavoidable default. Note that $g y, c y, t_{s}$, and $t_{b}$ are a complicated function of the structure of debt and that $t_{s}$ will generaily not be equal to $t_{b}$.

The problem for the government is to design a debt structure that maximizes its net revenue from investment. The general form of the government's net revenue function is:

$\Theta(x-z)+(1-\Theta) g y t_{b}=R$.

Substituting (1) and (2) into (3), we arrive at:

$$
R=\Theta x+y-K-(1-\Theta) y t_{b} \text {. }
$$

The first three terms of (4) are the first best expected return on the asset if there is no default. The fourth term is the deadweight loss associated with rescheduling. A full description of how a portfolio of debt might be designed to maximize the expected value of (4) is difficult. Analytic and simulation solutions for this problem are topics for future research. In principle, the key parameters could be estimated from data on how long it takes to renegotiate different debt structures and how costly the renegotiation is. A result that stands out, however, is that the optimal portfolio is clearly related by the probability that the investment will fail for reasons beyond the control of the debtor government.

At the start of the third period, it might be natural to assume an immediate meeting of the minds. Clearly if there is one creditor and one debtor, they might assess each other's bargaining power and rather than watch the asset melt will divide the spoils. ${ }^{12}$ However, if the two sides are uncertain about the other's preferences or have different expectations about a "fair" division, some waiting and deadweight losses are likely. The equilibrium condition is that each creditor and, if not liquidity constrained, the debtor compares the marginal cost of waiting with the marginal benef it of winning. The benefit is the probability that the other side will concede in the next instant times the difference between the winner's and loser's share of what remains of the asset. If there are a "few" creditors, they will

I2This type of bargaining is assumed, for example, in Bulow and Rogoff (1989). In that model, the adversaries evaluate one another and immediately agree to a payment. 
have to assess the others' expected returns for delaying a settlement. If there are many creditors, it might be difficult to arrange any agreement for a long time.

It is important to remember that the actual coalitions that emerge following a default may be difficult to predict, and the behavior of coalitions may be difficult to predict. A natural assumption is that classes of liabilities - for example, all foreign currency-denominated liabilities—would be natural attractors for a coalition. But foreign currency-denominated bondholders might find it in their interest to be free riders on an agreement between other large creditors. It follows that the number of types of liabilities issued might not be a good predictor of the number of coalitions that would form following a default.

An important aspect of the problem facing the government is that alternative credits cannot be evaluated according to the explicit contractual terms since these are only relevant in nondefault states of the world. Moreover, credits or creditors cannot be evaluated according to their marginal contribution to the probability that a default will occur. Once default is a possibility, a credit influences the probability that a default will occur-and the expected cost to the debtor, and the deadweight loss suffered by the debtor associated with adding that credit to the bargaining game.

The difficulty of evaluating the welfare implications of aiternative debt structures is illustrated by the substitution of dollar-indexed, short-term debt (tesobonos) by the government of Mexico for shortterm domestic currency debt (cetes) in the months leading up to the December 1994 crisis. The existing literature on debt management would emphasize the fact that by indexing the liability, the government altered its incentives to inflate and devalue the currency. Thus, the probability that a default in the form of inflation and devaluation would be optimal was reduced. Our model emphasizes a different aspect of the same policy. The substitution of tesobonos for cetes changed the nature of the rescheduling exercise that followed the 1994 crisis. The recontracting in this case was resolved quickly by forceful intervention by official creditors. In retrospect, the issue of tesobonos was a good idea if the decision of official creditors, in this case the U.S. government and international organizations, to lend quickly and in large amounts was due to their unwillingness to fight a long costly war with a well-organized and powerful group of holders of tesobonos. 
A reasonable conjecture is that creditors that expect to do well in the bargaining game are those best positioned to delay settlement. Other things being equal, such creditors will offer relatively good terms as the probability of default rises. Because the tough bargainer does not internalize the deadweight loss that it will impose on others, assumed market prices are distorted and are a misleading guide for the government. In fact, as default becomes more likely, a debtor might be tempted to choose debt that minimizes the probability of a default in that it offers reduced contractual payments. This would be a mistake if this type of debt was associated with high costs to the debtor if the default occurs.

It might be optimal to create as few instruments and classes of creditors as possible. If there are no "niches" in which particularly hostile creditors can gather, they might self-select out of the credit supply. The industrial countries have adopted just such a rule. In general, industrial country governments issue one class of liabilities with a range of maturities but with no implicit or explicit seniority among credits or creditors.

\section{Why Domestic Currency Debt?}

The above discussion suggests that the debt manager might want to limit the ability of interest groups to form by issuing only one type of debt. But the analysis does not help determine what type of debt would be best. In our view, the dominant consideration is governments' limited ability to generate changes in the foreign currency value of tax revenue. It follows that governments cannol afford to issue foreign debt, or more precisely foreign currency-denominated debt, even if that debt helps commit the government to price stability. ${ }^{13}$ Foreign currency debt exposes the government to changes in its net worth resulting from changes in the real exchange rate. As far as we know, these real exchange rate changes are unrelated in a statistical sense to other changes in the government's wealth.

Even small amounts of external debt can be costly, not because a developing country will choose to default on its external debt, but because external debt service can increase when the foreign cur-

${ }^{13}$ An exception would be a credible currency board as might evolve, for example, in Argentina. In this case, the exchange rate risk has been eliminated so it makes sense to issue foreign currency liabilities. 
rency value of government revenues falls. This often induces the government to default on its internal debt through inflation. Residents' expectations of this reaction generate the extraordinary increases in domestic real interest rates and capital flight that precede financial crises in developing countries.

\section{Is Default Risk a Problem for Countries With Reserve Assets?}

Industrial country governments have generally been conservative in leveraging their portfolios because they are quite sensitive to the political problems associated with capital gains and losses generated by highly leveraged positions. For example, the relative unwillingness of the government of the United States to intervene in foreign exchange markets is partly explained by the unwillingness of the Treasury and Federal Reserve to accumulate reserve assets that fluctuate in value relative to the domestic currency debt that necessarily finances such accumulations.

Developing country governments have been much more inclined to leverage their positions. Sterilized intervention has created large asset and liability positions that are sensitive to exchange rate changes. Moreover, governments in developing countries are probably more exposed to capital gains and losses than they realize. At a minimum, governments that manage exchange rates must consider the implicit liability to guarantee the domestic currency value of assets and liabilities in the domestic banking system. If a government decides to liberalize its domestic credit markets, prudent debt management policy would immediately recognize an implicit liability that will arise if important institutions prove not viable in this new environment. If the insured institutions are sensitive to increases in international interest rates, it is important that the government's other liabilities not be sensitive to these factors.

\section{References}

Alesina, Alberto, and Allan Drazen, 1991, "Why Are Stabilizations Delayed?" American Economic Reriew, Vol. 81, pp. 117-88.

Alesina, Alberto, and Roberto Perotti, 1995, "Political Economy of Budget Deficits," IMF Staff Papers, International Monetary Fund, Vol. 42 (March), pp. 1-31. 
Barro, Roberto, 1979, "On the Determination of Public Debt," Journal of Political Economy, Vol. 87 (October), pp. 940-71.

Blanchard, Olivier, Rudiger Dombusch, and Willem Buiter, 1986, "Public Debt and Fiscal Responsibility, in Resroring Europe's Prosperity, ed. by Olivier Blanchard et al. (Cambridge, Massachusetts: MIT Press), pp. 125-53.

Bohn, Henning, 1988, "Why Do We Have Nominal Govemment Debt?" Journal of Monetary, Economics, Vol. 21 (January), pp. 127-40.

, 1990a, "Tax Smoothing with Financial Instuuments," American Economic Review, Vol. 80, No. 5 (December), pp. 1217-30.

_ 1990b, "Positive Theory of Foreign Currency Debt." Journal of Internarional Economics, Vol. 29 (November), pp. 273-92.

Bolton, Patrick, and David Scharfstein, 1996, "Optimal Debt Structure and the Number of Creditors," Journal of Political Economy, Vol. 104, No. 1 (February), pp. 1-50.

Bulow, Jeremy, and Kenneth Rogoff, 1989, "A Constant Recontracting Model of Sovereign Debt," Journal of Political Economy, Vol. 97 (February), pp. 155-78.

Calvo, Guillermo A., 1988, "Servicing the Public Debt: The Role of Expectations," American Economic Review, Vol. 78, No. 4 (September), pp. 647-61.

_, and Pablo E. Guidotti, 1990, "Indexation and Maturity of Government Bonds: An Exploratory Model," in Public Debt Management: Theory and History, ed. by Rudiger Dornbusch and Mario Draghi (Cambridge, England: Cambridge University Press), pp. 52-93.

Chan, Louis K.C., 1983, "Uncestainty and the Neutrality of Government Financing Policy," Journal of Monetary Economics, Vol. 11, pp. 351-73.

Dooley, Michael P., 1995, "A Retrospective on the Debt Crisis," in Understanding Interdependence: The Economics of the Open Economy, ed. by Peter Kenen (Princeton: Princeton University Press).

_ José Saúl Lizondo, and Donald Mathieson, 1989, "The Currency Composition of Foreign Exchange Reserves," IMF Staff Papers, International Monetary Fund, Vol. 36, No. 2, pp. 385-434.

Dooley, Michael P., and Mark Stone, 1993, "Endogenous Creditor Seniority and External Debt Values," IMF Staff Papers, International Monetary Fund, Vol. 40, No. 2, pp. 395-413.

Drazen, Allan, and Vittorio Grilli, 1993, "The Benefits of Crises for Economic Reforms," American Economic Review, Vol. 83, No. 3 (June), pp. 598-607.

Eichengreen, Barry, 1990, "The Capital Levy in Theosy and Practice," in Public Debt Management. Theory and History, ed. by Rudiger Dornbusch and Mario Draghi (Cambridge, England: Cambridge University Press), pp. 191-215.

\section{(C) International Monetary Fund. Not for Redistribution}


Fischer, Stanley, 1983, "Welfare Aspects of Government Issue of Indexed Bonds," in Inflation, Debt, and Indexation, ed. by Rudiger Dornbusch and Mario H. Simonsen (Cambridge, Massachusetts: MIT Press), pp. 223-46.

Gale, Douglas, 1990, "The Efficient Design of Public Debt," in Public Debt Management: Theory and History, ed. by Rudiger Dornbusch and Mario Draghi (Cambridge, England: Cambridge University Press).

Giavazzi. Francesco, and Marco Pagano, 1990, "Conlidence Crises and Public Debt Management," in Public Debt Management: Thevry and History, ed. by Rudiger Dornbusch and Mario Draghi (Cambridge, England: Cambridge University Press), pp. 94-124.

Lucas, Robert E., and Nancy L. Stokey, 1983, "Optimal Fiscal and Monetary Policy in an Economy Without Capital," Journal of Monetary Economic.s, Vol. 12, pp. 55-94.

Missale, Alessandro, 1994, "Public Debt Management," mimeo (Cambridge, Massachusetts: MIT Press).

Pagano. Marco, 1988, "The Management of Public Debt and Financial Markets," in High Public Debt: The Italian Experience, ed. by Francesco Giavazzi and Luigi Spaventa (Cambridge, England: Cambridge University Press), pp. $135-76$.

Peled. Dan, 1984, "Stationary Pareto Optimality of Stechastic Asset Equilibria with Overlapping Generations," Joumal of Economic Theory, Vol. 34, pp. $396-403$.

Stiglitz, Joseph E., 1983, "On the Relevance or Irrelevance of Public Financial Policy: Indexation, Price Rigidities, and Optimal Monetary Policies," in Inflation Debt and Indexation, ed. by Rudiger Dornbusch and Mario H. Simonsen (Cambridge, Massachusetts: MIT Press), pp. 183--222.

Tobin, James, 1963. "An Essay on the Principles of Debt Management," in Fiscal and Debt Management Policies, ed. by William Fellner and others (Englewood Cliffs, N.J.: Prentice-Hall). Reprinted in James Tobin, 1971, Essays in Economics, Vol. 1 (Amsterdam: North-Holland). 


\section{Comments on Dooley}

\section{Philippe Jorion}

The paper by Michael Dooley provides a useful overview of the theory of sovereign asset and liability management (ALM). Countries face a wide menu of choices for their debt. At the most basic level, their choices consist of domestic currency-denominated versus foreign currency-denominated debt, and floating rate versus fixed rate debt. At a more advanced level, they also have to choose the foreign currency to borrow in and whether to enter currency swaps, interest rate swaps, and possibly commodity swaps.

Professor Dooley basically concludes that the main consideration in structuring sovereign ALM is avoiding default; hence, sovereign debt should be issued only in domestic currency-denominated longterm debt. My comment will attempt to bring a different perspective to the matter. First, it will review the various theories expounded; and second, it will discuss whether the emphasis on default is appropriate.

\section{Review of Models}

\section{Neoclassical Model}

The neoclassical model provides a useful starting point. Assuming no uncertainty, complete financial markets, and that taxpayers view the government portfolio as their own, debt policy is totally irrelevant.

This is an extension of the "Modigliani-Miller" irrelevance theorem, which states that in perfect markets, the financing decisions of corporations are irrelevant since investors can costlessly "undo" any corporate financing policy they do not like. Thus, if taxpayers can undo government actions and if there is no cost of default, the mix of government borrowing and taxation is irrelevant as taxpayers rationally focus on government spending only.

The neoclassical model, however stylized, brings to the fore the role of market imperfections. Depending on the type of distortion one focuses on, different optimal debt policies arise. 


\section{Incomplete Markets}

The first class of distortions consists of incomplete financial markets. Here, Michael Dooley considers two classes of incompleteness.

In the first, there is no market for long-term debt, thus making it impossible for investors and borrowers to exchange fixed long-term nominal liabilities. The government can then improve this situation by creating a market for long-term debt. It should be noted, however, that this could also be achieved (and probably more efficiently) by facilitating a market for long-term corporate debt or equities.

The other argument is that domestic currency debt can serve as a hedge against fluctuations in output. The idea is to create a financial hedge, such that lower interest payments occur when the economy is in a recession, and vice versa. More generally, the debt could be structured so that it provides a hedge against the balance sheet value of the government. (New Zealand has recently altered its liability profile to offset the duration of sovereign assets.)

With predominantly real shocks, the correlation between output and bonds is such that when domestic output decreases, inflation increases, leading to lower real interest payments. Goverrıments, therefore, should issue long-term domestic debt when real shocks are important. When monetary shocks dominate, the hedging function disappears.

Along the same lines, foreign debt may be correlated with domestic output and thus also serves as a hedge. Again, this is only useful when foreign monetary shocks are not too important. Empirically, this may explain why a large share of foreign debt is denominated in deutsche marks, Swiss francs, and Japanese yen-all currencies that have stable monetary policies. Bohn (1990) also argues that foreign currency (mainly dollar) borrowing by less developed countries (LDCs) in the 1970s served as a hedge against real oil price increases, which led to decreased output and higher inflation in the 1970s. Unfortunately, this strategy unraveled as U.S. monetary policy drastically changed in the 1980s. Ultimately, the issue is one of size and stability of correlations with domestic output.

\section{Incentive Problem}

The second class of distortions consists of time inconsistency of government policies. Governments have incentives to create infla-

\section{(C)International Monetary Fund. Not for Redistribution}


tion as a means to depreciate the value of their debt. This incentive, however, is recognized by the private sector and as a result may be priced as an additional risk factor of government debt.

This incentives problem can be addressed by a series of measures that are designed to "tie" the government's hands: (1) issuing floating rate debt, which is immune to unexpected inflation; (2) issuing foreign currency debt, which is not affected by domestic inflation; (3) credibly pegging the exchange rate: and (4) establishing an independent central bank.

One should note that the only solution that addresses the first two types of distortions is foreign currency-denominated debt.

\section{Liquidity Crisis}

The third class of distortions consists of what are called "multiple equilibria." Michael Dooley argues that "self-fulfilling" expectations can create a crisis when repayment maturities are grouped together and the government appears to be unable to make good on all its promises. By all simultaneously rushing to the exit door, market participants create a crisis. To avoid this situation, governments should avoid short-term debt, presumably because it has to be rolled over too often.

No doubt this line of reasoning has been heavily influenced by the recent problem with tesobonos, when it became clear that the Mexican government did not have sufficient foreign currency reserves to roll over its dollar-denominated short-term debt.

\section{Default Risk}

The fourth class of distortions consists of the cost of default. Assuming that the cost of default is high, multiple classes of creditors raise the probability that one class of "hostile" creditors will force default. Michael Dooley argues that this should lead governnent to select a small number of creditor classes, leading to the optimal choice of domestic long-term debt.

\section{Summary}

In an attempt to clarify the issues, Table 3.1 presents the recommendations by type of distortion. The different models are some- 
what incompatible. For instance, if one believes the hedging argument, then long-term debt (domestic or foreign, if usef ul) should be preferred. If the incentives argument is an issue, then long-term debt should be avoided. The crisis and default arguments lead to the use of long-term debt, preferably domestic.

Table 3.1. Optimal Choice of Debt: Summary of Implications by Theories

\begin{tabular}{lll}
\hline & Theory & \\
Maturity: & Short-term & Long-term \\
Currency: & & \\
Domestic & -Hedging \\
& -Incentives & -liquidity \\
& -Default \\
Foreign & -Hedging (?) \\
& -Incentives & -lncentives \\
& -Liquidity \\
& -Default (?) \\
\hline
\end{tabular}

The main conclusion, in my view, is that the appropriate strategy depends on the particular situation a country is in, and on the relative weight one attaches to the different types of distortions. Michael Dooley argues that the costs of default are so huge so as to swamp any other argument; self-fulfilling expectations are also, in his view, a major problem, with the potential of causing liquidity crises. Hence, the preferred choice is domestic long-term debt.

\section{Additional Comments}

Let me now present a different approach to these two points.

\section{"Self-Fulfilling" Expectations}

The Mexico crisis was clearly triggered by the tesobonos sinuation. Whether the expectations of the private sector were irrational is another matter. In fact, it could be argued that the crisis was inevitable because of unsustainable economic policies. The crisis occurred because the peso was substantially overvalued. Figure 3.1, for example, plots the nominal exchange rate in comparison with the purchasing power parity value, using both CPI and WPI measures. Using the latest devaluation as a base period, it appears that the 
Figure 3.1. Purchasing Power Parity Rate: Mexican Peso/U.S. Dollar (Peses/L!S dollars)

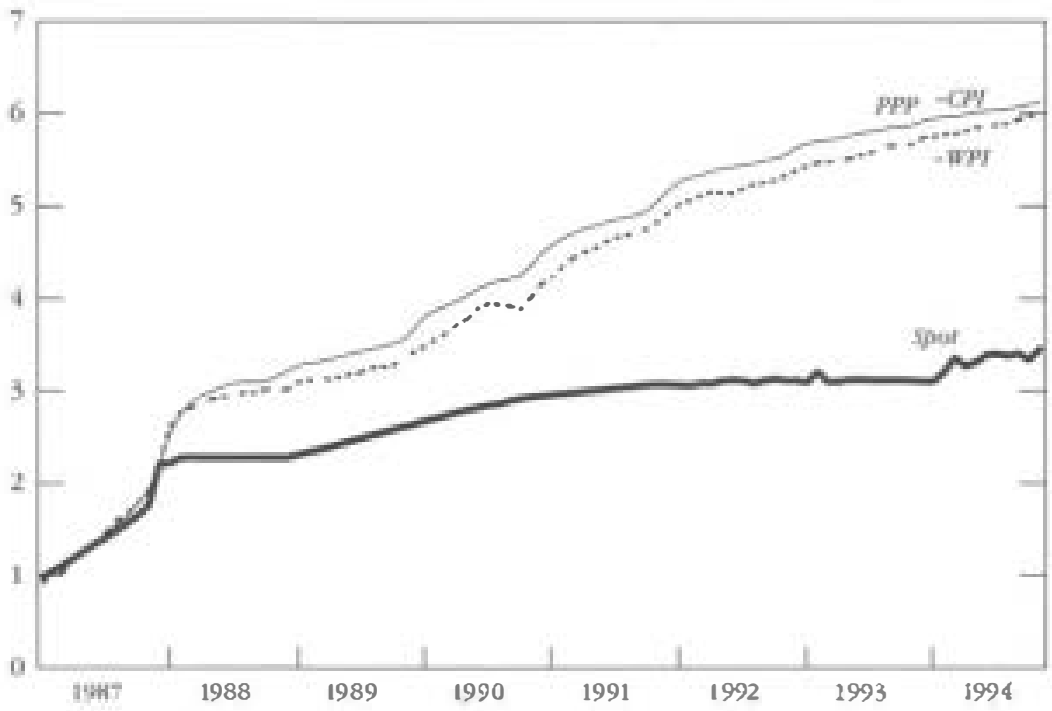

Source: IMF, International Financial Statisties.

equilibrium value of the peso should have been about 6 pesos to the dollar, which is where the exchange rate moved after the devaluation. If the devaluation was rational, it cannot be viewed as being "caused" by the tesobonos problem. To summarize, once sound and transparent government policies are in place, it is unlikely in my view there will be an irrational liquidity crisis.

\section{Default}

In fact, let us check whether short-term debt has been historically associated with default. Frankel and Rose (1996) provide an interesting analysis of a large-scale sample of 117 currency crashes. This probit analysis relates the probability of a crash with a number of economic factors. The main results are displayed in Table 3.2. The first panel shows that internal factors were a major leading indicator of currency crashes. The probability increases with increasing government deficit, increasing domestic credit, and decreasing growth rates. External factors were also important, with the proba- 
Table 3.2. Factors Affecting Currency Crashes

Probit Analysis of Probability of a Crash

Factor

Probit Coefficient

(istatistic)

\begin{tabular}{|c|c|c|}
\hline Internal & $\begin{array}{l}\text { Government deficit } \\
\text { Domestic credit } \\
\text { Growth rate }\end{array}$ & $\begin{array}{l}0.27^{*} \\
0.13^{* \bullet} \\
-38^{\circ *}\end{array}$ \\
\hline External & $\begin{array}{l}\text { Reserve/impoits } \\
\text { Overvaluation } \\
\text { Foreign interest rate }\end{array}$ & $\begin{array}{l}-0.01^{* *} \\
0.05 \\
1.27^{\circ *}\end{array}$ \\
\hline Debt stuucture & $\begin{array}{l}\text { FDV/debt } \\
\text { Debt'GNP } \\
\text { Concessional } \\
\text { Short-term }\end{array}$ & $\begin{array}{c}-0.33^{\circ 0} \\
0.03 \\
-0.10 \\
0.04\end{array}$ \\
\hline
\end{tabular}

Source: Frankel and Rose (1996).

bility increasing with decreasing reserves, increasing overvaluation, and increasing foreign interest rates. All of these effects are expected.

Quite interesting also is the effect of debt structure. The probability of crash increases with decreasing foreign direct investment, increasing debt levels, and decreasing concessional debt. But the variable that accounts for the propertion of short-term versus longterm debt is insignificant, indicating that the maturity of external debt has historically had little effect on the probability of currency crises. Empirically, therefore, there is little evidence that short-term debt is dangerous.

Another issue is the cost of default, which is not obvious for sovereign borrowers. Here, a link should be made with corporate finance. Once the Modigliani-Miller assumptions are relaxed, traditional corporate finance theory relies on bankruptcy costs to rationalize an optimal capital structure, which is derived from increasing debt costs from higher debv/equity ratios. Empirical researchers, however, have been at a loss to observe significant bankruptcy costs. Direct costs are typically on the order of 1-2 percent of the value of the firm, which is embarrassingly too low to explain an optimal capital structure. Researchers have then turned to "indirect costs" as an explanation for high bankruptcy costs. These indirect costs stem from disruptions to normal operations and to lost customers, for instance. 
The point is that we have little evidence on the cost of sovereign defaults. Direct costs may be similar to those for corporate defaults, but it is not clear what indirect costs are for countries. The cost of default should also be sharply distinguished from the costs of policies that led to default. The latter costs are probably large, and would have to be incurred whether or not the country defaults on its debt.

\section{Conclusions}

By now, the reader is probably thoroughly confused. This confusion, however, reflects the conflicting advice from various theoretical models of asset and liability management. Different models lead to different conclusions. The question is: How does one choose between models?

In my view, we currently have too little information to provide a useful answer to this important question. More empirical work needs to be done on the hedging properties of long-term bonds and on the cost of default, for instance.

Overall, the answer provided by Michael Dooley in his excellent survey cannot be considered as totally satisfactory. The advice is to borrow exclusively in long-term domestic currency because the cost of default is so high. But then, if the cost of default is so important, why is the recommended policy for developing countries identical to the actual practice of industrial countries, for which the probability of default is negligible? We need more information to converge toward an acceptable answer.

\section{References}

Bohn, Henning, 1990, "Positive Theory of Foreign Currency Debt," Journal of International Economics, Vol. 29, pp. 273-92.

Frankel, Jeffrey, and Andrew Rose, 1996. "Currency Crashes in Emerging Markets: An Empirical Treatment," Intemational Finance Discussion Paper 534, Board of Governors of the Federal Reserve System (January). 


\section{4}

\section{Foreign Currency Liabilities in Debt Management}

\section{Patrick de Fontenay and Philippe Jorion}

For governments (or firms) that borrow, as most do, whether to 1 issue foreign currency denominated debt, how much, and in which currencies seem to be separate decisions, subject to different considerations. Indeed, this is how many countries have approached foreign borrowing. For example, a central bank may decide it needs to replenish its stock of foreign exchange reserves and how much it should borrow abroad. The choice of currency or currencies in which to borrow is then decided separately.

Historically, for many developing countries, the choice of currencies in which to denominate their foreign debt was imposed by the lenders, and in the absence of easy access to the swap market that choice could not be changed. For a second category of countries, the necessity of borrowing abroad was imposed by the balance of payments or official reserve situation, or by the narrowness of the domestic market for government debt, either in terms of volume, liquidity, or choice of maturities. Governments were also able to borrow on better terms than public enterprises and private firms to which they would lend the proceeds of their foreign borrowing. For those countries, the choice of currencies is an important decision to be taken as part of their external debt management. Finally, there is a third category of countries, which includes most industrial countries and several developing countries. In those countries, governments are not compelled to issue debt denominated in foreign currencies, and some choose not to. Of course, from a balance of payments standpoint, sales to nonresidents of government bonds denominated in local currency represent foreign borrowing. 
The first part of this paper discusses the currency composition of foreign debt, largely from the standpoint of the countries in the second category. The second part discusses the role of foreign currency debt in sovereign liability management and reviews the different approaches to this issue. The third part is a numerical application of modem portfolio theory to a country case.

\section{Currency Composition of Foreign Debt}

For countries whose governments (or central banks) need to borrow abroad, the traditional advice to match foreign assets and liabilities was often impractical. This was often because foreign assets were too small or because the management of foreign assets (that is, official reserves) and that of foreign debt was done by different entities and in accordance with different sets of principles and guidelines. Another standard piece of advice was to borrow in the currency or currencies of the main trading partner(s). Intuitively, this seems to make sense as debt payments would be in the same currencies as export receipts, and cash flows would match. However, this may not be the best advice.

As an example, Argentina, whose currency is pegged to the U.S. dollar, would seem a perfect candidate for denominating its foreign debt in dollars. However, if the dollar appreciates, Argentine exports both to the United States and to third markets will lose their competitiveness relative to nondollar countries. Export receipts are likely to decline and the debt service-to-exports ratio is likely to rise. In this case, some borrowing in currencies other than the U.S. dollar would have stabilized the debt-service ratio.

For primary producers, the currency in which the main exports is denominated may be different from that of their main trade partner. Indonesia, for example, sells oil priced in U.S. dollars to Japan. In 1986 and 1987, it was hit by the depreciation of the dollar and the fall in oil prices, while a substantial share of its foreign debt was in Japanese yen and European currencies. As a result, the debt-service ratio rose from about 20 percent in 1984 to 28 percent in 1987 . Borrowing in the currency in which the main export is priced is not necessarily optimal, however, as commodity price movements do not always offset exchange rate changes. In 1993, for example, the appreciation of the U.S. dollar was more than offset by the decline 
in the price of oil, and oil exporters would have benefited from having borrowed in currencies other than the U.S. dollar.

A more sophisticated approach consists in deterınining the currency composition of external debt so as to minimize the variance of a country's terms of trade or debt-service ratio as a result of exchange rate fluctuations. By borrowing in foreign currencies, a country can hedge against changes in net foreign exchange receipts expressed in the national currency if those changes are positively correlated with movements in the exchange rates of those currencies. Thus, if the appreciation of a country's trade partner's currency is associated with an improvement in its trade balance or terms of trade, the country could stabilize its debt-senvice ratio, if it borrowed in that currency. ${ }^{1}$ The rise in the debt-service obligations resulting from the appreciation would be offset by the improvement in the trade balance (both expressed in domestic currency). In the simplest form of this model, the currency composition of the external liabilities depends only on the covariances among exchange rates and the covariances between exchange rates and net foreign exchange receipts. Borrowing costs (and the covariances between these costs) can, however, be integrated into the model-as in Claessens (1992). The practical limitations of the approach result from the fact that the relationship between exchange rate changes (or borrowing costs) and terms of trade changes are for many countries weak or unstable.

One still hears occasionally the view that currency selection is irrelevant, as domestic inflation rates are reflected in local interest rates and exchange rates adjust to offset the interest rate differential for (unhedged) foreign investors or borrowers-that is, the high interest currency is expected to depreciate relative to the low interest currency (this expectation being reflected in forward exchange rates). The experience has been otherwise, however, as for lengthy periods since the collapse of the Bretton Woods exchange rate regime, forward exchange rates have overestimated changes in the spot rate and actual exchange rate changes have not fully offset the interest rate differentials. Indeed, a popular strategy for many debtor countries has been to borrow in those countries where lending rates were the lowest. Sometimes, the main motivation has been to reduce

'See Claessens (1988) and (1992); and Kroner and Claessens (1989) and (1991). So-called "natural hedges," such as royalty receipts in a specific currency, can easily be integrated into the model. 
the short-term impact of the debt-service payments on the government budget. Even if the benefit of the favorable interest differential in the low-cost countries is subsequently offset by the cost of currency appreciation, the recognition of the capital loss can be postponed and even entered "above the line" in the budgetary accounts. More frequently, such a currency selection strategy has reflected its success. It is a risky strategy, however, as its popularity among investors and borrowers in selecting the currencies participating in the European Monetary System (EMS) and the heavy losses incurred when the EMS broke down in 1992 readily demonstrate.

The case for currency diversification of external debt remains strong, both on theoretical and practical grounds, as it is for international investing. For many developing countries, its main benefit is to reduce the risks associated with the impact of interest rate and exchange rate changes or their ability to meet their external debt obligations. In other words, the cost minimization aspect of diversification may be less important than the prevention of a debt crisis. Ideally, the diversification process should take account of the main factors that affect a country's ability to service its debt, including any "natural hedges" that may exist, with a view to minimizing the variance of the debt-service ratio.

\section{Role of Foreign Currency Debt ${ }^{2}$}

By contrast with the group of countries that is forced to incur debt denominated in foreign currencies, there is another group for which foreign currency debt is an option but not a necessity. With the dismantlement of capital controls and the global integration of financial markets, it is possible for countries in that group to tap foreign investors and lenders by issuing debt instruments denominated in the national currency. They have a foreign debt but it is not expressed in terms of foreign currencies. Governments in the United States, Germany, and Japan only issue debt denominated in local currency (except for the so-called "Carter bonds"). Recently, New Zealand has stopped borrowing in foreign currencies. Australia does not issue public debt denominated in foreign currencies but swaps part of its public debt into such debt. The private sector is of course free to borrow in any form and denominations it chooses.

${ }^{2}$ This section is based in part on de Fontenay, Miesi-Ferretti, and Pill (1995). 
Why do some countries' governments choose to have some of their debt denominated in foreign currencies? Some of the main considerations are the following.

\section{Size of Market and Availability of a Wider Range of Debt Instruments and Maturities}

This has been a major factor in the past, but much less relevant today with global financial integration.

\section{Macroeconomic Hedging}

In theory, the choice between domestic and foreign debt could be made on the basis of which one provides the better hedge against macroeconomic risk, such as output fluctuations or terms of trade shocks, and resuits in smoother consumption flows. If terms of trade losses are associated with a depreciation of the domestic currency and a rise in the price level, the decline in the real value of the debt in local currency held by foreigners will offset some of the income losses caused by the fall in the terms of trade. There would be no offset in the case of foreign currency debt. But such an association is uncertain and domestic interest rates could rise and offset the effect of the devaluation.

Other shocks will have different implications for the economy depending on the denomination of the debt. Real interest rate shocks are more easily diversified away for foreign currency debt than for domestic debt. Foreign borrowing can provide a hedge against inflation in the creditor country or a rise in import prices, if the debtor country cannet insulate itself completely through the exchange rate, and its debt is at a fixed interest rate.

Foreign currency debt can make a countiy more vulnerable to capital outflows-as the role of tesobonos in the 1994-95 Mexican crisis amply demonstrates. The degree of vulnerability depends, however, on other factors such as the current account position (which is related to private sector decisions) and the responsiveness of capital flows to changes in domestic interest rates, as well as the maturity structure of the debt. In a crisis, a government can reduce the value of its domestic debt through inflation; for foreign debt, default is the ultimate escape. 
From a more narrow standpoint, the choice between domestic and foreign currency debt could be made dependent on which one minimizes the variability of the budget balance. If budgetary outlays on account of foreign currency-denominated public debt are negatively correlated with other government spending or positively correlated with government revenue, debt in foreign currencies would stabilize the budget balance and avoid the negative impact on the economy of a larger deficit or of higher taxes. For the group of countries under consideration in this section, this may be much less important than for the other countries. Their economies are more resilient and their income levels high enough to sustain some fluctuations in real income. Nevertheless, those countries in the group that are heavily dependent on energy or raw material exports, like Australia and Canada, may welcome greater stability in the current account if it could be achieved through appropriate selection of currencies for foreign borrowing. If there were, for example, a robust tendency for the prices (in U.S. dollars) of their primary exports to fall when the dollar appreciates, but by more than the dollar strengthens, then borrowing in nondollar currencies would stabilize the current account of the balance of payments - in contrast with borrowing in dollars only. ${ }^{3}$ The considerations are the same as those discussed for currency composition of external debt in the first part of the paper.

\section{Policy Signal}

The issuance of public debt denominated in a foreign currency can provide a signal that the authorities will not attempt to reduce the value of debt through inflation. It gives credibility to the government's anti-inflation program and may reduce the cost of borrowing if domestic interest rates incorporate an "inflation risk premium," which the authorities do not regard as justified in view of their deternination to reduce inflation. The same result could be

If the local currency depreciates versus the dollar to the same extent as the other nondollar currencies, the value (in domestic currency) of debt-service payments in those currencies remains unchanged, while it increases for the dollardenoninated debt. The increase would accentuate the worsening of the current account, resulting from the deterioration in the terms of trade. 
achieved, however, by issuing inllation-indexed bonds denominated in local currency.

Indexed bonds do not carry an exchange rate risk, and given that government revenue is positively correlated with infation, the issuer is also protected anainst an inflationaly stock. By "selling protection" agalnst inflation to investors, the authorities can expect (o) lower the cost of their borrowing. They also proricle investors $w$ ith a new financial instrument, which may have a favorable effect on the satings rate But from the standpoint of liabilty management. indexed bonds are not a sul sutitute for foreign currency debt, as they provide: limited diversificaltion.

\section{Cost and Risk Minimization}

For countries in this greup. this is the most reletint consideraltim Like a corporate treasurer, the agency resiponsilske for pulslic (lest management will seek to reduce borrowing costs without laking unduce rtsk. Despite its well-knosun limilations, the mean vartianca: approach is a useful starting point According to this approach, the stare of foreign delut in total shels and the currency composition sit foreign clelst are determined simultaneousily

The optimization procestis ulises as inputs the cost of botrow ing in the various: findncial markets (including the domestic market) and the covariance; betw een the various interest rates. exchange matten. and the whole dety portolio (see Jorion. 1994) Currency itsum caln be based on historical dialla or assiunzed to be zero. The prexess produces an etficient frontier of optimal risk-return combinations of interes atales and currencies. It is important 10 note (hat the inclusion of currencies, in the portlolios does, not depend on thesr has ing positive cexpecied returns

The selection of a point on the frontier can ba made on the bass.

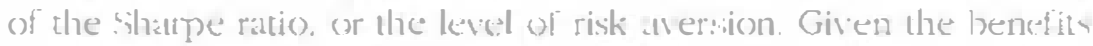
of international atsiset diversification, ${ }^{5}$ th is not clear why some countries eschew foreign currency borrowing. which is the Mip wide of international investing, als, the same arguments for investing inter mattionally atproly to borrowing internationally: Bossible reasons include

'Ses: for example kritura!n (1093)

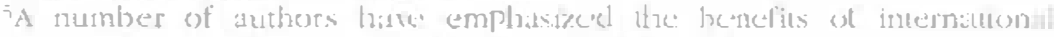
diversit ication see for eximple. () die's and solnk (1(x)3) 
extreme risk aversion, or the view that foreign lenders do not assess correctly the country's economic prospects and insist on a "risk premium," which the authorities regard as unjustified. The largest industrial countries may want to encourage the use of their currencies and the development of their own financial markets by issuing public debt only on the domestic market. The size and the efficiency of their domestic markets, relative to the rest of the world, also limit diversification benefits.

\section{The Case of Australia}

\section{Cost and Risk of Borrowing in Australian Dollars}

As an illustration, consider the case of Australia. Table 4.1 presents data on the cost and risk of borrowing in Australian dollar bonds as well as in five other major markets from 1978 to 1995. These performance numbers are taken from the Salomon Brothers World Bond Indices, which cover all bonds with remaining maturities above five years. The value of each bond index is marked to market each month, includes capital appreciation and coupon payment, and is translated into Australian dollars. These data can be given two interpretations: the usual one is that of investment performance numbers for an investor; the other is that of cost of capital numbers from the viewpoint of sovereign borrowers.

The return, or cost, on an unhedged bond incorporates movements in the local currency price $P *$ and in the spot rate price of the foreign currency $S$. Considering two time periods, 0 and 1 , this return is:

$$
R^{u}=\left(P^{*}{ }_{1} S_{1}-P^{*}{ }_{0} S_{0}\right) / P^{*}{ }_{0} S_{0} .
$$

The top part of the table shows that, over this period, costs would have varied between 11.42 percent annually (for Swiss francsdenominated bonds) to 16.16 percent (for yen-denominated bonds). Borrowing in Australian dollars would not have been too expensive, with an all-in nominal cost of 11.87 percent. The reason for this low cost is that, even though Australia had high interest rates over the period, the Australian dollar slid from a U.S. dollar value of 1.14 to 0.75 from 1978 to 1995 . This depreciation more than offset interest rate differentials and created a relatively low total borrowing cost. 
Table 4.1. Cost and Risk: Major Bond Markets in Australian Dollars (Annual returns in percent, 1978-95)

$\begin{array}{lcrrrrr} & \begin{array}{c}\text { Austsalian } \\ \text { Dollar }\end{array} & \begin{array}{c}\text { U.S. } \\ \text { Dollar }\end{array} & \begin{array}{c}\text { Deutsche } \\ \text { Mark }\end{array} & \begin{array}{c}\text { Japanese } \\ \text { Yen }\end{array} & \begin{array}{c}\text { Pound } \\ \text { Sterting }\end{array} & \begin{array}{c}\text { Swiss } \\ \text { Franc }\end{array} \\ \begin{array}{lcrrrr}\text { Unhedged bonds } \\ \quad \text { Cost }\end{array} & 11.87 & 13.28 & 13.11 & 16.16 & 14.13 & 11.42 \\ \quad \begin{array}{l}\text { Risk } \\ \text { Hedged bonds }\end{array} & 8.98 & 13.85 & 16.48 & 17.59 & 17.63 & 16.33 \\ \quad \begin{array}{l}\text { Cost } \\ \quad \text { Risk }\end{array} & & 13.26 & 12.46 & 14.29 & 12.48 & 11.54 \\ \begin{array}{l}\text { Cursencies (long) } \\ \quad \text { Cost }\end{array} & & 9.92 & 5.74 & 6.60 & 982 & 4.50 \\ \quad \text { Risk } & & 0.02 & 0.65 & 1.87 & 1.65 & -0.12 \\ & & 9.64 & 14.40 & 14.45 & 13.33 & 15.46\end{array}$

Source: Salomon Brothers World Bond Indices.

In terms of risk, the month-to-month volatility of Australian dollar bonds was about 9 percent. Foreign currency-denominated bonds, however, exhibited much greater risk, with volatility varying from 13.85 percent (for U.S. dollar bonds) to 17.63 percent (for British pound bonds). Perhaps this explains why some countries prefer not to issue foreign currency-denominated bonds, as they appear more risky.

\section{Separating the Currency and Bond Market Decisions}

Positions in foreign bonds involve the same exposure to both the foreign bond market and to the foreign currency. But there is no need to do so. There is no reason to assume that the same position will create the lowest borrowing cost. Long-term yields in one currency, for example, could be viewed as relatively low but the currency itself could be expected to appreciate over the sholt term. One strategy to take advantage of these views would be to borrow long term in this market while buying a short-term forward cover. In other words, this is a short position in a currency-hedged bond. More generally, the two components can be separated through the use of derivative contracts such as fonvards, futures, or swaps. ${ }^{6}$

'If the instrument is a long-term currency swap that exactly matches the cash flows of the foreign currency bond, the bond effectively becomes a domestic currency bond, and there is no residual exposure to foreign interest rates. Such currency swaps do not represent views on foreign interest rates or currencies, but rather take advamage of market conditions to lower capital costs. In the case of short-term swaps, which are effectively forward contracts, we know from covered interest rate parity that differences in capital costs should be small. 
The cost of a hedged bond is composed of that on an unhedged bond plus the payoff on a long forward contract. Defining the initial forward rate as $F_{0}$, the return can be defined as:

$$
R^{b}=\left(P_{1}^{*} S_{1}-P_{0}^{*} S_{0}\right) / P_{0} S_{0}-\left(S_{1}-F_{0}\right) / S_{0}=R^{u}-R^{\prime}
$$

As the amount hedged is the same as the exposure to the foreign market, this can be called "unitary hedging." The second set of rows in Table 4.1 displays the cost and risk of currency-hedged bonds. These represent the pure "bond" component of foreign bonds. While differences in returns are relatively small, the risk of foreign currency bonds is dramatically decreased. For Swiss franc bonds, for instance, the volatility drops from 16.33 percent to only 4.50 percent. This remaining volatility is that of the Swiss bond market, which in fact turns out to be much more stable than the Australian bond market. Thus, if the goal is to provide a stable long-term source of capital. the local bond market may not be the best choice. More generally, however, there is no reason to believe that unitary hedging is optimal, especially in the context of a large portfolio.

Table 4.1 also shows that most of the risk of foreign bonds is actually due to movements in exchange rates. The third set of numbers in the table display's the volatility of returns on forward contracts, which represent short-term movements in exchange rates. The table shows that this risk is quite substantial. For the Swiss franc, for instance, the $\mathrm{A} \$ / \mathrm{SwF}$ exchange rate has a volatility of 15.46 percent, which is nearly as large as that of the Swiss bond itself.

One of the basic tenets of portfolio theory is that a diversified portfolio will generally have lower risk than individual assets, provided correlations are less than unity. Correlations are presented in Table 4.2. The table shows correlations of hedged bonds with other hedged bonds and with currencies, as well as correlations between currencies. Correlations between hedged bonds are generally low. The lowest number is 0.13 , between Australia and Switzerland. The highest is 0.59 , between Germany and Switzerland. As a result, we would expect that portfolio risk could be substantially reduced by spreading risk among many hedged bond markets.

Table 4.2 also shows correlations between hedged bonds and currencies, and within currencies. The former correlations help to determine the risk of unhedged bonds. Define $V\left(R^{u}\right)$ as the variance of an unhedged bond. Going back to the hedged return plus currency return decomposition in (2), this variance is also: 


$$
V\left(R^{i b}\right)=V\left(R^{b}\right)+V\left(R^{s}\right)+2 \operatorname{Cov}\left(R^{b}, R^{s}\right) .
$$

For instance, Table 4.2 shows that the correlation between Swiss franc hedged returns and the Swiss currency is 0.05 . The components of unhedged Swiss franc returns are shown in Table 4.3.

The variance components translate into a total risk of unhedged bonds of 16.3 percent, precisely the number in Table 4.1. These correlations are small, but slightly positive, implying that, for instance, an appreciation in the Swiss franc is associated with decreasing Swiss franc interest rates. This positive correlation magnifies the risk from foreign currency borrowing. Thus, unit hedges may not be optimal.

\section{Table 4.2. Correlation Coefficient}

Correlations of hedged bonds with:

$\begin{array}{cccccc}\text { Australian } & \text { U.S. } & \text { Deutsche } & \text { Japanese } & \text { Pound } & \text { Swiss } \\ \text { Dollar } & \text { Dollar } & \text { Mark } & \text { Yen } & \text { Sterling } & \text { Frane }\end{array}$

Hedged bonds

Australian dollar $\quad 1.00$

U.S. dollar 0.32

Deutsche mark $\quad 0.21 \quad 0.51$

$\begin{array}{lll}\text { Japanese yen } & 0.15 & 0.39\end{array}$

Pound sterling $\quad 0.15$

Swiss franc $\quad 0.13$

0.41

$0.13 \quad 0.34$

$0.55 \quad 1.00$

Currencies

U.S. dollar

Deutsche mark

$\begin{array}{ll}-0.24 & 0.00\end{array}$

$-0.13 \quad 0.19$

0.59

0.39

0.42

Japanese yen

0.15

Pound sterling

$-0.11$

$-0.06$

0.18

$-0.04$

0.41

1.00

Swiss franc

0.15

0.21

0.13

$\begin{array}{ll}-0.04 & -0.02\end{array}$

$-0.03$

$0.21 \quad 0.00$

0.06

0.09

0.29

0.10

0.10

0.19

0.14

0.14

0.01

$-0.08$

0.20

0.00

0.05

Correlations of currencies with:

Currencies

U.S. dollar

Deutsche mark

Japanese yen

Pound sterling

Swiss franc

1.00

0.51

0.48

0.78

0.46

0.71

1.00

0.47

0.61

0.93

1.00

0.72

0.75

1.00

Correlations of unhedged bonds with:

Unhedged bonds

Australian dollar $\quad 1.00$

U.S. dollar $\quad 0.06$

Deutsche mark $\quad-0.04$

1.00

$-0.04 \quad 0.54$

Japanese yen $\quad-0.04$

Pound sterling $\quad 0.00$

0.46

0.48

Swiss franc

$-0.04$

0.50

1.00

$0.69 \quad 1.00$

$\begin{array}{lll}0.63 & 0.55 & 1.00\end{array}$

$\begin{array}{lll}0.91 & 0.70 & 0.60\end{array}$

1.00 
Table 4.3. Components of Unhedged Swiss Franc Returns

\begin{tabular}{lrr} 
& \multicolumn{2}{c}{ Variance Components } \\
\hline Risk of hedged Swiss franc bonds & 4.50 & 20.3 \\
Risk of Australian dollar/Swiss franc & 15.46 & 239.0 \\
Correlation & 0.05 & 7.0 \\
Total & & 266.3 \\
\hline
\end{tabular}

\section{Optimal Portfolios}

More generally, the currency position should take into account all interactions between currencies and interest rates. All of this information about costs, risk, and correlations can be translated into portfolio positions using modern portfolio theory. Figure 4.1 presents the traditional "efficient set," which plots the locus of portfolios that minimize risk for given cost leveis. In the usual application of mean-variance analysis, the goal is to move up and to the left, which implies selecting a point on the upward-sloping portion of the curve. For borrowers, the goal is to minimize a function of the portfolio cost and risk, which implies selecting a point on the lower part of the efficient set.

From Table 4.1, we know that the bond market with the lowest cost is Switzerland. Therefore, the efficient set starts at the bottom with the Swiss market. As the Australian market had similar cost, but lower risk, the efficient set is relatively flat on its bottom part, which means that there is little room for cost reduction relative to borrowing in Australian dollars. The exact allocation depends on the risk aversion. For simplicity, assume that the function to be minimized involves the expected return $E(R)$ and the variance $V(R)$ as in:

$$
E U=E(R)+g V(R)
$$

The bortower trade-off between low cost and low risk is expressed by the parameter $g$, which we assumed arbitrarily to be $3 .{ }^{7}$

The top part of Table 4.4 shows the optimal allocation with unhedged bonds only. The total cost amounts to 11.74, a gain of 13 basis points relative to borrowing in Australia only, with a risk level

'This number was selected from the typical risk aversion of equity investors. U.S. stocks have returned about 8 percent a year with a risk of 16 percent. This implies a risk aversion of about $0.08 /\left(0.16^{*} 0.16\right)=3$. 
Figure 4.1. Optimal Portfolio Choice: Unhedged Bonds Cost (Percent per year)

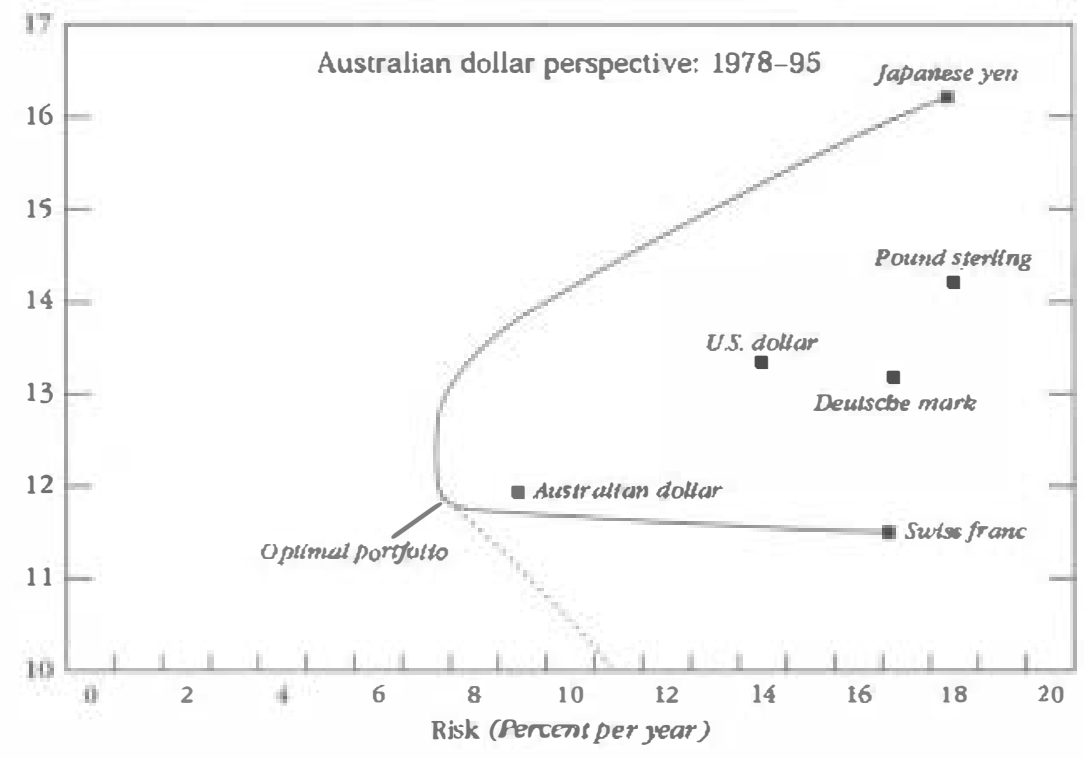

Source: Author's calculations.

Table 4.4. Optimal Allocations

\begin{tabular}{|c|c|c|c|c|c|c|}
\hline & $\begin{array}{c}\text { Australian } \\
\text { Dollar }\end{array}$ & $\begin{array}{c}\text { U.S. } \\
\text { Dollar }\end{array}$ & $\begin{array}{c}\text { Deutsche } \\
\text { Mark }\end{array}$ & $\begin{array}{c}\text { Japanese } \\
\text { Yen }\end{array}$ & $\begin{array}{l}\text { Pound } \\
\text { Sterling }\end{array}$ & $\begin{array}{l}\text { Siviss } \\
\text { Fianc }\end{array}$ \\
\hline & \multicolumn{6}{|c|}{ Optimal allocations: unhedged bonds only } \\
\hline \multicolumn{7}{|c|}{ S } \\
\hline \multicolumn{7}{|l|}{ Risk: 7.74} \\
\hline \multicolumn{7}{|l|}{ Net position } \\
\hline Bonds & $73.2 \%$ & $0 \%$ & $0 \%$ & $0 \%$ & $0 \%$ & $26.8 \%$ \\
\hline Currencies & $73.2 \%$ & $0 \%$ & $0 \%$ & $0 \%$ & $0 \%$ & $26.8 \%$ \\
\hline \multicolumn{7}{|c|}{ Optimal allocations: bonds and currencies } \\
\hline Cast: 11.57 & & & & & & \\
\hline Risk: $\quad 4.27$ & & & & & & \\
\hline \multicolumn{7}{|l|}{ Net position } \\
\hline Bonds & $10.0 \%$ & $0 \%$ & $0 \%$ & $0 \%$ & $0 \%$ & $90.0 \%$ \\
\hline Currencies & $99.8 \%$ & $0 \%$ & $0 \%$ & $0 \%$ & $0 \%$ & $0.2 \%$ \\
\hline
\end{tabular}

\section{(C) International Monetary Fund. Not for Redistribution}


of 7.74 , which is a gain of 125 basis points. ${ }^{8}$ The position has perforce the same allocation on bonds and currencies, with 73.2 percent on the Australian dollar and 26.8 percent on the Swiss franc.

Next, Figure 4.2 presents the efficient frontier with unhedged and hedged bonds. This is equivalent to considering a menu of assets consisting of bonds and currencies, with only positive positions on bonds and limits on currency positions. The new line moves sharply to the left relative to that in Figure 4.1. The optimal portfolio is detailed in the bottom part of Table 4.4. Relative to the first allocation, costs are further reduced from 11.74 percent to 11.57 percent, and risk is sharply lower, from 7.74 percent to 4.27 percent. The optimal allocation between bonds and currencies is now decoupled, with 10 percent in Australian dollar bonds, 90 percent in Swiss franc bonds, but essentially 100 percent in Australian dollars. For the risk aversion we selected, the portfolio achieves diversification across bond markets without incurring foreign currency risk.?

\section{Generalization}

This example was presented for the purpose of demonstrating the usefulness of the mean-variance framework. More generally, the optimization can be based on the Treasurer's exchange rate and interest rate forecasts. If necessary, constraints can be added. A major advantage of this framework is that it generates portfolio allocations that are consistent with the objective function, market projections, risk, and correlations.

This approach is also consistent with recent developments in risk management based on the concept of value-at-risk (VAR). VAR addresses the question, "What is the worst possible loss over a monthly horizon at the 95 percent level of confidence?" Computing the portfolio VAR is useful for a number of purposes, including effectively communicating the downside risk of the portfolio to a nontechnical audience, understanding the components of portfolio risk, and establishing a systematic procedure to control risk and plan for

\footnotetext{
${ }^{8}$ Because this is an ex post optimization, the efficient set must dominate any single investment. Therefore, there may be a bias resulting from optimization, which has been noted by Michaud (1989).

9 Similar results are obtained when considering only the more recent 1986-95 period.
} 
Figure 4.2. Optimal Portfolio Choice: Bonds and Hedges Cost (Pencent per year)

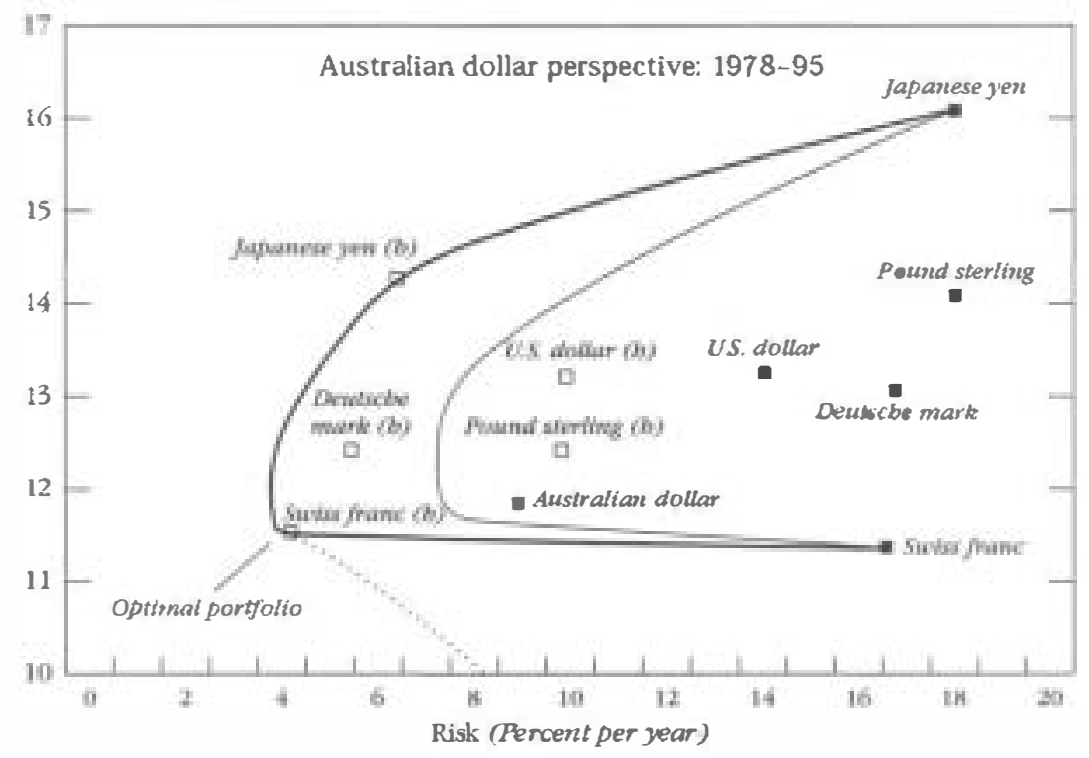

Source: Author's calculations.

worst-case scenarios. With the assumption of jointly normal distributions underlying the mean-variance approach, VAR is simply related to the overall portfolio standard deviation.

The framework presented here can be easily generalized. For instance, our analysis is based on monthly data. If the reporting interval, over which the portfolio is marked to market, is different, this can be adjusted easily. Also, we only considered prices in the domestic currency, in nominal Australian dollars. If the goal is macroeconomic hedging, the numéraire can be adjusted easily. For instance, assume that the Treasurer wishes to stabilize the volatility of the portfolio value relative to that of output fluctuations. As explained earlier, hedging is beneficial if states of the world where the economy grows strongly are associated with situations where borrowing costs are higher, because these are precisely the situations where the country can afford greater costs. Conversely, when output is low, the goal is to have lower debt costs. The exercise can then be repeated by measuring costs relative to the desired index. 
Table 4.5. Cost and Risk of Various Strategies (Annical returns in Atustralian dollars, 1978-95)

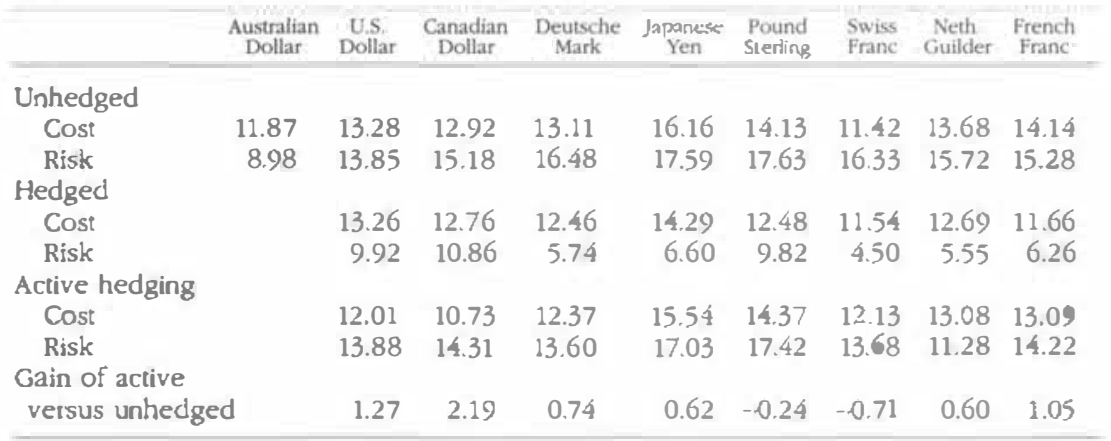

Finally, this framework can be adjusted to implement market views. By now, there is an abundant literature on "anomalies" in the foreign exchange markets. ${ }^{10}$ One notable anomaly is the failure of "uncovered interest parity," which states that the advantage of currencies with low nominal interest rates should be fully off set by currency appreciation. Table 4.5 presents a simple implementation of this result. Every month, a decision is made whether or not to hedge in the foreign bond market. If the forward premium is negative, implying that the foreign short-term interest rate is higher than the domestic rate, the decision is to hedge, or buy the foreign currency. Table 4.5 shows the resulting cost from borrowing on an unhedged basis, on a hedged basis, and using active hedging. The last line shows that the gain from active hedging relative to an unhedged position can be substantial, on the order of 1 percent a year.

Of course, this strategy is not without risk. As explained before, it is subject to devaluation risk (although all of these are positions relative to a floating dollar). Model risk is also an issue, which is why it would be useful to repeat this exercise using simulations based on prior information only.

10 See, for instance, Froot and Thaler (1990). There is abundant academic literature on the topic that has attempted, so far without success, to explain the anomaly in terms of a rational risk premium. 
Similar strategies can be used for the active management of global bond portfolios. Ilmanen (1996), for instance, shows that international bond returns can be forecasted using a number of variables, including business cycle indicators, real bond yields, and term spreads. He also simulates a dynamic trading strategy that appears to add substantial value. In practical terms, a borrower can use this information to identify periods of time when yields in one particular country are abnormally low.

More generally, we realize that active strategies, both for currencies and bond markets, must be approached with caution. Our advice would be to diversify not only across market risks, but also across active strategies. Diversification should therefore be viewed in a wider context than the traditional mean-variance framework.

\section{Conclusions}

This paper has provided a survey of approaches to sovereign debt management. We argued that modern portfolio theory, which is traditionally applied from the viewpoint of maximizing returns to investors, can equally serve to minimize costs to borrowers while not assuming undue risks. A major advantage of this approach is that it provides a consistent framework for dealing with the objective function, projected returns, risks, correlations, and user-specified constraints. Active views can be explicitly taken into account.

This approach, however, presents some disadvantages. First, this is a one-period model that does not deal well with traditional asset and liability management issues, such as covering a known stream of cash outflows. The one-period model is also myopic in that it ignores long-term issues such as mean-reversion in exchange rates as well as the possibility that today's actions may be corrected by future actions. Finally, the mean-variance optimization model makes full use of model parameters. The question must be asked whether the parameters used in the optimization process are stable enough to serve as a basis for sovereign liability management. With these limitations in mind, we should recognize that modern portfolio theory, which is now increasingly applied to the investment process of global investors, can be equally useful for the management of sovereign debt. 


\section{References}

Claessens, Stijn, 1988, "The Optimal Currency Composition of External Debt," World Bank Policy, Planning, and Research Working Paper (Washington: World Bank).

— , 1992, "The Optimal Currency Composition of External Debt: Theory and Applications to Mexico and Brazil," World Bank Economic Review, Vol. 6, No. 3 (September), pp. 503-28.

de Fontenay, Patrick, Gian Maria Milesi-Ferretti, and Huw Pill, 1995, "The Role of Foreign Currency Debt in Public Debt Management," IMF Working Paper 95/21 (Washington: International Monetary Fund).

Froot, Kenneth, and Richard Thaler, 1990, "Anomalies: Foreign Exchange," Journal of Economic Perspectives, Vol. 4 (Summer), pp. 179-92.

Glen, Jack, and Philippe Jorion, 1993, "Currency Hedging for International Portfolios," Journal of Finance, Vol. 48 (December), pp. 1865-86.

Ilmanen, Antti, 1996, "When Do Bond Markets Reward Investors for Interest Rate Risk?" Journal of Portfolio Management, Vol. 22 (Winter), pp. 52-64.

Jorion, Philippe, 1994, "A Mean-Variance Analysis of Currency Overlays," Financial Analysts Journal, Vol. 50 (May), pp. 48-56.

- 1997, Value at Risk. The New Bencbmark for Controlling Market Risk (Chicago, Illinois: Irwin Professional).

Kritzman, Mark, 1993, "The Minimum-Risk Currency Hedge Ratio and Foreign Asset Exposure," Financial Analysts Joumal, Vol. 49 (September), pp. 77-78.

Kroner, Kenneth, and Stijn Claessens, 1989, "Improving the Currency Composition of External Debt: Applications in Indonesia and Turkey," World Bank Working Paper 150 (Washington: World Bank, International Economics Department).

1991, "Optimal Dynamic Hedging Portfolios and the Currency Composition of External Debt," Journal of International Money and Finance, Vol. 10 (March), PP. 131-48.

Michaud, Richard, 1989, "The Markowitz Optimization Enigma: Is Optimized Optimal?" Financial Analysts Journal, Vol. 45 (January), pp. 31-42.

Odier, Patrick, and Bruno Solnik, 1993, "Lessons for International Asset Allocation," Financial Analysts Journal, Vol. 49 (March), pp. 63-77.

\section{CInternational Monetary Fund. Not for Redistribution}




\section{Comments on de Fontenay and Jorion}

\section{Gregory Makoff}

66 Goreign Currency Liabilities in Debt Management" addresses

1 two main issues. First, how much foreign currency debt a country should have (if any). And second, if a country has foreign currency debt, what its composition should be. The first part discusses the selection of the currency composition of foreign currency debt from the point of view of countries that have foreign currency debt by necessity. The second part jointly addresses the issues of how much foreign currency debt a country should have and what its composition should be from the point of view of developed countries that have sufficient local markets to fund government liabilities, but that have the option to borrow in foreign currencies. The third part of the paper applies modern portfolio theory to discuss the selection of an optimal amount and denomination of foreign currency debt for a developed country, Australia.

\section{Comments on First Part}

The first part of the paper takes a largely macroeconomic approach. The authors suggest that the currency composition of debt can hedge the volatility of a country's terms of trade or debt-service ratio.

This approach importantly offers a clear procedure for relating balance of payments and financial market data to the selection of the foreign currency composition of a country's debt: "The currency composition of the external liabilities depends on the covariances among exchange rates and the covariances between exchange rates and net foreign exchange receipts."

However, as emphasized in the paper, "the practical limitations of this approach result from the fact that the relationship between exchange rates (or borrowing costs) and terms of trade changes are for many countries weak or unstable."

The authors' concern can be rephrased as the following question: Can a borrower perform a regression analysis of historical trade flows and borrowing costs and mathematically define an effective terms of trade hedge? 
The technical difficulties are:

- Data may not provide statistically significant measurements of key parameters.

- Data may indicate parameters that are unstable-which change dramatically period by period.

- Finally, world economic relations are continuously changing, so historical terms of trade data may not accurate\}y indicate future terms of trade relations.

Some observers also question whether a terms of trade hedge is an appropriate objective for a sovereign. These observers point out that a government should focus on hedging its own cash flows and allow private sector entities to take or hedge foreign exchange risks according to their own objectives. Some observers additionally question whether a sovereign could effectively implement a terms of trade hedge. To the extent the private sector of a country actively hedges exchange rate risks in transactions that are not publicly disclosed, the government may create risk by trying to hedge traderelated currency exposures, which have already been hedged.

I would draw as a general lesson of this section that, regardless of the actual use of macroeconomic figures in the determination of a liability portfolio structure, it is essential that a country's portfolio analysts have a clear understanding of balance of payments issues and how they directly or indirectly relate to government finances.

\section{Comments on Second and Third Parts}

The authors point out four rationales that countries may use to justify foreign currency borrowings:

- Access to a wider range of debt instruments and maturities.

- Macroeconomic hedging or budgetary hedging.

- Providing a policy signal that authorities will not attempt to reduce the value of domestic debt through inflation.

- Reducing borrowing costs and risks.

The authors suggest that the last point is the most relevant and important consideration for most developed countries. The authors further suggest that the mean-variance approach is an important analytical method by which borrowers can simultaneously calculate the amount of foreign debt a borrower should have and its currency composition. 
The mean-variance approach suggests a portfolio structuring process that "uses as inputs the cost of borrowing in various financial markets and the covariances between the various interest rates, exchange rates, and the whole debt portfolio." The analysis then seeks to use these inputs to calculate an "efficient set" or "efficient frontier" representing the locus of portfolios that minimize risk for a given cost level. As the authors show, a specific objective function including both cost and risk terms can be defined, which accounts for the relative risk aversion of the borrower.

The authors show that such analysis can be performed using either historical data or the liability manager's interest rate and foreign exchange rate forecasts. It is emphasized that constraints can be added and that it can be generalized to include macroeconomic hedging. As this method is well known, I limit my remaining comments to two major concerns I have about the appropriate application of this technology.

\section{First Concern}

In most cases, I doubt the value of mean-variance analysis to sovereign portfolio managers in deciding the amount of external as opposed to domestic currency debt. My concern relates to the fact that domestic currency debt is distinguished from borrowings in external currencies by a government's ability to print its own currency and a government's authority to tax in its own currency. This qualitative difference between domestic currency tiabilities and foreign currency liabilities challenges the validity of a portfolio optimization method that treats them on an equal footing.

From a risk management perspective, I emphasize that the decision to have external debt (and the amount of external debt) is a fundamental policy decision that should be determined by a thorough analysis of worst-case outcomes and risk tolerances, as well as the possible impact of international borrowings on the value of the country's currency and domestic interest rates.

\section{Second Concern}

I have a more limited concern that there are a reasonable number of situations in which a borrower will want to avoid the mean-

\section{(C)International Monetary Fund. Not for Redistribution}


variance approach as a method of determining the currency composition of external debt. As an example, consider the selection of the currency composition of a portfolio consisting of deutsche marks, French francs, Dutch guilders, and Belgian francs, and possibly Spanish pesetas and Portuguese escudos. The process of EMU makes it likely that these currencies will be unified in the next few years as the euro. I would be concerned about the following issue: A risk analysis or portfolio optimization using the risk/return parameters of the past five years is likely to be inappropriate for estimating the risks and relative costs going forward. One could try to handle this situation within the confines of the suggested mathematical model by adjusting correlation coefficients and volatilities using projected values, but as there are distinct scenarios for EMU from success to meltdown, it might end up that this technology is more cumbersome than usef ul in defining key portfolio parameters.

I offer these criticisms of the application of portfolio theory to debt portfolio structuring without meaning to suggest that the principle of portfolio diversification be ignored. A portfolio should in all cases have a well-diversified set of market risks. A sovereign should avoid making a big bet on the appreciation or depreciation of a specific currency, or on the rise or fall of rates in a specific market. The results of portfolio theory are sensitive to inputs, typically historical or projected risk/return parameters - which leads to the important result that a large speculative position could be justified by applying apparently view-neutral calculations. Conclusions based on portfolio theory should be tested under a wide range of assumptions, and significant portfolio constraints should be imposed both to guarantee a sufficient level of diversification and to enforce consistency with other portfolio objectives. 


\section{Sovereign Liability Management: An Irish Perspective}

\section{Paul Sullivan}

T

o set in context the discussion of Ireland's approach to debt

management, we start with a brief outline of the history and main features of Ireland's national debt. Against that background, we will go on to discuss the main elements of debt management in Ireland, outlining both the institutional approach and the main policy and constraint issues that impact Ireland's debt management.

\section{Context}

First, to put the discussion in context, I will outline briefly the main features of the Irish national debt. As can be seen in Figure 5.1, the debt amounted to about IR $\{29,912$ million at the end of 1996, then equivalent to about US $\$ 44,569$ million. Having risen sharply during the first part of the 1980s, with foreign currency-denominated debt accounting for a disproportionate share of the growth, the debt has grown relatively little in recent years and actually declined slightly between the end of 1995 and the end of 1996 .

Reflecting both this lower growth and the strong real growth of the Irish economy in recent years, the ratio of debt to GDP has declined substantially since 1990 (see Figure 5.2).

In comparative international terms, Ireland's indebtedness is now in line with the EU average; this reflects both the substantial decline in Ireland's debt-to-GDP ratio, but also the fact that the EU average itself has increased from about 60 percent to abuut 70 percent over the past few years. See Figures 5.3 and 5.4. 
Figure 5.1. Irish National Debt

(In billiens of Irish pounds)

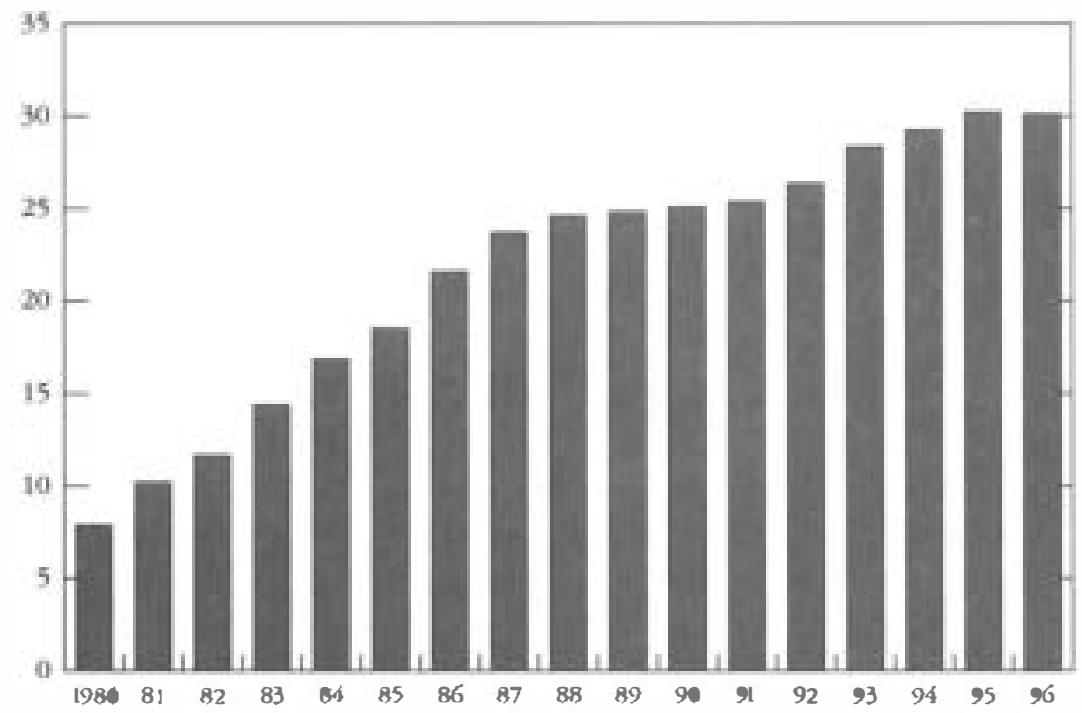

Source: National sources.

The cost of servicing the debt is shown in Figures 5.5 and 5.6, both in absolute terms and, perhaps more meaningfully, as a percentage of government current expenditure.

Figure 5.6 clearly shows the decline in the drain on national resources caused by the debt in recent years.

Finally, Figures 5.7 and 5.8 show the composition of the debt in terms of the main constituent elements and the currency breakdown.

Figure 5.7 shows the recent substantial improvement in Irish public finances. However, it also shows the much less favorable developments of the earlier 1980s, when with high annual budgetary deficits, the debt was growing at a rapid rate, both in absolute and in relative terms. The rapid growth in the foreign currency portion of debt in that earlier period gave rise to a particular increase in the market risk of the debt.

It was in this context that the Irish government decided to consider alternative institutional approaches to the management of the 
Figure 5.2. Irish Debt-to-GDP Ratio

(In percent)

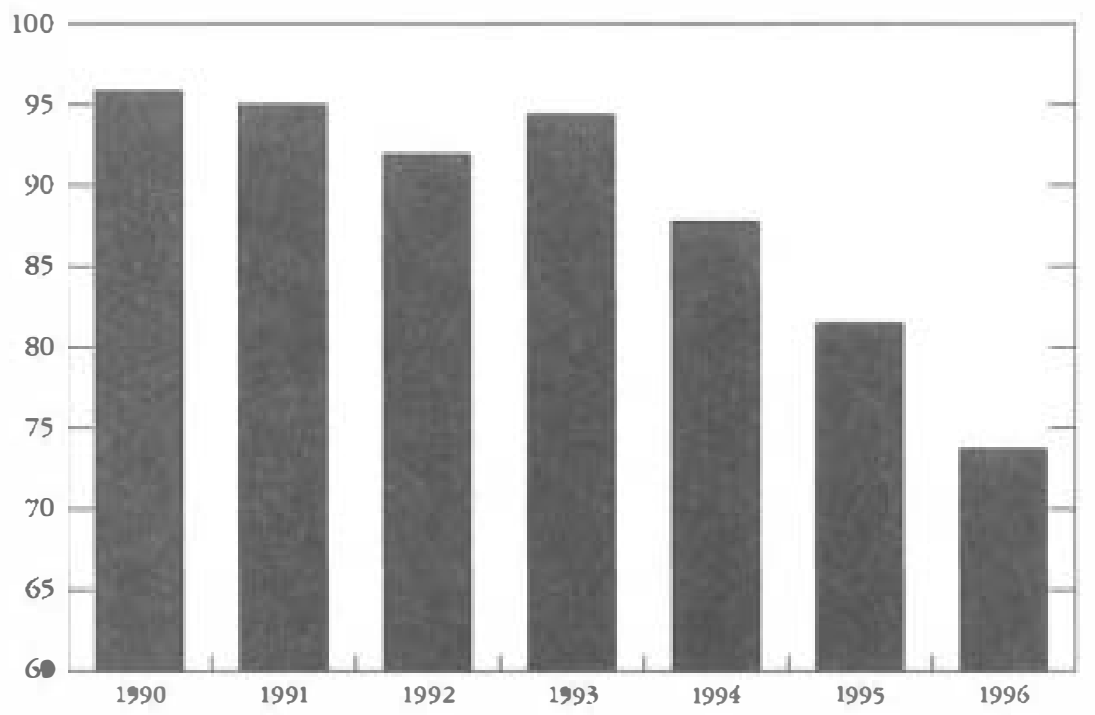

Source: National sources.

Note: The debt/GDP series on a Mastriclut basis only gees back as far as 1990.

debt, which ultimately led to the establishment of the National Treasury Management Agency, as well as to implement significant changes in fiscal policy.

\section{Debt Management in Ireland}

It was against this background of a rapidly growing and more complex debt that the National Treasury Management Agency was established in December 1990. Staff for the new agency were recruited from financial institutions both in lreland and abroad as well as from the Department of Finance. The Chief Executive of the agency reports directly to the Minister for Finance and is the Accounting Officer, responsible to the Dáil (Parliament).

The agency's principal functions are to fund maturing national debt and to fund the annual Exchequer Borrowing Requirement, in such a way as to protect both short-term and longer-term liquidity, contain the level and volatility of annual fiscal debt-service costs, 
Figure 5.3. General Government Debt-to-GDP Ratios of EU Member States, 1996

(In percent)

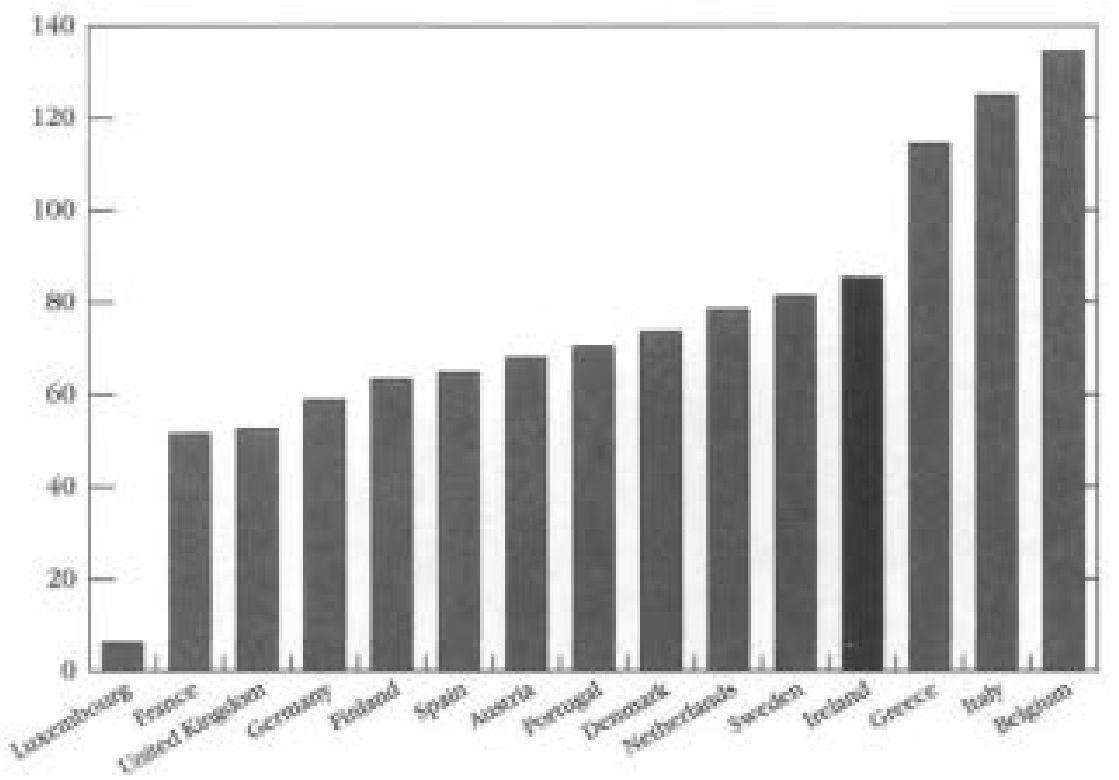

Source: European Commission.

contain the Exchequer's exposure to risk, and outperform a benchmark or shadow portfolio.

\section{Liquidity}

A key requirement of the agency is to ensure that future funding needs, arising from refinancing maturing debt as well as new Exchequer borrowing, can always readily be met. Ultimately, the protection of liquidity is the agency's most critical task. By consciously limiting the amount of debt maturing in any particular period as well as the cumulative level of maturities in the next several years, the agency seeks to contain the exposure to liquidity risk that might result from a shock to the financial markets, either domestic or foreign, arising from events having their origins related to or unrelated to events in Ireland.

Where, for particular reasons, there may be a concentration of maturities in a particular period, the agency will over time generally 
Figure 5.4. Ireland's Debt Relative to EU Average (Index)

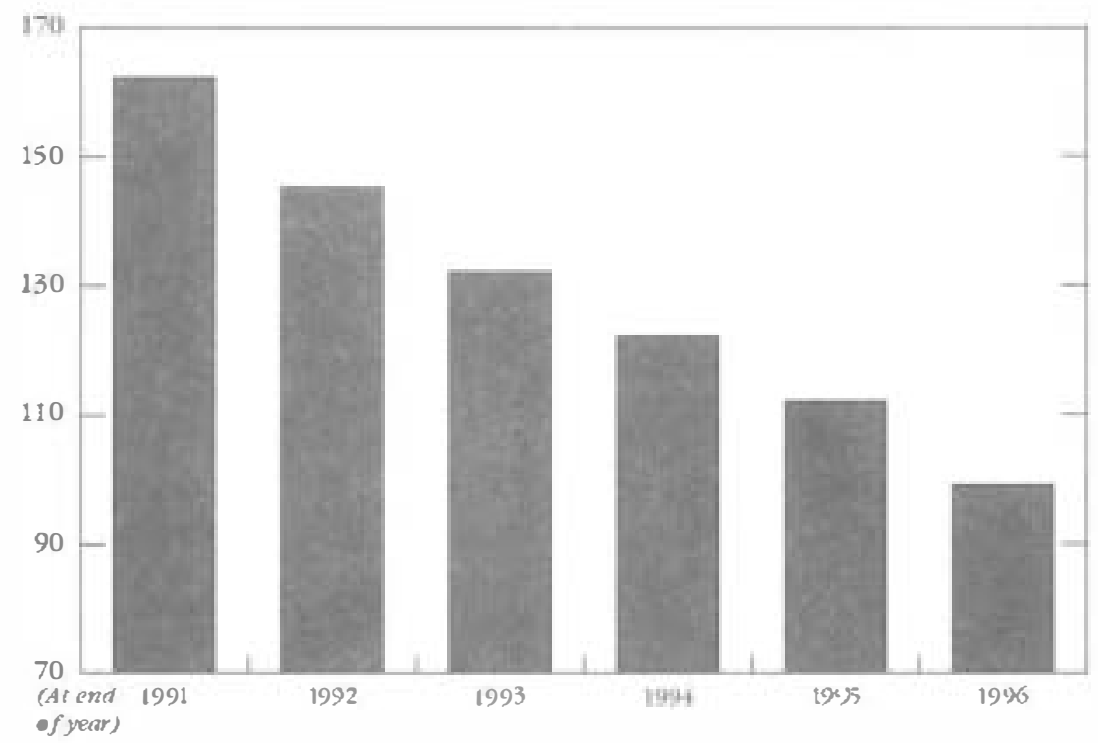

Source: European Commission.

look to refinance a portion of such debt to spread more eventy the pattern of maturities.

The maturity profile as of end 1996 is shown in Figure 5.9.

Liquidity risk relates to short-term liquidity as well as to the longer-term risk outlined above. The intrayear short-term liquidity risk is monitored and managed on an ongoing basis through a regular tracking process taking account of specific debt maturity dates and the expected seasonal profile of the Exchequer Borrowing Requirement. Detailed funding plans and related liquidity halances are prepared, reviewed, and updated regularly. In addition, short-term deposits as well as short-term paper issuance facilities, in both Irish pounds and foreign currency, are available to facilitate cash management.

\section{Debt-Service Volatility}

Notwithstanding the recent downward trend, debt-service costs still represent a significant call on Exchequer resources. As a resuit, 
Figure 5.5. Debt-Service Costs

(In billions of Irish posunds)

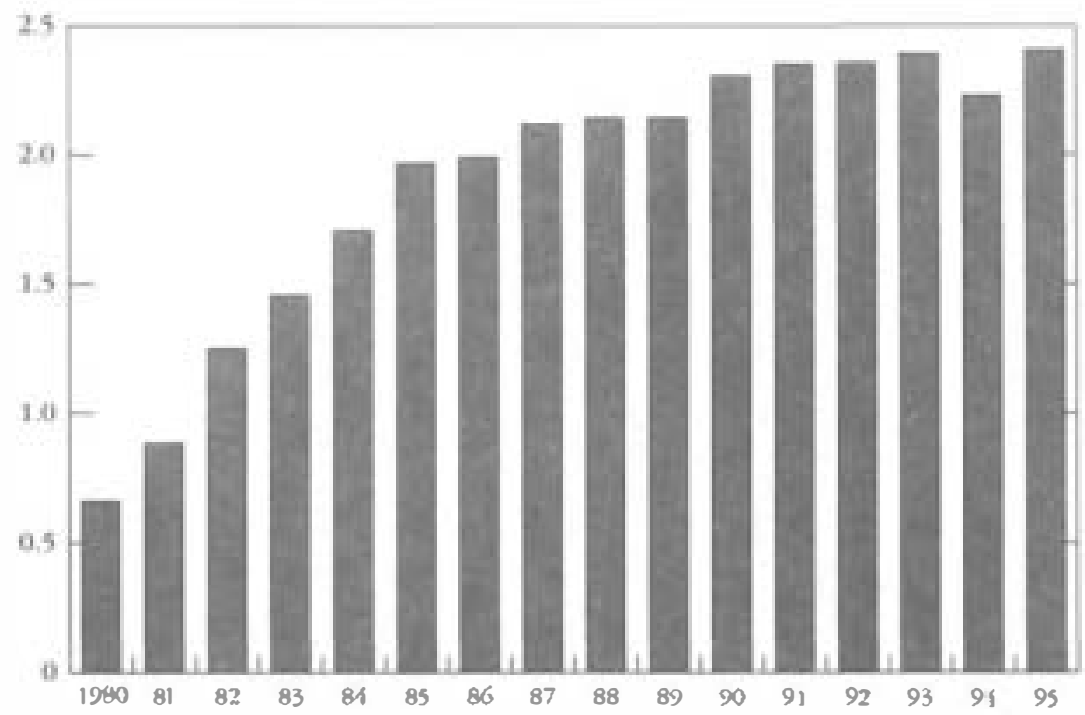

Source. National sources

containing the level and stability of such costs is an important policy objective. Inevitably, there is a trade-off between potential volatility of annual debt-service cost on the one hand. and volatility of the net present value (NPV) of the debt on the other hand. As the proportion of fixed rate and longer-duration debt is increased, the greater is debt-service stability over time; however. NPV volatility will increase.

There is no unique solution to this dilemma, and it is an area where the solution in practice may reflect the relative significance of the debt and the related debt-service costs to the Exchequer's financial position. In the case of Ireland, taking account of both the level of clebt-service costs as well as the decline that has taken place in Irish and international interest rates and bond yields over the past few years, there is a bias toward increased reliance on fixed rate deht, and some 64 percent of the debt was denominated in fixed rate liabilities at the end of 1996 . The breakdown of the debt between fixed and floating is shown in Figure 5.10.

The duration of the portfolio is shown in Table 5.1. 
Figure 5.6. Interest Bill as Percent of Total Government Current Expenditure

(In percent)

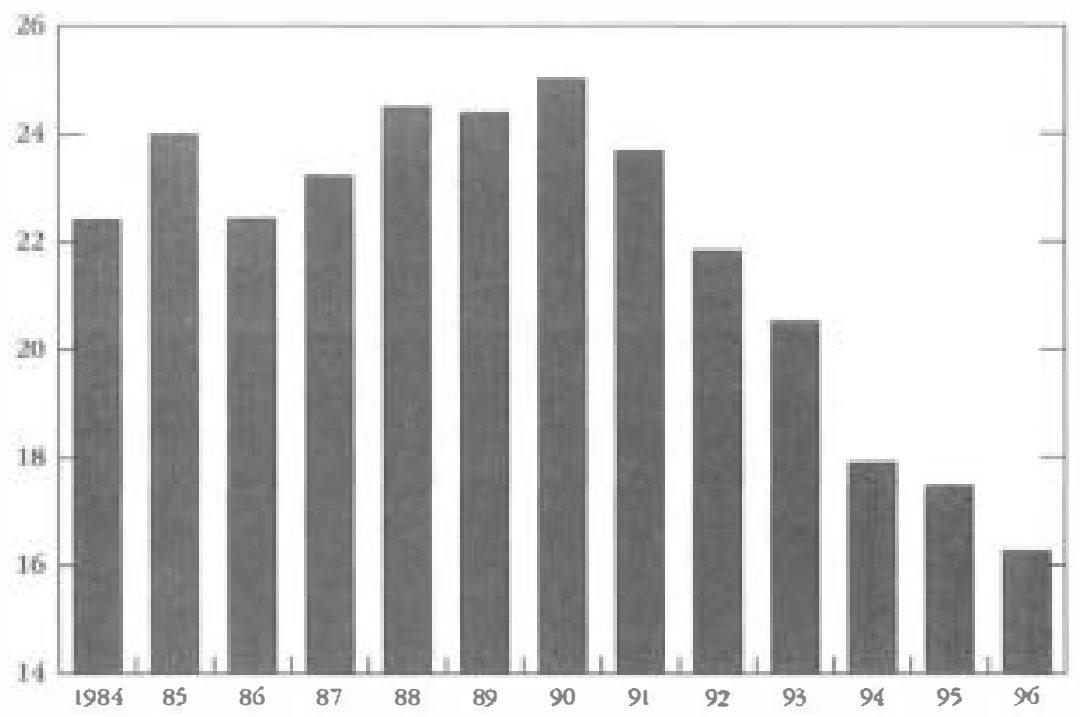

Surce: Natiunat suurces.

Note: The 1995 and 1996 figures exclude the extra nonbudgeted URE75 million and UR: 100 million payments to the National Savings interest Reserve.

Table 5.1. Portfolio Duration

(Years)

Inclucling STP. Excluding STP•

$\begin{array}{lll}\text { Domestic } & 3.99 & 4.14 \\ \text { Foreign } & 2.24 & 2.32 \\ \text { Total } & 3.36 & 3.50\end{array}$

*STP = Shor-term paper.

In managing the interest rate profile of the debt, the agency makes use of the derivative markets, particularly for the foreign currency portion of the debt, to achieve the desired fixed/floating mix while at the same time targeting the desired final maturity structure to achieve its liquidity objectives.

Given liquidity considerations and the long-term nature of the portfolio, it is to be expected that of the floating rate debt outstanding, most is of medium as opposed to short final maturity, with

\section{(C) International Monetary Fund. Not for Redistribution}


Figure 5.7. Composition of National Debt at the End of 1996 (In percent)

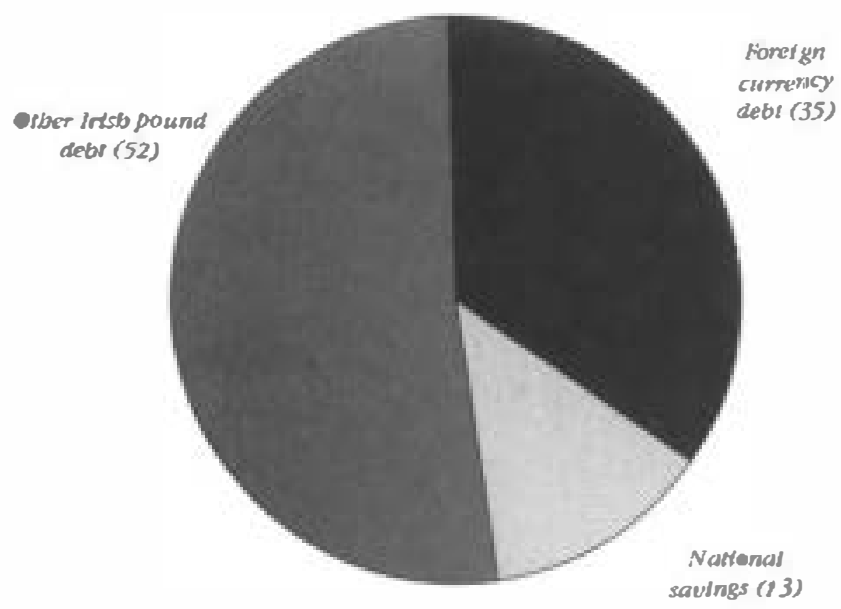

Source: National sources.

interest rate swaps being used to transform the interest rate profile of longer-dated, fixed rate liabilities as necessary. While the agency has, to date, primarily used interest rate swaps to eflect desired interest rate transformations, it is currently also introducing the use of bond futures contracts for this purpose.

\section{Risk Exposure}

The nature of the agency's debt management activities makes the management of risk a central and critical element of the agency's business. In addition to liquidity and debt-service risk considered above, the principal categories of risk arising from the agency's activities are:

- market risk;

- counterparty credit risk; and

- operational risk.

In all of these categories, the agency has put in place limits and control procedures to monitor and manage the risks involved. 
Figure 5.8. Currency Composition (In percent)

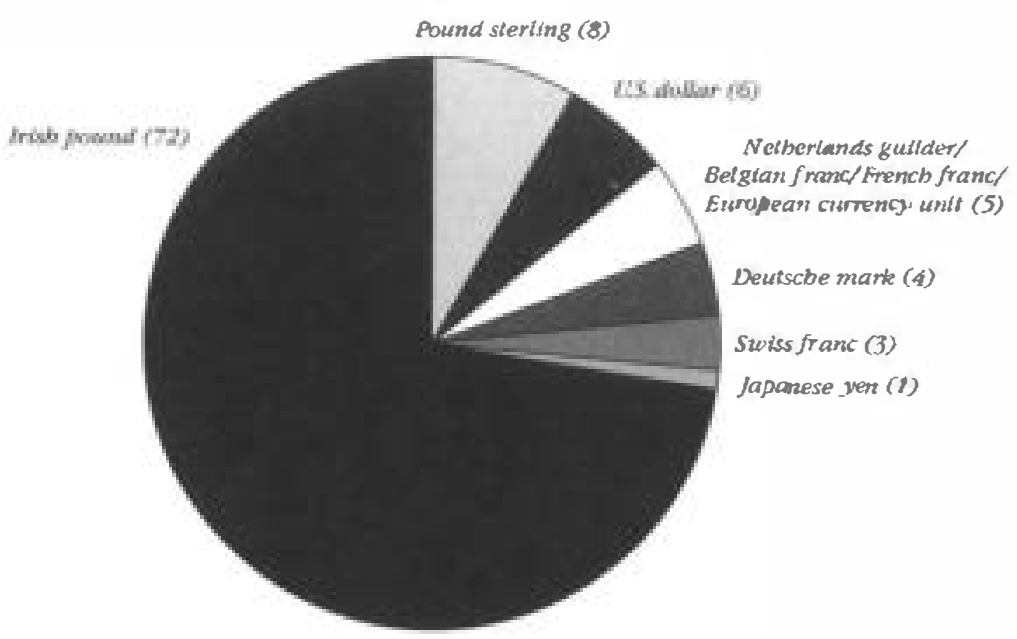

Source: National sources.

\section{Market Risk}

Market risk is the risk of a rise in debt-service costs and in the total market value of the debt owing to changes in interest rates or exchange rates. In conducting its debt management activities, the agency has to have regard both to medium- and short-term objectives, given its task of controlling not only near-term fiscal debt-service costs but also the present value of all future payments of principal and interest arising from the debt.

Liabilities in currencies that are within or closely related to the European exchange rate mechanism (ERM) normally carry less exchange rate risk than other currencies and, appropriately, account for the major portion of the foreign currency portfolio. However, exchange rate fluctuations within the permitted ranges of the ERM can give rise to material short-term fluctuations in the value of the foreign currency debt. Non-ERM currencies are also important in the portfolio and can be expected to remain so for reasons of current or expected cost, market presence, economic linkage, and portfolio diversification. 
Figure 5.9. Maturity Profile

(In billions of Irish pounds)

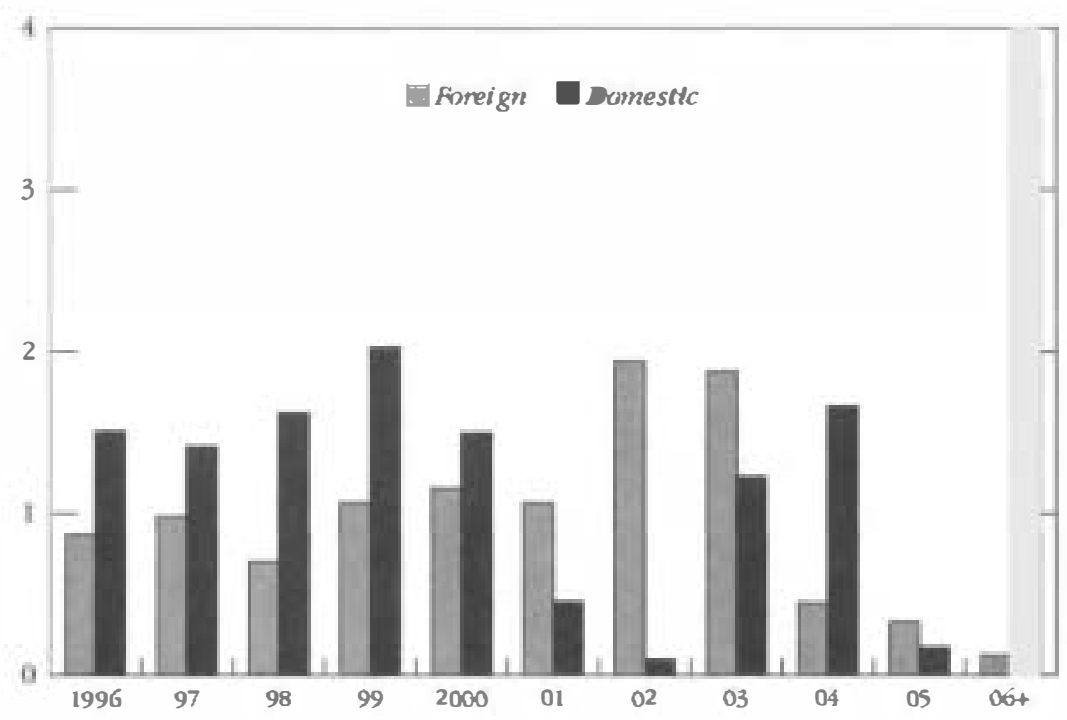

Sounce: National sources.

Borrowings in Irish pounds also carry market risk. Irish pound fixed interest rate borrowings are subject to a market valuation risk in the event of a decline in interest rates. While carrying less market valuation risk than fixed rate debt, floating rate borrowings carry a higher risk to the near-term fiscal cost of servicing the debt. The balance between fixed and floating rate liabilities has, therefore, to be managed for both the domestic and foreign currency portfolios.

The exposure to interest rate and currency risk, both for debt service and for the market value of the portfolio, is controlled through limiting the currency and interest rate concentration of the portfolio. The agency seeks to achieve the best trade-off between cost and risk over time. As conditions in financial markets change, the appropriate interest rate and currency profile of the portfolio is reassessed. 
Figure 5.10. Fixed/Floating Interest Breakdown of Debt (In billions of Irish pounas)

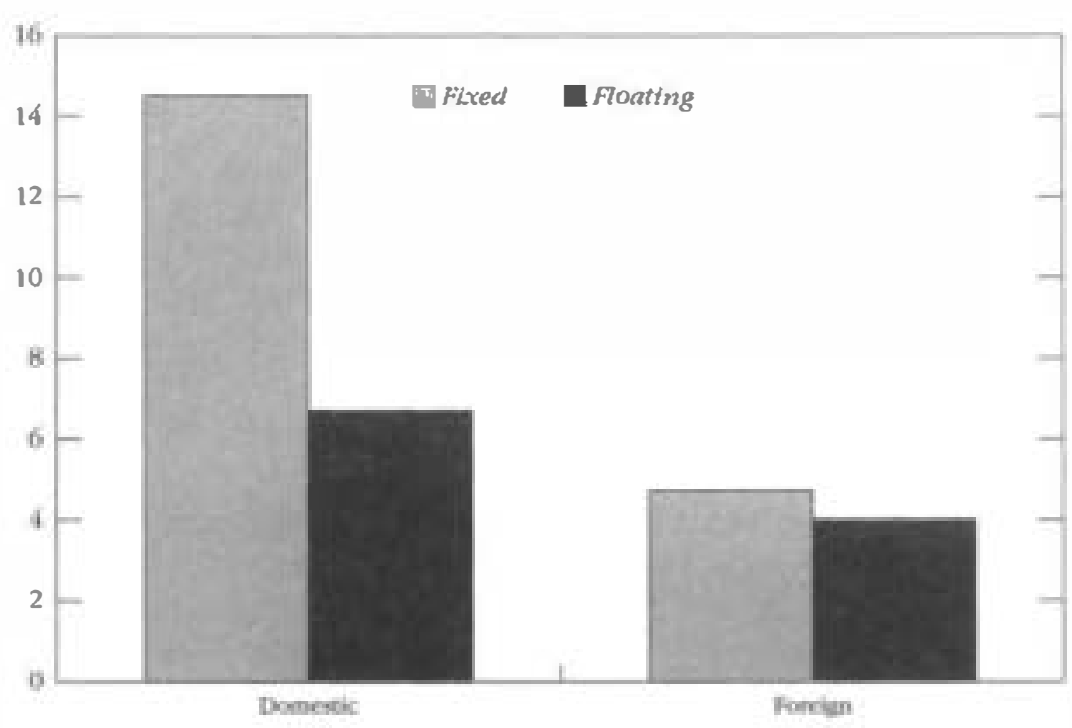

Sounce National sources

\section{Counterparty Credit Risk}

Derivatives, deposits, and foreign exchange transactions represent the principal product categories that give rise to counterparty risk exposures. Procedures are in place that provide for the approval of risk limits for all counterparties. For beyond one-year exposures, credit risk is normally restricted to AA-rated names or better. Exposures under these limits, calculated according to the nature of the underlying credit risk, are updated and reported daily to management. A review of all limits is undertaken periodically to take account of changes in the credit standing of counterparties or in economic and political events.

\section{Operational Risk}

Comprehensive controls have been established to ensure that operational risk is managed in a prudent manner. These controls include the segregation of duties between dealing, processing, pay-

\section{(C) International Monetary Fund. Not for Redistribution}


ments, and reporting. Prior to dealing in any new product, a product description must be prepared and approved by management; this product description identifies the product's inherent risks and documents appropriate processing and reporting procedures.

\section{Benchmark}

In carrying out its debt management activities, taking account of the liquidity, fiscal cost, and risk issues discussed above, the agency also has to pay particular regard to its performance and risk relative to the benchmark. The benchmark represents a shadow portfolio against which the cost of the real portfolio is measured. This measurement takes account not just of the payments actually made in the year in question but also the mark-to-market value, in Irish pound terms, of all future principal and interest payment liabilities that are undertaken by each portfolio. As such, the benchmark seeks to measure the full economic cost of all portfolio decisions rather than just their cash cost over a single year.

In using a benchmark, particularly if used for performance measurement purposes in addition to being used as a guide to portfolio management decisions, it is important to ensure that there is consistency between the rules governing the activity of the benchmark portfolio and the policy constraints and objectives that impact on the management of the actual portfolio. Given the importance of the annual debt-service budget, it is critical that the debt-service cost of the benchmark portfolio be consistent with the annual debt-service budget within which the agency must operate.

In the National Treasury Management Agency's case, the benchmark embodies a strategic target portfolio, which is reviewed annually and which represents a diversified and low-risk portfolio, aligned with the changing economic linkages of the Irish economy and the currency. Similarly, reflecting both the bias in favor of greater debt-service stability discussed above, as well as the view that the downward trend in global interest rates had already reached a relatively advanced stage, the benchmark incorporates a strategic bias toward a lengthening of its interest rate profile. The benchmark is, therefore, designed to be normative and to represent an inherently appropriate target portfolio profile. The benchmark should, therefore, in normal circumstances, serve as a strategic guide to the portfolio decision-making process. 
For this reason, it is important to keep the benchmark portfolio profile under review as circumstances change. As the benchmark is designed to represent appropriate strategic direction, it is not adjusted in tine with "normal" changes in market conditions, such as fluctuations in yields or exchange rates. It is, however, reviewed from time to time to reflect more fundamental changes in the context in which debt management is being carried out. Consequently, there is no fixed frequency for changing the benchmark. Toward the end of last year, a major review was undertaken, taking account of the planned introduction of EMU in 1999. A number of different EMU scenarios were considered, with the objective being to find portfolios that had cost and risk characteristics that were robust across a range of scenarios. The approach used in Ireland, therefore, is not one of looking for an "optimal" portfolio in a particular scenario, as such an approach can be dependent on scenarios and assumptions. Rather, by looking for a satisfactory combination of cost and risk across a range of scenarios, the analysis looks to establish a robustness in the benchmark, which we believe is important given its role as representing strategic policy direction.

In the above analysis to determine the appropriate currency and duration profile of the benchmark, it is necessary to define both "cost" and "risk." In the case of the Irish benchmark, cost, on the one hand, is measured in terms of net present value cost in Irish pound terms over a medium-term time horizon rather than in conventional government accounting terms. Risk, on the other hand, is measured in terms of ensuring a high probability that annual debtservice costs will not exceed budget, with an adjustment to take account of the impact of foreign exchange movements on the value of the debt.

The benchmark also takes on board the many reductions in the cost of debt achieved by the agency through its restructuring of the domestic market and its domestic and foreign portfolio switching and refinancing activities over the past five years. Because of this and the many efficiencies already implemented over the past few years, it will, however, be increasingly difficult to outperform the benchmark in the funure. Finally, it should be clearly understood that any benchmark remains an artifice that must reflect specific expectations as to the future market and strategic environment. Should the actual environment be materially different from what was expected, closely following any benchmark could result in suboptimal decisions. 
Operationally, the benchmark portfolio is computerized and the performance and market risk of the actual portfolio relative to the benchmark is networked daily to the desktop personal computers of portfolio managers and to senior management.

In addition to measuring NPV sensitivities to movements in market rates, there is a separate risk analysis tool, used by the agency in managing its exposures to movements in interest rates and exchange rates-a personal computer model that captures the sensitivity of fiscal debt-service costs in any particular period to any selected movement in particular interest rates or exchange rates. As a result, the agency can analyze the potential impact on interest costs of a number of scenarios and take action, as appropriate, to reduce the level of exposure in a particular period.

\section{Foreign Currency Debt}

Foreign currency liabilities accounted for about 28 percent of the debt at the end of 1996. This compares with 35 percent at the end of 1990 , and 38 percent at the end of 1992 . The reduction in the proportion of foreign currency-denominated debt reflects the policy of making net repayments of foreign debt in each of the past few years to the extent of maturing foreign currency debt.

Within the foreign currency liability portfolio, and reflecting the considerations outlined in the earlier discussion on risk and the benchmark, the currency composition is well diversified. The selection of currency mix, as with the benchmark, in large part reflects the considerations of risk, with the heaviest collective weighting being in EU currencies. Within that grouping, there has been a greater level of diversification and over the four-year period to the end of 1996 , the proportion of debt denominated in sterling and French francs was increased from less than 2 percent to 42 percent. Over the same period, the proportion of debt in deutsche marks, Dutch guilders, and Swiss francs fell from 69 percent to 27 percent. In managing the currency risk associated with the foreign debt, the agency seeks to strike a balance, taking account of linkages with the Irish pound, between the cost and risk of different currencies.

Figure 5.11 shows the currency composition and interest rate mix of the debt. 
Figure 5.11. Foreign Debt Currency Composition at the End of 1996

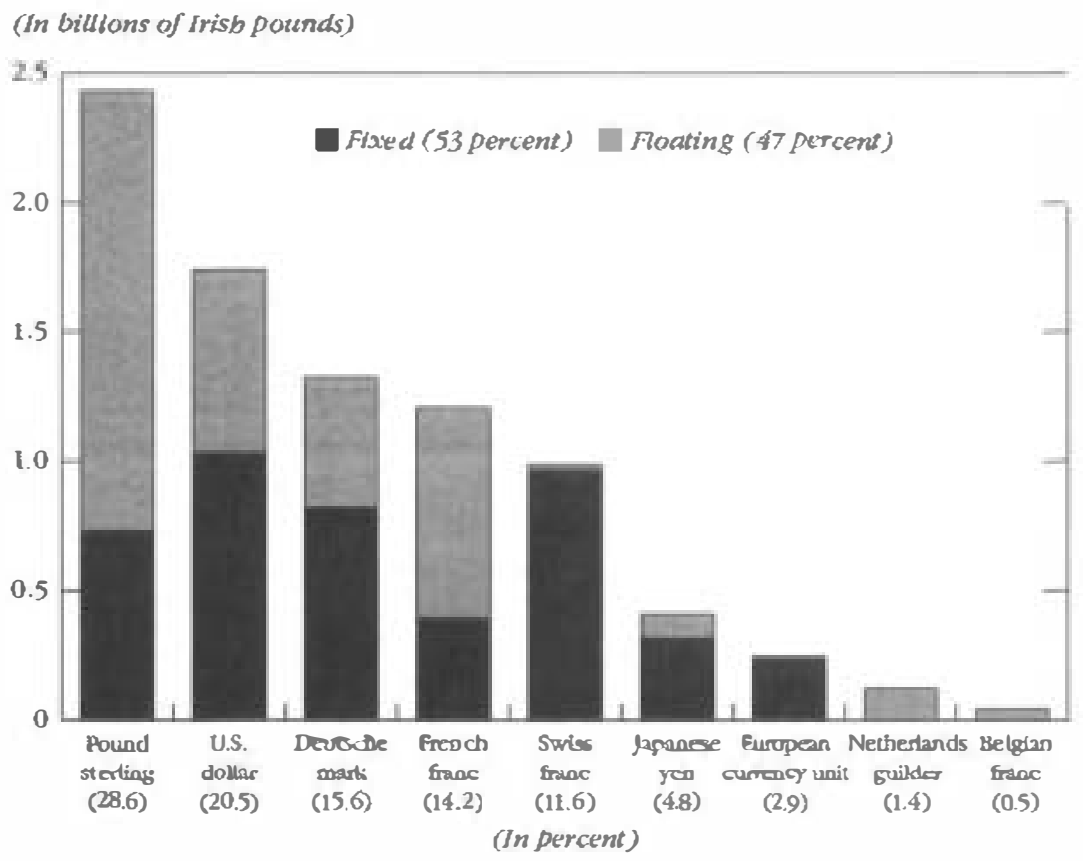

Source: National sources.

To a considerable extent, the target currency profile is set independently of near-term maturities and borrowing opportunities, although these considerations clo impact the pacing at which any desired currency profile is achieved in order to contain both transaction costs and credit exposure associated with derivatives. In looking to generate liabilities in a particular currency, the agency will usually examine both direct and indirect ways of doing so and frequently takes advantage of swaps or other arbitrage-driven structures to achieve both currency and pricing targets.

\section{Domestic Bond Market}

A major focus of the agency continues to be on the fisrther development of the liquidity and efficiency of the Irish pound bond market. Toward this end, the agency has introduced a number of measures in recent years including the establishment of benchmark 
issues and, more recently, the introduction of a primary dealer system. Benchmark bonds exist in, or close to, the 5-, 10-, and 20-year maturities with new benchmark bonds being introduced periodically. During the course of 1995, two new benchmark bonds5-year and 10-year-were launched, while in 1996, a further new 5-year bond was introduced.

\section{Market Making in Government Bonds}

In December 1995, the agency introduced a formal primary dealer system to replace the agency broker system for dealings in government bonds. The purpose was to bring the bond market structure in Ireland more in line with competitor countries and to improve liquidity, thereby reducing funding costs.

Each primary dealer dedicates between IR£5 million and IR\&8 million capital to market making in Irish government bonds on an ongoing basis and is expected to contribute to the agency's gross funding program broadly in line with its share of retail market turnover. Primary dealers quote firm bid and offer prices in a specified list of bonds within agreed size and spread parameters. Investors can be conf Ident in obtaining buy and sell prices on a continuous basis.

\section{Investor Relations}

With regard to both Irish pound and foreign currency funding, the agency plays an active role in developing and maintaining investor relations. The agency, both independently and also together with both Irish and foreign-based brokers and investment banks, has held a number of investor marketing meetings in a wide range of locations in Europe, Japan, and the United States. With approximately 50 percent of the debt held by nonresidents, the agency recognized the importance of maintaining active contact with all major international investor groups. The agency also maintains close communications with all the major rating agencies to ensure they are kept fully informed of all major developments in the Irish economy and on Ireland's economic and debt management policy. The growing importance of the Irish government bond market to global investors is underlined by the inclusion of the bonds in major international bond indices. 


\title{
Management of Risks in Foreign Currency Funding and Debt Management
}

\author{
Bengt Rådstam
}

7 he Kingdom of Sweden is represented in international capital as the SNDO. The SNDO is a government authority reporting to the Ministry of Finance. As a separate debt office outside the Ministry of Finance and the central bank, the SNDO has a professional organization devoted only to government debt-specific issues. Apart from executing funding operations in both Swedish krona and foreign currencies, the SNDO also actively manages the debt through the use of derivatives markets.

Following the removal of a norm preventing borrowing in foreign currencies in the autumn of 1992, the SNDO has been one of the largest, if not the largest, borrower in the international market. Large funding programs over recent years have increased the size of the foreign currency debt portfolio from about $\$ 8$ billion at its lowest level prior to September 1992, to more than $\$ 60$ billion today. During this period, the SNDO has received yearly mandates from the Ministry of Finance indicating the desired level of funding in foreign currencies during the following year. In view of the rapidly declining central government borrowing requirement and the healthy surplus in the balance of the current account, the government then stipulated that there should be no net borrowing in foreign currencies during 1997. However, with foreign currency loans in excess of $\$ 7$ billion maturing during 1997, gross borrowing was still quite sizable. 
The overriding objective of the SNDO's foreign currency operations is to minimize the long-term cost of the foreign currency debt. This should be accomplished within the risk limits established by the board of the SNDO. The most important risks are market risk, credit risk, and refinancing risk.

\section{Market Risk}

\section{Structure of the Benchmark Portfolio}

The board of the SNDO decides on a benchmark portfolio and on the extent to which the actual debt portfolio may differ from the benchmark portfolio. There are five essential requirements on the benchmark portfolio:

(1) The benchmark portfolio should be reasonably diversified;

(2) It should not incorporate any expectations regarding the direction of currency or interest rate movements other than those already discounted by the markets;

(3) The benchmark should be consistent with some clearly stated objectives. It should not be changed unless the continuing fulfillment of the objectives make such a change necessary, or the objectives themseives were to be changed;

(4) In terms of an actual debt portfolio, it should be possible to replicate or at least come close to the benchmark portfolio without incurring prohibitively high transaction costs;

(5) It shouid be possible to distinguish between the cost savings resulting from the active management of the debt and the cost savings emanating from the activities on the funding side. In other words, the SNDO's performance in relation to the benchmark should not be sensitive to the margin below U.S. dollar LIBOR at which the debt has been raised.

By reflecting the prevailing currency regime in Sweden, the currency composition of the benchmark is designed to minimize the fluctuations in the currency component of the total cost of the foreign debt. From the beginning of 1990, when the benchmark portfolio was established, until May 1991, the benchmark weightings were identical to the weightings in the currency basket to which the Swedish krona was then tied. During the period when the krona was tied to the theoretical ECU, from May 1991 to November 1992, 
the weightings reflected the composition of the theoretical ECU. When the krona started to float in November 1992, it was decided that the U.S. dollar, with a weighting of 12 percent, and the yen, with a weighting of 6 percent, should be included in the benchmark portfolio, and that the remaining 82 percent should still be split according to the composition of the theoretical ECU.

The benchmark for the interest rate sensitivity of the foreign debt has not been subject to any changes since its inception in 1990. The underlying objective is to maximize the likelihood of an average outcome in terms of the total cost of the debt by having half of the debt at floating rates and the other half at fixed rates with maturities of one, three, five, seven, and 10 years in equal proportions. Such a split between floating rate debt and fixed rate debt will produce a modified duration of approxinately 2 percent. If market interest rates are low or high, the modified duration of the debt will be somewhat higher or lower than 2 percent. The floating rate portion is then increased or decreased (such as from 50 percent to 53 percent or from 50 percent to 47 percent). In this way, the benchmark for the modified duration of the debt will always be 2 percent.

To aim at only an average outcome in terms of cost may sound a little defensive. However, the chosen benchmark can be thought of as an insurance policy or guarantee that there will always be a reasonable outcome, while the SNDO retains the opportunity to outperform the benchmark portfolio by using its mandate to manage the debt actively.

\section{Risk Limits}

The purpose of active debt management is to achieve a lower cost of debt, over the long term, than that of the benchmark portfolio. The SNDO is, therefore, allowed to take currency and interest rate positions in relation to the benchmark portfolio within risk limits laid down by the board.

The risk limits stipulate that the proportion of the debt in any one currency should be equal to the corresponding proportion in the benchmark portfolio, with a deviation of 3 percentage points in either direction. With foreign currency debt in excess of $\$ 60$ billion, the actual exposure in an individual currency could thus differ from the corresponding exposure in the benchmark portfolio by the equivalent of close to $\$ 2$ billion. 
In the case of interest rate risk, the maximum permitted deviation from the benchmark portfelio's motified duration of 2 percent is 0.5 percentage points. For example, if the SNDO were to decide to increase the modified duration of the debt from 2 percent to 2.5 percent, this would require selling $\$ 4.5$ billion worth of 10 -year interest rate futures, or entering into approximately 50 interest rate swaps, each with a size of $\$ 100$ million and with a maturity of 10 years, or a combination of futures and interest rate swaps in various maturities and currencies. For any one currency, the interest rate risk measured in Swedish krona may deviate from the corresponding interest rate risk in the benchmark portfolio by no more than 0.2 percent of the total debt.

The risk limits have been designed so as to give the SNDO ample scope to outperform the benchmark portfolio without taking any extreme currency or interest rate positions. Admittedly, the limits are set up in a rather unsophisticated way with no consideration as to correlations and volatilities. As the SNDO is in the process of upgrading its software, a changeover to a value-at-risk (VAR) based method of handling market risk is now uncler consideration.

\section{Result of Active Management of Foreign Currency Debt}

Since the benchmark portfolio consists of a number of hypothetical transactions, it is possible to calculate the total cost of this portfolio in the same way as for the actual debt portfolio. By comparing the costs of the two portfolios cluring a certain period, it is easy to see whether the SNDO has gained or lost from taking positions within the set risk limits.

During the last five years, the active management of the foreign currency debt has resulted in savings of approximately SKr11 billion, or about 4 percent of the average level of debt during this period. The overwhelming part of those savings can be attributed to interest rate positions in relation to the benchmark portfolio. Currency positions have contributed less than 20 percent to the result.

To make it easier for the board to evaluate the results achieved by the SNDO, an arrangement involving a limited number of external managers has been in place since the beginning of 1992. Each external manager involved in this scheme has been given a mandate to manage a small proportion of the foreign currency debt on the

\section{CInternational Monetary Fund. Not for Redistribution}


same principles and under the same rules as apply to the SNDO's own management. The performance of each external manager is constantly monitored and a manager who clearly underperforms nuns the risk of being replaced.

In Table 6.1, the performance of the SNDO is compared with that of the external managers. As can be seen from the table, the average monthly result during the last five years amounted to a saving of $61 / 2$ basis points for the SNDO and $11 / 2$ basis points for the group of external managers. However, with an average monthly result of 4 basis points, one manager had a much better result than the other external managers. The most important factor behind the SNDO's outperformance was its much more aggressive positioning in the falling interest rate environment of 1993.

As shown in Table 6.1, the standard deviation of the monthly results has been higher for the SNDO than for the external managers. This may be due to the fact that the size of the SNDO's portfolio makes it difficult to adjust the portfolio during periods of turbulence on the international markets. Table 6.1 also shows the result in terms of return for risk undertaken. On this measure-the so-called Information ratio or Adjusted Sharpe ratio-the score for SNDO is 0.88 and that for the external managers is 0.36 .

When assessing the performance of the SNDO in comparison with the external managers, a number of considerations should be taken into account. The SNDO has been managing the debt against its custom-built benchmark since 1990, and it may take some time for the external managers to get used to this particular benchmark. The most important advantage relating to the arrangenent involving external managers, however, is probably that the SNDO has been exposed to competition from high-ranking fund managers.

Table 6.1. SNDO's Portfolio Performance. January, 1992-December 1996

\begin{tabular}{lccc}
\hline & SNDO & $\begin{array}{c}\text { The Best } \\
\text { Performing } \\
\text { External } \\
\text { Manager }\end{array}$ & $\begin{array}{c}\text { Average } \\
\text { Among the } \\
\text { External } \\
\text { Managers }\end{array}$ \\
\hline Average monthly results in basis points & 6.5 & 4.1 & 1.6 \\
Highest monthly result in basis points & 89 & 61 & 53 \\
Lowest monthly result in basis points & -62 & -46 & -26 \\
Standard deviation in basis points & 26 & 21 & 16 \\
Months with positive results & $68 \%$ & $55 \%$ & $53 \%$ \\
lnformation ratio (based on annualized) & 0.88 & 0.69 & 0.36
\end{tabular}


This competition is probably an impontant factor behind the good results of the active management of the foreign currency debt.

\section{Funding in Foreign Currencies}

The SNDO tries to achieve cost efficiency by funding in markets where there is a strong investor demand. By providing investors with the investments they are looking for, rather than selling a product that suits only the SNDO's internal requirements, the SNDO should achieve more cost-competitive funding.

The strategy in approaching different markets is one of relative value. To determine what is competitive funding, the SNDO evaluates opportunities in relation to the equivalent U.S. dollar LIBOR cost of any funding structure. This approach requires the flexibility to be able to access all markets at all times. This can be done because of the separate liability management, which transforms the exposure of the liability portfolio to fit the SNDO's internal requirements. As shown in Figure 6.1, the currency composition of the outstanding debt before liability management is quite different from that of the debt after liability management.

As can be seen in Table 6.2, this liability management involves a large-scale use of derivative transactions.

There is also a fair amount of financial futures and options in the portfolio. The SNDO's view on the advantages and disadvantages with the different derivative instruments that are used in the management of the market risk is summarized in the concluding appendix.

Table 6.2. Outstanding Debt and Derivative Transactions, November 29. 1996

\begin{tabular}{lc}
\hline & Market Value in Billions of U,S. Dollars \\
\hline Loans & 62.5 \\
Swap assets & 73.4 \\
Swap liabilities & 73.8 \\
Foreign exchange forwards as.set.s & 26.0 \\
Foreign exchange—liabilities & 26.0
\end{tabular}


Figure 6.1. Foreign Currency Debt Composition as of November 29, 1996 (In percent)

Before derivatives transactions

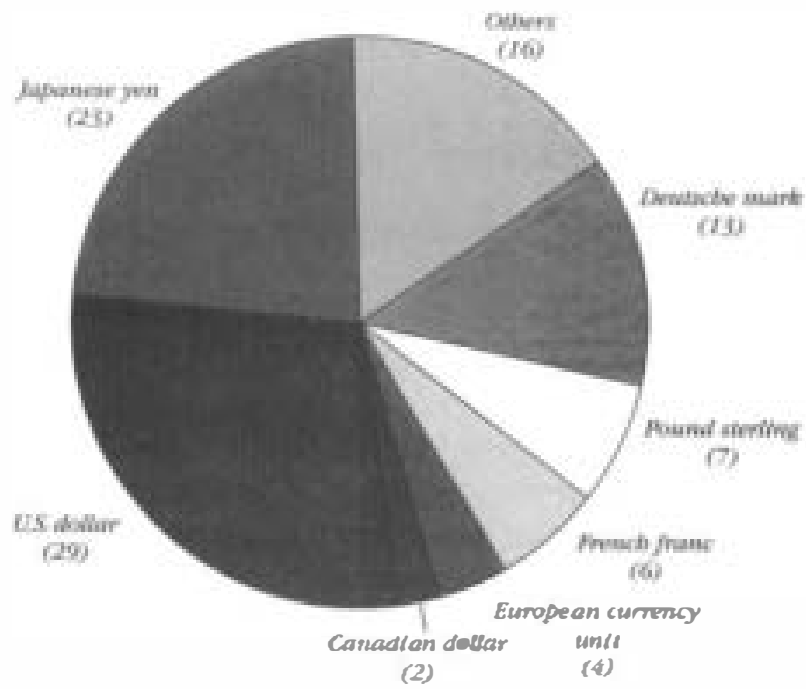

After derivatives transactions

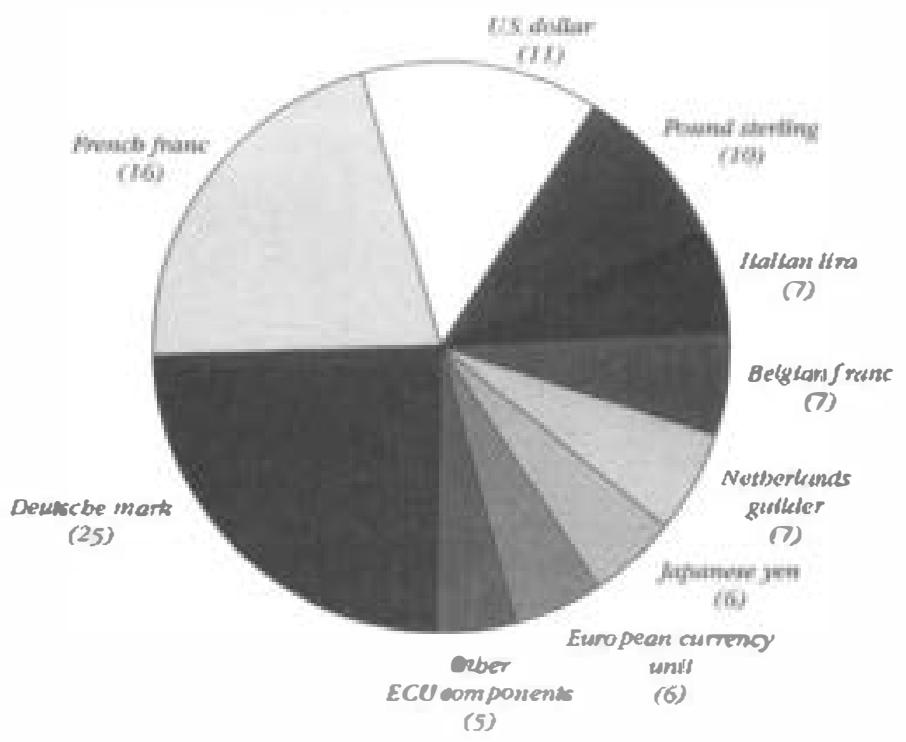

Source National sources. 


\section{Credit Risk}

The SNDO's large-scale use of derivative products necessitates a well-developed model for managing counterparty credit risk. The main features of the model used by the SNDO are as follows.

\section{Acceptable Counterparties}

The main criterion for accepting a counterparty is credit rating performed by well-known rating agencies. Information about credit rating is collected from at least two rating agencies. Generally, longterm rating is applied for all transactions regardless of maturity. However, if a counterparty, for transactions with maturities below one year, does not have a long-term rating, the highest short-term rating $(\mathrm{P}-1 / \mathrm{A}-1+)$ from at least two rating agencies is required. If a counterparty only has a rating from one agency, the rating is reduced by one step. If a counterparty has a split rating, the second best rating applies. Ratings below A3 / A- are never accepted. Since credit risk increases by the maturity of a transaction, higher rating is required the longer the maturity, as shown in Table 6.3.

As mentioned above, rating is the main criterion for accepting counterparties. It is, however, not the sole criterion. In addition, an individual assessment of each counterparty is undertaken, whereby factors such as rating history, capital size, and legal construction (mainly refers to entities within the same legal sphere) are taken into account. These factors are part of the total evaluation of a counterparty.

Table 6.3. Accepted Ratings by Maturity

\begin{tabular}{lccccccc}
\hline & $<7$ days & $<1 \mathrm{mch}$ & $<1 \mathrm{yr}$ & $<5 \mathrm{yr}$ & $<10 \mathrm{yr}$ & $<15 \mathrm{yr}$ & $>15 \mathrm{yr}$ \\
\hline $\mathrm{Aaa}$ & $\mathrm{x}$ & $\mathrm{x}$ & $\mathrm{x}$ & $\mathrm{x}$ & $\mathrm{x}$ & $\mathrm{x}$ & $\mathrm{x}$ \\
$\mathrm{Aa1}$ & $\mathrm{x}$ & $\mathrm{x}$ & $\mathrm{x}$ & $\mathrm{x}$ & $\mathrm{x}$ & $\mathrm{x}$ & \\
$\mathrm{Aa2}$ & $\mathrm{x}$ & $\mathrm{x}$ & $\mathrm{x}$ & $\mathrm{x}$ & $\mathrm{x}$ & & \\
$\mathrm{Aa3}$ & $\mathrm{x}$ & $\mathrm{x}$ & $\mathrm{x}$ & $\mathrm{x}$ & & & \\
$\mathrm{A} 1$ & $\mathrm{x}$ & $\mathrm{x}$ & $\mathrm{x}$ & & & & \\
$\mathrm{A} 2$ & $\mathrm{x}$ & $\mathrm{x}$ & $\mathrm{x}$ & & & & \\
$\mathrm{A3}$ & $\mathrm{x}$ & $\mathrm{x}$ & $\mathrm{x}$ & & & & \\
\hline
\end{tabular}




\section{Counterparty Credit Risk}

In the SNDO credit risk model, counterparty credit risk is defined as follows:

counterparty risk $=$ risk of default $*$ (actual exposure + potential exposure)

Figures for risk default are retrieved from statistics on cumulative default rates from rating agencies. The risk of default is then multiplied by the sum of actual and potential exposure on a transaction basis. The calculated product is the counterparty risk. The amount of counterparty risk can be interpreted as the value of the credit risk of a transaction. By using counterparty credit risk, as defined above, a relatively simple limit model is enabled. The limits are set on counterparty credit risk and not on exposure.

Limits on counterparty credit risk include both limits on individual counterparties and a limit on the total portfolio. Setting a limit on the total portfolio creates an incentive to use counterparties with high creditworthiness. A transaction with an AAA-rated counterparty will add less to credit risk than an identical transaction with an Arated bank. By choosing counterparties with high ratings, there will be more room for new transactions-that is, the allowed amount of credit risk will be used more efficiently.

It is also necessary to have an individual limit on each counterparty to avoid concentration of counterparty risk to a small number of counterparties. However, since the default risk is higher for an A-rated counterparty than for an AAA-rated counterparty, the limits on the Arated counterparty will be reached more rapidly. Also, the longer the maturity of a transaction, the faster the limit will be reached.

\section{Potential Exposure}

The total exposure of a transaction is the sum of the actual and the potential exposure. The actual exposure is the mark to market of the transaction at current market rates. If market rates change, the market value of the transaction will change. This potential change of exposure is taken into account by adding a factor (add-on) to the actual exposure.

The SNDO uses the add-ons proposed by the Basle Committee in April 1995 (see Table 6.4). The add-ons are multiplied by the notional principal amount and added to the actual exposure.

\section{(C)International Monetary Fund. Not for Redistribution}


Table 6.4. Add-Ons for Potential Exposure

\begin{tabular}{lccc}
\hline Residual Maturity & Interest Rate & Exchange Rate & Other \\
$\geq 1 \mathrm{yr}$ & $0.0 \%$ & $1.0 \%$ & $10.0 \%$ \\
$1 \geq 5 \mathrm{yr}$ & $0.5 \%$ & $5.0 \%$ & $12.0 \%$ \\
$>5 \mathrm{yr}$ & $1.5 \%$ & $7.5 \%$ & $15.0 \%$
\end{tabular}

Source: Basle Capital Accord: Treatment of Potential Exposure for Off-Balance items, Basle Committee on Banking Supervisjon, Basle, April 1995.

The add-ons only reflect the potential variation of the market value of the portfolio under normal market circumstances. Therefore, the SNDO also regularly performs stress tests to determine what effect extreme market conditions would have on the portfolio.

\section{Refinancing Risk}

Apart from the cost aspect, it is important to create a maturity profile that does not expose the SNDO to unreasonable refinancing risks in the future. SNDO is concerned both by the shape of the maturity profile and the size of absolute redemptions during any given time period. The ideal redemption profile should slope so that higher redemptions are stacked at the short end and then level off. Depending on the absolute size of the debt portfolio, the period over which the redemptions are spread can be shorter or longer. As the underlying debt is now quite large, the SNDO needs to spread redemptions not only over the next few years, but over the entire spectrum of liquid maturities in most capital markets-at least out to 10 years.

The SNDO is using a simple model for the calculation of a target maturity profile. First there is an assessment of investor demand in various maturities. The SNDO assumes (with some empirical support) that international investors wish to allocate their capital in the manner shown in Table 6.5.

Table 6.5. Target Maturity Profile

$\begin{array}{cc}\text { Maturity is Years } & \begin{array}{c}\text { Percentage of Total } \\ \text { Allocated Capital }\end{array} \\ 1 & 5 \\ 3 & 15 \\ 5 & 35 \\ 7 & 10 \\ 10 & 25 \\ 15 & 10\end{array}$


Now, assume that the SNDO allocates its funding in an identical manner and that the funding remains at a constant level each year. Eventually, after a number of years, the maturity profile will take the shape of what is called the target profile in Figure 6.2. (Going into 1997 the target profile will move one step to the right, that is, it will start at 1998 instead of 1997.) This profile has three important characteristics from the SNDO's point of view:

- It is consistent with a rational and perfectly feasible long-term funding policy.

- The average maturity of the debt will be reasonably long. (With the assumptions used by the SNDO, it will be $4 \frac{1}{2}$ years.)

- An equal percentage of the debt will fall due each year. (With the assumptions used above, this figure amounts to approximately 15 percent.)

Depending on the size of actual redemptions in each maturity, the SNDO will value borrowing opportunities differently depending on tenor to create the maturity profile the SNDO desires. Funding op-

Figure 6.2. Foreign Currency Debt Maturity Profile as of December 19, 1996

(In billtons of U.S. dollars)

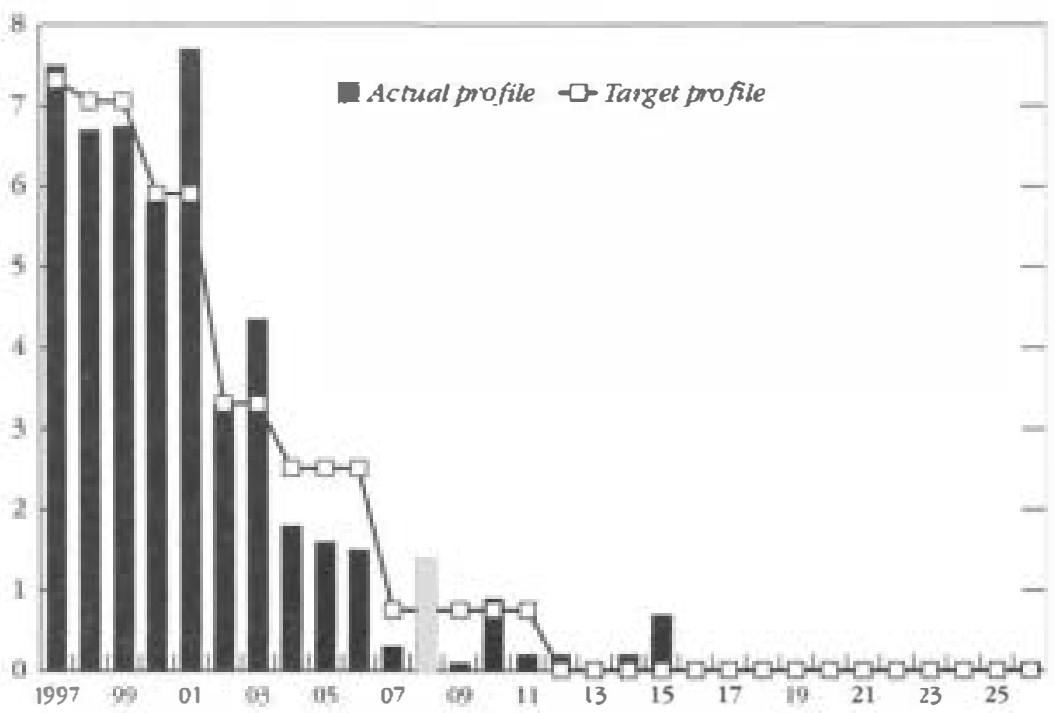

Source: National sources. 
portunities in maturities where the SNDO has higher redemptions than described by the target maturity profile would, therefore, require a lower funding cost in comparison to those maturities where the SNDO still considers there to be room to add further redemptions.

\section{Appendix}

\section{Instruments Used When Managing the Foreign Currency Exposure}

Forward Coniracts

+ Low costs

+ Good liquidity

+ Possible to express views about the short end of the yield curve

+ Easy to manage the short-term foreign currency cashfiows in the portfolio

+ Low credit risks

- Accounting problems (impact on the budget). The underlying exposure (the foreign currency loan) will show unrealized currency gains/losses, whereas the rolling hedge will result in a series of realized currency losses/gains

- A lot of work. Adminisuative and operational risks
Currency Swaps (Basis Swaps)

- Costs could be somewhat higher

- Not as good as forward contracts

- Not possible

- Not possible to manage the shortterm fows

+ Easy to manage the long-term fows

- Much higher credit risks (big impact on credit lines)

+ Much less of a problem

+ Much less of a problem

Instruments Used When Managing the Interest Rate Exposure

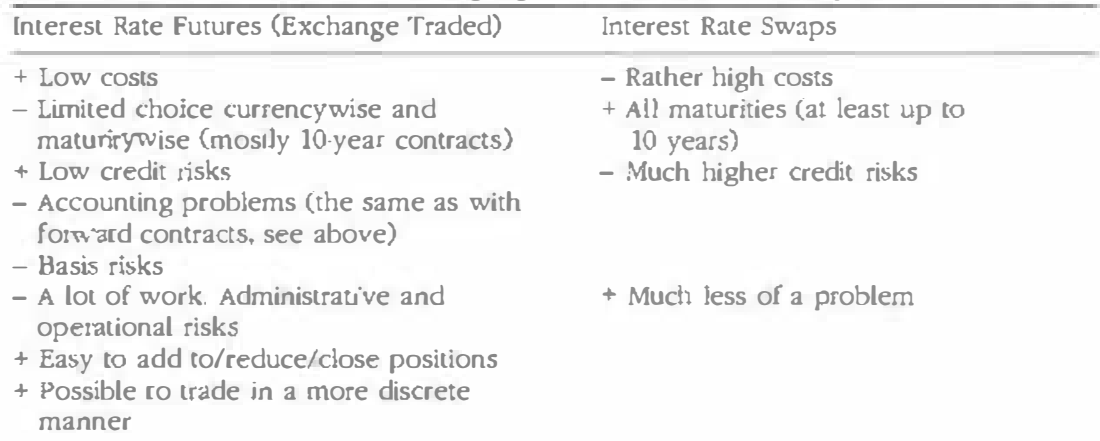




\title{
7
}

\section{Autonomous Sovereign Debt Management Experience}

\author{
Graeme Wheeler
}

$\mathrm{N}$

umerous governance and structures are possible for sovereign debt management agencies. While each has its own strengths, a number of common characteristics run through many of them. This paper discusses the stylized features of well-managed sovereign debt management agencies and comments on New Zealand's experience with sovereign debt management.

Sound sovereign debt management requires the following conditions:

- A management framework that recognizes the public policy and commercial interfaces in sovereign debt management;

- Clear objectives for the sovereign debt management agency;

- A clear separation of the responsibilities and accountabilities for monetary policy and debt management policy;

- A sound strategic framework for debt management policy;

- Well-designed performance measurement and risk management systems; and

- Management information systems integrating the front, middle, and back offices.

Management Framework That Recognizes Public Debt Policy and Commercial Interfaces in Sovereign Debt Management

Regardless of the organizational structure of the debt management agency, the management framework should embody the following features: 
- A clear set of objectives for the organization. Although each organization will have a unique set of borrowing authorities delegated from the government, there needs to be independence from government in the day-to-day management of the debt and liquidity portfolios.

- A clear separation of responsibilities for monetary policy and debt management policy. Without a clean separation, the design of debt management policy is likely to be increasingly influenced by monetary policy objectives rather than sound portfolio theory.

- A well-defined set of accountabilities for the agency's performance. This could be through regular reporting to the Parliament or the Minister of Finance, or to an independent board established by the government.

- A risk management culture that fully reflects the government's risk preferences and the special set of responsibilities associated with representing the government in the financial markets. These responsibilities are considerable. The government's reputation in the financial markets is integrally affected by the interface that the debt office, as its agent, has with the markets. This requires a strong in-house code of ethics for staff as part of a strong risk management culture, and judgment in a range of transacting and relationship management situations.

- Recognition that debt management is also a business that can carry large exposures to market, credit, and operational risks. Debt management requires staff with a combination of portfolio-related expertise and an understanding of the special risk management culture needed for a sovereign transactor. These skills need to be properly rewarded. The chief executive of the debt agency should have authority to appoint staff, and set salary and bonus levels.

- Acceptance that debt management is a business requires budgetary arrangements that recognize that the debt agency can reduce borrowing costs (or enhance returns from investments) and risk for the government. Scrutiny of funding proposals for debt management initiatives, such as spending on information systems, needs to explore the full cost and benefit implications of the investments, rather than simply the expenditures involved. 
Since its inception in 1988, the New Zealand Debt Management Office (NZDMO) has been part of the branch structure of the New Zealand Treasury. This has obvious parallels to a corporate treasury's location and generates the following benefits:

- The NZDMO assists in providing other Treasury outputs. It provides debt-servicing and interest-income calculations that feed into fiscal forecasts. It has direct involvement in the preparation of the government's financial accounts and provides capital market advice on a range of public policy issues and views on monetary conditions and financial market expectations.

- The Treasury can monitor the NZDMO's development and its effectiveness in managing the government's asset and liability portfolios.

While the NZDMO must operate within the strategic parameters approved by the Minister, much of the discretion over day-to-day funding operations has been delegated to the Treasurer. The Treasurer, who is also a Deputy Secretary to the Treasury, is accountable to the Secretary to the Treasury. A three-member Advisory Board, comprising private sector representatives, assists the Secretary to the Treasury to monitor the NZDMO's performance by providing oversight and advice across a broad range of operational and strategic risk management issues and procedural controls. This provides greater transparency in the decision making and supervision process around the NZDMO.

Although substantial progress has been made, the NZDMO is still working to increase its autonomy in respect to setting salary and bonus arrangements.

\section{Clear Objectives for Sovereign Debt Management}

Many countries have announced clear and orthodox objectives for monetary policy. Several countries, including Australia, Canada, Finland, New Zealand, Spain, Sweden, and the United Kingdom have adopted annual inflation targets with an upper band of 3 percent or lower.

However, government objectives for sovereign debt management are often not well specified in terms of cost and risk. In many countries, therefore, debt management policy is undertaken with limited understanding of the govemment's risk preferences and its risk tolerances. Poor performance and diminished managerial accountabil- 
ity within the debt agency, and costly monitoring by the market as it attempts to interpret the agency's policy framework, are inevitable outcomes.

Some agencies have focused on cost, and debt-servicing costs in particular. But this objective is often not well defined in terms of the period under consideration or whether cash-based costs or total portfolio costs marked to market are being targeted. Often the risk framework accompanying the focus on cost savings is not clear.

Prominence has been given to risk considerations rather than minimizing cost in the NZDMO's objective. The NZDMO's objective is:

to identify a low-risk portfolio of net liabilities consistent with the Government's aversion to risk, having regard for the expected costs of reducing risk, and to transact in an efficient manner to achieve and maintain that portfolio.

Three main considerations underlie the government's preference for low risk in its postfolio management:

- Evidence suggests that individuals or, more relevant in a public choice context, "median voters" tend to be risk averse in their decision making, and expect the government to reflect this preference in managing their interests.

- Losses incurred in the government's portfolio impose costs that most taxpayers are unable to avoid. Taxpayers have limited practical scope to foresee and undo the consequences of poor financial decisions by the government. Risk-averse policies reduce the risk of surprises, providing greater certainty for planning.

- The government does not have any competitive advantage over other market participants in attempting to derive excess returns from its portfolio management, except for its privilege as a tax- and regulation-exempt institution and internal information on the fiscal situation or policy objectives. However, the NZDMO does not consider that it is ethical for these exemptions to be exploited.

The NZDMO's objective requires it to consider the expected costs of risk reduction. Minimum risk strategies are not prescribed because additional risk reduction can have high expected costs, making such strategies suboptimal. Information difficulties also mean that it is often not possible to be confident that a portfolio is in its least-risk configuration. 


\section{Separating Debt Management Policy and Monetary Policy}

Separation is critical. Few things undermine the professionalism of debt management operations more than the failure to have a clear separation of responsibilities for monetary policy and debt management policy. Without this clear separation, debt management policy will almost inevitably become subservient to monetary policy as the monetary authorities attempt to use debt management policy as a means of strengthening monetary policy signals and enhancing the credibility of the central bank.

In some situations, debt management policy can support monetary policy, but often issues such as those listed below can create tensions between the central bank and the debt agency. In such circumstances, it is less likely that debt management decisions will be based upon sound portfolio theory. Accordingly, the risk management framework of the debt management agency, and its overall reputation, is compromised. Examples of the potential tensions between monetary policy and debt management policy include: 1

- The central bank may, for instance, argue that the government should issue foreign currency-denominated debt, in the hope that such a move would enhance its own credibility by making it more costly for the government to inflate away the principal value of its obligations, thereby helping to reduce the inflation risk premium in the yield curve.

- The debt management office on the other hand might believe that foreign currency debt increases the overall riskiness of the government's balance sheet if the government's asset pottfolio does not have any significant foreign currency exposure.

- Similarly, the central bank might argue for the issuance of inflation-indexed bonds as a means of enhancing its credibility. This can bring it into conflict with the debt management agency if the agency considers that the market is not ready for such an instrument and that a failed issuance program would reduce the market's view of the professionalism of the debt management office.

'It is assumed that, as in most OECD countries, the central bank is committed to achieving price stability (I shall put aside the issue of def ining this) or low and stable rates of inflation. It is also assumed that the government has not set clear objectives (in terms of cost and risk) for sovereign debt management, or clearly defined policy advisory responsibilities. 
- The central bank may wish to use pricing decisions in daily open market operations to change monetary policy or signal a desired change in monetasy conditions. The debt management office may wish such pricing decisions to be made on commercial grounds only. For example, a daily liquidity management operation involving the purchase of treasury bills to inject liquidity into the banking system might result in bids that are acceptable to the debt office. The central bank may wish to reject them to signal a tightening of monetasy policy.

- Differences in view can also occur in making pricing decisions on inflation-indexed bond tenders. Here, the central bank and the debt office might have differing views about fair value if they have different views on the size of the inflation risk premium and/or the liquidity premium. The central bank may be willing to see tenders underbid (that is, with high real returns relative to conventional bonds) as an indication that few people are concerned about inflation and that inflation expectations are low. The debt oft ice would like lower yields to reduce the government's cost of borrowing.

- The central bank may have a preference for a debt portfolio with a relatively shost duration, as a long duration portfolio may be perceived by the market as increasing the incentive of the government to inflate, thereby weakening the central bank's mandate and credibility. The debt management office may consider that issuance will reduce refinancing risks for the government, stabilize costs, attract new investors, and increase the depth of the bond market.

\section{Experience in New Zealand}

Not surprisingly, in many countries, the relationship between the central bank and the debt management agency can be tense. Fortunately, a good relationship exists between the Reserve Bank of New Zealand (RBNZ) and the NZDMO. Several factors, including considerable dialogue and a clear understanding of roles, have assisted this. Two developments have been particularly important:

- The roles, responsibilities, and accountabilities for the conduct of both monetary policy and debt management policy have been carefully defined. 
- Under the Reserve Bank of New Zealand Act 1989, the implementation of monetary policy, with the objective of maintaining price stability, was identified as the RBNZ's primary role. Price stability is defined in a policy targets agreement between the Minister of Finance and the Governor of the RBNZ as maintaining underlying inflation within a range of $0-2$ percent a year.

Although its responsibilities are not legislated, the NZDMO is responsible for ensuring that the government net debt portfolio is managed consistent with government's risk preferences. Under the Fiscal Responsibility Act 1994, New Zealand governments are required to follow a legislated set of principles of responsible fiscal management and publicly assess their fiscal policies against these principles. Regular reporting requirements are specified to ensure full disclosure of the government's fiscal position.

Agency agreements between the NZDMO and the RBNZ clarify the principal/agent role in those areas where the RBNZ provides services for the NZDMO. The RBNZ acts as the NZDMO's issuing agent, registrar, and paying agent in the domestic market, and conducts daily liquidity management operations and treasury bill and bond tenders on the NZDMO's behalf. An important provision in the agency agreement on cash and wholesale debt management is that all functions carried out by the RBNZ as agent for the NZDMO are conducted without reference to monetary policy considerations.

This agreement also makes clear that the NZDMO is responsible for making all pricing decisions on treasury bills and government bonds, and for advising the Minister of Finance on the size and structure of the domestic borrowing program, which is announced on budget day.

Both the RBNZ and the NZDMO are committed to the principles of transparency, neutrality, and evenhandedness in conducting their business. (The application of these concepts to the NZDMO's domestic debt management is discussed later in this chapter.) Implementing a clearly defined policy framework in a consistent manner reduces monitoring costs by investors and assists their decision making.

\section{Establishing a Sound Strategic Framework for Sovereign Debt Management}

As with several other sovereign debt agencies, the NZDMO used mean-variance modeling to help it find a low-risk portfolio for the

\section{CInternational Monetary Fund. Not for Redistribution}


government's foreign currency debt. This modeling used a one-year duration New Zealand dollar liability as a low-risk benchmark to determine the riskiness of alternative portfolio structures. While this technique provided useful information on currency composition, the NZDMO was uncomfortable with the modeling work with respect to interest rate risk for two main reasons:

- Portfolio compositions suggested by the modeling were unstable, depending upon the period under review. Successive New Zealand governments had embarked on comprehensive structural reform, which also generated large movements in interest rates and the exchange rate. This limited the predictive power of the modeling.

- Questions arose as to whether the benchmark was appropriate given that there was only limited information available at the time on the asset side of the government's balance sheet.

\section{Balance Sheet Approach}

This situation began to change in the early 1990s. Information increasingly became available on the structure of the government's assets. Accrual-based accounting systems were replacing cash accounting systems in government agencies. From December 1991, on a six-month basis, the government was required to produce consolidated financial statements based on generally accepted accounting practices. This opened the way to the possibility that the government's risk might be reduced by matching the risk characteristics of the government's liabilities with those of its assets. If such matching were possible, liability structures would provide natural hedges against shocks to the government's balance sheet, reducing the effect on the government's net worth.

With this principle in mind, in 1993, the NZDMO commissioned three leading North American specialists in duration theory to quantify as far as possible the risk characteristics of the assets in the government's balance sheet. The objective was to gain better insight into the government's overall balance sheet risk and to develop a stronger conceptual framework for strategic debt management. This framework would explore whether it was feasible to match the structure of the government's assets with its liability portfolio in order to dampen the impact of interest rate and currency move- 
ments on the government's net worth. Sizable challenges needed to be confronted, particularly given that many of the government's balance sheet assets were physical assets in the nature of public goods, which did not generate cash flows.

The consultants were asked to derive a methodology for calculating the risk characteristics (real duration and sensitivity to exchange rate movements) of the three largest real assets in the government's balance sheet: highways, equity in the governmentowned electricity system, and land and buildings. Duration of the physical assets was based on calculations of the cash flows or benefits guaranteed by the assets, the discount rate, and the remaining asset life. Asset duration is able to be calculated if the cash flow or benefits are assumed to be the same in each fiuture period, and the discount rate and maturity of the asset are known. A benefit of this approach was that it was not necessary to specify the absolute level of benefits flowing from the assets. It was sufficient to forecast the likely growth rate of benefits. To estimate the duration of the national highway system, for example, technical data were gathered on the economic life of the asset. Scenarios were developed based on different growth rates in services and the real discount rate. These scenarios were combined to produce an overall weighted duration of about 15 years. It was decided, however, not to complete the work for a range of reasons:

- The poor quality of the data on the government's assets resulted in large standard errors around the estimates of the interest rate sensitivity of the assets.

- There was insufficient information on the extent to which the assets were nominal or real in nature. This is important because changes in nominal interest rates caused by changes in inflation expectations will change the value of nominal assets but not real assets.

- There were concerns about the legitimacy of the assumption used that cash flows or benefit streams were insensitive to interest rate changes. While this assumption made the estimation problem more tractable, it was difficult to know how strong an assumption this was.

Nevertheless, some important conclusions did emerge from this work:

- The duration of the assets tended to be quite long. implying that the debt portfolio should also have a long duration. 
- Some of the government's assets were real assets (generating cash flows indexed to movements in inflation), the value of which was sensitive to changes in real interest rates, implying there was a strong case for issuing real, or inflation-indexed, debt.

- The asset prices were not significantly sensitive to exchange rate movements, implying that holding foreign currency debt in the government's debt portfolio introduced significant variability to the government's net worth.

This study suggested that the NZDMO should reconfigure its debt portfolio over time to remove foreign currency exposures and achieve a longer duration of New Zealand-dollar debt, including inflation-indexed securities.

\section{Foreign Currency Debt Management}

These developments came later. In the meantime, the government was gradually paying down its net foreign currency debt (which totalled \$NZ15 billion at June 1991) by using the cash proceeds from state asset sales, and some additional domestic borrowing. However, a large stock of foreign currency debt remained to be managed. The strategic benchmark for managing the foreign currency debt portfolio drew insights from the mean-variance modeling and an efficient market approach of "selling the market." This approach reflected the NZDMO's view that it was unable to systematically predict the cheapest forms of borrowing and that diversifying its foreign currency exposures acress currency blocs was a low-risk portfolio management appreach.

The NZDMO's mean-variance analysis had consistently shown that the U.S. dollar represented the dominant currency (from an NZ dollar base) when attempting to reduce risk. However, the mix between Japanese yen and European currencies was unstable and the NZDMO was unwilling to contemplate the large rebalancing costs that would result from a strategy that called for strict adherence to the output of the model. In addition, as the input to the model included a historic variance/covariance matrix, there was an assumption that these relationships would hold in the future.

Given these factors, a portfolio was constructed where the net liability centered around 50 percent in U.S. dollars, 25 percent in yen, 
and 25 percent in European currencies. However, the benchmark was allowed to fluctuate by 5 percentage points on either side of these levels, reflecting the approximations in the process. It is difficult to argue conclusively that a portfolio with 46 percent in dollars is more risky than one with 50 percent in dollars. A second reason for the $50 / 25 / 25$ percentage split was that these ratios corresponded approximately to relative GDP weights of the currency blocs and were therefore consistent with a "sell the market" strategy.

As noted earlier, mean-variance analysis provided little useful information on interest rate risk in the portfolio. A low-risk portfolio tended to reflect the horizon period of the analysis. Given that the foreign currency liabilities were not funding identifiable assets, the NZDMO was in a similar situation to a mutual fund or unit trust manager with an asset portfolio that is not funding a specific liability. A valid, risk-averse strategy is to "buy the market" to diversify risk. Therefore, the NZDMO adopted the duration of the government bond market in each currency as the target duration for that currency portfolio. This strategy meant that the NZDMO tended to issue into the most liquid segments of the relevant markets.

All refinancing transactions were required to maintain the currency composition of the portfolio within its bands and move its duration closer to the duration of the government bond market for that currency bloc. This meant that, over time, the foreign currency portfolio would move closer to the strategic benchmark portfolio.

\section{Debt Reduction}

In 1994, the New Zealand government achieved a fiscal surplus. With the Treasury's economic projections suggesting sizable fiscal surpluses for the foreseeable future, the government set an objective of reducing its net public debt-to-GDP ratio as rapidly as possible from 43 percent of GDP in June 1994 to below 30 percent of GDP, followed by a more gradual reduction to below 20 percent of GDP.

Several reasons lay behind the government's decision to reduce its indebtedness. Important among them has been a desire to:

- Reduce the economy's vulnerability to economic and financial market shocks.

- Reduce debt-servicing obligations. 
- Lower the risk premium in the term structure of interest rates, reducing the cost of capital to all firms in the economy.

- Increase the government's and the country's creditworthiness, with the subsequent rating implications also feeding through into interest rates.

- Provide the government with a buffer against the future spending implications of an aging population.

- Provide greater scope for reducing the variability of future tax rates, and therefore reduce the deadweight losses associated with this.

- Provide greater certainty for individuals with regard to their investment and consumption decisions.

Within the overall debt objective, the government gave priority to reducing its foreign currency debt exposure. In mid-1994, when the government's net foreign currency debt totaled $\$ N Z 10.2$ billion, an objective of obtaining zero net foreign currency debt in three years' time was set. This objective was achieved in September 1996, and financed by a combination of cash receipts from the government's operating or fiscal surplus, the sale of state-owned assets, and some additional borrowing in the domestic market. By June 1996, net public debt had declined to 32 percent of GDP. Repaying foreign currency debt rather than domestic debt was desired because:

- The NZDMO's research indicated that the value of the government's assets were much more sensitive to movements in domestic interest rates than to movements in the exchange rate.

- Exchange rate risk cannot be hedged cost-effectively given the magnitude of the external debt portfolio and the capacity of the New Zealand dollar foreign exchange market.

- Rating agencies are concerned about external debt levels, particularly in relation to total export earnings.

- Repatriation of foreign currency debt helped to develop the diversification and liquidity of the New Zealand domestic bond market.

Extensive modeling work was undertaken in an attempt to find a low-risk approach to paying down the government's net foreign currency debt. In particular, the NZDMO was concerned to find a cost-effective profile for the reduction of net foreign currency debt, which had little foreign currency and interest rate risk for the government. Currency and interest rate risks arose because the government's projected cash flows (from fiscal surpluses and privatization 
receipts) were in New Zealand dollars, and its repayment obligations fell in various maturities across various foreign currencies. A low-risk approach required the government to progressively eliminate the debt in the currencies that were least correlated with the New Zealand dollar and to hedge the long-dated interest rate exposures before hedging the short-dated liabilities.

Paydown of the government's net foreign currency debt was achieved by using available cash to retire maturing debt, acquire hedges in the form of cash flow matching swaps, and repurchase some long-dated Yankee and Bulldog debt. Repurchasing debt was desirable because it reduced the size of the government's balance sheet, reducing both credit risk (of the offsetting hedges) and the ongoing need to manage the debt.

\section{Domestic Debt Management}

With the objective being to reduce net public debt levels, it was no longer appropriate to increase the duration of the domestic debt portfolio in the manner that the asset and liability study implied. Instead, the NZDMO manages the composition of the domestic debt portfolio so as to diversify risk, reduce cost, and meet a range of public policy objectives. Refinancing and interest rate risk is reduced by ensuring that the maturity profile is relatively smooth and issuance is spread across the term structure. The longest nominal benchmark bond has a 10-year maturity. Inflation-adjusted bonds. which have recently been introduced. have a 20 -year maturity. '?rice (rate) risk is diversif ied by sampling interest rates over the fiscal year and issuing a mix (approximately 3:1) of fixed and floating rate debt.

In its debt management, the NZDMO is strongly committed to the principles of transparency, neutrality, and evenhandedness. It believes that adherence to these principles will lower the government's borrowing costs by reducing price unceltainty and encouraging competitive bidding, and that these gains should outweigh any short-term gains available through opportunistic borrowing in the domestic market.

Transparency surrounding the government's domestic borrowing intentions is enhanced by publishing the auction calendar for the forthcoming year with the budget. The details provided include the 
overall size of the annual borrowing requirement, and the dates and the size of the auctions. Auction predictability allows market participants to plan with confidence, and helps the market absorb sizable amounts of government securities. It has also helped encourage substantial foreign portfolio investment. As of September 1996, foreigners held 53 percent of the government securities in the market.

Neutrality and evenhandedness are promoted through the auction process. Conventional bonds and bills are sold through a multiple price auction system. Inflation-indexed bonds are sold through a uniform price auction to reduce the potential "winners' curse" problem, which is accentuated with the introduction of a new security. ${ }^{2}$

\section{Well-Designed Performance Measurement and Risk Management Systems}

Performance measurement needs to be applied to both tactical and strategic trades, and measures need to be developed with respect to cost and risk objectives. Well-designed performance measurement systems are critical because they provide:

- Management information regarding the magnitude and nature of discretionary decisions to assist them in thinking on alternative financing or investment strategies.

- Portfolio managers with information to assist them in managing the controllable risks for which they are responsible and provide feedback on the quality of their decisions.

- Information necessary to generate incentive structures that ensure staff incentives are aligned with those of the debt agency.

Sound risk management policies are needed for managing market risk, funding risk, liquidity risk, settlement risk, credit risk, and operational risk. For the sovereign debt management agency, the management of liquidity risk and credit risk is particularly important. Risk-averse sovereigns with well-designed strategic frameworks and sound tactical trading policies are unlikely to be exposed to substantial market risk in terms of position taking. A government's rep-

2Under a uniform price auction, all successfiul bidders pay the lowest successfial bid. In a discriminatory price auction, the successful bidders pay their own bids. As a result, a high bid not only increases the probability of being successful, but also increases the probability of reduced profit or subsequent loss for that bidder. This auction pricing technique could induce a significant risk premium into bidding when a new instrument is difficult to price. 
utation would, however, be seriously damaged if it defaulted as a result of a poorly designed liquidity policy, or if it incurred substantial costs through inappropriate credit policies for its liquid assets and swaps portfolios.

\section{Performance Measurement and Risk Management in the NZDMO}

Performance measurement within the NZDMO is currently based around cost rather than risk considerations. When the government had a large amount of net foreign currency debt, the actual portfolio was closely monitored to ensure that it was moving toward the lowrisk strategic benchmarks (based on the currency mix and interest rate sensitivities described earlier). Currently, the government's foreign currency debt and asset portfolios are fully immunized so that there is no currency or interest rate risk around the government's gross foreign currency debt portfolio. Cost performance is measured on two types of NZDMO transactions:

- Liquidity management or investment transactions. The NZDMO is required to manage a considerable amount of foreign currency liquidity to meet upcoming principal repayments or debtservicing payments on floating rate swaps used to hedge the fixed rate foreign currency debt.

- Foreign exchange purchases, when the NZDMO funds debtservicing payments out of domestic currency.

In each case, a shadow or benchmark portfolio has been established and value added is defined as the difference in value between the actual and the shadow portfolio. None of the value added is risk-adjusted at this stage.

Rules were established for the shadow foreign currency transactions. Portfolio managers have discretion to lead or lag the shadow portfolio trades. The benchmark portfolio for the liquidity book (foreign currency investments) is based on prescribed asset allocations and expected returns on the assets. The liquidity manager is free to vary the asset allocation within limits, and expected returns are adjusted regularly. Tactical trading within conservative limits is also undertaken and the performance of such trades is measured daily. 
Credit risk arising from the management of the portfolio is carefully managed.

- Since 1988, the NZDMO has consolidated credit risk reporting across all financial instruments, including assets and offbalance-sheet exposures arising from foreign exchange transactions and swaps. Credit limits are based on a time-weighted combination of marked-to-market exposures plus a margin for market volatility. The time weighting increases the amount of credit limit utilized as the maturity of the transaction increases

- All credit exposures are monitored daily, and situations where credit quality falls below a minimum threshold are addressed immediately.

- A Credit Support Annex has been appended to the NZDMO's swap documentation to cap the exposure to individual counterparties. It outlines arrangements for the posting of collateral once exposures reach specif ied levels. Credit support, through the posting of collateral, is one way for those institutions rated below New Zealand's sovereign rating by either of the two major rating agencies. It is also unilateral if New Zealand is assigned a triple-A foreign currency rating by both rating agencies.

- The NZDMO is developing a credit pricing model to ration scarce credit limits, based on the value added from incurring credit risk. Up until now, the NZDMO has used rules of thumb to price credit risk on structured transactions.

\section{Management Systems That Integrate the Front, Middle, and Back Office}

There is a rapidly growing global demand for front, middle, and back office technology with user-f riendly functionality. Such growth has been stimulated by the well-published risk management failures in major corporate and financial intermediaries over the past five years, the development of G.A.R.P. (generally accepted risk management principles), and the value-at-risk methodology and database. Risk management software suppliers are competing to provide integrated front, middle, and back office systems based on open databases. Others, specializing in middle office risk management 
systern.s, are seeking to develop their products to include measurement of credit risk as well as market risk.

A sovereign debt agency is faced with several difficult challenges:

- Defining its current and future user needs in the light of future business process reengineering possibilities.

- Deciding whether to develop an in-house, highly customized management information system or whether to purchase an "off-the-shelf" standard risk management system and undertake additional customization.

- Deciding which standardized risk management system to purchase.

- Ensuring that the project is well managed, runs to budget, and is completed on schedule and that the product is widely accepted within the organization and staff are trained fully in its functionality.

\section{NZDMO's Experience}

The NZDMO developed its current management information system in-house over a nine-year period (work commenced before the NZDMO was established). It was primarily a middle and back office system with deal-capture facilities. It provided the NZDMO with daily mark-to-market valuations for the portfolio.

Over time, several problems began to emerge $w^{-i t h}$ this system, including the fact that the hardware platform became outdated, the database was closed, and the system was unable to interface easily with new work applications. A range of spreadsheet applications was developed to provide information unable to be produced by the existing management information system.

In addition, the NZDMO faced substantial key person risk in developing its information systems. After sending out requests for proposals to 26 systems vendors and completing considerable in-house testing, the NZDMO purchased the Infinity Derivatives System in December 1995 . The NZDMO is the only Infinity client currently attempting to introduce the integrated front-to-back of fice Int inity system across the full range of financial instruments in which it deais.

Deal capture has been completed for all existing transactions, and the front office system has been introduced to the portfolio managers and cash managers, in parallel with the existing system. Im- 
plementation of the complete system was completed by December 1997. Key benefits from the system include:

- The new system will run on a state-of-the-art technology platform.

- The new system will provide greater flexibility for users owing to the open database and the ease of interfacing with other work applications.

- New modules can be added on as they are developed by Infinity or other third parties.

- The operating costs should be lower with the new system.

- The risks of "key person" dependency are reduced.

A number of key management insights have emerged on the project:

- Installation is almost invariably more complex than early specification suggests.

- Developing a well-skilled project team with knowledge of the software and the NZDMO's operations can take considerable time.

- There is an ongoing need to undertake business process reengineering reviews to improve efficiencies and maximize the use of the system.

- It is important to build the information technology skill levels throughout the organization so that all staff recognize and can access the benefits of the new software.

- It is also important to manage expectations of the project. Because it was custom-built, the existing management information system meets many of the users' needs, whereas the new system cannot deliver all that users want without significant customization.

- Maintaining good communication and relationships with Infinity and other possibie software suppliers is important in order to influence software development in line with the NZDMO's requirements.

\section{Conclusions}

Establishing competencies in the stylized features of sovereign debt management identified in this paper involves substantial management challenges. Sovereign debt management is not a simple, 
straightforward operation. It is a complex and specialized business that requires expert portfolio and risk management skills and a sound understanding of public policy objectives.

Looking ahead at the NZDMO's work program, several strategic issues will continue to be explored in managing the government's net debt. These include the optimal level and structure of the domestic debt portfolio and the role of foreign currency reserves and foreign currency debt in the government's balance sheet. Key operational issues are the continued implementation of flexible and integrated information systems and the ongoing development of riskadjusted performance measures. While these are challenging and complex issues, the degree of complexity is reduced markedly by having established clear strategic and operational objectives for the government's debt management. 


\section{Public Debt Management Strategy: Belgium's Experience}

\section{Louis de Montpellier}

Tn recent years, the Belgian Treasury has devoted much time and resources to define the most adequate structure for its public debt portfolio. In mid-1995, the Treasury decided to develop a methodology to establish the debt portfolio structure that best minimizes the financial cost of the public debt with acceptable risk levels, taking into account the general objectives of budgetary and monetary policies. Based on this methodology, the Treasury has been designing a benchmark debt portfolio, which it was intending to use as a reference for the strategic management of public debt from 1997 onward.

\section{Trends in Belgian Public Indebtedness}

The development of the benchmark is the last step of several fundamental reforms in public debt management undertaken since the beginning of the 1990s under the leadership of the Minister of Finance, Philippe Maystadt. These reforms were especially cricial given the high public indebtedness of Belgium, whose causes 1 will briefly mention.

The Belgian public sector has traditionally experienced a rather high level of indebtedness in contrast with the private sector. In this respect, Belgium differs from other European countries like Denmark or the United Kingdom, which have known the reverse situation. At the end of the 1960 s, Belgian public debt as a percentage 
of GDP was already twice the European average. The accumulation of budget deficits during the 1970s following the energy shocks exacerbated this trend. In 1981, the Belgian public deficit stood at 13.5 percent of GDP, debt-cost service was close to 8 percent, and total debt was 82 percent.

The cost of debt service had by then reached a level generating a "snowball effect" - an automatic increase due to financing the cost of existing debt. This effect, combined with lower economic growth and infation and higher interest rates in the 1980s, brought the public debt to a level of 130 percent of GDP at the end of 1987, where it stabilized following a first period of public sector austerity from 1982 to 1987. The deficit was thus brought back to a level of 6.8 percent of GDP in 1987. The economic recession at the beginning of the 1990s then threatened to inflate deficits and debt once again (to 7.1 percent and 135.2 percent of GDP, respectively, in 1993), prompting the present government to take a drastic new set of austerity measures in 1994 and 1995. Between 1993 and 1997, considerable progress was made in putting the public deficit and the government debt ratio on a clear downward trend. The deficit declined by 5 points of GDP, to 2.1 percent at the end of 1997; the debt ratio declined by 13 points of GDP, to 122.2 percent of GDP in 1997, and the primary surplus (i.e., the budget deficit with the exclusion of interest payments on public debt) rose to 5.8 percent of GDP. The level of primaly surplus that the authorities have committed to maintain for years to come in Belgium's New Convergence Program (as approved by the Belgian government in December 1996 and endorsed by the European Council of Finance Ministers in Februaly 1997) is sufficiently high as to guarantee that the debt reduction process will continue, even if economic growth slows down.

Foreign debt increased in the late 1970s and the early 1980s owing to continuing deficits in the balance of payments and the budget. The National Bank often needed to replenish the stock of its reserves during several periods of Belgian franc weakness, and the Treasury met these needs by issuing foreign debt. As a proportion of total debt, foreign debt grew from 1 percent in 1978 to 24 percent in 1984. As a result of the efforts to stem the budget deficits at the beginning of the 1980s, the return of surpluses in the balance of payments, and the formal peg of the franc to the strongest currencies of the European Monetary System (EMS), particularly the deutsche mark, the proportion of foreign debt decreased regularly 
between 1985 and 1992 to reach 12 percent of total debt. During the EMS crisis of 1993, intervention in the foreign exchange market by the National Bank was partially financed by borrowing abroad. The foreign debt proportion edged back up to 17 percent in 1993. At the end of 1997, it was brought back to 7.5 percent of the total debt. It is expected to decrease further in years to come, especially following the introduction of the euro.

Since about 1980, Belgium has been pursuing a tight budgetary policy and a stable, anti-inflationary monetary policy, reversing the trend of the two previous decades. These policies have been mainly motivated by the need to prevent an unsustainable public debt accumulation, which would have prevented the country from meeting three fundamental challenges: an aging population and growing pension liabilities; the recovery of budgetary freedom to meet new or recurring public sector or social needs; and accession to the European Monetary Union. The establishment of economic policies necessary to meet these challenges has completely redefined the macroeconomic context in which public debt is managed.

\section{Market Reforms at the Beginning of the 1990s}

At the beginning of the 1990s, a fundamental reform of the Belgian capital markets was undertaken. New, dematerialized instruments were introduced in the money market (short-term treasury certificates at 3,6, and 12 months) and in the capital market (linear bonds, or OLOs, with maturities ranging from 1 to 20 years). The former banking consortium was abolished and competitive auction systems were introduced.

From the point of view of debt management, the main effect of these reforms was to significantly reduce the financial cost of the debt, while allowing for a diversification and a lengthening of maturities in the debt portfolio. From a broader macroeconomic perspective, these reforms improved the efficiency of monetary policy (through opening up more opportunities for open-market operations), established a clear dividing line between monetary and budgetary policies, and allowed for more controlled management of the budget. The reforms also substantially improved the general context of savings and investment in Belgium, benefiting economic activity as a whole. 
At the same time, the authorities embarked upon a structural adjustment of the public debt portfolio to reduce the budget's vulnerability to financial evolution. They started, for instance, to lengthen the debt maturity spectrum, and reduced (whenever possible) the proportion of foreign debt. To refine this broad debt portfolio strategy, the Treasury decided to develop a benchmark debt portfolio.

\section{Defining a Public Debt Management Strategy}

In embarking upon such a thorough strategic exercise, it is crucial at first to define clearly the objective-and the risks involvedin the exercise of public debt management. Second, the question arises as to whether public debt management should be approached as an asset/liability management or a portfolio management problem. Third, the public debt manager should have a clear view about the macroeconomic context he or she is operating in, and the constraints that context imposes. All these elements have institutional implications, and a clear understanding of these objectives and constraints should assist in the establishment of an efficient institutional framework. However, the historical development specific to any country should never be underestimated when institutional frameworks are discussed.

\section{Objective and Risks}

According to Belgian legislation (in the budget law), the objective of public debt management is "to minimize the financial cost of the public debt, while maintaining market and operational risks at an acceptable level, taking into account the general objectives of the budgetary and monetary policies."

Several aspects of this definition should be emphasized. First, the objective of the Belgian Administration is to minimize the financial, long-term cost of the debt, and not only the current budgetary cost. A financial, long-term cost measure of the public debt should adequately capture the cost of debt servicing on all future budgets.

Second, it is crucial to define the precise nature of the risks run by the sovereign debt manager. It is useful to distinguish two types of risks. As for any market participant, the manager of the public debt is subject to financial risks, such as market-price risks, credit risks, and operational risks. However, the manager of the public 
debt is also subject to risks-specific to the funding of a sovereign state-which could be qualified as "macroeconomic" risks. These include the risk that public debt management could run contrary to or endanger some economic policy objectives of the government.

As an example, take the case of an extremely steep yield curve, such as where the difference between six-month and 10-year rates is 300 basis points. In such an environment, the sovereign debt manager could be tempted, even in a conservative financial risk management framework, to maintain a sizable proportion of the debt in floating rate forms in order to save costs for taxpayers. However, when the sovereign is running a high debt-to-GDP ratio and is following a stable exchange rate policy, as is the case with Belgium, the proportion of floating rate debt should be limited-to leave full freedom to the central bank to raise short-term rates rapidly in order to defend the parity of the currency in the case of a speculative attack-without endangering the current budgetary objective of the government. If the interactions between sovereign debt management, monetary, and budgetary policies are not fully understood, quantified, and integrated into the public management framework, then public management may run into conflicting objectives and disaster may unfold.

\section{Asset/Liability Management Aspects}

It may be interesting to consider public debt management in an asset/liability management context, but it should soon become apparent that this approach does not provide a clear-cut guide for managing the public debt portfolio. The basic reason is that the cash flows on the asset side of the balance sheet of the state are not of a financial nature and therefore do not demonstrate a comparable sensitivity to financial variables (such as currencies and interest rates) as does the debt side of the balance sheet. Put otherwise, the financial "zero-risk position" of the state cannot be calculated, in contrast with a financial intermediary.

However, an asset/liability approach can provide the public debt manager with some valuable insight. The asset side consists mainly of internal revenues taking the form of fiscal cash flows, at least in the case of a diversified market economy. External revenues are commercial surpluses, which, when accumulated into currency reserves, provide foreign currency cash flows. This approach offers 
several insights. As the state's revenues are overwhelmingly denominated in domestic currency, the public debt manager should favor domestic debt. However, he or she should also consider matching the level of foreign clebt (if any) with foreign exchange reserves. Finally, as the duration of the state's assets are rather long, the public debt manager should favor long-term fixed rate clebt.

\section{Portfolio Management Aspects}

These considerations, however, are clearly insufficient to build a thorough public debt management strategy. The public debt matnager should therefore resort to a portfolio management approach, where one attempts to minimize cost under the constraint of maintaining risk at an acceptable level. The public debt manager is therefore in a position comparable to that of a fund manager. who has to assess the risk aversion-or appetite-of clients.

Often. fund managers try to embody this risk aversion into some kind of market index. which becomes their portfolio benchmark. This is what the Belgian Treasury has attempted to achieve in setting up its own debt benchmark portfolio. Indeed. the public debt manager should assess the risk aversion of the government and of the taxpayer, not only with regard to financial risks. but also with regard to macroeconomic risks. It is straightforward that his or her attitude should be conservative toward financial risks. But it should also be clear that the public and governments aversion with regard to macroconomic risks should he even greater than with financial risks-so that these macroeconomic risks are stringent constraints that strictly confine the financial management universe of the puhlic debt manager.

\section{Policy Constraints}

Two types of economic policies impose constraints of a macroeconomic nature on public debt management: monetary policy and budgetasy policy.

\section{Monetary Policy}

In the case of Belgium, the monetary policy of closely pegging the exchange rate of the Belgian franc to the strongest currencies of

\section{(C) International Monetary Fund. Not for Redistribution}


the EMS (and in particular to the deutsche mark) directs debt management in two respects: with regard to the proportion and composition of foreign debt, and with regard to the proportion of floating rate debt within domestic debt.

First, a monetary policy aiming at stable exchange rates influences the proportion and the composition of foreign debt-as such a policy necessitates a sufficient level of foreign exchange reserves and smooth access to international money and capital markets. The surest way to meet these constraints is to maintain a certain level of debt in the markets for reserve currencies. However, the proportion of foreign debt should not be too high, as it should be flexible enough to allow for a rapid increase in case of intervention needs, without unbalancing the whole public debt portfolio.

In addition, two economic factors have also recently induced the Belgian Treasury to gradually reduce the proportion of foreign debt within the state's total debt. On the one hand, the state has been accumulating reserves for several years in the form of sizable balance of payments surpluses; this structural trend seems set to remain. And when Belgium is within the new European Monetary Union, the management of international reserves for intervention purposes will become less of a priority - at least for the state itself. Taking these considerations into account, it is unlikely that the actual proportion of foreign debt will increase in the years to come.

Second, as we have seen, a monetary policy aiming at stable exchange rates limits the proportion of domestic floating rate debtin order to leave the central bank the greatest possible flexibility to influence short-term rates through open-market operations. This objective is difficult to quantify. But it is also in order to meet this constraint, as well as to improve budgetary control, that the Treasury progressively reduced the proportion of domestic floating rate debt from 36 percent at the end of 1990 to 21 percent at the end of 1997. Recent experience seems to demonstrate that a proportion of floating rate debt around this level is satisfactory from both budgetary and monetary perspectives.

\section{Budgetary Policy}

Two specific objectives of the state's recent budgetary policy have been major determinants of debt management: the annual budgetary objective limiting the public deficit as a set percentage of 
GDP (such as 1.7 percent projected for 1998) and the annual reduction of government debt as a percentage of GDP. The first objective imposes constraints on the average duration of the debt portfolio, on the fixed/floating ratio, and on the amount of annual refunding. The second objective imposes a constraint on the volatility of the Belgian franc value of the total debt.

First, the government's budgetary objective dictates a Belgian franc maximum amount per year devoted to servicing the debt. It is intuitively clear that the shorter the average duration of the debt poitfolio, the larger the refunding amounts due within the year, and consequently the greater the volatility of the annual budgetary cost. Therefore, the budgetary objective imposes a minimum average duration on debt management. Furthermore, the budgetary objective is more likely to be met if the proportion of floating rate debt is not too large. Finally, the budgetary constraint will apply in any future year. It is therefore crucial to ensure a "smooth profile" to the debt repayment schedule until maturity.

Second, the objective to create the "virtuous snow-melting effect" of a gradually decreasing debt-to-GDP ratio will be ensured over the years by the combination of a continuous primary budget surplus (targeted at about 6 percent over the next several years) and normal economic growth (forecasted at 4.5 percent nominal, or 2 percent in real terms on average over the next several years), resulting in diminishing interest charges on the debt and a shrinking public deficit.

Although this objective is not quantified in ternss of GDP percentage points, it is clear that it imposes a constraint on the volatility of the total value of the debt stock expressed in Belgian francs. Therefore, this constraint aims at limiting the proportion of foreign debt and at favoring foreign debt in currencies, which have historically experienced low volatility against the Belgian franc.

\section{Institutional Implications}

A clear conceptual framework defining the objective of public debt management, the costs and risks inherent to it, and organizing the interaction between sovereign debt management and monetary and budgetary policies is crucial to the adequate conduct of debt management policy. A correct conceptual framework should clarify 
respective tasks and responsibilities; the precise institutional arrangements then become secondary, though some are clearly more conducive to optimal public management than others. The most obvious example, now adopted in many countries of the industrialized world, is the independence granted to the central bank to conduct monetary policy.

In Belgium, public debt management is run by the Treasury as an independent function within the administration, separated from the other functions of economic policies (mainly the budgetary, or fiscal and monetary functions). The strategic review that was designed to establish a benchmark portfolio as a reference for the management of public debt (starting from 1997) also helped to clarify some aspects of the institutional framework. A more straightforward definition of the objectives and risks of public debt management was also integrated into the annual budget law, as well as an explicit reference to the context of monetary and budgetary policies in which this management has to take place. The law makes reference to annual general guidelines, to be established by the Minister of Finance on the basis of a proposal of the Treasury, concerning the management of public debt during the budget period. The Treasury is thus expected to optimize financial management of the public debt, with reference to the benchmark debt portfolio, as prescribed by the general guidelines. This transparent framework should strengthen risk management and performance assessment. It should also prevent decisions and operations pertaining to public debt management to convey signals about macroeconomic policies, and therefore improve the transparency and efficiency of the domestic financial market.

Note: This contribution ulas uritten at the time of the conference in November 1996. Revieuring it in early 1998, the Belgian Treasury confirmed that all strategic, managerial, and institutional changes mentioned urere currently being carried out at the foreseen pace. 


\title{
Central Bank Reserves Management
}

\author{
John Nugée
}

This paper opens discussion of the second part of the subject 1 matter of the conference, namely asset management for sovereigns. Previous papers have concentrated on liability management, and have neces.sarily, given the authors of those papers, done so in isolation of any consideration of asset management issues. However, there is a real sense in which asset management is the more common, and more basic, half of the subject matter of the conference. Not all countries either need to borrow, or are able to access capital markets even if they wish to. But all countries without exception have foreign currency reserves, even if only in limited amounts.

\section{Management of National Foreign Exchange Reserves}

The management of national foreign exchange reserves is therefore a key duty of the authorities in almost all countries. Indeed, this is true for all countries with perhaps the single exception of the United States, where, as the country with the world's reserve currency, it may be less important. However, even for the United States, the reserves are a nonnegligible policy item.

The administrative arrangements for the ownership of reserves is not identical across all countries. In some countries, they are formally on the balance sheet of the central bank, while in others, they remain with the central government more directly. However, the duty of managing the reserves is nearly everywhere entrusted to the 
central bank. Central banks in various countries face varying situations, both economic-in terms of their country and their country's economy-and structural, in the way the central bank fits into the government framework and the way it responds and reports to the central government.

Some of the challenges facing those central banks are also different. For example, the United Kingdom has oscillated between being in a fixed exchange rate system and a floating exchange rate system. In Japan's case, the problem is that of a currency that has at various times in history been sent far too high by the international markets for the authorities' comfort. Other countries have nonconvertible currencies, multiple exchange rates, and so on.

Given these different circumstances facing central banks, one might expect that this would lead to different responses, and great variances not just in the way reserves are managed, but in the fundamental objectives that reserves managers wish to pursue. In fact, this is not generally the case. There are strong common features and common factors between the reserves management operations of nearly all central banks, and a high degree of agreement about the proper objectives for official reserves management. This paper is being presented to a number of central banks and a number of reserves management operations. We do all face different circumstances, but the response that centsal bank reserves management managers will formulate to those challenges will tend to be similar.

There are three main reasons why official reserves management operations share a relatively common structure. The first common feature is that the assets under management are public assets. Central bank reserves managers are trustees for the public, and will therefore have a fiduciary responsibility to the ultimate owners to preserve those assets. This leads to a high premium being placed on security. Security is important for central bank reserves managers, and this is true whether or not the assets are actually on the central bank's own balance sheet. It does not make any difference whether they are on the central bank's balance sheet or on the Finance Ministry's balance sheet. Wherever they are, they are public assets, and this imposes a fiduciary duty on the central bank.

The second common feature is that, in most cases, the assets are there to be used. Few central banks hold assets for their own sake, as some form of investment portfolio. Instead, the reserves are a tool with which to further government policy (usually exchange rate 
policy or monetary policy). This means that the assets in the reserves must always be available. Not only are they there to be used, they are there to be used in their entirety if the person controlling them, usually the Finance Minister, wishes them to be, and they are there to be used whenever he or she says. A central bank has to be able to supply cash, up to the full amount of the reserves it holds, whenever policy dictates that the reserves need to be used. And since central banks do not know when they are going to be asked to call upon the reserves, and they do not know how much of those reserves are going to be called upon, they will always value liquidity extremely highly. If a central bank holds reserves but cannot liquefy them in a crisis, it negates the rationale for holding those reserves.

The third common feature is that the reserves are often relatively large. This has been particularly the case in recent years and it is particularly the case in Asia. Some of the Asian central banks have created large portfolios indeed; so large that, despite the comments above, they must really now be considered as containing elements of "store of wealth" functions, as well as being tools of monetary policy and the other usual uses of the reserves. But even for countries where this is not the case, the reserves are of ten a substantial sum compared to the rest of the government's finances. Therefore, returns on the reserves are not unimportant, and it is legitimate for the managers of the reserves to try to maximize that return. In some countries, there is some discussion as to whether a profit-maximizing motive is entirely appropriate for the public sector. Many public sectors have a slightly puritanical view of profit, as if it was something only the private sector was suited to or even able to pursue. Increasingly, however, such sentiments are losing favor, and the pursuit of returns is seen as a legitimate and central element of official reserves management. This is not just true where, as in Asia, the reserves are large relative to national economies. It is now widely accepted as valid for all central banks.

It is not, therefore, surprising that most central banks now agree on the classic "trilogy" of objectives of of ficial reserves management. The three objectives are security, liquidity, and profit. Furthermore, most also agree that security and liquidity are dominant, with the pursuit of extra returns being conducted subject to adequate security and liquidity being maintained. 


\section{Evolution of Official Reserves Management Since the 1960s}

To understand the current state of play in official reserves management, it is useful to consider a brief and simplified history of the subject. During the heyday of the Bretton Woods era, foreign currency reserves were almost entirely a tool for exchange rate control. They were not, by today's standards, large but this was not a significant issue because neither the foreign exchange markets, nor indeed the central banks, were particularly sophisticated or aggressive, at least initially. (It is interesting to consider the scale of intervention in earlier days: if we go back before the Bretton Woods era to the gold standard between the wars, the intervention carried out by the United Kingdom in defense of sterling in the 1930s was about $\$ 10$ million on one day followed by about \&.18 million the next day. These figures were considered huge, and indeed unsustainable, and the United Kingdom elected to leave the gold standard rather than continue such intervention.)

Toward the end of the 1960s, pressures built up on the Bretton Woods system and eventually caused it to bieak down. Markets became more aware of their power to move exchange rates and less willing to accept the word of central banks as absolute. The newly floating exchange rates moved around with considerable volatility, and there were some notable early successes for "market forces" over the authorities. For example, the pound sterling, which went into the European Economic Community's "snake" in mid-1972, was forced to leave it six weeks later. However, central banks were quite slow to respond to the markets. Reserves management remained little more than liquidity management, with a high emphasis on security. Moreover, profit, the third of the three objectives of modern reserves management, remained almost totally ignored. Indeed, the common analysis was that reserves were necessary for policy reasons, and there was an inevitable cost to holding them, which was to be seen as a cost of policy. In many central banks, it was not even measured, and as a result was not a subject of any analysis or discussion either within the authorities themselves or in a wider public forum.

This could not continue forever, however, and as the 1970s progressed, and currency volatility did not decrease, central banks began increasingly to measure these costs. This inevitably and 
swiftly led to consideration of how the costs could be minimized. This was a common learning process for most central banks, and most central banks have now gone through it sometime in the past.

The 1970s was a volatile time, not just for currencies but also for interest rates. The energy crisis in the real world led to financial markets, particularly interest rate markets, becoming much more volatile. This encouraged central banks to reconsider their passive attitude to reserves management, particularly those central banks that had reserves on their own balance sheet-and were therefore themselves directly affected by changes in the valuations of their foreign currency holdings. A general awareness among central banks of the currency and interest rate mismatches that they were running in their holding of the reserves became much more common, and with it a desire to minimize the risks attached.

At the same time, as markets were becoming more volatile, two other developments were taking place. Markets were becoming much more accessible to international investors in general and central banks in particular, and spurred by this, tools for managing the risks were being developed, enabling investors to amend their portfolios to fine-tune their positions and control their risks. All of this led to both a growing desire and a growing ability to manage foreign currency reserves more actively. There was both the need, because the risks in the balance sheet had been displayed graphically by the volatility in the markets, and there was the ability to do so, created by the new instruments that were then gaining ground and acceptance. Furthermore, once central banks began to manage their reserves more actively, they quickly became aware that the costs connected with holding reserves were not inevitable and could be reduced by active management. Indeed, central banks increasingly began to focus on the opportunities for profit and for making genuine returns.

The high interest rates of the early 1980s, largely a consequence of Paul Volcker's policy at the Federal Reserve, enabled those who held long-term fixed income assets to make large gains as the decade unwound. Long-term interest rates have generally fallen overall throughout the past 15 years, but this was particularly pronounced in the five years from December 1981, the period when many central banks were for the first time moving to much more active reserves management. Although bonds did not produce positive returns every year, it became clear to central banks that there 
was money to be made in longer-term securities and that they could therefore go beyond their original home in the money markets to their advantage.

Equally, the development of a Eurodollar market (indeed, Euromarkets in general, but predominantly Eurodollars) seemed to offer central banks almost risk-free anomaly arbitrage. It was attractive for a central bank to buy bonds when they were at good spreads to the underlying government market, and then hold them until they had tightened in, perhaps as the primary supply was absorbed. This "warehousing" of bonds was profitable and almost risk-free provided that the central bank was not forced to sell the bonds before they had appreciated: since, in general, central banks were not publishing their investment results frequently (not even to internal management), they were able to hold onto positions for longer than most investors, and such strategies were therefore ideal. Even after the then rather wide bid-offer spreads in the Euromarkets, it paid handsomely for central bank reserves managers. This, again, therefore rewarded a more active and profit-oriented style.

As a result of these developments, profits became not just an acceptable motive, but in some cases large. These were a welcome addition to national treasuries, particularly those that were beginning to feel in the late 1980 s the pressure to rectify fiscal excesses of the early 1980s and late 1970s. Some of the other papers at this conference have detailed how the excesses during this period were entered into, and the consequences of such profligacy. Treasury ministries have found profits on reserves management or profits on central banks as a whole a useful source of funds to help them rectify this position, and for this reason, too, active reserves management for profit was encouraged.

There were obviously some interested bystanders to this development-in particular, the securities houses. They were quick to welcome this major new class of investor, who represented highquality customers for them. Many securities houses set up training courses and seminars for central bankers, and this was yet another boost to the by now widespread acceptance that it was appropriate for central banks to run their reserves management operations as a profit center.

The 1990s have, however, on balance been less encouraging for central bank reserves managers. The markets have become increasingly liquid and sophisticated, which has greatly reduced profit op- 
portunities from anomaly trading. In particular, the actions of the central banks themselves in the Euromarkets mean that the easy, almost risk-free anomaly arbitrage plays have now largely disappeared. Unfortunately, national finance ministries are still under pressure, and central banks and their governments have been reluctant to forgo the profits that they are now used to. As a result, many central banks have had to reconsider their strategy if they wish to continue to generate the level of profits from their reserves that they have become used to. Clearly, one way to do this has been to move out along the risk curve and take on more risky strategies. Some central banks have done this knowingly, and perhaps rather more central banks have done so unwittingly, without fully realizing what they were doing.

This change of style has greatly increased the requirements for computer support, risk control systems, and the like. Many central banks base much of their information technology (IT) support for reserves management on systems built largely in-house, and these are seldom at the leading edge of the market. Keeping abreast of developments in IT support for complex market operations is expensive, as the securities houses themselves have shown with their commitments in this sphere, and few central banks have the budget to keep their systems as far advanced as they would ideally like.

Moreover, the greater complexity of the markets in which central banks invest, and of their own operations, has also placed great demands on their investment staff. These staff are increasingly asked to operate much more like their private sector counterparts in the fund management industry. Yet, whereas national debt offices are sometimes able to escape the civil service pay scale, central banks find it much more difficult to match market rates of pay for their reserves management staff, who typically represent only a small proportion of their overall establishment. This similarity of the work with the private sector, coupled with the difference in salary scales, has meant that many central banks operate under the expectation of losing experienced staff after a few years in the reserves management area.

These factors have led to central bank reserves management operations often being slightly understaffed and slightly underresourced, with experience at a premium. It is difficult to keep staff and, therefore, keep experience. And IT systems are often not quite as good as they should be, given the size and nature of public as- 
sets under management. The volatile markets of the past few years, particularly in 1993 and 1994, have further stretched central banks.

To summarize, the passive in-house management style adopted in the 1970s has been replaced by a much more active style, profitseeking approach. Profit is now widely seen as a legitimate objective, albeit still as the third of the three in the reserves managers' trilogy. This has posed new challenges as market complexity and volatility increases. In retrospect, the 1980s saw central banks catching up and narrowing the gap on the market in terms of their level of sophistication but, more recently, they have been falling behind again. The market, as it were, has taken another leap forward, particularly in IT, and central banks are faced with the challenge of maintaining staffing and systems at the necessary level. And, as a corollary, the possibility of outright losses from central banks' reserves management operations has therefore grown.

\section{Focus on Risk Control and Use of Balance Sheets}

Partly with the increased possibility of losses, attention to risk has also grown. Investors generally are increasingly focusing on risk as well as return, and central banks are not immune from this. Risk has always been an important part of investment analysis, but it is particularly appropriate for central banks to focus on this because it is at the core of their position as trustees of public assets. It could be said, indeed, that the avoidance of unacceptable losses is the essence of managing public funds.

One important decision is whether the assets are managed on their own as an asset portfolio, or in conjunction with a set of liabilities. Iet us first consider the position where foreign exchange reserves are managed in isolation from foreign exchange liabilities. This is much the more common approach, and the usual arrangement in such a situation is that the reserves are held on the central bank's own balance sheet. This is particularly common in Europe: most central banks in Europe hold their country's reserves on their own balance sheet but do not hold their country's liabilities. It may be that the country has no public sector foreign exchange liabilities. This is the case in the Netherlands or in Germany, for example. Or else they may be held at the Ministry of Finance or National Debt Office. 
Table 9.1. A Central Bank Balance Sheet

\begin{tabular}{ll}
\hline Liabilities & Assets \\
\hline Banks' balances and other accounts & Fixed assets \\
Note issue & Domestic securities \\
Reserves and accumulated profits & Other domestic assets/accounts \\
Shareholders' capival & Foreign currency reserves
\end{tabular}

The central bank's balance sheet, therefore, looks similar to that shown in Table 9.1. On the liability side, there are capital and reserves, the note issue, and banks' balances and possibly some other accounts. On the asset side, there will be fixed assets, the foreign currency reserves, some domestic securities, and perhaps other assets.

From a risk-control viewpoint, the most obvious feature of such a balance sheet is that it carries unavoidable currency risks because the liabilities are all in domestic currency, whereas not all the assets are, and largely unavoidable interest rate risks because, while most of the liabilities are at floating rate (or indeed free, like the note issue), this will not necessarily be the case for the assets. Moreover, because management of the central bank's balance sheet is likely to be undertaken by a different area of the bank from the reserves managers, the focus on these risks may not be a priority. Also, there may be difficulties in managing the balance sheet too actively because of interference with the operation of monetary policy. A central bank's balance sheet can of course be managed but, in many senses, it is a fairly reactive balance sheet.

Even where the central bank does wish to set a benclımark for reserves, such a balance sheet offers no clear guide as to what this benchmark should be. There are no particular liabilities specified as the counterpart to the reserves, and no obvious reason to choose one neutral currency mix or interest rate profile as opposed to any other. One possible solution is to discuss benchmarks with the country's debt office or the Ministry of Finance, or whoever is responsible for the foreign currency liabilities. But there are potential conflicts here, because what is ideal for the debt office, in terms of what is the best profile for the debt, may not be the best profile for the reserves in the context of this balance sheet. In the context of this balance sheet, the central bank may well wish to minimize in- 
terest rate risk, which would imply holding either short duration or floating rate assets as a majority of their assets. This is not a policy likely to be optimal for the debt office.

The alternative approach, and the one used by the Bank of England, is to manage foreign exchange liabilities and assets together. There are several options for the balance sheet under such a regime, depending on the ownership of the assets and liabilities. There is a difference here between "manage" and "own." In the United Kingdom's case, the bank does not own either the assets or the liabilities; both remain in the name of Her Majesty's Treasury and the bank acts as manager for both the assets and liabilities. But the analysis is sinilar in the case where the central bank has both assets and liabilities on its own balance sheet (for example, the Hong Kong Monetary Authority), or even where the central bank and the rest of govemment enter into some formal agreement to transfer the liabilities from one to the other (for example, an off-market exchange of obligations between the central bank and the government).

There are several options for the balance sheet under such a regime, and the United Kingdom's is shown in Table 9.2. On the liabilities side are foreign currency liabilities and what is described as owner's capital. On the assets side, there are assets hedging the liabilities and net assets. Since the United Kingdom's foreign exchange reserves exceed the foreign borrowing, net foreign exchange assets are positive and on the assets side.

The "owner's capital" is an essential part of this balance sheet. It is the counterpart to the net foreign exchange assets and is the equivalent of the shareholders' capital and reserves on the previous balance sheet. One of the advantages of this approach is that it enables the managers of the balance sheet to focus on this element and therefore on the net foreign currency reserves. This focus can help the central bank assess its response to two questions that are traditionally difficult for reserves managers to answer-namely,

Table 9.2. Balance Sheet Management in the United Kingdom

\begin{tabular}{ll} 
Liabilities & Assets \\
\hline $\begin{array}{l}\text { Foreign exchange liabilities } \\
\text { (i.e., foreign exchange borrowings) }\end{array}$ & $\begin{array}{c}\text { Foreign exchange reserves hedging lia- } \\
\text { bilities }\end{array}$ \\
$\begin{array}{ll}\text { Ownet's capital } & \text { Net foreign exchange reserves }\end{array}$ \\
\hline
\end{tabular}


when should the country borrow to finance the reserves? And, when should it run down the reserves to pay back the borrowing? For the United Kingdom, these questions are at the forefront of the discussion of the optimum size of the reserves, because the United Kingdom only borrows in foreign currency to provide reserves. Any foreign currency borrowing is added to the reserves (to the balance sheet) rather than sold for domestic currency to fund the government's borrowing requirement.

In the United Kingdom, the owner's capital entry is assumed to be a sterling liability. This is because, if the Chancellor of the Exchequer wished, he or she could ask the bank to sell the net reserves for sterling, thereby cutting the government's borrowing requirement in the domestic market. Further questions then arise as to the interest rate to put on these theoretical liabilities, and their term. These are nontrivial questions, and the bank finds the balance sheet approach useful in making the relevant decisions.

It used to be considered that the owner's capital (the sterling liabilities on the foreign exchange balance sheet) should be considered as being at the same maturity as the United Kingdom's domestic borrowing in the gilt market. At the time, the average maturity of United Kingdom domestic borrowing was about five years. Therefore, the hypothetical maturity of the owner's capital was also put at five years, and this led to the bank holding foreign currency assets with a maturity of about four to five years as well. More recently, the correctness of this has been reconsidered, and there is more of a tendency now to consider that the sterling liabilities on the balance sheet are held at floating rate, and therefore the net foreign exchange assets that the bank manages on behalf of the Treasury also tend to be floating rate money market instruments.

\section{Benefits of the Balance Sheet Approach}

The balance sheet approach has several consequential advantages. First, for much of the foreign currency assets, there is a natural benchmark-the liabilities. The currency and interest rate risks on the assets held to hedge the liabilities can be eliminated almost completely by holding the assets to match exactly (or as near exactly as the managers wish) the cash flow obligations of the borrowings. 
Second, discussion is directed to the size and composition of the net reserves. The construction of the balance sheet highlights that this is the part that carries excess risk. It remains the part of that balance sheet where market movements can affect the overall position. By focusing directly on the net reserves, attention is directed to the part of the balance sheet at risk, and questions such as the size, maturity, and composition of those net reserves can be assessed. This is valuable, because these are areas that central banks typically do not spend a great deal of time on.

For the United Kingdom and other European Union central banks, these questions are becoming timely as European Monetary Union approaches, both because the European Central Bank will be creating its balance sheet afresh with no constraints from existing obligations and accounting principles, and because member central banks will wish to consider what the optimum size of their reserves are when they no longer have direct responsibility themselves for their currency. The Bank of England does find that the balance sheet approach sheds a new perspective on the debate, and, in discussion with central bank colleagues from elsewhere in the European Union, some of the ideas that we bring to the table are rather different because of our different approach.

Another major advantage of this approach is that attention is focused on the need to make a realistic assessment of the cost of holding reserves, particularly net reserves. This is important, because unless the cost of holding reserves is known, one cannot answer questions such as the optimum size of the net or gross reserves.

Finally, the balance sheet approach also raises the possibility of using manipulation of the liabilities side of the balance sheet to achieve a desired overall risk position or a desired position in the markets. Such operations are less easy for central bank reserves managers who have responsibility only for the assets and who may have no relationship with the owner of the liabilities.

\section{Conclusions}

This paper has considered the evolution of central bank reserves management and has argued that a balance sheet approach has many merits in assisting the authorities on some of the more diffi- 
cult policy decisions connected with reserves management. Three main conclusions can be drawn.

First, modern markets place a great emphasis on risk control as the key to successful asset management, and this is as true for a central bank managing a country's reserves as for those managing a mutual fund, a pension scheme, or whatever.

Second, from a national perspective, risks inherent in holding foreign currency reserves are best managed at as high and as aggregate a level as possible. The Bank of England's experience is that if risks are disaggregated excessively, then control is sacrificed and the accumulation of a large number of small risks can become an unacceptably large risk, whereas if a country's foreign exchange position can be aggregated at a high level, the overall risk can be assessed and therefore minimized.

Third, where the institutional framework permits, there is much merit in taking assets and liabilities together. This is not always possible, and for countries where it is not possible to do this, or where there are independent agencies managing the two halves of the balance sheet, the challenge becomes one of communications and identifying a common objective that does not interfere with their separate objectives. But, where the institutional framework permits (as it does in the United Kingdom), there is much merit in the balance sheet approach. Furthermore, even where the government does not have any foreign liabilities, there are nevertheless notional liabilities against which the foreign currency assets are being held, because there is always the possibility that they can be sold for domestic currency, and there is always something, therefore, on the other side from the assets, even if it is only an opportunity cost. So, even where there are no foreign liabilities, the balance sheet approach does highlight the opportunity costs and risks of holding net reserves. 


\title{
10
}

\section{Trends in Central Bank Reserves Management}

\author{
Jean-François Rigaudy
}

his paper reviews trends in central bank reserves management
over recent years. ${ }^{1}$ It draws upon theoretical and statistical work prepared in various areas of the Bank for International Settlements (Monetary and Economic Department, Banking Department) and upon our own experience from contacts with central bank reserves managers.

Admittedly, an exercise that intends to identify the main trends and key factors runs the risk of oversimplification-since the world of central banks is made up of a wide spectrum of organizations, functions, and responsibilities. As a result of these differences, there is a great variety of ways in which central banks approach the question of reserves management. The matter is further complicated by the fact that confidentiality is often an important factor for central banks. Nevertheless, we have made every effort to guard against excessive generalizations. Some common features, however, can be identified:

- Despite theoretical literature on the optimal level of reserves, their size is, most of the time and in most of the countries, a consequence of economic policy and particularly monetary policy or foreign exchange policy at the central bank. Few central banks have a reserve objective per se, although the size of

'See Scott Roger, "The Management of Foreign Exchange Reserves," and "Overview of Reserve Management by Central Banks," a paper presented in Florence in 1994 by Jean-François Rigaudy and in Cartagena by Pierre Cardon. 
reserves could in some cases represent an additional (and acute) constraint to economic policy.

- Central banks hold reserves usuaily for three main reasons, namely: transaction needs, intervention purposes, and wealth accumulation. Each central bank has its own combination of these three features and no particular one appears to have been dominant over recent years. In addition, Goldstein and Turner have shown that a healthy cushion of international reserves appears to have taken on added importance for preventing crises in domestic banking systems in emerging market economies. ${ }^{2}$

This paper investigates the main statistical changes in foreign exchange reserves within the past few years. It then describes some significant changes that have taken place with regard to the objectives and investment policies of central banks. Finaliy, it points out some trends that could noticeably slow or even reverse these recent changes.

\section{Evolution of Foreign Exchange Reserves}

Foreign exchange reserves have grown at an increasing rate in recent years, while the currency composition of reserves has remained relatively constant. This has coincided with the trend toward a more integrated global economy. In the years up to 1996, the nominal size of reserves in dollar terms increased at an average annual rate of 14.3 percent (11.3 percent in 1993, 14.8 percent in 1994, and 16.8 percent in 1995). The growth in reserves in 1994 and 1995 was at least two percentage points higher than the 1986-92 average annual growth rate of $\mathbf{1 2 . 9}$ percent. This growth in reserves has not been symmetric between industrialized countries and emerging market economies (see Figures 10.1 and 10.2, and Table 10.1). From 1993 to 1995, industrialized countries experienced a slower growth in reserves than during the period from 1986 to 1992 (10.1 percent average annual growth rate against 11.2 percent), while over the same period, the foreign exchange reserves of emerging market economies grew at a rate of 18.7 percent--compared with 15.2 per-

2See Goldstein and Turner, "Banking Crises in Emerging Economies: Origins and Policy Options." 
Figure 10.1. World Foreign Exchange Reserves

(In billions of U.S. dollars)

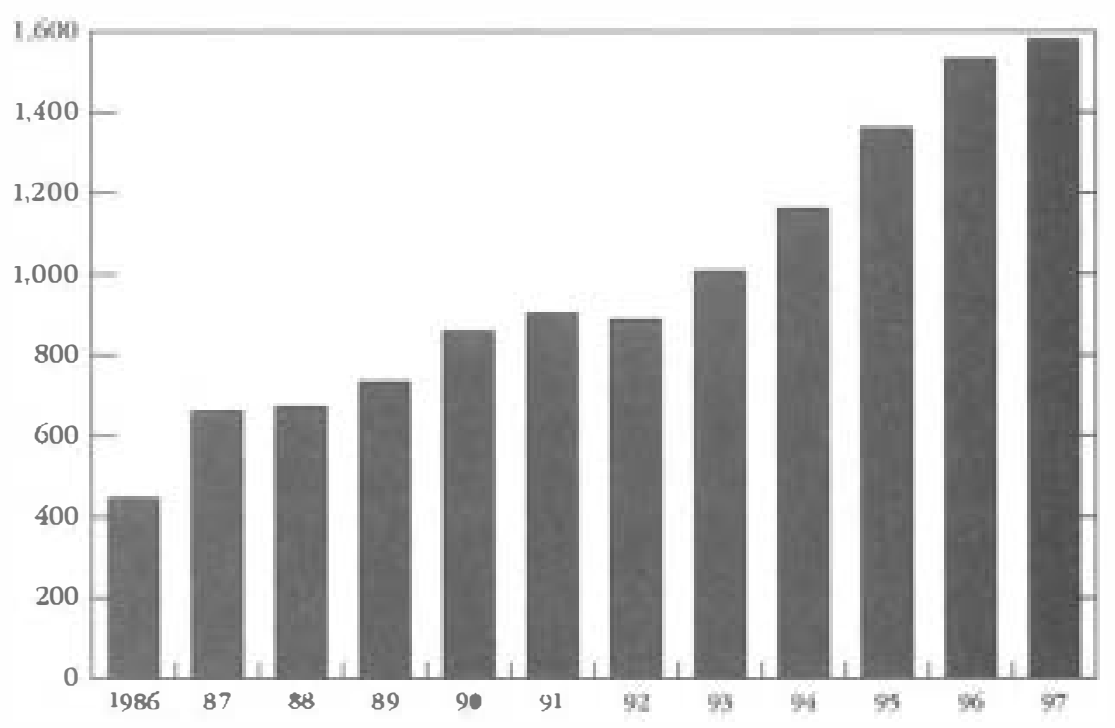

Source: IMT, International Financtal Statistics.

cent during the period from 1986 to 1992. As a consequence of this faster rate of growth, by the end of 1995 , the total foreign exchange reserves of all central banks had reached a combined amount of $\$ 1,382$ billion, of which $\$ 655$ billion ( 47.4 percent) were held by central banks of industrialized countries and $\$ 727$ billion (52.6 percent) were held by central banks of emerging market economies. Thus, the sharp growth in the reserves of developing countries has led to a major shift in the distribution of world reserves. Industrialized countries no longer hold the major portion of world foreign exchange reserves. ${ }^{3}$

Within the industrialized group of countries, Japan has been the one exception to the trend toward slower growth in reserves in recent years. In Japan, foreign exchange reserves increased 40.7 per-

3The average percentage of reserves held by industrialized countries between 1985 and 1994 was 57 percent. 
Figure 10.2. Shares of Total Foreign Exchange Reserves

(In percent)

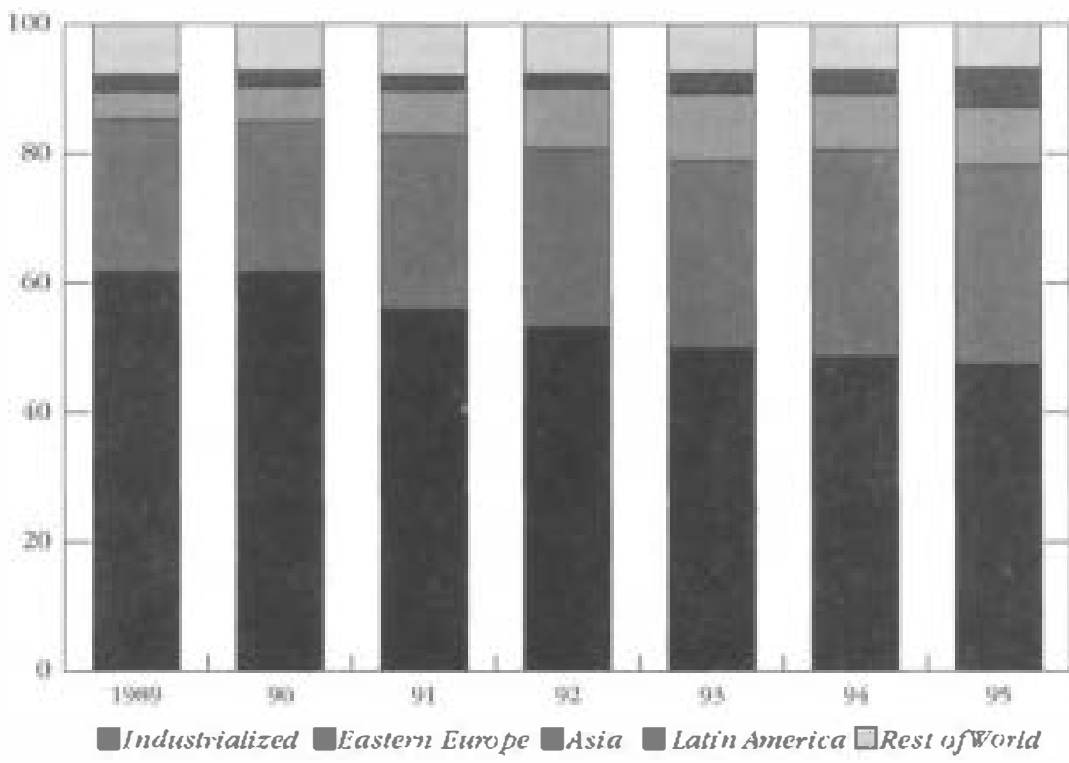

Source: MiF, Imeernational fintanclal Stutistios.

Table 10.1. Annual Growth in Foreign Exchange Reserves ${ }^{1}$

\begin{tabular}{|c|c|c|c|c|c|c|c|}
\hline Ceuntry Type & $1986-92^{2}$ & 1991 & 1992 & 1993 & $199 t$ & 1995 & $1993-95$ \\
\hline Werkd & 12.9 & 6.2 & 0.11 & 11.3 & $1 \cdot 4.8$ & 16.8 & l. 3 \\
\hline Industrial countries & 11.2 & -3.7 & -4.8 & 4.6 & 12.0 & 13.7 & 10.1 \\
\hline$G-10$ & 10.1 & -8.9 & 0.68 & 4.2 & 12.8 & 17.6 & 115 \\
\hline United States & 14.9 & -11.9 & -12.9 & 3.8 & -0.8 & 19.1 & 7.0 \\
\hline Japan & 8.6 & -11.1 & 0.21 & 43.1 & 29.8 & . 99.8 & 40.7 \\
\hline Germany & 11.0 & -8.6 & 49.3 & -15.3 & -0.7 & 7.7 & -3.3 \\
\hline Emerging markels & 15.2 & 22.3 & 6.3 & 18.9 & 17.5 & 19.6 & 18.7 \\
\hline Asia & 17.9 & 22.8 & 2.6 & 17.0 & 26.1 & 12.2 & 18.3 \\
\hline Iatin America & 20.6 & 39.2 & 39.4 & 23.5 & -5.7 & 16.3 & 13.2 \\
\hline Eastern Europe & 13.6 & 1.2 & -7.5 & 66.8 & 26.5 & $95 .+1$ & 60.3 \\
\hline \multicolumn{8}{|l|}{ Total foreign } \\
\hline \multicolumn{2}{|c|}{ exchange reserves 3} & 923 & 92\{ & 1,029 & 1.182 & 1,382 & \\
\hline
\end{tabular}

Sources- $M_{M F}$, national data, and BIS.

'All numbers are presented in percentage terıns.

2Annualized growth over the entire period.

${ }^{2}$ These numbers are expressed an billions' of U.S. dellars. 
cent on average per year between 1993 and 1995, whereas the level of reserves in other developed countries remained relatively stable. Among industrialized countries, at the end of 1995, the bulk of the reserves were held by Japan ( $\$ 172.4$ billion), Germany ( $\$ 60.2$ billion), and the United States ( $\$ 49.1$ billion).

During the same period, the reserves of emerging market economies swelled and caused their share of the total to reach more than 50 percent. However, the growth was different between regions. In Latin America, foreign exchange reserves grew much slower over those three years (13.2 percent average annual growth rate) than they did in 1986-92 (20.6 percent). The level of Latin American reserves was $\$ 125.2$ billion at the end of 1995 . Also, although Eastern European countries experienced an impressive 60.3 percent average annual growth rate from 1993 to 1995 compared with the 13.6 percent average annual growth from 1986 to 1992 , the total level of reserves held by central banks of that region were still small in relative terms ( $\$ 82.8$ billion). In March, the largest contribution to the rapid growth of reserves was taking place in Asian emerging market economies. Foreign exchange reserves of this region, which amounted to $\$ 423.6$ billion at the end of 1995 , had grown steadily at an average of 18 percent a year since 1986.

The size ( $\$ 1,382$ billion) and growth of foreign exchange reserves (14.3 percent from 1992-95) can be put into perspective by comparing it to world foreign exchange activity. As of April 1995, the average daily turnover of global foreign exchange markets (composed of spot, outright forward, and foreign exchange swap contracts) was estimated to be nearly $\$ 1.2$ trillion ( $\$ 1,190$ billion). ${ }^{4}$ Furthermore, between 1992 and 1995, foreign exchange transactions increased by 45 percent or 12 percent annually. The size of total reserves ( $\$ 1,382$ billion) grew at an annual rate of 14.3 percent over 1993-95. Although there might be no logical link between these figures, it is nevertheless interesting to note the similarity between the growth in reserves and the growth in global foreign exchange turnover (see Figure 10.3).

Part of the enormous increase in world reserves in recent years is attributable to factors such as the accumulation of interest, central bank foreign exchange activity, and increased trade and capital

\footnotetext{
${ }^{4}$ See BIS, "Central Bank Survey of Foreign Exchange and Derivatives Market Activity 1995."
} 
Figure 10.3. World Global Foreign Exchange Turnover and Foreign Exchange Reserves

(In billions of (IS. dollars)

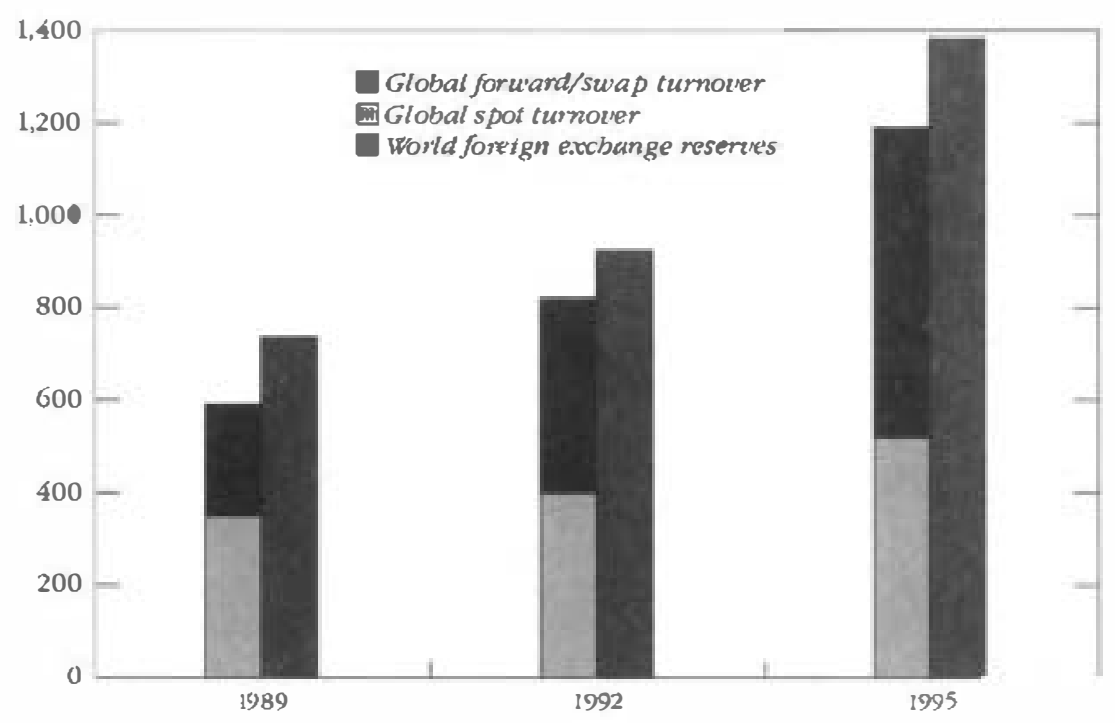

Source: Bank for lnternational Settlements (Bis).

flows. Some idea of how much the growth in reserves arises from pure interest accumulation may be gained by calculating since 1986 the proceeds of investing the reserve total for each currency in the respective three-month LIBID (London Interbank Bid Rate) index, and converting back into U.S. dollars at each year-end. This approximates to separating out the accumulation of reserves purely attributable to leaving the funds in liquid assets. In fact, this rough calculation shows that as of year-end 1995, 47.2 percent of reserve growth from 1985 to 1995 in dollar terms would have been obtained from merely investing in three-month LIBID instruments and converting the returns into dollars (see Figure 10.4).

Finally, it is interesting to compare the growth in reserves in different geographical regions with standard criteria for determining the adequate level of reserve holdings. The optimal level of reserves will certainly differ from country to country. One well-known rule of thumb is to have a level of reserves that covers three months of imports. Another approach is to determine a reserve level upon the 
Figure 10.4. Foreign Exchange Reserves Over Time (In billions of U.S dollars)

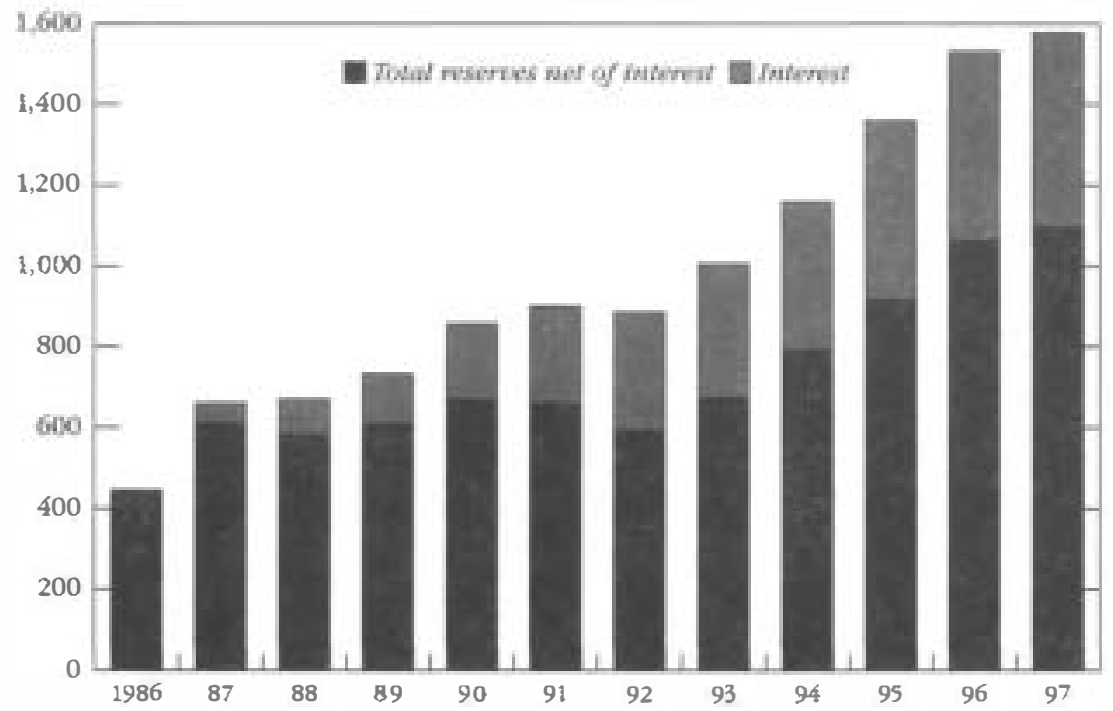

Source: Bank for Intemational Settlements (BIS).

contribution of trade to GDP, more commonly known as the average propensity to trade. The average propensity to trade is usually the ratio of exports to imports or an average of the two to GDP. Although there has been no exact preferred ratio established, the general idea is that a countiy might want relatively more reserves when its trade-to-GDP ratio is higher. Yet another method to assess an appropriate level of reserves, suggested by Scott Roger, is to examine current account variability by measuring the standard deviation of current account changes each year. ${ }^{5}$

Most of these measures are included in Table 10.2, which compares the evolution between two periods-1985 to 1991, and 1991 to 1995 . Column 2 of the table identifies a country or synthesizes a "representative" country by taking an average of the reserves of each country in the region (weighted according to their share of the total). To examine the evolution of reserves, three methodologies for determining reserve levels, summarized in the previous para-

sSee Scott Roger, "The Management of Foreign Exchange Reserves." 
Table 10.2. Nominal Foreign Exchange Reserves and Various Metrics

\begin{tabular}{|c|c|c|c|c|c|c|c|}
\hline 1 & 2 & 3 & 4 & 5 & 6 & 7 & 8 \\
\hline \multirow[t]{2}{*}{ Country } & $\begin{array}{l}\text { Avcragc" } \\
\text { in billions } \\
\text { of u.s. } \\
\text { defilars) }\end{array}$ & $\begin{array}{c}\text { Forcign } \\
\text { exchange/ } \\
\text { (rade } \\
\text { (Percent) }\end{array}$ & $\begin{array}{l}\text { Trade' } \\
\text { Month } \\
\text { cover } \\
\text { (Mon'bs) }\end{array}$ & $\begin{array}{c}\text { Trade } \\
\text { GUP } \\
\text { (Percem) }\end{array}$ & $\begin{array}{l}\text { Curtent } \\
\text { Account } \\
\text { S.D. } \\
\text { (In billens } \\
\text { of U.S. } \\
\text { dolicirs) }\end{array}$ & $\begin{array}{l}\text { Volatility } \\
\text { Foreign } \\
\text { exchange } \\
\text { C.A. }\end{array}$ & $\begin{array}{l}\text { lotats } \\
\text { (in billtons } \\
\text { of U.S. } \\
\text { dollars) }\end{array}$ \\
\hline & & \multicolumn{3}{|c|}{$1 \% 1$ to 1995} & \multicolumn{2}{|c|}{1991 to 1995} & 1995 \\
\hline Industrial & $\$ 8.1$ & 23.5 & 2.8 & 24.5 & 16.3 & 2.9 & 655.6 \\
\hline$G-10$ & 55.6 & 18.2 & 2.1 & 23.0 & 26.6 & 2.7 & 510.5 \\
\hline Uniled Stales & 43.4 & 6.2 & 0.7 & 10.5 & 57.3 & 0.6 & 49.1 \\
\hline Japan & 92.3 & 24.9 & 2.9 & 8.7 & 25.5 & 3.5 & 172.4 \\
\hline Germany & 72.6 & 14.4 & 1.7 & 25.0 & 29.5 & 3.3 & 60.2 \\
\hline Asia & $\$ 9.6$ & 53.8 & 6.4 & 629 & 4.2 & 11.6 & 423.6 \\
\hline Latin America & 17.9 & 61.8 & 7.4 & 17.7 & 6.3 & 2.8 & 125.2 \\
\hline \multirow[t]{2}{*}{ Eastem Europe } & 5.9 & 30.8 & 3.6 & 30.3 & 3.4 & 1.7 & 82.8 \\
\hline & & \multicolumn{3}{|c|}{1985 to 1991} & \multicolumn{2}{|c|}{1985101991} & 1991 \\
\hline Induserial & 33.8 & 23.2 & 2.7 & 25.6 & 13.1 & 2.6 & 515.5 \\
\hline G.10 & 38.7 & 18.6 & 2.2 & 24.6 & 16.3 & 2.3 & 365.5 \\
\hline Unitcel Stales & 24.5 & 5.2 & 0.6 & 9.2 & 40.4 & 0.6 & 45.9 \\
\hline Japan & 56.8 & 23.1 & 2.7 & 9.9 & 23.9 & 2.3 & 61.7 \\
\hline Germany & 54.3 & 16.6 & 1.9 & 28.9 & 28.9 & 2.3 & 57.5 \\
\hline Asia & 33.3 & 67.3 & 8.0 & 552 & 3.9 & 8.4 & 249.0 \\
\hline Latin Americs & 6.2 & 38.1 & 4.5 & 16.3 & 3.6 & 1.7 & 63.4 \\
\hline Eastem Europe & 2.2 & 16.3 & 1.9 & 27.5 & 1.9 & 1.1 & 21.7 \\
\hline
\end{tabular}

Source: lMF, International Financial Statistics, national data; and BIS.

Nete: Asia = China, lndia, Hong Kong SAR, Korea, Singapore, Taiwan Provine of China. Indonesia, Malaysia, Philippines, and Thailand; Latin Anerica - Argentina, Brazil, Chile. Colombia, Mexico, Peru, and venezuela; and Eastern Europe - Czech Republic, Hungany, Poland, Romania. and Turkey.

ITrade is defined as the sum of exports and imports divided by two.

2Average stands for average of foreign exchange reserves and is computed by taking a geometric mean for each of the countries over the given period. For groups of countries, such as the G-10, a weighted average of all the countries within the group is taken to get the final figure. The weights are based upon percentage holding of foreign exchange reserves. This methodology attempts to capture a representative figure of that region based upon its share of foreign exchange holdings. This is in no way a "representative" country in terms of economic weight (as indicated by GDP); however, it may be a more interesting weight to analyze world foreign exchange reserves

${ }^{3}$ S.D. represents the standard deviation of annual current account clanges.

tThis figure is the ratio of the average foreign exchange reserves over the period to the current account variability as defined by its standard deviation.

SThe total figures represent the total foreign exchange reserves of each region as of the ending period. In the upper panel, this is as of end-1995 and in the lower panel, this is as of end1991 . 
graph, are compared for different regions over the two periods. Column 4 of the table represents the average month cover of foreign exchange reserves for various countries and "representative" countries of different regions. It indicates that for industrial countries, the G-10, the United States, Japan, and Germany, foreign exchange reserves have adjusted to the increase or decrease in trade experienced by them in recent years. In other words, the ratios have remained relatively constant between the two periods. For Asian countries, these ratios have decreased. This indicates that for the "representative" country in Asia, growth in trade has outpaced the growth in reserves-a point of some significance in the light of the recent enormous growth in Asian reserves. Despite the decrease in this ratio for Asia, ratios there were still three times as high as the ratio for the representative G-10 country.

It is at this point that column 5 is interesting. One will notice that the Asian trade-to-GDP ratio is three times that of the G-10 representative. It might be quite logical for Asian countries to have more reserves given the importance of trade in their economies. For Eastern Europe and Latin America, the month cover actually increased. Finally, one may observe the evolution of the current account criterion in columns 7 and 8 . Overall, current account variability has not changed much from the earlier period, except for the United States. The ratio of foreign exchange reserves to current account variability (column 8 ) has remained relatively stable for most countries, except Japan, Asia, and Latin America. Japan's figure increased by approximately 30 percent, Asia's by about the same amount, and that of Latin America by roughly 60 percent. Thus, if one believes that current account variability is a reasonable criterion to judge the adequacy of foreign exchange reserve holdings, then the Asian resemves had increased by too much-- or conditions had changed so as to require a higher ratio.

Perhaps the most telling story from these figures is that the growth in Asian and Japanese foreign exchange reserves was so substantial. While some measures indicate that the growth was either sufficient or too little as a consequence of economic events, other measures indicated that this growth had exceeded what was warranted.

Over the same period, the composition of reserves, excluding gold, has remained relatively constant. Since 1970 , there has been a decline in the percentage of U.S. dollar reserves within the overall total, though this decline has stabilized in recent years (see Table 
Table 10.3. Currency Composition of Foreign Exchange Reserves 1

\begin{tabular}{lrrrrrrrr}
\hline Currency & 1970 & 1980 & 1984 & 1991 & 1992 & 1993 & 1994 & 1995 \\
\hline U.S. dollar & \multicolumn{1}{c}{ T7.2 } & 67.2 & 68.3 & 56.2 & 60.9 & 61.4 & 60.7 & 61.4 \\
Japanese yen & n.a. & 4.3 & 6.1 & 9.3 & 8.6 & 8.5 & 8.8 & 7.6 \\
Deutsche mark & 1.9 & 14.8 & 13.6 & 16.9 & 15.0 & 15.6 & 15.9 & 16.1 \\
Pound sterling & 10.4 & 2.9 & 2.6 & 3.1 & 2.9 & 3.3 & 3.0 & 3.0 \\
French franc & 1.1 & 1.7 & 0.8 & 2.4 & 2.1 & 2.0 & 1.9 & 1.9 \\
Durch guilder & n.a. & n.a. & 0.7 & 0.9 & 0.5 & 0.5 & 2.5 & 0.3 \\
Swiss franc & 0.7 & 3.2 & 1.9 & 1.1 & 1.0 & 1.1 & 2.2 & 0.8 \\
Private ECU & n.a. & n.a. & 0.2 & 4.3 & 2.6 & 2.5 & 2.8 & 2.2 \\
Other & 8.7 & 5.9 & 5.8 & 5.8 & 6.3 & 5.7 & 5.7 & 6.7 \\
\hline
\end{tabular}

Source: 1 IS.

'The compositions are computed for year-end figures of toreign exchange seserves. All numbers are expressed in percentages.

10.3). Indeed, the currency distribution of reserves since 1992 has been relatively constant, with the exception of holdings of Japanese yen (which have declined by 12.8 percent since 1994). It is not easy to draw clear conclusions about a change in the composition of aggregate reserve holdings. Horii (1986) has shown that roughly only 1 percent of the 12.8 percent drop in the U.S. dollar share of reserves between 1972 and 1984 was attributable to a change in the preferred holdings of currencies by central banks. ${ }^{6}$ A much more significant factor was the greater accumulation of non-U.S. dollar currencies by countries with different reserve baskets. Horii also found no evidence that the currency composition of foreign exchange reserves could be explained by international trade patterns or traditional risk and return arguments. It seems that a large part of currency management focuses upon liquidity concerns--hence, unsurprisingly, the large holdings of U.S. dollars.

Finally, a word or two should be said about gold. The estimated 35,000 tons of gold held by central banks (equivalent to about $\$ 430$ billion) still represent a significant proportion of global reserves, despite a steady decline from about 90 percent in 1970 to 20 percent today (see Figure 10.5). The effect on market sentiment of central bank gold sales should not be underestimated, but such sales as have occurred have been modest in comparison with the level of total central bank holdings, and the proportional decline is almost entirely due to the rise in foreign currency reserves.

"See Akinari Horii, "The Evolution of Reserve Currency Diversification." 
Figure 10.5. Gold Share of Central Bank Reserves

(In percent)

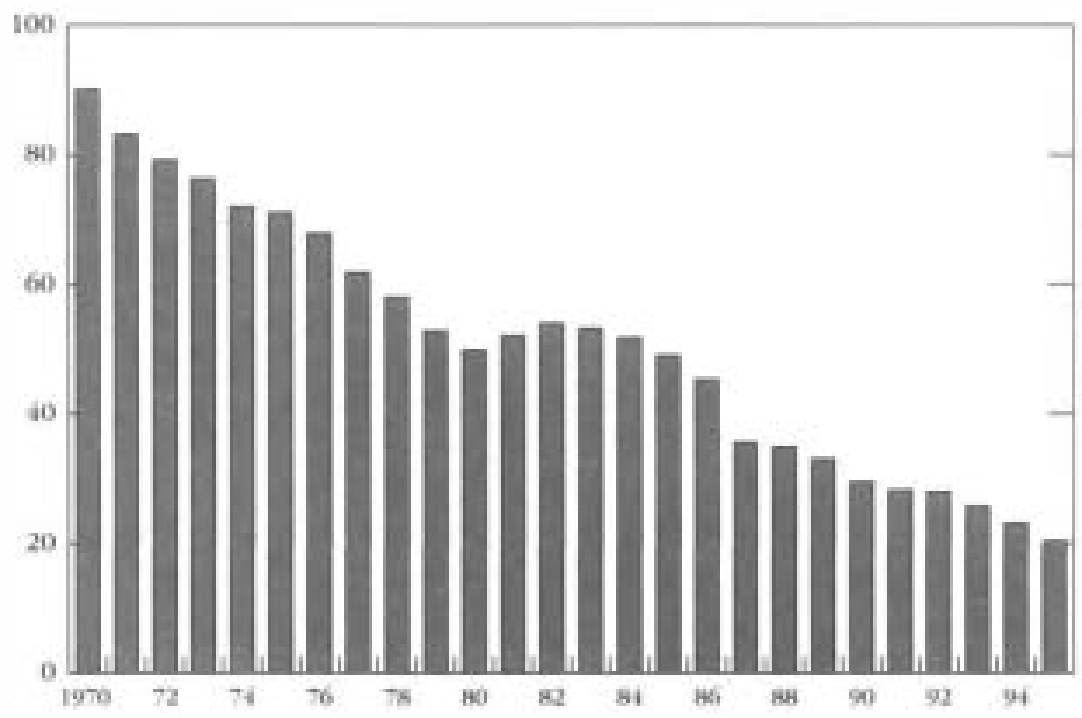

Source: IMF, Internationsl Financial Statistics.

\section{Significant Changes in Objectives and Investment Policies}

The significant developments over recent years in central bank reserves management have been largely prompted by dramatic changes in the external environment, including the internationalization of money and capital markets as well as the impressive advances made in technology and information systems. It is, however, also the result of profound changes that have taken place within central banks themselves, whether arising from increased accountability for their actions demanded by the public, or by the trend toward greater independence, or the significant improvement in communication between central bankers themselves, fostered by international organizations (such as the BIS) and private financial institutions. In many cases, of course, it will be a combination of all these factors.

This section reviews some of the more important changes currently being experienced by central bank reserves managers. 


\section{Progressive Increase in Transparency}

Reserves management has for a long time been considered one of the most confidential activities of central banks, partly because of its links to foreign exchange intervention, but also because of the central banks' own traditions of secrecy. This confidentiality with regard to reserves management is still predominant among central banks. Nevertheless, some changes are emeiging. Regulators have pushed commercial institutions toward more transparency in the presentation of their published accounts. Following the same path, finance ministries and governments increasingly require detailed and sophisticated information from central banks on the management and performance of national reserves. As a price for greater independence, central banks could in the future be subject to demands for more transparency as their accountabilities become more precisely identified. In emerging market economies, such transparency may to a certain extent be imposed by the market - which will require more information before committing substantial funding to a countiy.

At present, a minority of central banks make their investment policies and precise performance figures available to the public (such as Australia and New Zealand) or through a mark-to-market end-of-year balance sheet (such as the Netherlands and Sweden). This trend may be expected to accelerate in the future.

\section{Significant Changes in Definition, Objectives, and Constraints of Reserves Management Policy}

The security and safety objective remains paramount to reserves management in central banks, leading toward a tightening of credit constraints and a better assessment of the risks incurred. Central banks are averse to credit risk, such as exposure to losses through defaults. Even if the losses are eventually recouped through litigation, most central banks do not want the risk of having their names even mentioned in this connection (given the reputation risk and cost involved).

To some extent, as a result of this credit aversion, central banks seem to price credit risk differently from other participants. Over recent years, therefore, few central banks have loosened their credit risk constraints. On the contrary, most of them have moved toward 
tighter rules in response to the perceived weakening of credit ratings among banks and a general tendency toward concentration. More specifically, the trend toward tighter rules will only have been encouraged by various examples of central banks being unwittingly caught up in bank failures. The growth of marketable debt in most developed countries has resulted in a marked increase in the availability of liquid and highly rated government securities, providing central banks with attractive opportunities to diversify and replace bank risk.

The sensitivity of central banks to credit risk is such that there is a clear trend to develop credit risk groups charged with the independent assessment of banking counterparties and even, sometimes, of sovereign entities-with a view to setting limits for transactions. For this credit risk function, central banks are drawing on their own analytical capacity but also, like the market, are using the services of major rating agencies. It is also worth mentioning that, with regard to a specific failure of a financial institution, conflict may arise between the role of a central bank as an investor, on the one hand, and as a regulator on the other.

Liquidity has also remained a major requirement for central banks, and they have noticeably improved and refined their liquidity management. Of course, liquidity remains difficult to grasp and to quantify as there is no precise economic model to analyze it. $\mathrm{Li}$ quidity is relative and often dependent on market conditions. The liquidity premium cannot easily be isolated from the market or credit risk premiums. For central banks, liquidity has another dimension, which is the necessity not to unsettle markets and create financial disturbances that could conflict with other policy obiectives.

As measured by the relative share of securities in foreign exchange reserves (BIS computations show that securities represented 75 percent of central bank foreign exchange reserves in 1995), liquidity has continued to increase in recent years, mainly in relation to the development of liquid securities markets in most of the currencies that are held as reserves. ${ }^{7}$

In addition, it is widely recognized that the dominance of the U.S. dollar in foreign exchange reserves (particularly reserves kept for in-

${ }^{7}$ There is, of course, wide disparity between the liquidity of different securities. 
tervention purposes) can also be partially explained by the role of the dollar as a transaction currency and the liquidity of the U.S. money and capital markets. There have, however, been several changes to the approach of central banks to liquidity management:

- Many central banks have split their reserves between liquidity and investment portfolios in order to deal with different sets of objectives and constraints. Liquidity portfolios usually have a short-term management horizon and duration. The low, but effectively riskless, return achieved on this portfolio is then viewed as the price to pay for liquidity. The key question when managing such a portfolio is more to determine its size than its asset composition (which is usually short-term money market instruments). Some central banks have also recognized that through derivatives they might even, to some extent, split the management of market risk and liquidity risk. For example, through the use of futures, it is possible to hold securities across the curve (which are sometimes more liquid than "current" issues).

- Some progress has been achieved in the qualitative analysis of liquidity by central banks. Most now assess carefully their potential liquidity needs through historical and statistical analysis of past intesventions and, for some, worst-case scenarios or stress tests. Nevertheless, when evaluating the potential need for liquidity, central bank managers also need to adjust their portfolios and take full account of recent developments in the economic, and particularly in the foreign exchange, policies of their countries.

- There has also been some evolution in the approach to liquidity by central banks. This has traditionally consisted of defining liquidity risk as the risk that money cannot be recovered quickly, or recovered only at considerable cost. The ability to sell or to liquidate positions is obviously relative and linked to the depth of the market and its capacity to absorb large trades. Apparently, globalization of financial markets and the extension of hedging possibilities have enhanced the liquidity of most markets. However, there is a growing concern that, due to the concentration of the industıy, the liquidity of some markets would be quite vulnerable to the potential default of a major player. 
- Another approach is to view liquidity risk as arising from funding mismatches in cash flows. In other words, to bear liquidity risk is to run the risk of not being able to meet cash needs or to run the risk of not having funds readily available when required. As compared to the traditional approach (ease of liquidation), this alternative considers that cash needs can be met not only by liquidating assets but also through borrowing outright or against collateral.

- Indeed, the rapid development of repurchase (repo) and swap markets has made it easier for a central bank to borrow foreign currency for a short period of time against its domestic currency, as well as against other kinds of collateral: securities, other foreign currencies, gold, and so on. Some central banks have in addition developed agreements on repo lines with other central banks: this type of agreement has sometimes been concluded between institutions in the same geographical area (such as the recent bilateral U.S. dollar repurchase agreements concluded among a number of Asian countries).

- Nevertheless, liquidity in the sense of financing capacities still remains a relative concept-as the conditions under which funds can be borrowed vary significantly from one debtor to another. Each central bank has to assess its own trade-off between holding securities, which can be easily liquidated, and its borrowing costs. Globally, it seems that liquidity management has become much easier for countries that enjoy a highquality credit rating and are well regarded by financial markets. Others have also benefited from the overall increase in the liquidity of markets, but to a much lesser extent.

- The most noticeable change as regards central bank reserve management objectives is the increasing weight placed on return. Return maximization is still a "tertiary" objective but is playing a steadily increasing role in reserves management. The main reasons for this evolution include the following.

- In many countries, there is increasing pressure from governments to maximize income from reserves to benefit government finances or to service external debt.

- There is a more widespread perception that new financial management techniques provide cost-effective ways of im- 
plementing a conservative management policy and therefore a return-oriented management is no longer contradictory to a conservative management.

- High returns are required as evidence of the prof essionalism of the staff (as good as the private sector) and of the reputation for efficiency of the central bank.

- High returns are necessary to justify and to finance the evergrowing investments needed (staff, IT, back office, and so on).

Although it is dangerous to generalize, it seems that the emphasis on return is often linked to the size of the reserves; the higher the level of reserves, the more weight attached to achieving a higher return. This is consistent with the idea that central banks seek first to meet their transaction and intervention needs, only then turning to the goal of maximizing returns. It is also consistent with general economic and financial theory, which assumes that the richer an investor is, the less risk averse he or she is.

The increasing appetite for return puts more emphasis on the formulation of a precise return objective. Most central banks claim that their objective is to achieve a "reasonable," "satisfactory," or "optimal" return. However, central banks have different attitudes toward this question. Given the uncertainty of their investment horizon and of their currency allocation, most of them set relative return objectives versus a benchmark. A few of them define a minimum total return objective at the start of each new financial year, specifying the reference currency (which could be the domestic currency, a specific foreign currency, or a currency basket) and a reference currency allocation.

\section{Increased Appetite for Return Has Led to More Active Management}

The tremendous improvements in communication and technology have helped markets to become much more efficient: mispricings, arbitrage opportunities, and "anomaly trading" have more or less disappeared or at least have become so limited in time and in size that they require leveraged positions to take advantage of them. Figure 10.6, prepared by J.P. Morgan, shows indeed a significant reduction in the magnitude of term-structure "errors" in the main gov-

\section{CInternational Monetary Fund. Not for Redistribution}


Figure 10.6. Tighter Term Structures

(In basispoints)

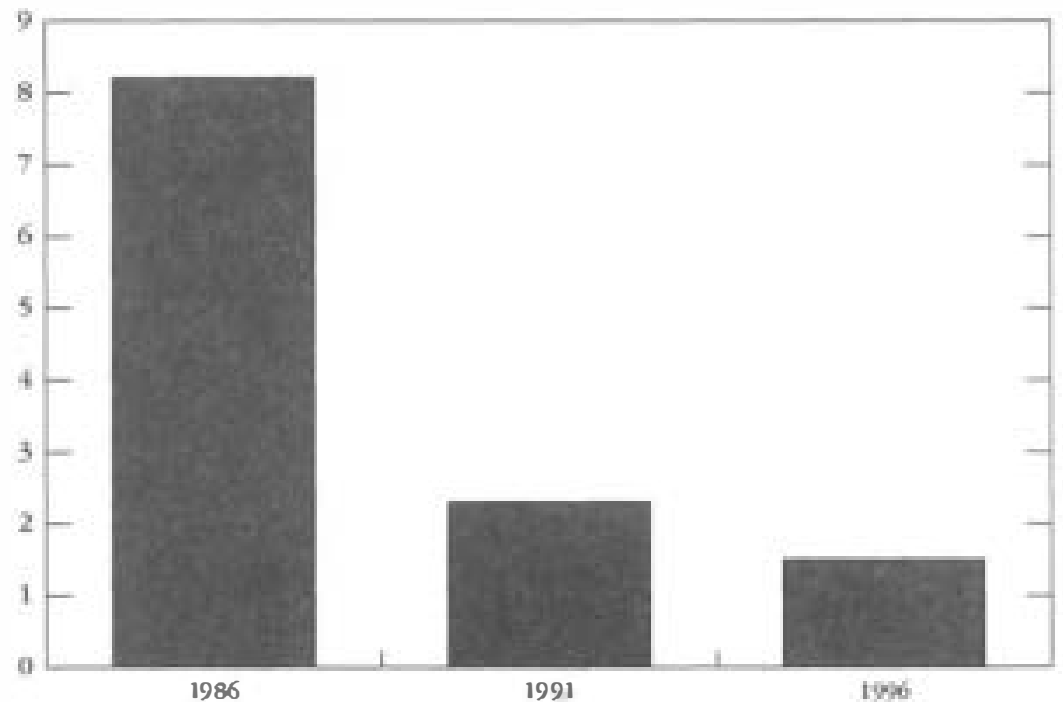

Source: National sources.

Note: Average standard error in regressing claity changes seven-year government yield on 2-. 5-, and 10-year henchmarks in the United States, United Kingdom, Japan, Germany, and France during the first six months of the year.

ernment bond markets (in the example, over 10 years, the average difference between the 7-year government bond yield and its theoretical value as calculated by a term-structure model based on 2year, 5-year, and 10-year bonds declined substantialiy). In other words, central banks can no longer rely mainly on traditional and relatively riskless arbitrage, an activity on which most of them originally built their reserves management capacities.

Many central banks have since moved toward a more active management of their interest rate risk and, less frequently, of their foreign exchange risk. Most of them actively manage the duration of their portfolios in tight limits to increase relative return versus a benchmark that represents passive management: over recent years, central banks have become major players in short- and mediumterm securities of the principal G-10 government and money mar- 
kets. In response to this devclopment, a large number of private financial institutions have over the years created specialized central bank desks, and they devote significant efforts to providing information and training to central bank staff. ${ }^{8}$

Only a few central banks actively manage their currency risk. The size of their foreign exchange positions is, however, of ten limited.

Finally, to increase their return, most central banks have partly eased the constraints on the maximum authorized maturity of investment products and on the type of instruments permitted. However, both diversification and maturity-lengthening remain limited for the present.

\section{Performance Measurement and Risk Assessment}

Benchmarks have become the norm as regards internal performance assessment of reserves management. Indeed, they present many advantages: as a means of communication and control across the whole organization; as an expression of risk preferences; as a means of the long-term investment policy of the management and the board; as a market-neutral position; and as an objective for portfolio managers. Over recent years, many central banks have found it useful to use such technigues, if only to revisit and increase the consistency of their reserves management policies.

However, many central banks still have a traditional costaccounting approach for publishing their results. The inconsistency of this with the benchmark "total rate of return" approach remains limited-provided the average duration of the portfolio is kept rather short (up to one year). There is much more of a problem when funds are invested in the longer part of the yield curve, where capital gains and losses can often be significant. Both solutions have drawbacks: mark-to-market accounting can create a higher volatility in the yearly profit-and-loss accounts owing to market fluctuations (this sort of volatility is usually regarded as counterproductive for the central bank); book cost-accounting, on the other hand, can create profits and losses that are not directly related to market movements. It can even sometimes interfere with the management of the portfolio when it contains large potential losses.

8some of the central bank desks have recruited former central bank reserves managers. 
Benchmarks are usually rather short (from three months to two years) for two main reasons. One reason is that, owing to the specific purposes of reserve assets (they could be unexpectedly required for interventions), central banks cannot always assume they will keep the same amount of funds over a full interest cycle: the usual risk/return analysis, which in efficient markets would argue for a long duration, cannot simply be applied to central bank reserve management. Another reason is that being conservative investors, central banks keep their investments short to avoid a negative total return even on short periods-though, over recent years, there has been a modest lengthening due to an increased appetite for return. As mentioned earlier, only a few central banks actively manage foreign exchange risk, so global benchmarks are the exception, and most central banks have different benchmarks for each cuirency.

Considerable efforts have been made by central banks in defining appropriate benchmarks. Many central banks have developed internal, sometimes sophisticated, benchmarks, which they maintain and improve constantly. But there has also been a recent trend toward using extemal benchmarks, which can be viewed as providing more credibility to the investment and performance measurement process. More important, the availability, the range of countries, markets, and market segments covered by external indices and subindices have considerably increased-allowing central banks to combine them easily in a way that best suits their needs.

There is nevertheless a risk in focusing excessively on the benchmark as shown by the 1994 bond markets sell-off. A sharp increase in market volatility and adverse movement in interest rates could indeed lead to a significant and unexpected negative return. Many central banks have come to realize the shortcomings of this approach and also of their traditional risk measurement, which generally was based on duration analysis. Hence, the welcome given by central bank reserve managers to the rapid development of new risk management techniques.

Indeed, central banks have shown great interest in these new techniques and in the concept of value-at-risk (VAR), in particular. Among factors of note here has been a progressive recognition by central banks that financial risks are an integral part of their core business activities (not only for reserve management, but in other areas such as the application of monetary policy as well). Some of 
them are therefore keen to use the most recent and sophisticated techniques to measure their financial risks. There has also been substantial progress in information technology and the availability to a large investor base of pre-computed standard risk data (particularly through J.P. Morgan's RiskMetrics set of correlations and volatilities), which has made the task of measuring these financial risks much easier. In addition, central banks are usually thoroughly involved or are responsible for the supervision of their domestic banking system.s. A deep, theoretical, and practical understanding of financial risks is regarded today as essential in carrying out this task. ${ }^{9}$

A few central banks are already using VAR or similar concepts at an operational level to define their risks and objectives more accurately. Many others are considering it. This process is only in its early phases. It remains to be seen if these techniques, which could lead to substantial changes in the management of funds, will be accepted and adopted at higher management levels within central banks.

\section{Increased Use of External Portfolio Managers ${ }^{10}$}

Over recent years, many central banks have entrusted one or more external asset management companies with a modest part of their reserves. They do so for a variety of motives, including the fact that the use of external portfolio managers allows them to invest indirectly in certain markets where it would be difficult to be active directly. either for time zone reasons or because they lack the required expertise. External portfolio managers are often used as yardsticks for comparisons with risks and returns achieved internally, even if the guidelines established are often quite different from internal ones. The major reasons for using external managers, however, lies in the desire of central banks to benefit from more specialized and different skills in portfolio management. An external portfolio manager usually offers comprehensive systems for risk

In the proposals of the Basle Committee on Banking Supervision to amend the 1988 Capital Accord to incorporate market risk, regulators have accepted that banks could use their internal models of VAR to measure and report their market risk, subject to a number of carefully defmed conditions.

10On this topic, see John Nugée, "Use of External Managers in Central Bank Reserves Management." 
and performance measurement, training facilities, market research, and, more importantly, the opportunity to profit from an ongoing dialogue about fund management with a firm using private sector investment knowledge and style.

A minority of central banks have pushed this reasoning further: whether for lack of internal resources, the conviction that the private sector can perform as well as internal managers at a competitive price, or else the willingness to foster a local fund management industry, some institutions (such as the Hong Kong Monetary Authority and the Central Bank of Argentina) have decided to entrust a larger part of their funds for management by the private sector.

Striking evidence of the importance attached to external portfolio management by certain central banks is the ever-more elaborate process for selecting external managers. If public tenders for external portfolio managers are still the exception in the world of central banks, the information required has become comprehensive. ${ }^{11}$ In some cases, use is made of specialized external consultants to assist the central bank in its selection process.

Despite some disappointment about actual experience on performance, particularly when markets are performing badly (for example in 1994), this trend is expected to continue. It should be stressed in conclusion, however, that many central banks have found that "managing" an external portfolio manager can sometimes prove as demanding and time-consuming as managing the funds for themselves directly.

\section{Evolution of the Use of Derivatives}

While many institutions remain cautious, other central banks have increased their use of derivatives for reserves management purposes, considering these instruments as an additional tool to manage their portfolio rather than a specific asset class. Studies on de-

IUsually, a potential candidate for managing a portfolio on behalf of a central bank has to provide a complete file detailing the track record, the customer base, the size of fund under management, the management phitosophy, the fee structure, the qualifications of the staff, the tumover in the staff, the staff compensation system, the projected lime spent on the central bank account, the projected time spent on research, the training provided, the performance objectives, the decision-making process, and so on. 
rivatives conducted in the early 1990s by individual central banks or by specific groups have certainly contributed to this progressive change of attitude. ${ }^{12}$

Two factors in particular have encouraged this development:

- On the asset side, the futures markets have rapidly come to be used as a cheaper way than cash securities trading to manage the duration of portfolios (this is particularly evident for the Bund market).

- From early on, those central banks responsible for managing liabilities have, like other borrowers, made extensive use of interest rate and currency swaps for issuing debt in the most appropriate currencies or markets, and adjusting the risk characteristics of their porfolio.

Further development in the use of derivatives has gone hand in hand with progress achieved in the level of expertise of both staff and management, the quality of risk controls, and the development of IT systems to monitor and process derivatives transactions just as it has with the majority of institutional investors.

At present, central banks are mostly using straighoforward, linear products such as futures, forwards, short, and medium-term currency and interest rate swaps (often referred to as "first generation" derivatives). Sophisticated structured products, which were extensively marketed to central banks in the early 1990s, have seen a declining interest owing to their lack of liquidity and transparencyand perhaps also to the increased capacity of central banks to adjust their risk profiles themselves by using common (plain vanilla) derivatives. This said, the major leap forward in the use of derivatives has occurred in the options market: the features specific to options (asymmetry and nonlinearity) make them a genuinely different class of product that would allow the implementation of new investment strategies and perhaps further lead to a more radical overhaul of investment policies. On the other hand, due to these characteristics, options are more difficult to price, process, and monitor, and the risk assessment is more complex.

${ }^{12}$ In this respect, the report of the G-10 working group chaired by Mr. Hannoun, Deputy Governor of the Banque de France, which addressed macroeconomic and monetary policy issues raised by derivatives markets, played a significant role. 
At present, few central banks are using options for intervention purposes. ${ }^{13}$ However, there is a growing number using them for portfolio management purposes, such as foreign exchange options, interest rate, or bond options and even in some cases "exotic options" (such as barrier options) but in limited amounts. This development will certainly continue although the ever-increasing complexity of derivatives markets clearly acts as a brake to their use in central bank reserves management.

\section{Factors Liable to Slow These Trends}

The recent developments in reserves management outlined above, and in particular the increased focus on the wealth-accumulation function, may slow down in the coming years. Three significant elements could indeed stand against or in some limited cases even reverse this evolution: the impossibility for a large number of central banks to manage gold as a day-to-day asset; the increase in the mobility of international capital flows; and the difficulties of operating market activities in public sector institutions.

\section{Central Banks Will Have Little Opportunity to Manage Gold Reserves Actively With a View to Maximizing Return}

Gold over recent years has not represented a profitable investment for central banks. Figure 10.7 shows the excess returns obtainable by investing in one-year treasury bills rather than gold. ${ }^{14}$ The annualized return over the entire period from 1978 to 1995 is 8.6 percent for the one-year bills, 4.84 percent for gold (price returns), and 5.87 percent for gold (including price and lease rate terms with a 1 percent annual lease rate). Not only has the gold price deteriorated significantly, from its heady $\$ 800$ per ounce highs to below $\$ \mathbf{4 0 0}$, but the yields available to those institutions who

\footnotetext{
13In practice, one of the most powerful arguments against this idea is that the signal sent to the market by a central bank intervening in options is less clear to market participants than the one sent through a direct intervention in the spot market (connected to a clear exchange rate level).

${ }_{14}^{1}$ The returns for gold are based on yearly price changes and do not include revenues from leasing gold.
} 
Figure 10.7. Excess Returns of U.S. Twelve-Month LIBID Over Gold (n percent)

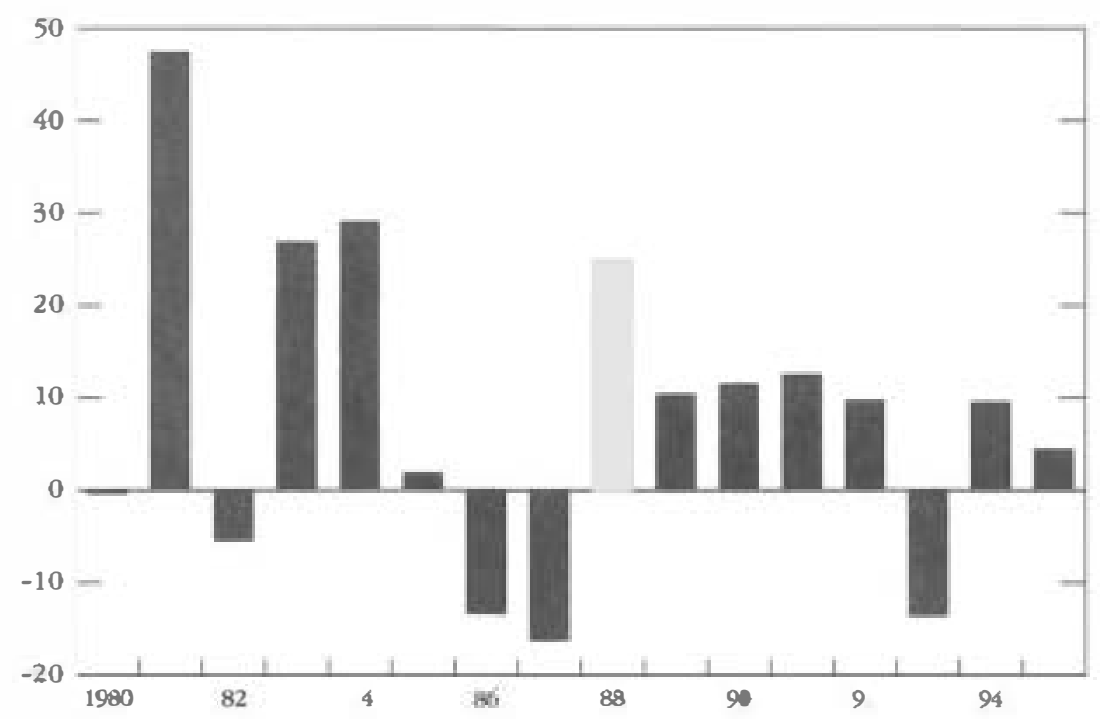

Source: Autlior's calculations.

lend their gold into the limited deposit market have been relatively poor in comparison to other high-grade investment outlets. The more recent decline in the price of gold, traditionally held by investors as an inflation hedge, can be partly explained by the relatively high level of real interest rates and indeed the general fall in inflation expectations. The unresolved debate about possible IMF sales, the continuing forward sales by mining companies, and the uncertain ramifications of EMU have also recently been weighing on the market.

Nevertheless, many major central banks still see gold as a guarantee of central bank credibility and a symbol of stability. It is also regarded as the ultimate prudential asset, a source of liquidity of last resort, and as such there has been a certain reluctance to mobilize gold holdings. A rise in gold deposit yields in the mid-1990s, a byproduct of forward sales by gold producers, has pushed a substantial number of central banks to place some of their gold assets on the lease market (whose size is estimated at between 2,500 tons to 3,000 tons). However, the possibility of any part of the remaining 
32,500 tons of official gold coming onto the market could be enough to put a cap on gold yields.

\section{Increase in the Mobility of International Capital Flows}

The world economy is becoming increasingly more integrated as convertibility gains ground in emerging market economies. This has been evidenced by an increase in capital flows between countries, especially from industrialized to emerging market economies. For example, between 1991 and 1995, the average annual capital inflows to Asian and Latin American countries was estimated at $\$ 69.88$ billion. This was much higher than averages for previous years, which were in the order of about $\$ 12.4$ billion a year. ${ }^{15}$

As a result, any country, whether industrialized or developing, could experience large and sometimes abrupt capital inflows and outflows. In such a global market, every objective or policy regarding reserves management is superseded by the pressing demand for liquidity.

As for emerging market economies facing large inflows of capital, particularly portfolio inflows, extra care is needed in managing reserves and maintaining substantial buffer stocks to react quickly. The Mexican crisis of 1994 offers a stern warning in this respect: most of the capital inflows, which had represented on average 6.8 percent of GDP from 1990 to 1994 , left the country in less than a month (December 1994), prompting a dramatic depreciation. This had a spillover effect in some Latin American and Asian countries (the so-called "tequila effect") and triggered substantial capital outflows that required some of these countries to intervene heavily. ${ }^{16}$

Countries maintaining a fixed or semi-fixed exchange rate target should be aware that the size of international markets and the mobility of capital is such that massive interventions could be needed over a short period to resist speculative attacks. The 1992 ERM crisis in this respect is a particularly telling example. According to a

15 See BIS Annual Report, June 1996.

16 On this point, some economists have suggested that temporary controls or taxes on capital inflows may in some circumstances provide helpful protection against intemational financial turmoil (based on the experience of Chile and Colombia). See Michael Gavin and others, "The Macroeconomics of Capital Flows to Iatin America: Experience and Policy Issues," in Hausmann and RojasSuárez. 
G-10 report prepared in 1993, some DM 284 billion (nearly 20 percent of worldwide foreign exchange reserves at that time) were sold in the markets by European central banks (including those of the Nordic countries) between June and December without preventing a partial collapse of the system. ${ }^{17}$

The case for countries maintaining a floating exchange rate target is not much better. While it is true that such countries may not face a speculative attack as traditionally defined, there is still the possibility that an exchange rate may suffer large swings-unwelcome to the central bank. The latter may want to dampen this volatility, particularly to prevent the exchange rate from reaching certain "trigger" points. This may require substantial foreign exchange interventions as well. The magnitude of international capital flows imposes on central banks the need to maintain, and even in some cases to tighten, their liquidity criteria.

\section{Difficulty of Operating Market Activities in Public Sector Institutions}

Operating market activities in public sector institutions such as central banks poses specific problems. Some of these are related to the nature of the decision-making process and human resources management within central banks. Other problems arise owing to the difficulties faced by such institutions in making the necessary investments required to keep up with the rapid development of financial markets.

As mentioned earlier, the management of foreign exchange reserves is a sensitive issue for central banks, since market participants scrutinize and attach great importance to any central bank market activity and might therefore misinterpret reserves management transactions. ${ }^{18}$ However, foreign exchange reserves management may sometimes seem a subsidiary activity for central banks in comparison with monetary policy issues, which are its primary responsibility. Moreover, the prevailing culture in central banks may

${ }^{17}$ See "International Capital Movements and Foreign Exchange Markets."

${ }^{18}$ This is even more important since in market economies, credibility and reputation have become the main instruments of central bank monetary policy. 
be far less profit-oriented and money-driven than in the private sector.

In many central banks, there may be a conflict between their specif ic needs for recruiting specialized and experienced portfolio managers and their general hiring policy aimed at recruiting generalists. Moreover, as public institutions, central banks cannot compete effectively with the salaries offered by private institutions for premium talent. Central banks can end up losing staff to the private sector. which can be disruptive to their small portfolio management teams. It needs to be emphasized that central banks need professional staff who can manage reserves well but their role is different from that of a private sector fund manager. The qualities needed by the central bank reserve manager are not necessarily the same as those in the private sector.

The cost of technical infrastructures and human resources that would be incurred in keeping pace with the market has increased tremendously in recent times. Indeed, markets are more efficient. technology has been changing rapiclly, and the markets are dominated by large players that can make substantial investments in technology. It is difficult for central banks to make similar investments in technology owing to institutional constraints, a lack of customers to whom they can pass on the costs, less clear risk/return goals, and the instability of foreign exchange reserves. For this reason, central banks run the risk that many miclsized institutions face- - of falling behind in terms of technology.

\section{Conclusions}

This paper has discussed many of the issues regarding foreign exchange reserves and their relationship to a changing world economy. In particular, it has been noted that the recent growth in world reserves has been more rapid than in the past, though the currency composition of reserves has remained relatively stable. Some of the recent changes in central bank management of reserves have also been documented. Although liquidity is still the central issue for foreign exchange management, return maximization is becoming a more important concern. The future evolution of foreign exchange reserves may prove to be much more complicated. In the final part of this paper, a few of the potential complications were touched 
upon, such as the management of gold reserves, the increased mobility of capital, and the difficulties of managing market activities in public institutions. However, there may be yet another: the creation of the euro. What will be the evolution of a new European currency with respect to other world currencies? Will it bring a halt to the strong growth in foreign exchange reserves-taking into consideration the fact that a European central bank might need less foreign exchange reserves for the purpose of trade or current account stabilization? To what extent will the euro challenge the dollar as the dominant world currency?

Despite these questions, it is hard to imagine that the considerable development of the management of foreign exchange reserves observed in recent years could substantially reverse its course. However, managing reserves will never be identical to private fund management and will continue to reflect for a large part the macroeconomic objectives and constraints of individual countries.

\section{References}

Bank for International Settlements, 1996, "Central Bank Survey of Foreign Exchange and Derivatives Market Activity $1995^{*}$ (Basle: Bank for International Settlements, Monetary and Economic Dept.).

, 1996, BIS Annual Report (Basle: Bank for International Settlements).

Gavin, Michael, and others, 1996, "The Macroeconomics of Capital Flows to Latin Anerica: Experience and Policy Issues," in Banking Crises in Latin America, edited by Ricardo Hausmann and Liliana Rojas-Suárez (Washington: Inter-American Development Bank; distributed by Johns Hopkins University Press).

Goldstein, Morris, and Philip Turner, 1996, "Banking Crisis in Emerging Economies: Origins and Policy Options," BIS Economic Paper No. 46 (Basle: Bank for International Settlements, Monetary and Economics Dept.).

Group of Ten, Group of Deputies, 1993, "International Capital Movements and Foreign Exchange Markets: A Report to the Ministers and Governors" (Rome).

Hong Kong Monetaty Authority, various issues, Quarterly Bulletin (Hong Kong: Hong Kong Monetary Authority).

Horii, Akinari, 1986, "The Evolution of Reserve Currency Diversification," BIS Economic Paper No. 18 (Basle: Bank for International Settlements, Monetary and Economic Dept.). 
Nugée, John, "Use of External Managers in Central Bank Reserves Management," euarterly Bulletin (Hong Kong: Hong Kong Monetary Authority).

Roger, Scott, 1993, "The Management of Foreign Exchange Reserves," BIS Economic Paper No. 38 (Basle: Bank for International Settlements, Monetary and Economic Dept.). 


\section{1}

\section{Reserves Management Operations in Australia}

\section{Rick Battellino}

$\mathrm{B}$ efore I outline the details of reserves management operations in Australia, I should explain the reason why we hold reserves, which is essentially to fund foreign exchange intervention. The Australian dollar typically follows a regular cycle, rising during periods of strong world economic activity and declining when world activity softens. As often happens in markets, the exchange rate tends to overshoot at the peaks and troughs, and we have tended to intervene at these times to try to moderate the overshooting.

Reserves are not held for the purpose of providing a store of wealth, and we therefore have not sought to build reserve holdings rapidly over time. We hold what we think we need for intervention purposes and to that extent our holdings have, typically, not been large by Asian standards. International reserves are held on the Reserve Bank's balance sheet and are managed exclusively by the bank.

In this paper, I shall start by outlining Australia's objectives in reserves management. I will then say something about the benchmarks we have developed, how we manage risk, how we measure performance, and the systems we have, and then conclude with just a few observations about our experiences.

\section{Objectives}

At the stast of the 1990s, the Reserve Bank undertook a major review of reserves management arrangements. The process of change 
had in fact started soon after we floated the exchange rate in 1983. Prior to that, the bank had to clear the foreign exchange market each day, as there was a fixed exchange rate. The ultimate objective of reserves management at the time was to have liquidity available-because we never knew how much foreign exchange we would need on any particular day. Once we floated, of course, intervention was at the Bank's discretion so we could feel more relaxed.

The float did not immediately lead to a change in reserves management arrangements because soon after we floated, reserves fell to quite a low level, which meant that liquidity was still regarded as important. As the 1980s went on, reserves built up to quite comfortable levels, and we were therefore able to start thinking about how we could invest them more profitably. We were also conscious that fund management techniques in the private sector and among other central banks were evolving quickly, and there was an onus on the bank to keep pace in its own operations. At the same time, the community debate was focusing more on central bank accountability, and we were conscious that we needed to be able to satisfy the public that the bank was doing a good job in managing the country's official foreign assets.

As part of our review, we decided on the following benchmark. In doing so, we went through a number of steps, starting with the usual technical analysis, but there was also a lot of "judgment" in the final result. In some ways, this concurs with the view put in another paper that most of the benefit in undertaking benchmark analysis comes from actually having to put on the table one's thinking about the objectives-and how much risk one is prepared to accept.

The change in the currency composition of Australia's reserves since the float can be seen in Figure 11.1. When we floated, we basically held U.S. dollars with some minor amounts of Japanese yen and European currencies. But now, there is a much more even distribution among the three major reserve currencies.

We included the three major reserve currencies in the benchmark as these all offer deep asset markets, but we felt there was little net benefit in going beyond these. One reason for having sizable holdings of yen and marks in the benchmark is that these currencies display a strong negative covariance with the Australian dollar. The Australian dollar is closely linked to the U.S. dollar, and given that 
Figure 11.1. Currency Composition of Official Reserve Assets (In percent)

December 1983

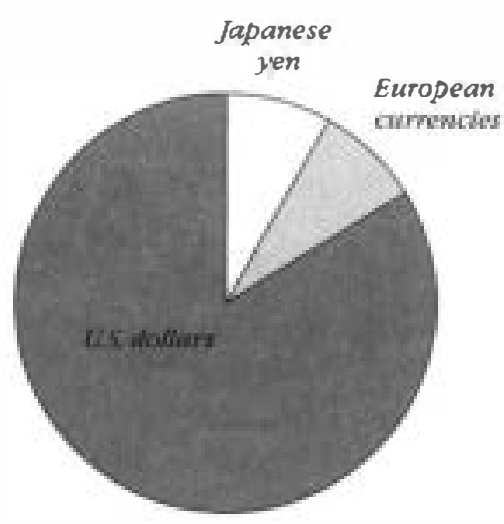

October 1996

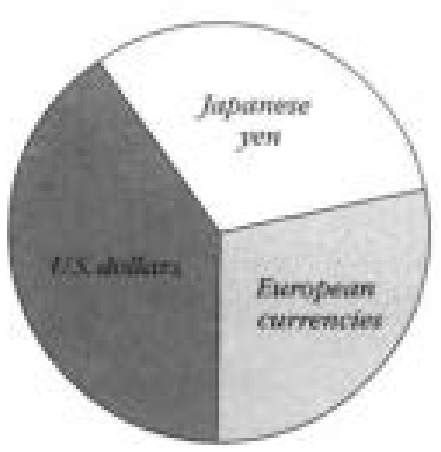

Source: National sources.

we would want to draw on reserves at times when the Australian dollar was weak, it would be likely that the U.S. dollar would also be weak at those same times. That is, at the very time when we wanted to sell U.S. dollars to support the domestic currency, they would be worth their least, whereas holdings of yen and marks are likely to be worth more at these times.

Among other characteristics of the benchmark, the middle of the table reveals the duration of the benchmark (about 30 months for all the portfolios in late 1996). Initially, we had a shorter duration for the U.S. portfolio because the U.S. dollar is the intervention currency, but as time went on, it became clear that we did not need a short U.S. duration because the growth of repo markets and the forward foreign exchange markets (or currency swap markets) means that intervention can be funded in the short run through these means. That is, if we sell U.S. dollars for intervention purposes, we do not need to go out immediately and liquidate U.S. Treasuries to fund it; we can repo Treasuries instead. The development of these markets made it easier to move out along the curve and earn extra return while still maintaining plenty of liquidity.

At the bottom of Table 11.1, you can see the composition between portfolio deposits and bills, repos and bonds. We tend to 
Table 11.1. Composition of Benchmark

\begin{tabular}{|c|c|c|c|}
\hline & U.S. Dollars & Japanese Yen & Deutsche Mark \\
\hline Currency/asset weighting & 40 percent & 30 percent & 30 percent \\
\hline Duration & 30 months & 30 months & 30 months \\
\hline \multicolumn{4}{|l|}{ Asset composition } \\
\hline Deposits/RPs & 20 percent & 20 percent & 4 percent \\
\hline Bills & 20 percent & 30 percent & $\ldots$ \\
\hline Notes/bonds & 60 percent & 50 percent & 60 percent \\
\hline
\end{tabular}

hold few bank deposits. In fact, we try to avoid credit risk as much as possible.

There are several reasons why we settled on a benchmark duration of 30 months. One of our objectives was to avoid negative returns. When we looked at the returns available out along the yield curve, and the variability on those returns, it became clear that once we moved out much beyond two and a half years, the risks of negative returns increased quite substantially. This can be seen in Figure 11.2. The solid line in the middle shows the annual returns that have been achieved on U.S. Treasuries of different durations, measured over a five-year period. The two dotted lines show the 95 percent confidence levels of those returns. For durations longer than two and a half years, the bottom dotted line moves below the zero axis, indicating a rising probability of negative returns.

\section{Trading Around the Benchmark}

In terms of trading, we have a reasonable amount of discretion around the benchmark. I will examine the investment process in more detail later, but in broad terms, most investment decisions are made by an investment committee in the International Department. This committee has discretion to move 20 percentage points either side of the benchmark for currency and asset allocation. That sounds like quite a lot, but it is useful to have this discretion for defensive reasons. In particular, there are situations where the markets have clearly overshot where one would not want to be at the benchmark any more.

For example, when the yen appreciated sharply against the U.S. dollar in 1995, there were risks in holding a large amount of yen. It was obvious that the currency had appreciated too far and eventu- 
Figure 11.2. U.S. Portfolio Returns

(Twelze-month borizon, in percent)

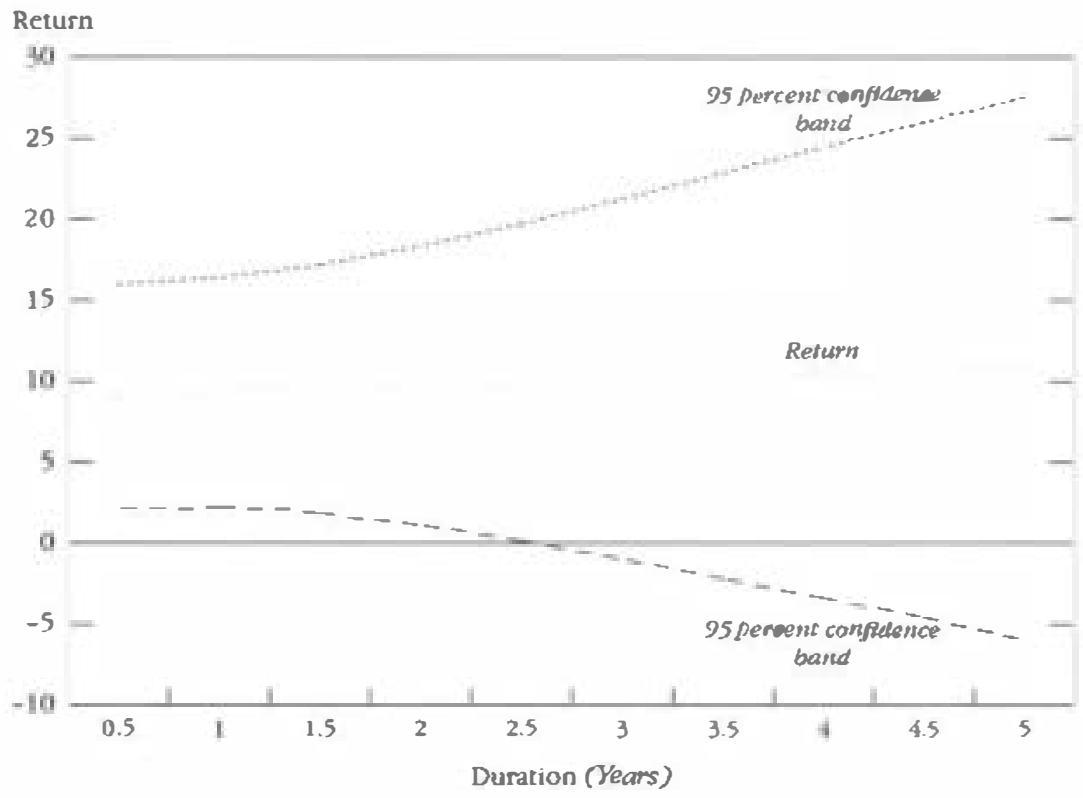

Source: Authos's calculations.

ally it was going to come back. Similarly, on duration and asset allocation, there can be times when the assets are so overvalued that you just do not want to stay at the benchmark. It is important to have scope to be able to manage risks so as to reduce the possibility of negative returns.

The duration of the postfolio is managed in a range of up to 36 months. Initially, we used to go only six months short of the benchmark - with a duration range of 24 months to 36 months. But when we started to use derivatives (interest rate futures) to hedge risks, there was scope to run shorter duration. Again, this is done for defensive reasons.

It is useful to have discretion to manage asset allocation around the benchmark because there is a considerable variation in returns around the world. Figure 11.3 illustrates this. The bars at the top show the difference for each year between the bond return in the country with the highest return and the return in the country with the lowest return, revealing some big differences. For example, in 
Figure 11.3. Variations in Bond Market Returns of G-7 Countries (Inpercent)
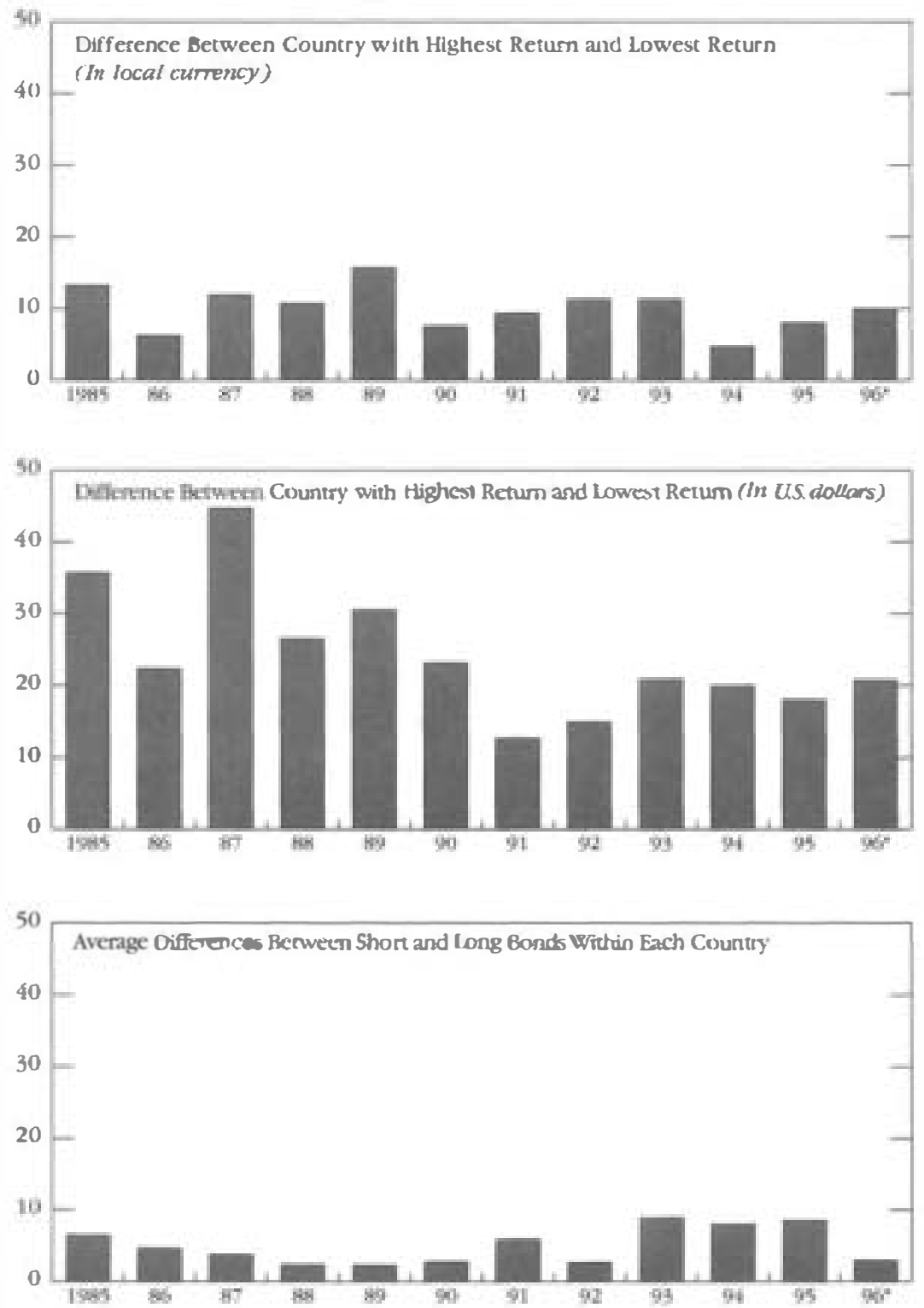

Source: Author's calculations

"Note: G-7 countries (excluding ltaly). Data for 1996 through October 
1985, there was a 13-percentage-point or 14-percentage-point difference between the country with the highest return and that with the lowest return. Differences are even more pronounced when one takes into account currency movements, as can be seen in the second set of bars. By contrast, within each country, the average difference between a short bond and a long bond is small. That is, differences in the performance of asset markets across countries are much bigger than differences in the performance of different bonds in the same country, and the risk arising from this needs to be managed.

The guidelines on duration, currency composition, and asset composition control the total amount of risk we can take relative to the benchmark.

\section{Organization and Systems}

In terms of organizational structure for reserves management, the Governor sets the benchmarks and trading limits, and then delegates management to the International Department (see Figure 11.4). That department has four sections to it: an analytical support group, which does macroeconomic and market analysis; the investment section, which implements the investment strategy, coordinating the operations of the dealing desks, including those in London and New York, which are responsible for investment of the European and U.S. portfolios, respectively (Japanese investments are handled directly from Sydney); a risk management section, which monitors the portfolio against limits and marks to market each day; and the back office section. The offshore dealing centers are linked back to Sydney using direct lines, so they are on-line 24 hours a day.

The Investment Committee is the main decision-making body. This structure ensures that senior officers of the department are involved in undertaking the major strategic positions. The committee meets once a week to consider the broad investment strategy. It considers market and economic developments over the week, but always tries to put all this in a longer-run context. Its decisions are then passed through the dealing centers for implementation. These centers also have a small amount of discretion on duration management and curve positioning, and they undertake anomaly trading, stock lending, repo activity, and so on. 
Figure 11.4. Organization of Reserves Management

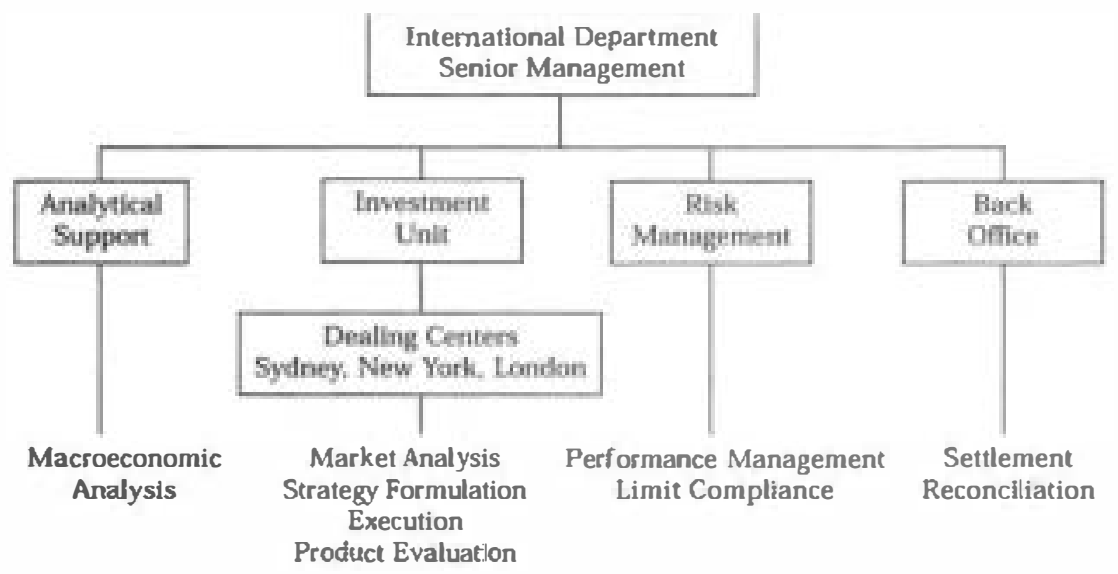

To measure performance, the portfolio is marked to market daily. We also measure the impact of all the decisions that were taken, such as currency and asset allocation-and, within each portfolio, duration, curve positions, and the contributions of the dealing desks. It is important that performance of all of those who have discretion to make decisions be measured to see how they have performed in their decision making, so that we know where our main profit is coming from and whether we are doing consistently well in one area and not in another.

In terms of reporting, we report to the Governors every quarter, and we report to the public in the Annual Report each year as well. We give a detailed rundown of our results for the year, how they compare with the benchmark, and what our major investment strategies were. The surprising thing is that after reporting publicly for five years, our operations had never been a major issue among financial commentators. Nonetheless, all the information is in the Annual Report, and readily available for anyone who wants to analyze it.

Finally, let me say something about our systems. When we started upgrading our reserves management processes, the back office in particular was in need of attention. We had about 25 people in the 
back office and they were always working a great deal of overtime. To address this, we bought an "off-the-shelf" system, which we thought was going to do everything we wanted. But, of course, it did not do nearly as much as we thought it would, and we have had to undertake a fair amount of development work ourselves.

The system now is effective for all the back office and accounting functions. On the front office side, however, it has never lived up to expectations. To handle front office needs, we use the back oftice system essentially as a database, with the PC-based systems feeding off it. Because the reserves management system is always evolving, there are advantages in having the PC-based technology, as it avoids having to wait for outside suppliers to reprogram systems; internally developed $\mathrm{PC}$-based systems can be adapted much quicker.

The back of fice system is linked to the Society for Worldwide Interbank Financial Telecommunications (SWIFT), so that payments are handled automatically. The process is as follows: when dealers undertake a deal, they immediately input it into the computer system, where it shows up in the back office; the back office then confirms it with the counterparty and when they are satisfied that everything is in order, they press a button and the payment goes off through the SWIFT system with no rekeying. This has allowed for big staff savings in the back office

\section{Some Experiences}

Finally, let me finish by outlining our main experiences with the changed reserves management arrangements. The new arrangements have been in place for more than six years now. One of the things we have found is that just undertaking the review was a worthwhile thing in itself. This is because it forced us "to put everything on the table," and we sorted out in our own minds what our objectives were, what our risk tolerances were. and so on. The other thing we have found is that the reserves management operation has some positive spin-offs for our main function at the bankmonetary policy. These days, because so much of monetary policy work involves interacting with markets, central banks need to be able to jucige how markets are going to react to policies and how to read markets. There is no doubt that being in touch with the mar- 
kets continuously through reserves management actually makes that job easier.

Overall, we have been pleased with the outcome of our changes to reserves management. We have found that we have been able to add some value over the benchmark on average. It has also been good in terms of improving our own knowledge of markets and in helping us to keep good staff. Within the bank, the reserves management area is regarded as one of the prime areas to work in, so this helps to attract good staff and to keep staff motivated. 


\title{
12
}

\section{Foreign Borrowing by the Kingdom of Denmark}

\author{
Ib Hansen
}

\section{General Framework}

The main objective of Danish net borrowing in foreign currencies is to ensure adequate foreign exchange reserves. When the Kingdom of Denmark issues foreign debt, the proceeds of the transaction are sold to Danmarks Nationalbank (central bank) and the corresponding amount in Danish kroner is credited to the government's account with Danmarks Nationalbank. Similarly, funds needed by the Kingdom of Denmark for redemptions are bought from Danmarks Nationalbank with a corresponding debit of the government's account with the central bank (in Danish kroner).

The annual net foreign borrowing by the Kingdom of Denmark is determined by the norm for foreign borrowing, which is part of the central government borrowing norm-itself an agreement between the government and Danmarks Nationalbank (see Box 12.1). The norm for foreign borrowing implies that redemptions on foreign debt should be matched by foreign borrowing.

The norm for foreign borrowing may be departed from, however, should foreign exchange reserves be depleted owing to Danmarks Nationalbank's intervention in favor of the Danish krone. Should this happen, foreign borrowing may exceed redemptions on the foreign debt falling due that year. On the other hand, if interventions by the central bank lead to larger foreign exchange reserves than is considered to be necessary, it may be decided not to fully refinance all redemptions falling due. However, the balance on the government's account with Danmarks Nationalbank should always be positive. 
In recent years, the foreign debt has been reduced significantly (see Table 12.1), but by 1996, further reduction was not expected in view of cash flows projected for the central government's account with Danınarks Nationalbank.

\section{Borrowing in 1996 and the Outlook for Later Years}

In 1996, net borrowing amounted to DKr 11.7 billion, while DKr 16.7 billion was raised by medium- and long-term funding (see

\section{Box 12.1. Central Government Borrowing Norm}

The size of borrowing in any given year is determined by the central government borrouing norm, which is an agreement between the government and Danmarks Nationalbank. The agreement is composed of two parts: a norm for domestic borrowing and a norm for foreign borrowing.

The norm for domestic borrowing states that the issuance of domestic DKr-denominated securities within a year should match the gross borrowing requirement of that year (the gross borrowing requirement being defined as the gross deficit on a cash basis less redemptions on foreign debt).

The norm for foreign borrowing states that redemptions on the foreign debt should be matched by new foreign borrowing.

The norm for domestic borrowing

The norm for domestic borrowing constitutes a firm quota for issuance of domestic DKr-denominated debt and is an important element of the dividing line between fiscal and monetary policy. The norm for domestic borrowing ensures that-for the year taken as a whole--the central government's domestic payments do not affect the domestic liquidity (the banks' net position with Danmarks Nationalbank). At the same time, the norm for domestic borrowing helps the market to predict the volume and timing of the issuance with a certain degree of accuracy.

When timing the domestic issuance within a year, the liquidity position of the banking sector is taken into consideration together with the market situation. The balance of the central government's account with Danmarks Nationalbank is also considered: this balance should be positive at all times. This is a consequence of Article 104 of the Maastricht Treaty, which prohibits monetary financing. 
Table 12.1). Redemptions amounted to DKr 32.1 billion and, together with fluctuations in exchange rates, led to a reduction of the foreign debt of DKr 4.1 billion.

The redemption profile for the foreign debt at the end of 1996 is shown in Figure 12.1. In 1997, total redemptions of the foreign debt amounted to more than DKr 33 billion. The redemptions of the foreign debt will, in accordance with the foreign norm, be financed by new borrowing.

An integral part of the norm for domestic borrowing is that Danmarks Nationalbank in the market buys the foreign currency needed to cover the central government's current expen.ses in foreign currency, including interest payments on the foreign debt. This ensures that the liquidity effects of all central government payments are neutralized. Although the issue of domestic government securities exceeds the domestic deficit, the liquidity effect is neutralized by the buying of foreign currency (in the market) to finance the central government's foreign interest payments.

\section{The normi for foreign borrowing}

The nomn for foreign borrowing implies that redemptions on the foreign debt-including securities bought back from the market and early redemptions-is refinanced by foreign borrowing. ${ }^{1}$

Taken together, the foreign and domestic norms ensure that the central government's total foreign payments do not affect the foreign exchange reserve.

It is possible to deviate from the norm for foreign borrowing. The purpose of the central government's foreign borrowing is to maintain an adequate foreign exchange reserve. Situations may arise where substantial amounts of foreign currency are required for intervention purposes or, conversely, the foreign exchange reserve has risen beyond what is deemed to be necessary. If the foreign exchange reserve rises beyond the desired level, the norm for foreign borrowing can be reduced should the balance on the central government's account with Danmarks $\mathrm{Na}$ tionalbank leave room for such a reduction.

'Bonds bought back from the market of the domestic XEU issue ( $8.5 \%$ 1992/2002) are also covered by the norm for foreign borrowing. 


\section{IB HANSEN}

Table 12.1. Central Government Foreign Borrowing and Debt. Nominal Value

(In billions of annish kroner)

\begin{tabular}{|c|c|c|c|c|c|c|}
\hline & & $\begin{array}{r}\text { Medium. } \\
\text { B }\end{array}$ & $\begin{array}{l}\text { dil Long-Term } \\
\text { owing }\end{array}$ & & & \\
\hline & $\begin{array}{l}\text { Commercial } \\
\text { Paper, Nel }\end{array}$ & Funding & Redempions & $\begin{array}{c}\text { Net } \\
\text { Borrowing }\end{array}$ & $\begin{array}{l}\text { Rate } \\
\text { Adjustment }\end{array}$ & $D_{e b z^{2}}$ \\
\hline 1993 & 5.9 & 68.6 & 16.6 & 57.9 & 2.9 & 164.3 \\
\hline 1994 & -24.9 & 7.5 & 13.7 & -31.0 & -3.5 & 129.8 \\
\hline 1995 & -0.5 & 13.7 & 32.3 & -19.1 & -5.1 & 105.6 \\
\hline 1996,1 & 0.2 & 3.0 & 7.3 & -4.1 & -0.2 & 101.3 \\
\hline 1996,2 & 0.5 & 2.2 & 1.4 & 1.3 & 0.3 & 102.9 \\
\hline 1996,3 & 7.5 & 4.2 & 12.5 & -0.8 & -0.1 & 101.8 \\
\hline 1996,4 & 3.5 & 7.3 & 10.8 & 0.0 & -0.3 & 101.5 \\
\hline 1996 & 11.7 & 16.7 & 32.1 & -3.7 & -0.4 & 101.5 \\
\hline
\end{tabular}

Including buybacks and early repayments.

2Adjusted for buybacks.

Figure 12.1. Denmark's Redemption Profile for Foreign Debt (In billions of Danish kroner)

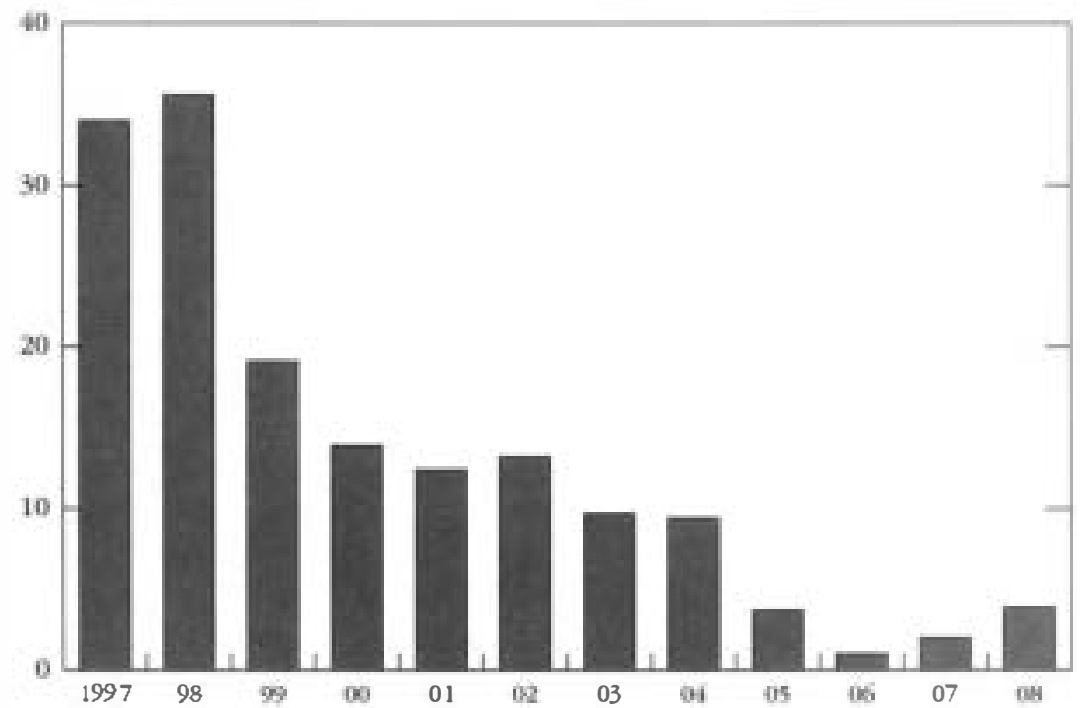

Source: Nalional sources. 


\section{Management of Currency Risk and Interest Rate Risk}

\section{Currency Risk Management}

The foreign debt ${ }^{1}$ of the Kingdom of Denmark and the foreign exchange reserve ${ }^{2}$ are managed within a coordinated framework that provides for an integrated approach to asset-liability management. Management thus focuses on the net foreign debt, which is the foreign debt and the foreign exchange reserve taken as one. Figure 12.2 shows that the net foreign debt has varied somewhat over the years. Owing to an increase in foreign exchange reserves, it fell to the lowest level for many years in 1996.

The net debt is managed via the setting of a benchmark. The benchmark is a poitfolio composed of assets or liabilities in U.S. dollars, ERM currencies, ${ }^{3}$ Japanese yen, sterling, and Swiss francs. The distribution of currencies reflects the trade-off between the expected currency risk and the expected cost of borrowing-the sum of interest payments and gains or losses on foreign exchange fluctuations.

The benchmark is composed of a risk-neutral portfolio and certain strategic deviations from this risk-neutral portfolio. The losses and gains stemming from exchange rate fluctuations versus the Danish krone can be seen as the sum of a general contribution from exchange rate fluctuations versus the risk-neutral portfolio and a specific contribution from the exchange rate fluctuations of the risk-neutral portfolio versus the Danish krone. This distinction makes it possible to separate risks and costs that can be regulated, such as the general exchange rate risk, from those that cannot, such as variations in the Danish krone versus ERM currencies.

The Danish exchange rate policy aims to stabilize the domestic currency against the core ERM currencies. Therefore, the riskneutral portfolio consists of assets and liabilities denominated in ERM currencies. This implies, among other things, that the specific risk attached to variations in the krone versus the ERM currencies is excluded from the considerations leading to the setting of the

'Including ECU-denominated domestic government debt and buybacks.

${ }^{2}$ For this purpose, adjusted for elements such as the stock of gold and SDRs.

3̈In this context, ERM means deutsche marks, French francs, Dutch guilders, Belgian francs, and ECUs. Danmarks Nationalbank sets a benchmark for these currencies itself. 
Figure 12.2. Distribution of the Net Foreign Debt (In btllons of Danisb kgner)

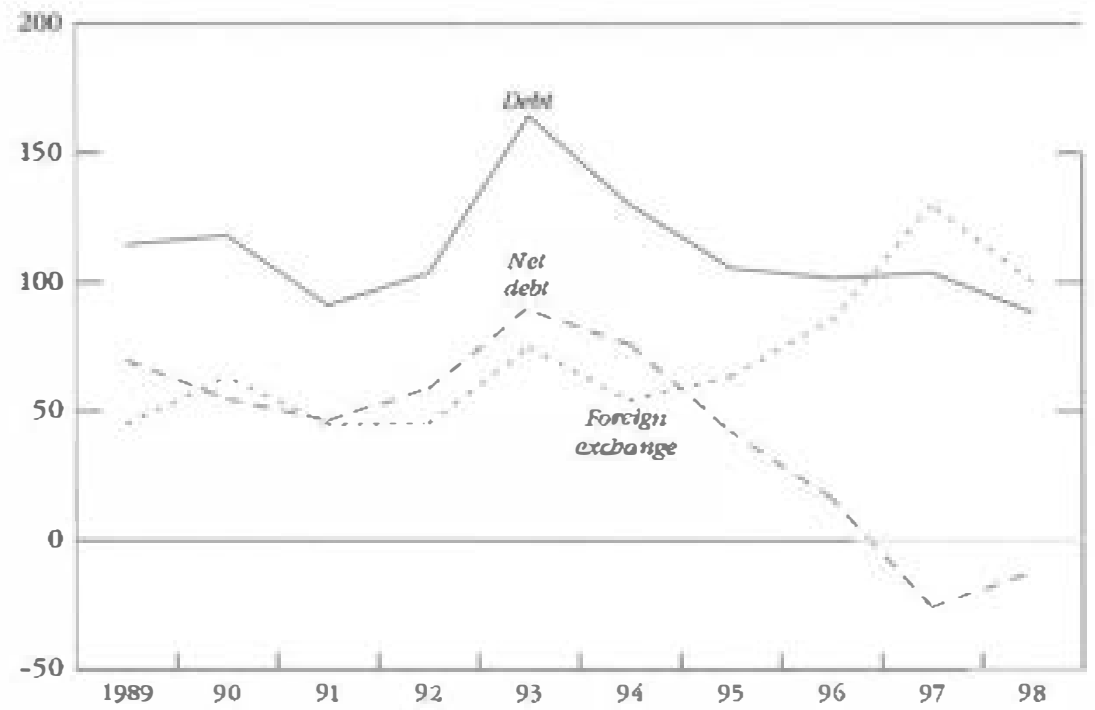

Source: National sources.

Nete: Foreign debt including ECU.denomistated domestic gevernment debt.

benchmark---since the specific krone/ERM risk cannot be affected by the management of the net debt, whereas the general currency risk can.

The net debt is managed with an absolute risk measure. This means that the benchmark is made up as an absolute distribution in billions of Danish kroner, the residual being the core ERM currencies. Changes in the net debt take place in the core ERM currencies. Therefore, the general currency risk does not change when the net debt changes--as the core ERM currencies are considered a riskneutral portfolio.

The benchmark for the net currency distribution is agreed by the Ministry of Finance, the Ministry of Economic Affairs, and Danmarks Nationalbank on a quarterly basis. ${ }^{4}$ Danmarks Nationalbank may take positions against the benchmark within a limit of $\mathrm{DKr} \pm 2.5$ bil-

A standard mean-variance portfolio model is used in the deliberations leading to the setting of the benchmark. 
Table 12.2. Benchmark for the Net Foreign Debt

(In billiens of Danish kroner)

\begin{tabular}{lccccc}
\hline & USS & $y$ & $i$ & $5 W F$ & EHM \\
\hline 1996,1 st qtr. to sth qtr. & -4.0 & 2.5 & 0.0 & 4.5 & Rest \\
1997,1 st qtr. & -2.0 & 2.5 & 1.0 & 2.0 & Rest \\
\hline
\end{tabular}

lion. The benchmarks for 1996 and the beginning of 1997 are shown in Table 12.2.

\section{Interest Rate Risk Management}

Duration is used when measuring the interest rate risk of the foreign debt. At the end of 1996, the duration of the foreign debt was 1.9 years, as shown in Table 12.3 .

There is in general no direct coordination between the assets of Danmarks Nationalbank and the liabilities of the Kingdom of Denmark with regard to interest rate risk. However, as marginal foreign assets and marginal foreign liabilities are required to have a short duration, it is ensured that neither the interest rate risk of the government and the Nationalbank nor the interest rate risk of the two institutions taken together is significantly affected by government borrowing to finance currency intervention or to prevent an overdraft on the government's account with Danmarks Nationalbank.

To illustrate the coordination, consider the effects of a government loan issue. The proceeds in foreign currency are sold to Danmarks Nationalbank, where it adds to the foreign exchange re-

Table 12.3. Foreign Debt Distributed on Currencies and Duration

$\frac{\text { Patt of Total Debt, } 1995 \quad \text { Part of Total Debt, } 1996}{\text { Percent }}$

$\frac{\text { Duration, } 1996}{\text { Years }}$

\begin{tabular}{lrrl} 
DM & 44 & 74 & 1.9 \\
US\$ & 4 & 2 & 1.2 \\
SwF & 12 & 6 & 1.5 \\
F & 9 & 7 & 2.6 \\
L & 9 & 5 & 2.0 \\
¥ & 8 & 2 & 1.2 \\
ECU & 12 & 3 & 1.2 \\
N.G & 1 & 0 & 2.3 \\
Others & 1 & 1 & -1.9 \\
Total & 100 & 100 & \\
\hline
\end{tabular}


Table 12.4. Foreign Borrowing of 100 to Finance Currency Intervention

\begin{tabular}{|c|c|c|c|c|c|c|}
\hline & \multicolumn{2}{|c|}{ Government } & \multicolumn{2}{|c|}{ Nationalbank } & \multicolumn{2}{|c|}{$\mathrm{Net}$} \\
\hline & DKr & $\begin{array}{c}\text { Foreign } \\
\text { exchange }\end{array}$ & DKr & $\begin{array}{l}\text { Foreign } \\
\text { exchange }\end{array}$ & DKr & $\begin{array}{l}\text { Foreign } \\
\text { exchange }\end{array}$ \\
\hline $\begin{array}{l}\text { Official foreign exchange reseive } \\
\text { Government account } \\
\text { Govemment net foreign assets } \\
\text { Net assets }\end{array}$ & 100 & -100 & -100 & 100 & $\begin{array}{l}0 \\
0\end{array}$ & $\begin{array}{r}100 \\
-100 \\
0\end{array}$ \\
\hline
\end{tabular}

serves, and the receipts in Danish kroner are deposited on the government account with Danmarks Nationalbank. Therefore, there is a simultaneous increase of the assets and liabilities of the government and Danmarks Nationalbank, as shown in Table 12.4. The net debt, however, is unchanged - as the counterpart to the additional government foreign debt is the increase in Danmarks Nationalbank's currency reserves.

The yield on the deposit on the government account with Danmarks Nationalbank is the discount rate-a variable rate. Danmarks Nationalbank's discount rate is more closely correlated to foreign short-term rates than to foreign long-term rates. Therefore, to minimize the government's increase in interest rate risk, the rate on the marginal loan should be variable too. 5

An analogous argument applies to Danmarks Nationalbank. The yield paid on the additional liability is the discount rate. As a consequence, to limit the increase in Danmarks Nationalbank's interest rate risk, the additional currency is placed in short instruments.

The net foreign debt is unchanged. The increase in government debt corresponds to the increase in foreign exchange reserves. As the interest rate is variable in both cases, the change in the interest rate risk on a net basis is limited to the least possible.

Suppose now that Danmarks Nationalbank spends part of the additional reserves for intervention to support the krone. By this transaction, Danmarks Nationalbank is replacing assets in foreign currency with assets in krone by improving the Nationalbank's net domestic currency position against the financial institutions as in Table 12.5.

\footnotetext{
5The risk is, however, not eliminated totally because the correlation between foreign variable rate and the discount rate is less than 1.
} 
Table 12.5. Foreign Borrowing of 100 to Finance Currency Intervention of 60

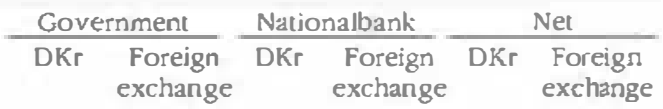

Net position vis-à-vis the financial institutions

Official foreign exchange reseive

Government account

Government net foreign assets

Net assets

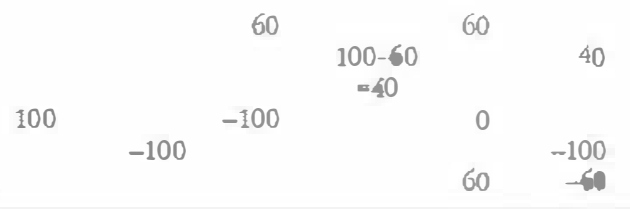

As it appears from Table 12.5, the net foreign debt increases in this case. The counterpart is the improvement of Danmarks Nationalbank's krone position against the financial institutions. The yield on financial institutions' borrowing or depositing with Danmarks Nationalbank is closely related to the Danish discount rate. Consequently, the effect on interest rate risk on a net basis is minimizedas long as the additional government debt and the associated increase in official reserves pay a variable yield.

To sum up, by ensuring that the marginal foreign assets and liabilities have a short duration, it is secured that neither the interest rate risk of the govemment and Danmarks Nationalbank, respectively, nor the interest rate risk of the two institutions taken together is affected significantly by government borrowing to finance currency market intervention or to prevent an overdraft on the government's account. 


\title{
13 \\ Credit Costs and Borrowing Capacity in Debt Optimization
}

\author{
Alejandro M. Pilato
}

\section{Impact of Credit on Borrowing Decisions}

Tn recent years, volatility in the Japanese yen exchange rate has focused attention on the risk implicit in the level of yen borrowing for many sovereign borrowers. There may be cost advantages to borrowing in yen, as well as the simple fact of availability of funds from Japanese investors. However, these advantages have to be offset against the potential for high volatility in the market value of the debt. The swap market has provided a mechanism for eliminating market risk, but the use of swaps also poses a host of other issuessuch as the possibility of counterparty default and heavy usage of credit lines.

The advance in secondary credit transactions, such as the interbank use of credit derivatives, is imposing a more homogeneous view of relative credit quality and marginal return on credit exposure, in the same way that development on the interbank swaps market imposed the LIBOR curve as a standard reference. But, for low-credit borrowers, the analysis of credit on funding decisions is complicated by the consideration of credit line utilization, and its interaction with direct credit extended through loans or bonds. In this paper, we present a debt optimization framework that takes into account borrowing capacity risk in addition to the conventional measures: cost and volatility of cost.

For high-credit borrowers, the pursuit of arbitrage opportunities has meant that the currency of debt issuance has become indepen- 
dent of the ultimate currency of exposure. However, with the contraction of the size of arbitrage available, it becomes more important for issuers to be sure that all apparent cost gains are not at the expense of expected future credit losses. In this paper, we describe an approach to measure the "cost" of swap counterparty credit risk based on the combination of the expected exposure and the counterparty's funding spreads.

\section{Debt Optimization for Lower-Credit Sovereign Borrowers}

Borrowers who are constrained by the availability of funding sources in the domestic market may often be forced to borrow overseas. To avoid taking currency risk, this debt must be swapped back to the domestic currency. However, sovereign borrowers are unlikely to embark on such a swaps program for fear of sending unwanted signals to the market. In any case, such a strategy could not be implemented without a liquid domestic swap market, which in turn could not exist without a well-developed domestic debt market. Altematively, sovereign borrowers could swap foreign currency debt back to either the currency components of the currency basket used for the management of their domestic currency or to a minimum volatility currency composition, to leave just devaluation risk. This introduces three of the factors that enter the decision process. The first two factors are the conventional market risk and return, while the third factor is the availability of credit lines or borrowing capacity' risk.

There is an increasing overlap between the swaps market and investment community. Syndicated loan and bond markets are gradually converging toward a single market. Hence, if credit lines are a constraint for a borrower, credit usage through swap transactions competes with direct credit extended by investors through loans or bonds. It is therefore important for lower-credit borrowers to understand how counterparties determine their internal credit line limits in order to quantify their borrowing capacity.

\section{Setting and Utilizing Credit Lines}

Credit linits are generally set with reference to the maximum exposure on swaps. If exposures can be netted among transactions with a single legal counterparty, the maximum exposure can be cal- 
culated for the swap portfolio as a whole, taking into account internally offsetting risks. Theoretically, allocation of credit usage and pricing decisions should then be made based on expected (or most likely) default cost, which is linked to the expected exposure as a function of time. Few counterparties, however, will base limits and their utilization on different measures. Many will use the concept of either peak exposure or average maximum exposure as a guide for both setting and utilizing credit limits (see Figure 13.1).

The maximum exposure at a given time in the life of a swap is defined as the worst exposure that will occur with 5 percent probability. The peak exposure is then defined as the greatest maximum exposure at any time in the life of a swap. While the maximum exposure depends on how a swap responds to a particular market scenario that has a 5 percent probability of occurrence, the expected exposure captures the average overall market scenarios where the swap net present value is positive. Expected exposure takes into ac-

Figure 13.1. Maximum and Expected Exposure Through Time (US. dollars/Japanese jen)

(Exposure in millions of U.S. dollars)

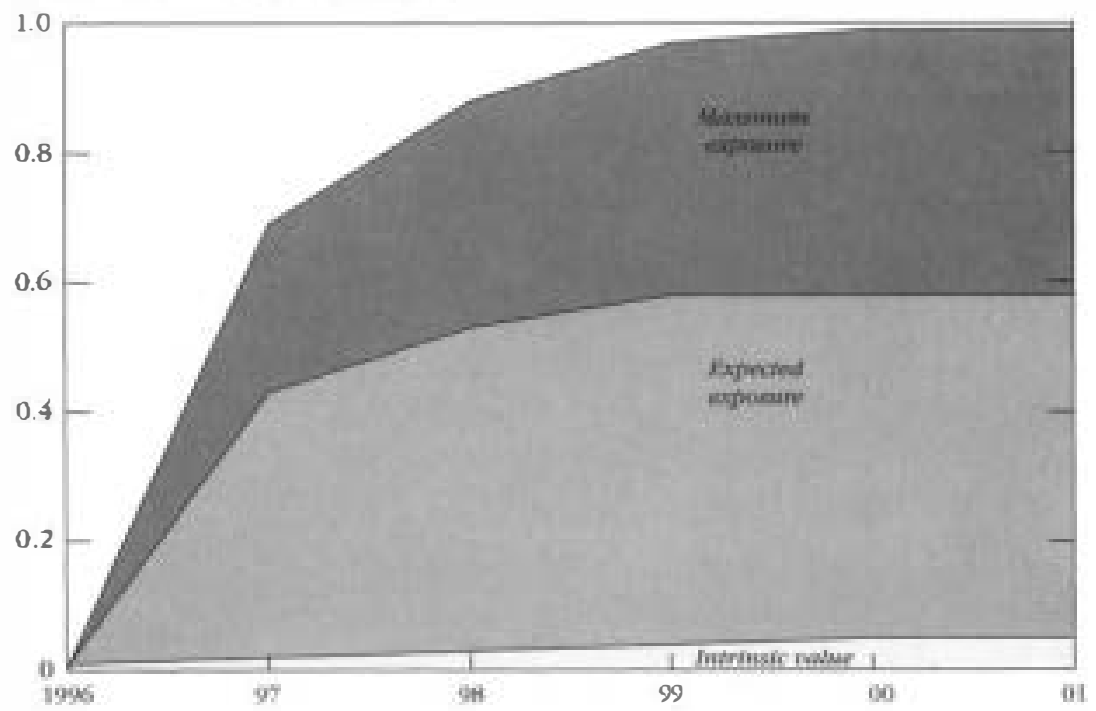

Source: Author's calculations. 
count diversification of market exposures within a swap portfolio and diversification of market movements.

Expected exposure information is combined with assumptions specific to the counterparty on probability of default and recovery rate, both as a function of tine, to provide the expectation of default cost on a swap portfolio.

Historic data on probability of default and recovery rate is difficult to obtain and to manipulate because the underlying events are "lumpy." Market-implied default probabilities, however, can be derived from funding spreads over LIBOR for counterparties of a particular credit rating. These funding spreads can be combined directly with the expected exposure to give the expected default cost on the portfolio (see Figure 13.2).

Note that a credit limit based on peak exposure, or even based on the average of maximum exposure, will generally disfavor swaps since, for example, a domestic currency loan will be at its maximum exposure in all market scenarios throughout its life, while a swap will by definition be at its maximum in just 5 percent of scenarios. Even though the maximum-exposure-based calculation may not be the ideal way of allocating credit lines across business (e.g., lending against swaps), it is the one generally applied in practice, and so is the one that should be analyzed by lower-credit borrowers.

It should be noted that the use of collateral or swap mark-tomarket mechanisms reduce counterparty exposure at the expense of cash-flow uncertainty. The logistical problems caused by cash-flow uncertainty alone will always restrict the use of credit mitigation mechanisms by sovereign borrowers irrespective of how widespread their use becomes among supranationals and other financial institutions. Moreover, the reduction of exposure through credit mitigation mechanisms is frequently overestimated. For example, a swap with six-month full mark-to-market provisions is sometimes incorrectly regarded as analogous to six-month risk. Although the intrinsic component of the exposure resets to zero at each mark-tomarket date, the time value does not.

\section{Trade-Off Between Cost, Volatility of Cost, and Borrowing Capacity}

The use of swaps by lower-credit sovereign borrowers can result in credit lines getting used up. This would in turn mean that future 
Figure 13.2. Default Probabilities (Using Funding Spreads as Proxies) Versus Credit Rating and Maturity

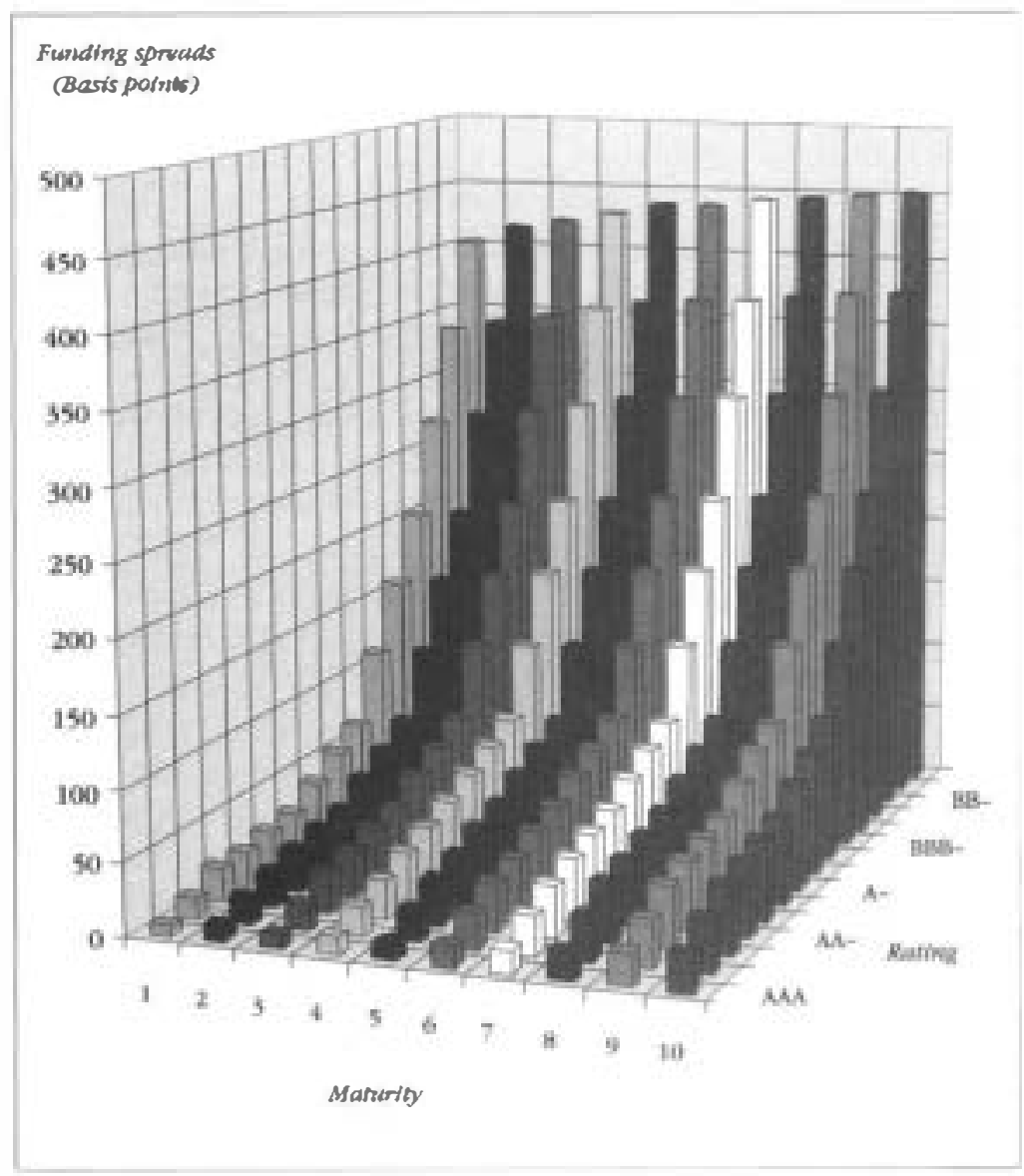

Source: Author's calculations.

overseas funding could not be swapped into a minimum risk currency composition and would be subject to currency risk. Alternatively, the borrower would be forced to deal with lower-credit swap counterparties, which could increase the borrower's expected cost through counterparty default. 
Therefore, there may be an incentive to borrow in low volatility currencies-so as to minimize the time value component of the swap's exposure, and hence credit line usage, even if these currencies do not offer the lowest gross funding cost. Alternatively, it may be attractive to borrow in whatever currency in which there is investor demand-without hedging back into domestic currency, and accepting the resulting currency risk. If credit lines are not a constraint, the borrower will be able to hedge market risk completely through swaps, but will take a small credit exposure to counterparties in doing so. The impact this has on funding decisions is examined below.

When credit is a constraint, the necessity to raise a certain amount of overseas funding will limit the borrower's ability to hedge completely. In this case, the borrower can aim to minimize the volatility of costs and maximize borrowing capacity while taking advantage of the lowest available debt cost. This can be analyzed through a three-dimensional efficiency frontier, which represents the optimum funding decision expressed as a choice among the three variables (see Figure 13.3).

In this example, the third axis measures borrowing capacity, a quantity that dominates the decision-making process in many circumstances. Borrowing capacity is also defined on a time-weighted basis to take into account the importance of locking in funding for longer maturities. This requires knowledge of the distribution of the maximum exposure on a swap portfolio through time. For example, to minimize cost, a borrower could raise funds in yen, which creates a high exposure to market risk. This risk can in turn be eliminated by using swaps, but only at the expense of utilizing credit lines and hence reducing remaining borrowing capacity.

If borrowing capacity is to be maximized, market risk must be taken, and the result is the traditional two-dimensional frontier describing the trade-off between expectation of cost and volatility of cost. A point of minimum risk exists at the "minimum risk foreign currency composition." If the borrower is prepared to exchange some borrowing capacity for flexibility in reducing volatility and expected cost, the solution on the efficiency frontier involves swapping a proportion of the foreign borrowings. The optimum composition of the swap portfolio can be understood as approximately that which will preserve the unswapped part of the portfolio at the "minimum risk foreign currency com- 
Figure 13.3. Three Factors in Funding Decisions

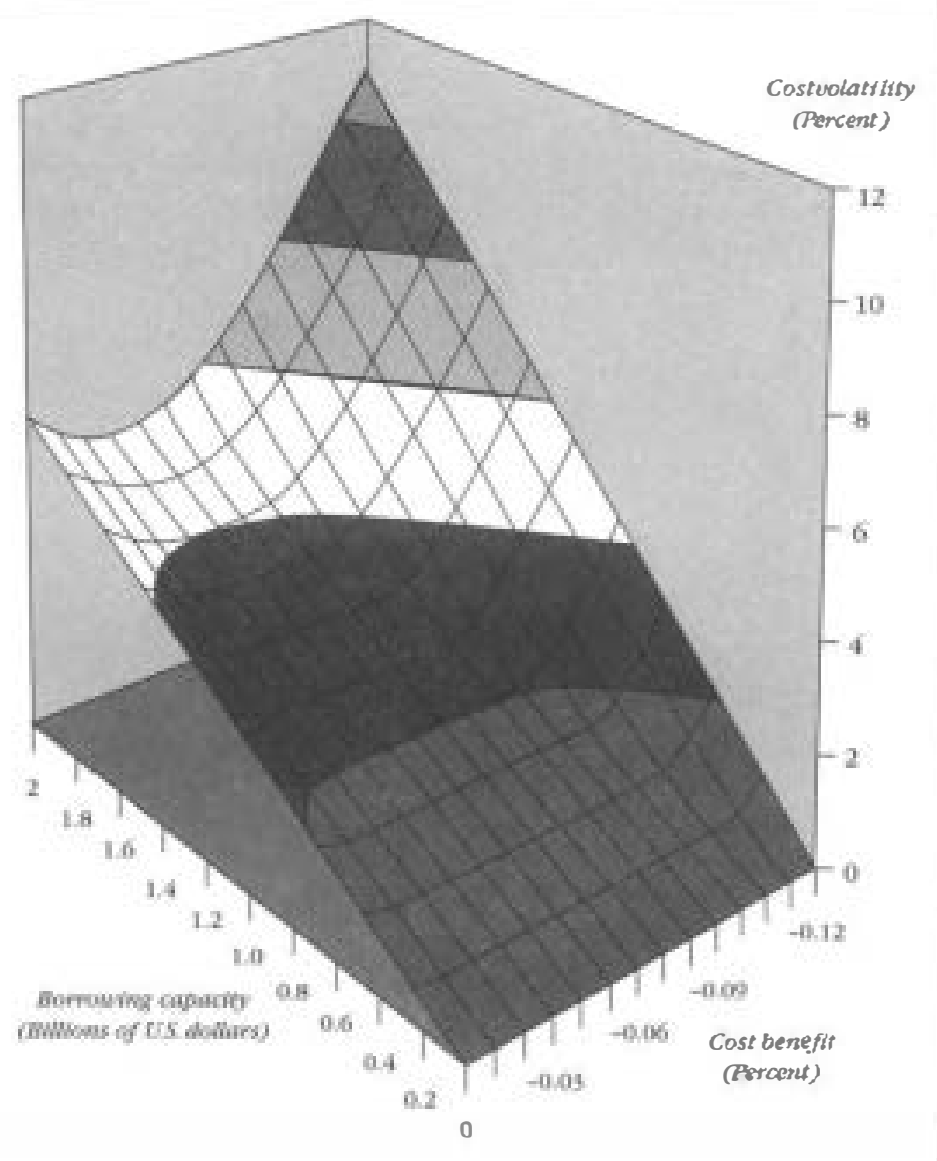

Source: Authos's calculations.

position." This means that for each of a range of underlying debt issuance compositions, different swap strategies will enable the resulting net exposure to be identical to domestic borrowing plus foreign borrowing allocated in the "minimum risk foreign cur-

In reality, the optimization process takes into account the counterparty credit cost assumed by the borrower by entering into the swaps. This pulls the optimal solution away from the shape that would be implied by the above simplified explanation. 
rency composition." This phenomenon gives rise to a flat triangular surface in the efficiency frontier, where each horizontal line across the surface represents the continuum of borrowing strategies, all of which can be swapped to the "minimum risk foreign currency composition." However, outside these ranges, for a given level of borrowing capacity, there is not sufficient flexibility to swap the remaining net foreign exposure into the right composition, so more cost volatility must be assumed to take advantage of the available cost benefits. Hence, we see curved efficiency surfaces attached to the edges of the triangular plane.

The funding decision precess can be formalized by describing a utility between any pair of risk and cost measures. For example, the borrowing cost benefit can be measured against borrowing capacity risk by comparing this with the cost that a borrower is prepared to pay for the existence of an undrawn credit facility. We could assume credit limits are not an absolute constraint but that the cost of incremental exposures rises quickly as they are approached. Similarly, expected cost and volatility of cost can be combined using the Sharpe ratio.

\section{Funding Decisions for High-Credit Sovereign Borrowers}

Lower funding costs may be available through foreign borrowing for reasons such as name scarcity. Alternatively, sovereigns may opt to raise funds overseas for more strategic reasons, such as diversifying the investor base or to raise foreign currency reserves directly. Overseas borrowing can be swapped into domestic currency to avoid currency risk, but borrowers must account for the expected cost of default by their swap counterparties. This will offset some of the gain in funding cost.

If all foreign borrowing is concentrated in one currency, the scenario of strength in this currency will cause high-credit exposure on all swaps simultaneously. The expected credit exposure to the banking community as a whole of the swap portfolio is therefore lowered if the portfolio of foreign borrowings is diversified across different currencies. This means there is an optimal amount of diversification that will minimize net effective funding costs, taking into account both the gross funding cost and credit costs. For example, it may be worth paying higher gross funding cost in some

\section{(C)International Monetary Fund. Not for Redistribution}


currencies for the net effective funding cost gain that is brought about by exposure diversification.

\section{An Example}

A U.S. dollar-based borrower can raise funds at LIBOR minus 12.5 basis points in Japanese yen or at LIBOR flat in Australian dollars after accounting for the effect of long-dated basis costs. Assume that the borrower charges credit on an economic basis with counterparties AA or better. The following are the net costs of different borrowing profiles:

100\% Japanese yen:

LIBOR $+1.2 \mathrm{bp}$

100\% Australian doliars swapped into yen:

LIBOR +1.4 bp

Optimal ratio:

$38 \%$ Japanese yen, $62 \%$ Australian dollars

swapped into yen

LIBOR $-1.1 \mathrm{bp}$

While gross cost considerations clearly favor Japanese yen borrowing, the economic credit cost of a long-dated yen cross-currency swap with final exchange is substantial. This is caused both by the high Japanese yen currency volatility and by the interest rate differential between Japanese yen and U.S. dollars, which means that the borrower expects to be in the money at the maturity of the swap. Conversely, the relatively low Australian dollar currency volatility and the positive interest rate spread both reduce the economic credit cost and offset the gross cost disadvantage.

\section{Interest Rate Differential Versus Foreign Exchange Volatility}

Figure 13.4 illustrates that, for long-dated currency swaps, interest rate differentials have as much importance as foreign exchange volatility in determining credit exposures. The former determine the intrinsic component of the exposure, while the latter determine the time value component. For example, even if yen were a low volatility currency seen from a U.S. dollar base, a long-dated swap to receive yen would entail higher credit exposure than a swap in a high volatility currency without the same interest rate differential. 
Figure 13.4. Profile of Credit Exposure

Impact of Interest Rate Differential and Foreign Exchange Volatility (In millions of US. dollars)

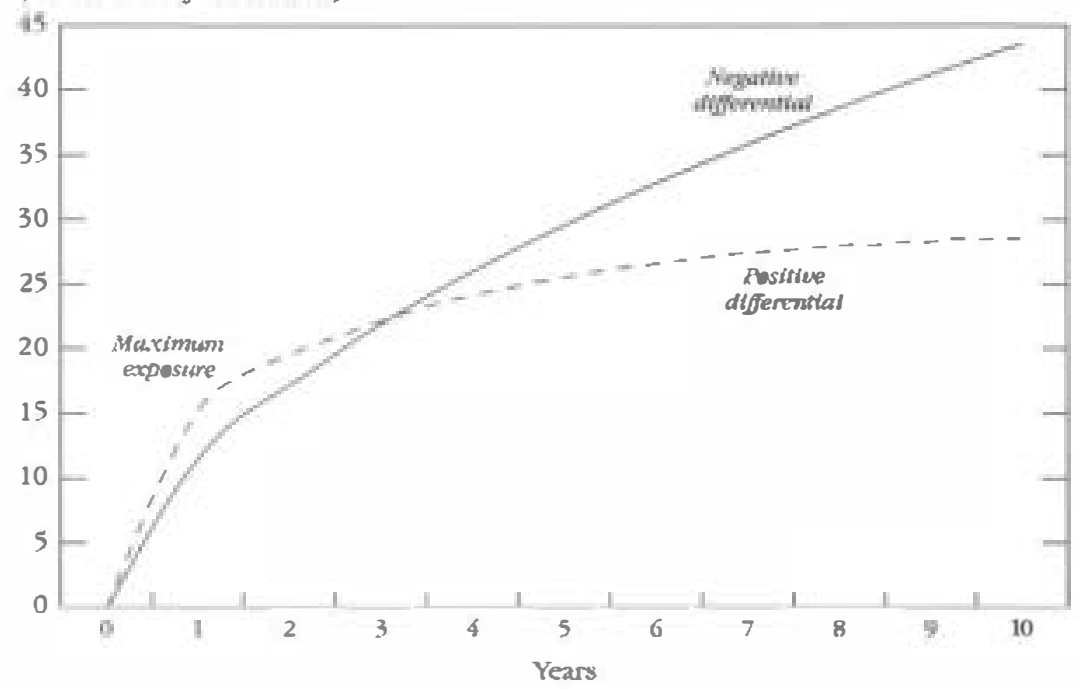

Sourcc: Author's calculations.

Figure 13.5. Optimizing for Cost of Credit (n percent)

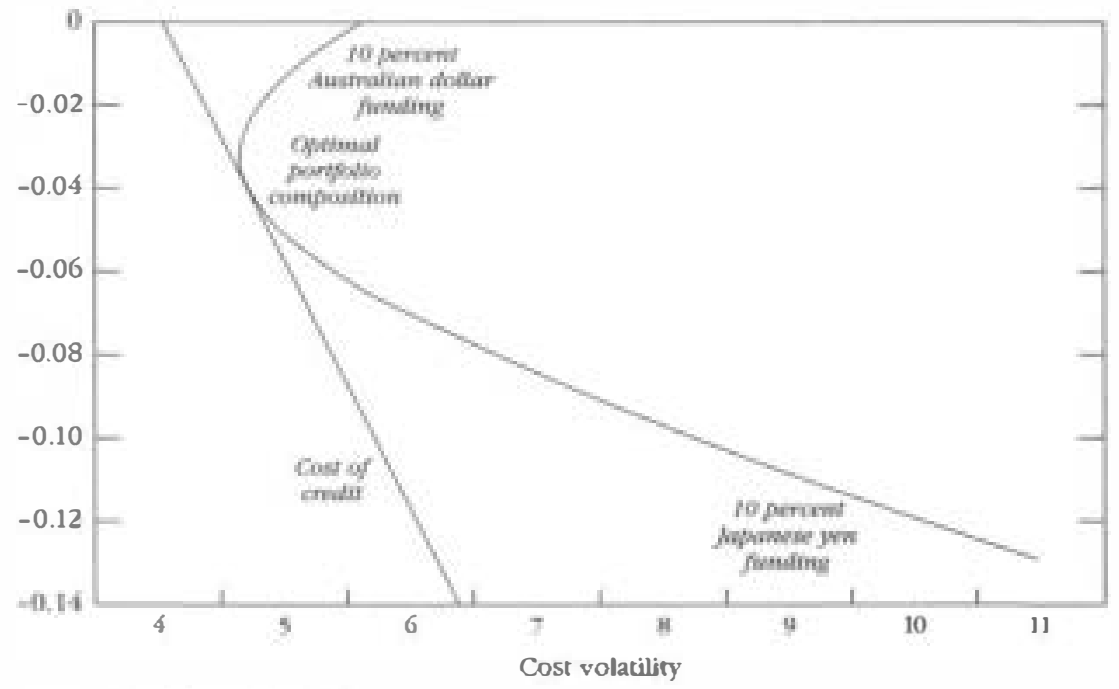

Source: Author's caliculations. 
Further, the lack of correlation between the Australian dollar and the yen implies that a certain amount of diversification out of Australian dollars will actually reduce portfolio volatility. This means that it is possible to raise a proportion of funding in Japanese yen and take advantage of its cost benefits without eliminating the benefit by increased economic credit cost. This optimal point is about one-third Japanese yen and two-thirds Australian dollars, as illustrated in Figure 13.5. 


\title{
14
}

\section{Risk Management Process for Central Banks}

\author{
Thomas E. Klaffky, Francis D. Glenister, \\ and Judith B. Otterinan
}

The topic of risk management has recently gained prominence in 1 the world of fixed income investing. Software vendors are of fering "complete" systems; bond dealers are offering data and publishing research; and investment advisers and consultants are offering their expertise at controlling risk. It appears that anyone who ignores risk management does so at his or her own peril. However, it is quite likely that today's risks are no more difficult to manage than yesterday's risks and that the introduction of new tools has led to a renewed focus on an age-old problem. In this paper, we will focus on the topic of risk management: the meaning and the uses. In particular, we will focus on how central banks might employ some new approaches to improve their understanding and their management of risk. We will offer a five-step process that may help form a foundation for effective risk management.

\section{Risk Management - Why Bother?}

The first question that arises in the discussion of risk management is: Why bother? What is it about risk that makes us wish to understand it better? The answer depends on the nature of the institution, but probably falls into one of the following categories:

- to control the magnitude of potential losses;

- to allocate capital among various business segments and charge appropriately; 
- to measure risk-adjusted performance; and

- to report to regulatory authorities and rating agencies.

Since it is difficult to manage things that cannot be defined and measured, an objective, consistent definition of risk can help an organization form a common frame of reference and create a risk management process that fits its objectives.

\section{What Is Risk?}

Traditionally, risk management has been a backward-looking process that, as much as anything else, was focused on identifying the culprit for activities gone wrong. In other words, if something went wrong then, by definition, you took too much risk. The primary advance in the current thinking about risk is that risk management should be forward-looking rather than backward-looking. Risk should be something that is anticipated rather than something that is feared. Indeed, since it is necessary to accept some possibility of loss in the pursuit of almost any investment return, one could define risk as the exposure to the possibility of loss. Regardless of the objectives of the assets under management, it is critical for fund sponsors to define the boundaries for acceptable risk and create a process that ensures that these boundaries are not violated.

In May 1994, the United States General Accounting Office (GAO) identified a number of general types of risk that apply to many financial activities. ${ }^{1}$ These risks can be summarized as follows:

Market risk: adverse movements in the price of a financial asset.

Credit risk: failure of a counterparty to meet all financial obligations.

Liquidity risk: availability of a reasonable market for the securities held in a portfolio.

Legal risk: $\quad$ action by a court or regulatory body to invalidate a financial contract.

Operations risk: deficient procedures, human error, system failure, or fraud.

This list of risks may not be comprehensive, but it immediately demonstrates that to create a comprehensive risk management

1U.S. General Accounting Office, "Financial Derivatives: Actions Needed to Protect the Financial System," May 1994. 
process, a central bank must create more than a quantitative approach to measuring and managing market risk.

\section{Creating a Risk Management Process}

To adequately control risk, it is necessary to create a multistage process that focuses on the specific risks that the portfolio faces. There is no "one size fits all" risk management process. Indeed, it may be argued that, for central banks that frequently hold shortduration assets, liquidity risk and operations risk may each pose a greater exposure to loss than market risk. On the other hand, for other financial institutions, especially those that depend on borrowed funds, invest in long-duration assets, or hold securities in a wide variety of asset classes, market, credit, and legal risk may take on far more prominence.

A possible multistage risk management process would involve:

- risk measurement:

-price distributions,

- measuring portfolio risk,

- value-at-risk (VAR), and

- using VAR with an investment benchmark;

- risk management systems;

- rules of behavior;

- mechanism to check compliance; and

- perfomance attribution.

\section{Price Distributions}

When many portfolio managers begin a discussion of risk, they think first about possible adverse changes in the price of their assets owing to changes in the market. From a quantitative point of view, the most commonly used tool to manage the market risk of fixed income securities is duration. Duration is a measure of the percentage price sensitivity of a security (or portfolio) to a small change in interest rates, and, hence, knowing duration and market value allows the calculation of the change in value for a given change in interest rates. Unfortunately, in a risk management context, while duration tells how much asset values will change as interest rates change, it does not provide information about the likelihood or 
Figure 14.1. Monthly Yields of Five-Year U.S. Treasury Bonds Over the Past Tiwenty Years

(In percent)

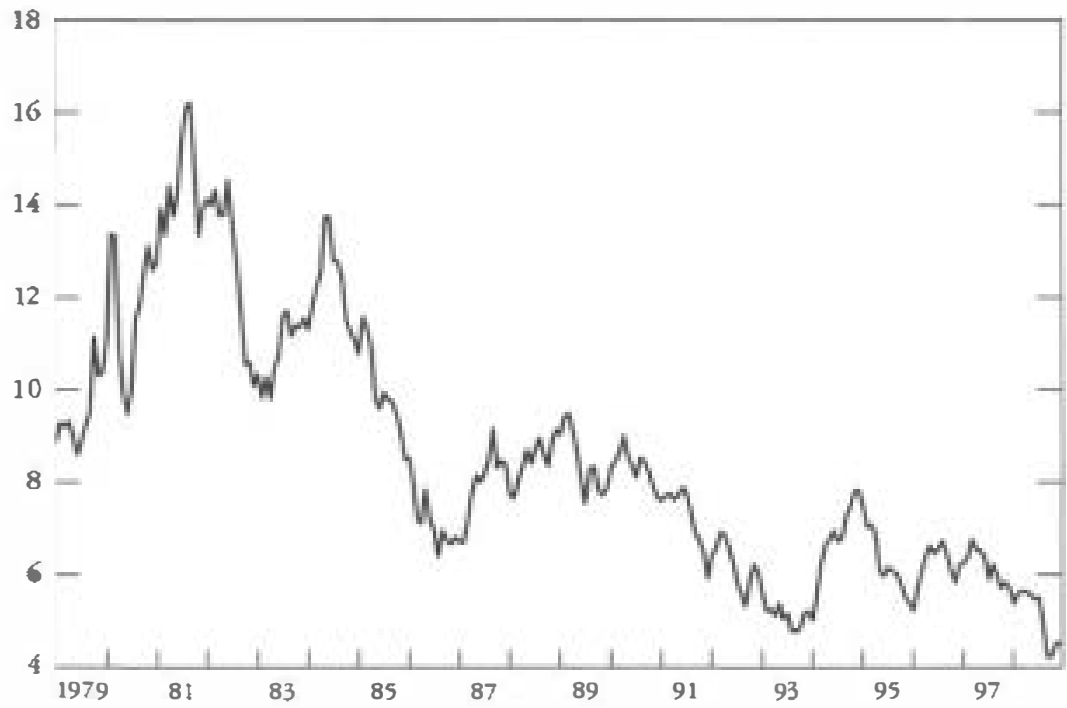

Source: IMF, Interniational Financial Statistics.

magnitude of an interest rate change. Therefore, duration does not directly equal price risk. To get a useful measure of price risk, it is necessary to have both duration and expected yield change. ${ }^{2}$

Figure 14.1 shows the monthly yields of five-year U.S. Treasury bonds over the past 20 years. It is clear that over this time, the market experienced a wide range of interest rate levels. But can we learn anything from the magnitude of past interest rate changes? If we examine all of the monthly changes independently (Figure 14.2), we can see that the majority of these monthly changes fell within plus or minus 50 basis points, which seems to indicate more market stability than is evident from Figure 14.1. Will the future changes in five-year Treasury yields follow this same distribution? The answer to this question is part of the art (rather than science) of risk management, and should be answered in the context of an overall

2Actually, in a risk management context, the most important objective is understanding the distribution of returns rather than prices. 
Figure 14.2. Distribution of Five-Year Treasury Monthly Yield Changes Over the Past Twenty Years

(In bessis points)

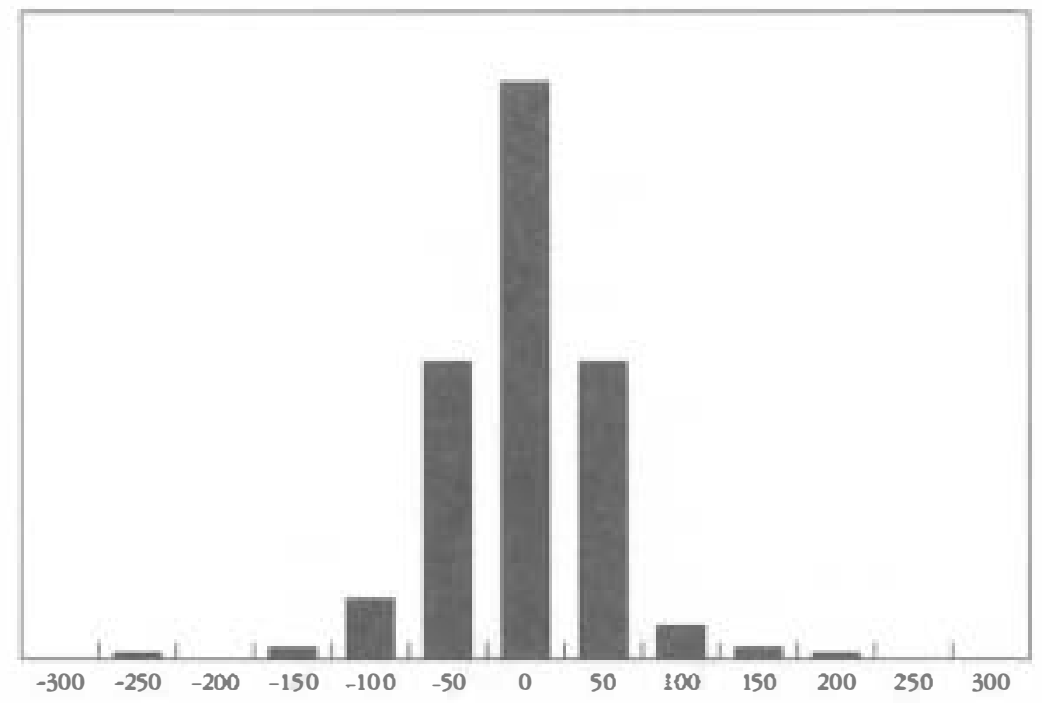

Source: Author's calcularions.

risk management process. However, for the sake of our example, let us assume that we expect the fiture to approximate the past.

Figure 14.3 shows the continuous distribution of percentage price changes for a five-year and a two-year Treasury bond based on the historical yield distribution for each. ${ }^{3}$ From Figure 14.3, it is evident that the distribution for the two-year bond is more tightly bounded than that of the five-year bond. This relationship should not be surprising since the duration of the two-year bond is smaller than that of the five-year, and therefore, its expected percentage price change distribution will always be tighter unless its expected yield volatility is much greater.

Figure 14.4 shows the same bonds as those shown in Figure 14.3, but now a probability of loss of 2 percent (over a one-month holding period) has been introduced for each bond (indicated by the shaded region). It is interesting to note the different probabilities of

${ }^{3}$ A normal distribution has been constructed with the same standard deviation and mean as the distribution of discrete percentage price changes.

\section{CInternational Monetary Fund. Not for Redistribution}


Figure 14.3. Distribution of Two-Year and Five-Year Treasury Monthly Price Changes Over the Past Twenty Years

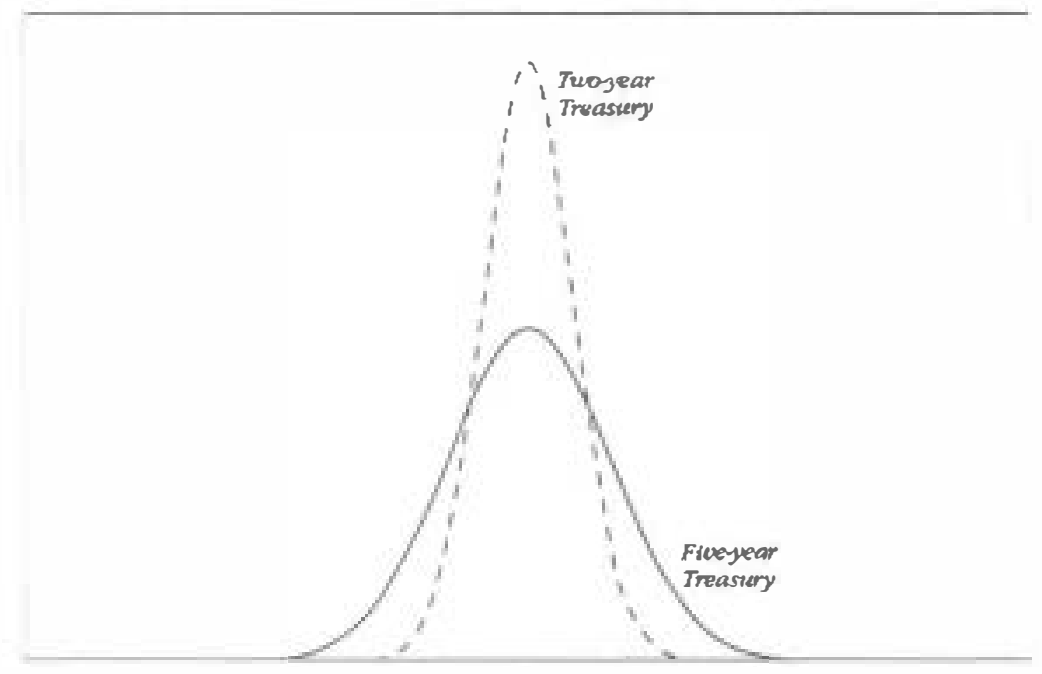

Percentage price change

Seurce: Auther's calculations.

loss for each of these two bonds. For a 2 percent price loss over any given month, the five-year bond has a probability of 15 percent, while the two-year bond has a probability of 3 percent. Once again, the smaller duration leads to less-expected price risk. In many cases, when portfolio managers control duration, they are really controlling these percentage price distributions intuitively. Portfolio managers who work in the markets every day reduce duration to reduce the possibility of loss, even though duration equates to price risk only when yield volatility is present.

\section{Measuring Portfolio Risk}

Let us now turn away from the examination of these securities to look at portfolio market risk. If a portfolio contains both of these securities, will the portfolio's expected price change distribution be the statistical average of the two securities independently? The answer is maybe. If the prices of these securities can be expected to 
Figure 14.4. Probability of a 2 Percent Price Loss-Two-Year and Five-Year Treasury Bonds

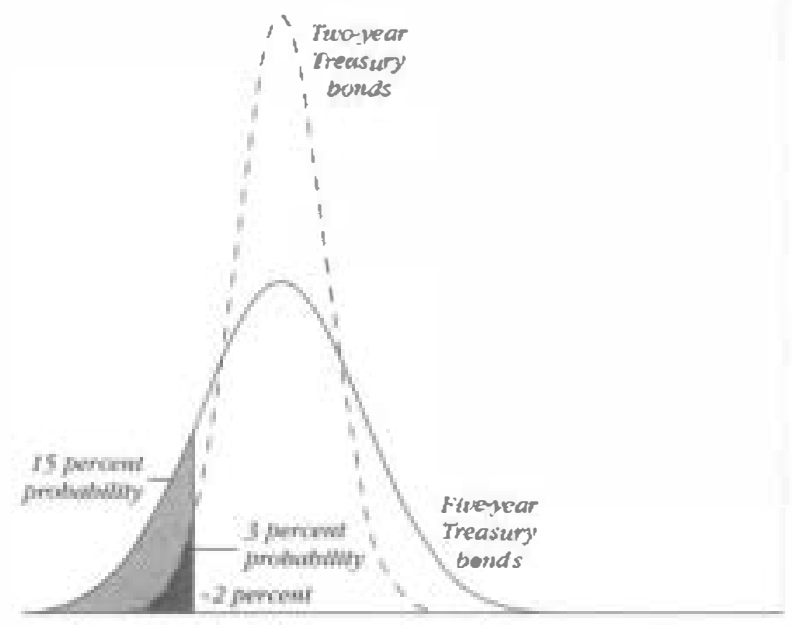

Percentage price change

Soutc: Author's calculations.

move in lockstep (correlation $=1.00$ ), the portfolio distribution will be the weighted average of the individual security distributions. However, if the securities are not perfectly correlated, the portfolio will experience diversification benefits and the ponfolio risk will be less than the weighted sum of the risks of the independent pieces.

To understand the effect of diversification, consider the expected price distributions of two assets (Figure 14.5). In Figure 14.5, the assets are perfectly correlated, so that when the price of one moves, the price of the other can be expected to move in the same direction by the same proportion. Therefore, Portfolio AB can be calculated accurately as the weighted average of the distributions. Now let us say that if the price changes of these securities are not perfectly correlated (correlation $=0.50$ ), we should no longer expect one to shadow the other, even though their past distributions are a good indication of the distribution of future price changes for each one independently. In this case (Figure 14.6), the distribution for the portfolio will be more tightly bounded than that of the weighted av- 
Figure 14.5. Price Risk of a Portfolio With Perfectly Correlated Price Changes

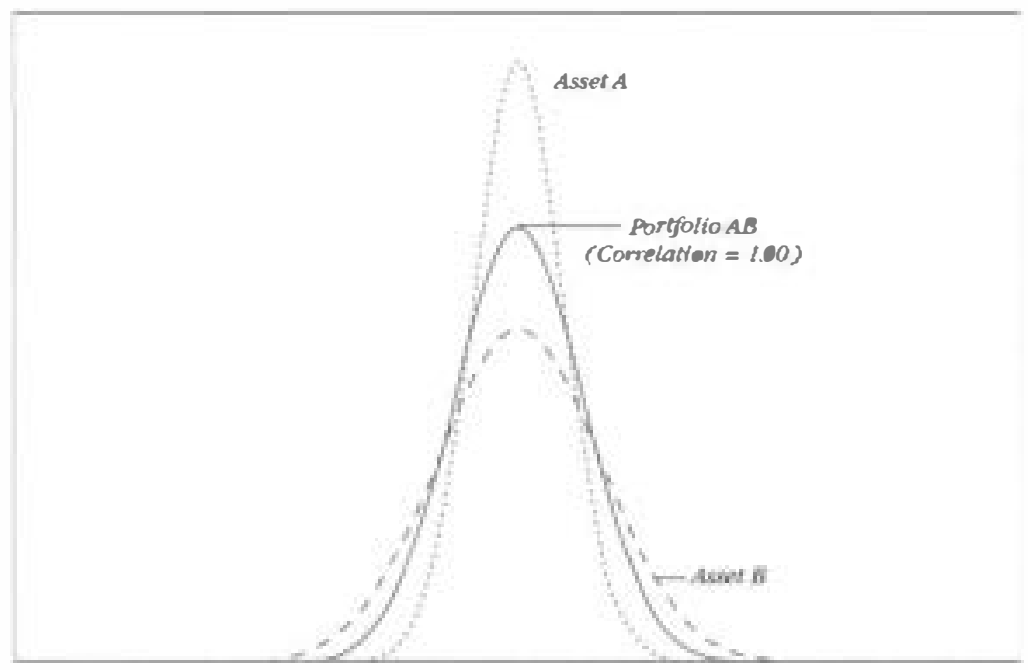

Percentage price change

Source: Author's calculations.

erage introduced above. Intuitively, with perfect correlation, we should expect each security to experience gains and losses at the same time. On the other hand, with less than perfectly correlated price changes, gains in one security will occasionally offset losses in the other and, as a result, the price volatility of the portfolio will be lower than that of the weighted average of the assels. Therefore, the portfolio duration will provide a good measure of portfolio price sensitivity only when the assets in the portfolio are highly correlated. In most single-currenky portfolios, interest rate changes along the yield curve are highly correlated and, hence, duration works well as a measure of portfolio risk, especially when it is combined with some measure of yield volatility. ${ }^{4}$ In a multicurrency portfolio, the average portfolio duration will not have much meaning.

${ }^{3}$ The calculation of portfolio duration implicitly assumes that all interest rates move in unison. In situations where interest rates along the yield curve are highly correlated, this condition is more easily satisfied. 
Figure 14.6. Price Risk of a Portfolio With Not Perfectly Correlated Price Changes

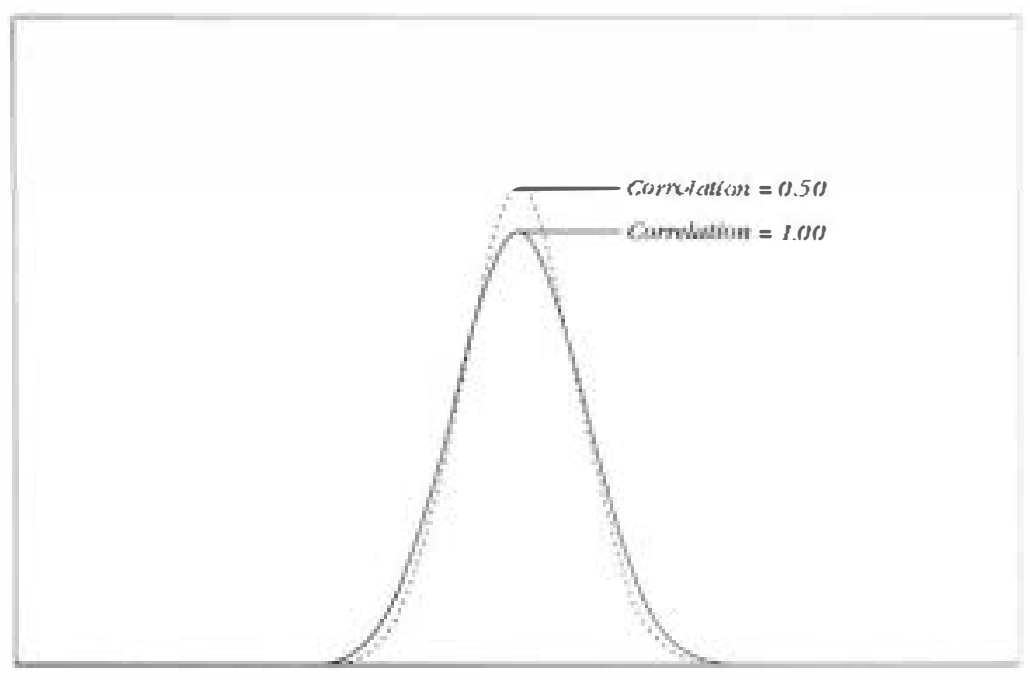

Percentage price change

\section{Value-at-Risk}

It has become popular to measure the market risk of a portfolio using the parameter known as "value-at-risk" (V'AR), which altempts to answer the question: "What is my maximum expected loss for a given probability?" VAR has five key characteristics:

- It provides the maximum expected loss (that is, it focuses on the potential for loss, which is a good intuitive measure of risk).

- It is stated in absolute (rather than percentage) terms.

- It employs a confidence interval (indicating a point on the distribution of returns).

- It is measured over a defined holding period.

- The parameters are chosen by the clecision maker.

To help clarify the meaning of VAR, consider a pertfolio manager who asks: "What is my maximum expected loss with a one-clay holding period and a 95 percent confidence level?" Assuming that 
the answer to this question is $\$ 1$ million, for 19 days out of 20 $(19 / 20=95$ percent confidence), the portfolio loss can be expected to be $\$ 1$ million or less. That is, the daily change in value should be more favorable than a $\$ 1$ million loss, and this will also include daily gains. Equivalently, for one day out of 20, the portfolio loss can be expected to be $\$ 1$ million or greater (a loss that matches or exceeds the VAR). Many financial institutions that currently use VAR measure daily returns and use a 95 percent confidence level because 20 days approximates the number of business days in a month, and hence. the VAR is expected to be exceeded one day during the month.

Alternatively, value-at-risk might be calculated with a 99 percent confidence level, where the VAR might be $\$ 1.4$ million. In this case, the portfolio loss can be expected to match or exceed the VAR for one day out of 100. Calculating the VAR with different confidence levels does not change the distribution of possible outcomes nor does it change the portfolio risk. It only changes the way that the risk is stated by focusing on a different point of the distribution. In a certain sense, measuring more extreme events tends to produce more fear and, thus, tends to lead to risk-avoidance behavior.

It is important to note that VAR provides the maximum expected loss at a chosen confidence level, but it says nothing about the magnitude of losses beyond that confidence level. In other words, for the small number of observations that the loss is our VAR or worse, we do not really know how much worse the actual outcome might be. To get more information about the points of the distribution beyond the VAR, it is necessary to perform a portfolio stress test that focuses only on the tails of the distribution. It is important to focus on the tails of the return distribution because, in real-world financial markets, these distributions tend to have so-called "fat tails."

In the final analysis, for institutions that use VAR, each must choose the parameters that produce the greatest insight to help them measure and manage the specific market risks that face the portfolio.

SFor central banks, it may be more appropriate to focus on longer periods. For example, it may be more useful to measure monthly returns and use a 92 percent confidence level ( 11 months out of 12 equals 91.67 percent). 


\section{Using Value-at-Risk with an Investment Benchmark}

In many cases, investment benchmarks are chosen as duration targets, where the benchmark's sensitivity to changes in interest rates is judged to properly balance return and market risk. As discussed earlier, a shortcoming of duration is that it does not incorporate yield volatility and, thus, does not directly equal price risk. Since VAR incorporates yield volatility, VAR may offer some insights into the selection of a benchmark. By defining an investment period, selecting a confidence level, and calculating the VAR of the benchmark portfolio with the target duration, the board will have a better expectation of the losses that can occur in the normal pursuit of returns. Naturally, if the VAR is judged to be too high, the benchmark should be revised by shortening its duration and the exercise should be repeated.

This process of benchmark review can also help solve a dilemma of portfolio management. Portfolio management relative to a benchmark works well when actual portfolio returns exceed those produced by a benchmark, which itself produces favorable returns (see Figure 14.7). However, the dilemma arises when the benchmark produces unfavorable returns. In this case, a portfolio manager's performance may be viewed badly even if the portfolio returns exceed those of the benchmark. Calculating VAR can help this situation because it directly highlights the possibility of losses in the pursuit of return. Using this approach, as long as the benchmark's returns remain within the acceptable range (more favorable than the VAR), a portfolio manager's excess returns should be viewed favorably and, conversely, returns less than those of the benchmark should be viewed unfavorably. When the returns of the benchmark are worse than the maximum expected loss (as will happen occasionally) but the portfolio returns exceed those of the benchmark, it should be more natural to review the assumptions that led to the adoption of the benchmark than to blame the portfolio manager for poor performance.

Before leaving this topic, it is important not to leave the impression that duration should be replaced by VAR. Duration is a useful tool because it is intuitive and is a key part of the standard jargon of the investment business. Understanding the portfolio's VAR will add additional insight, but even with their limitations, intuitive and market-tested tools such as duration should not be abandoned in 
Figure 14.7. Performance of the Portfolio Versus the Benchmark

Performance of the Portfolio

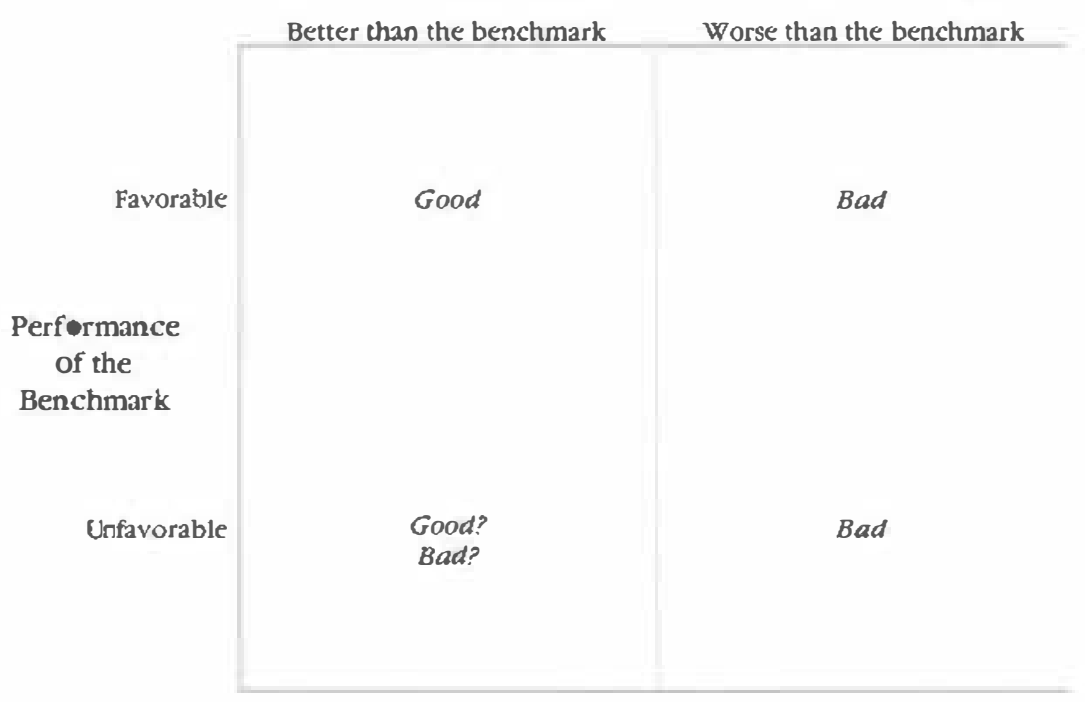

favor of "modern" technology. In particular, duration remains a useful tool in the day-to-day management of portfolios, while VAR is most useful as an institutional-level management tool.

\section{Measuring Other Risks}

VAR is a useful quantitative approach for measuring market risk, but offers no information about other risks. For credit risk, legal risk, and operations risk, it is far more difficult to quantify the distribution of expected losses, but this difficulty should not result in avoidance. Even though judgment is required, it is useful to ask whether the portfolio is subject to losses due to the failure of a counterparty, losses due to an adverse ruling by a legal entity, or losses due to fraud. If these risks exist, some effort should be spent in trying to quantify their magnitude and control them. Another risk that is worthy of further consideration is liquidity risk, which is certainly a central bank concern. Since liquidity risk is the lack of a reasonable market for the securities that, by definition, may need to be liquidated quickly, it would be useful to quantify the loss due to accepting a distress bid or the loss associated with being forced to 
hold a security until maturity. Furthermore, some of these risks (counterparty failure and liquidity risk) may be correlated with market risk. With all of the risks other than market risk, the available tools are less developed but, as mentioned earlier, they may represent some of the biggest risks faced by central banks and, therefore, must not be overlooked.

\section{Risk Management Systems}

In the current environment, most central banks have sophisticated technology at the fingertips of their portfolio managers. This technology allows for monitoring the portfolio, calculating yield and duration, updating managers about market conditions, and gathering indicative and historical data about potential purchases. While this technology may work well in the dealing room, an effective risk management process may necessitate additional technology. For risk management, it is useful to have systems that offer:

- electronic price validation (by multiple market makers);

- portfolio aggregation (across currencies and security types);

- coverage of all holdings and consistent calculations of risk;

- VAR calculations;

- portfolio stress testing to explore the tails of the return distribution; and

- flexibility and expendability.

First, since manual price validation can be cumbersome and timeconsuming, risk management systems should allow for electronic (and frequent) market updates. With the availability of many market data vendors, this requirement should not be difficult to achieve. Second, systems should allow for easy aggregation of portfolio holdings. The faster that portfolio holdings can be gathered and updated, the faster that the risk management process can identify unanticipated risks. Third, coverage of all holdings is important. If holdings are missing or are difficult to analyze, the measurement of portfolio risk may be incomplete or inconsistent. Fourth, as discussed earlier, VAR calculations can add to an understanding of portfolio market risk. Fif th, since VAR does not cover the entire distribution of returns, it is usefill to have technology that helps examine the impact of extreme events on the portfolio. Sixth, systems 
should be designed for flexibility and expendability. It is impossible to define the scope of future investments with precision, and thus, technology will need to he updated periodically. For example, the advent of EMU will change the way that many central banks invest. Flexible technology will allow for necessary changes as EMU takes shape or as new security types become attractive investments.

\section{Rules of Behavior}

Once the risk management process has defined the risks that are relevant to the portfolio, and technology has been put in place to assist in measuring and monitoring the risks, the actual management process should take place, where rules are defined and compliance is checked. In a risk management context, rules may be necessary to control the following:

- deviations from the benchmark;

- limitations on portfolio duration;

- VAR limits;

- individual position limits; and

- requirements for portfolios or counterparty diversification.

For risk management, there should be some method for contro!ling market loss. This control can take the form of duration limits, which is an intuitive way to control price volatility, or a VAR limit, which directly incorporates yield volatility. Furthermore, there should be some rules about diversification, within individual positions, throughout the portfolio, or with counterparties. It may be difficult to directly address credit risk, legal risk, liquidity risk, and operations risk, but a well-diversified portfolio should help mitigate some of these risks.

\section{Mechanism to Check Compliance}

Even with careful planning and a rigorous risk management process, some of the costliest risks may be the ones that are not anticipated and stem from noncompliance with the sules. Therefore, it is necessary to have checks and balances to ensure that the process works as planned. In this vein, there should be a mechanism to check compliance, which should include: 
- independent risk audits;

- reports to management about risk levels; and

- penalties for violating risk management rules.

First, the risk management process should be audited periodically in the same way that financial records are audited, with an eye toward fair and accurate representation. Second, the managers of the investment department (and the board) should receive regular reports that def ine risk levels and identify deviations from the benchmark, excessive market risk, lack of diversification, and unfavorable trends. Third, there must be some mechanism for stopping "risky" behavior, which should include penalties for violation of the rules of behavior.

\section{Performance Attribution}

The final stage in the risk management process is "return attribution," the only backward-looking part of the process. Performance attribution should:

- examine the sources of portfolio return (adjusted for level of risk);

- audit the entire risk management process; and

- lead to more appropriate rules over time.

After each investment period, it is important to ask: How and why did the portfolio perform as it did? In this review process, it is also necessary to measure the performance of the benchmark and to examine its sources of return. For example, how much return came from yield, how much from changes in the overall level of interest rates, how much from changes in yield curve shape, and how much from deviations from the benchmark? If possible, these returns should be calculated including some measure of the risk taken. This is important because, for example, if the portfolio underperformed the benchmark because the portfolio manager decided to reduce exposure to market risk, perhaps this is a better outcome than it might appear at first glance. Also, it is critical to examine how the portfolio performed relative to its VAR target. Was our actual risk consistent with our expected risk? For example, if the portfolio had a 95 percent confidence level, was the VAR exceeded more than one day in 20? Return attribution helps audit the entire risk management process by focusing on the process after the event. Was 
our risk level appropriate? Did we take too many correlated risks? Did we stop risky behavior? By setting a process in place and monitoring its performance, the risk management process should evolve and improve with time.

\section{Conclusions}

The current focus on risk management is simply a clarification of an existing process with some new tools and a new focus on anticipating risks. It is not a revolutionary approach to investment management. Indeed, the process of managing assets has often been characterized as the management of risk. The appropriate risk management process for each central bank must follow the individual objectives of that bank, and should follow basic, intuitive, common sense rules that individuals can easily endorse and follow because, in a real sense, risk management is everyone's business.

Risk management is a process of defining what is expected (in terms of both portfolio and individual performance) and allowing actual events to either confirm or challenge your faith in your expectations. When expectations are challenged, a "call to action" should follow that forces a questioning of assumptions, an alteration of the investment benchmark, or a possible change in policies or risk tolerances.

The pursuit of return almost always requires the acceptance of some level of risk. It is far better to anticipate risk and make appropriate preparations rather than to fear risk or, worse yet, ignore it and suffer unexpected losses in the future. 


\section{5 \\ Technical and Quantitative Aspects of Risk Management}

\section{Erol Hakanoglu}

Tn this paper, I will try to focus on some of the more technical and can apply equally to assets or liabilities. In particular, we will focus on some of the classic issues and questions of how we determine maturity profile, fixed-to-floating ratios, and currency composition, but also on some of the other issues raised previously such as the proper measures of risk. Along the way, we also address problems facing some sovereign borrowers-many of which probably do not have the luxury to go along with the "theorem" Mike Dooley suggested: issuing at the longest maturity in the domestic currency. Linfortunately, it is seldom the case that emerging market sovereigns have the luxury to be able to borrow for 30 years in their domestic markets in significant amounts.

In general terms, strategic liability and/or asset managers need to set an appropriately long horizon for themselves, and come up with some sort of optimization framework that will give them a sense of what the best performance of a portfolio relative to a benchmark is. If we were to follow the results of such an optimization and rebalance our portfolio accordingly, say by either issuing new debt or swapping existing debt to change its currency, or maturity, or fixedfloating composition, we should have a portfolio that reflects our preferences, or utility, more effectively than before.

Optimization is something that can be both an art and a science. Whenever one rebalances a portfolio, the assumptions being made are going to be important. Hence, one needs to come up with a 
strategy that, even on contrarian scenarios, guarantees that one still ends up better off than not following the recommended course of action. With a rebalancing strategy that is robust enough, one should be better off in the contrarian scenarios as well. This should be the conditions of optimality, not the ones that give a better utility only if one's views about the fiture are correct. Since it is not obvious that one will be able to satisfy such stringent conditions each time one tries to optimize, perhaps sometimes one should not rebalance at all unless this "robustness" criteria has been satisfied. I believe this is the right way to think about asset, liability, and risk management in general.

\section{Development of a Framework}

The Goldman Sachs Multicurrency Asset-Liability Management Model uses Monte Carlo simulations to characterize the probable fitture behavior of asset or liability porfolios. The Monte Carlo simulation approach necessitates the preparation of an elaborate probabilistic framework to model the behavior of economic and financial variables. Here are the steps we take:

(1) Choosing appropriate stochastic processes to model the variables involved. Most market variables, such as interest rates and exchange rates, are often modeled as lognormal, and their defining parameters are estimated from historical data and current market prices. However, sometimes it might be necessary to use other less traditional stochastic processes such as Poisson jumps.

(2) Construction of a bistorical variance/covariance matrix for all variables. This includes discussion of which periods to include in this estimation and what weights to use for each period.

(3) Selection of an appropriate short-term horizon. This is for tactical analysis and an appropriate long-tern horizon for strategic analysis.

(4) Making appropriate "rollover" csssumptions. This is done for all the various classes of instruments in the liability portfolio.

(5) Deciding on the list of financial strategies, such as:

- fixed and floating rate new debt issues; 
- refunding of callable debt or implementation of strategies, such as selling swaptions or warrants to monetize the embedded options of callable bonds;

- repurchasing of noncallable outstanding debt;

- interest rate swaps;

- cross-currency swaps;

- forward and futures contracts;

- options on interest rates, exchange rates, indices or commodities, structured notes, and swaps;

- inflation-linked debt issues;

- foreign exchange-linked debt issues; and

- customized hedging instruments.

(6) Determination of future cash.flows-resulting from all instruments in the current debt and asset portfolios and all the rebalancing strategies considered.

\section{Simulation}

The Goldman Sachs Multicurrency Asset-Liability Model uses Monte Carlo simulations extensively. The methodulugy includes generating thousands of realistic scenarios for future exchange rates, interest rates, and other relevant variables, and computation of cash flows resulting from individual instruments in the portfolio as well as the revenues and expenses of the sovereign. This computation might also involve the simulation of the decision-making process of the portfolio manager in cases such as deciding when to refund callable bonds.

Given a particular scenario, the cash-flow set of each instrument is determined by the market conditions over that scenario. For example, the cash flows of a domestic floating rate note depend on the relevant domestic interest rate, while the cash flows for a foreign bond depend on the relevant exchange rate. We can then proceed with measurement of the net present value (NPV) and average annual cost/retum of each instrument under each scenario. Following steps include construction of the probability distribution of the average annual cost/return of each instrument, and measurement of the expected cost/return as the mean of the distribution. Then we construct the probability distribution of the average annual cost/return of the overall portfolio over the long term, as well as the short term, by aggregating the results for individual instruments. We con- 
clude simulations by determining the impact of incrementally changing the currency composition, maturity profile, or fixed/floating mix of the asset and liability portfolio.

\section{Risk Measurement}

A detailed discussion of risk measurement methods is an important step in the liability management process. Goldman Sachs believes that the risk measurement methods that are to be developed for the sovereign should be:

- quantitative;

- objective;

- comprehensive;

- isolating the actions of the sovereign from market moves beyond the control of the sovereign; and

- analytically straightforward to implement.

The conventional measure of risk for a liability portfolio is the standard deviation of the cost distribution. More sophisticated measures take into account the fact that not all uncertainty is unfavorable: high interest cost scenarios are risky while low interest cost scenarios are not. Such a one-sided approach will allow us to separate negative uncertainty from positive uncertainty. One-sided risk measures can be used to take into account asymmetric utility functions that place greater weight on the penalty of potential interest cost increases than on the benefits of equivalent potential interest cost savings.

One-sided risk can be defined in a variety of ways. The probability of exceeding a fixed cost level (derived from expected cost of the current porffolio under forward rates or budgetary considerations of the sovereign) could be used as a performance criterion. However, a fixed cost level is too restrictive to incorporate essential information about various sources of interest rate, exchange rate, or liquidity risk. It is not flexible enough to reflect the sovereign's debt management objectives and capital markets constraints.

A systematic way to quantify risk in a sophisticated, reliable, and flexible manner is to measure risk against a benchmark portfolio that is constructed to take into account various market and nonmarket constraints and concerns of the portfolio manager. After the 
development of such a benchmark portfolio, risk can be defined as the underperformance of the portfolio relative to the benchmark.

The most important sources of risk that a sovereign borrower needs to address can be summarized as follows:

- liquidity risk;

- interest rate risk;

- cash-flow uncertainty;

- rollover risk;

- mark-to-market risk;

- exchange rate risk; and

- credit risk.

The Goldman Sachs Asset-Liability Management Model is capable of measuring risk from a cash-flow perspective and from a mark-tomarket perspective. In the past, asset managers have traditionally focused on mark-to-market uncertainty, while liability managers have focused on cash-flow uncertainty. These two approaches often lead to different results. For example, long-term fixed rate bonds are riskless from a cash-flow perspective, but risky from a mark-to-market perspective. Floating rate notes, on the other hand, exhibit the opposite characteristic. Goldman Sachs believes that it is essential to consider both forms of risk simultaneously.

The budgetary targets of the sovereign will be thoroughly examined during the risk measurement and benchmark selection parts of the Asset-Liability Management analysis. We will also analyze the methodology by which the sovereign determines these targets and evaluate their advantages and disadvantages as performance measurement tools.

\section{Selection of a Strategic Benchmark}

Selection of a strategic benchmark constitutes the pillar of the Goldman Sachs Asset-Liability Management approach. We believe that the success of any risk management effort is heavily dependent on the appropriateness of the underlying performance benchmark. A benchmark portfolio is a convenient way to aggregate various market exposures as well as many factors constraining the portfolio choice. We will work on both the liability portfolio and the liquid reserve portfolio during the benchmark selection process. 
The risk of a fiability portfolio can be measured in a variety of ways. One common approach is to determine the expected cost of the existing porfolio over a chosen horizon under forward rates and to use the probability of underperforming this fixed cost level as a performance criterion. An alternative method is to use the probability of the cost of debt being above an absolute amount dictated by budgetary considerations. However, such fixed rate benchmarks do not properly take into account relevant information from sources other than the immediate debt portfolio, which could affect the interest rate, exchange rate, commodity price, and liquidity risk of the sovereign. For example, trade and capital flows, liquid asset and reserve portfolios, tax revenues, policy guidelines, and macroeconomic variables can all be important factors affecting porffolio choice and risk considerations.

A simple way to conceptualize the strategic benchmark portfolio is to treat it as a default long-term portfolio designed to have a currency composition, maturity profile, and fixed/floating mix that reflects the riskless position for the sovereign in the long run. This concept can be expanded to incorporate the borrowing goals, capital markets objectives, and policy constraints of the sovereign.

The factors that will most likely impact the currency composition of the benchmark portfolio are:

- historical statistical relationships between exchange rates;

- relative bond market sizes in various currencies;

- new issue spreads of the sovereign in these markets; and

- the impact of foreign exchange flows on the economic activity level and the tax revenues of the sovereign.

The factors that are most likely to impact the maturity profile of the benchmark portfolio are:

- revenue and expense forecasts of the sovereign over the next few years;

- repurchase or tender plans;

- liquidity concerns of the sovereign; and

- spreading of cash flows over the years in order to smooth refinancing exposure.

The factors that are most likely to impact the fixed/floating mix of the benchmark portfolio are:

- targeted interest expense levels of the sovereign from the budget; 
- the interest rate views of the sovereign;

- relationship among tax revenues, business cycles, and interest rates;

- historical cost of fixed versus floating rate debt; and

- relative risk of foreign fixed and floating issues in comparison to domestic debt.

Other factors that need to be considered during the development of the benchmark portfolio are:

- continuing accessibility of various markets considered;

- the need to maintain high-volume debt issues to achieve market liquidity, efficiency, and long-term cost benefits such as facilitating future repurchases or tenders;

- the relationship between commodity prices, exchange rates, and domestic macroeconomic variables;

- accounting guidelines;

- policy constraints limiting the use of certain financial instruments; and

- mark-to-market rules for derivative instruments.

A benchmark portfolio that is created by taking into account all the issues mentioned above is a fairly close approximation of the "ideal" long-term portfolio of the sovereign. It will represent a minimum risk position for the sovereign, since it will be constnucted to take into account all the various market exposures, long-term objectives, and market and policy constraints the sovereign is operating under. As the benchmark portfolio will be selected to represent primarily the strategic preferences of the sovereign, tactical deviations from the benchmark portfolio can be undertaken periodically to take advantage of market opportunities and to reduce cost.

Using a strategic benchmark for risk management has several advantages. It creates a structure that ensures that future strategies conform to the strategic risk management objectives of the sovereign. It provides a straightforward method of combining many of the diverse factors affecting the portfolio choices of the sovereign. It allows the sovereign to set limits on risk tolerance levels and creates a mechanism to enforce these levels. Once the benchmark is in place, portfolios can be optimized within well-defined parameters and their performance can be judged on objective criteria. 


\section{Formulation of Strategies}

A primary objective of the liability management study is to develop strategies to enhance the cost/risk profile of the liability portfolio. We list below some examples from previous sovereign liability management studies to demonstrate our approach toward formulation of strategies. We are able to add many more to this list after studying the specific information provided to us by the sovereign. These may include:

- Calculation of the impact of changing the maturity profile, fixed/floating ratio, and currency composition on the cost and risk of the liability portfolio.

- Identifying the effect of buying caps and floors on the probability of falling short of budget targets.

- Examining ways to reduce the expected cost of hedging instruments through knock-in and knock-out features.

- Performing a refunding efficiency analysis for callable bonds in the liability portfolio to determine whether any call options are sufficiently in the money to justify calling the bond.

- Exploring alternative strategies such as selling swaptions or warrants to monetize the value in the embedded options of the callable bonds.

- Designing new issue strategies to replace called bonds or to fulfill new funding needs of the sovereign.

- Exploring the possibility of linking debt payments to inflation and foreign exchange rate levels.

- Structuring of custom-tailored hedging instruments that precisely hedge market exposures of the sovereign.

- Exploration of derivative structures that hedge multiple exposures together in a cost-effective way.

\section{Optimization}

The objective of the cost/risk optimization section of the Goldman Sachs Asset-Liability Management Model is to determine to what extent the cost/risk profile of the asset and liability portfolios can be improved and to select the most effective transactions to do so. We define a portfolio to be optimal if it is the lowest-cost port- 
folio for a given level of risk or, equivalently, if it is the lowest-risk portfolio for a given level of cost.

The efficient frontier is the set of optimal portfolios. A portfolio that is not on the efficient frontier is not optimal because there exists a portfolio with both lower cost and lower risk. The slope of the efficient frontier quantifies the cost/risk trade-off associated with different strategies.

The choice of which optimal portfolio to select depends ultimately on the borrower's risk tolerance. A borrower with a high-risk tolerance will prefer a strategy that minimizes cost, while a borrower with a low-risk tolerance will prefer a strategy that minimizes risk.

Over the course of the liability management analysis, we will perform a rebalancing optimization-to find the best strategies to change the composition of the debt portfolio without changing its size. Then we will perform a new issue optimization, to find the best ways to increase the size of the debt portfolio. Finaliy, we will perform a refunding efficiency analysis to determine optimal ways to reduce the size of the debt portfolio.

\section{Sensitivity Analysis}

The sensitivity analysis allows us to test potential restructuring strategies against various potential market moves and ensure that they perform within acceptable risk parameters.

A sensitivity analysis can be performed in a discrete form or in a simulation framework. A discrete sensitivity analysis measures the performance of a strategy under an elaborately defined future path of market variables. A simulation-based sensitivity analysis involves repeating the scenario generation, cash-flow simulation, and portfolio evaluation steps described earlier under alternative scenarios, where different expected future levels for exchange rates and interest rates are used. The Goldman Sachs Multicurrency Asset-Liability Management Model has the capability to perform both types of sensitivity analyses.

There are many ways of constructing sensitivity scenarios. One common choice is using shock scenarios, where interest and exchange rates are subjected to parallel one or two standard deviation moves up and down from their base-case levels. Another is to cre- 
ate contrarian scenarios, which represent the opposite views from the base-case scenario with respect to implied forward rates or specific forecasts.

In addition to the scenarios described above, a robust sensitivity analysis should focus on adverse scenarios that are picked specifically to determine how poorly certain strategies perform under extremely unfavorable market conditions. This can be done by performing another set of Monte Carlo simulations that are adjusted specifically to assign more probability to adverse market moves, or by simulating the behavior of potential strategies through actual past observations to determine the worst possible historical outcomes. Goldman Sachs recommends only strategies that either outperform the existing portfolio or perform within acceptable risk parameters under all sensitivity scenarios.

The Goldman Sachs approach to sensitivity analysis is not limited to calculating the sensitivity of the results to changes in market variables. We also determine the effects of changing the composition of the strategic benchmark or relaxing some of the policy guidelines. 


\section{Notes on Contributors}

Rick Battellino is currently Assistant Govemor (Financial Markets) of the Reserve Bank of Australia. He has been in this position since 1994. His responsibilities are to oversee the Reserve Bank's operations in domestic and foreign exchange markets-including implementation of domestic monetary policy, foreign exchange intervention, and management of international reserves. Mr. Battellino has been employed by the Reserve Bank since graduating from university in 1973. During this time, he has occupied a number of positions in the Economics and Financial Markets areas of the Bank. Immediately prior to his current position, he was Head of the International Department.

Marcel Cassard is Chief Economist for Emerging Europe, Middle East and Africa for Deutsche Bank. Before joining Deutsche Bank. Marcel spent five years as an economist at the International Monetary Fund, in the International Capital Markets Division of the Research Department. Prior to that, he was an International Economist at the Council of Economic Advisers in Washington and a Consultant at the Organization for Economic Cooperation and Development (OECD) in Paris. He earned a B.A. in Economics and Mathematics from Washington University, St. Louis, in 1981 and a Ph.D. in Economics from Columbia University in 1993. Marcel has written various articles and working papers in the field of international economics and sovereign debt management.

Patrick de Fontenay is a former Director of the IMF Institute and Chairman of the Investment Committee of the IMF Staff Retirement Plan. Mr. de Fontenay has a Ph.D. from Yale University and LI.D from the University of Paris. He is a citizen of France.

\section{CInternational Monetary Fund. Not for Redistribution}


Iouis de Montpellier was most recently General Advisor of the Treasury of the Kingdom of Belgium. As a member of the Treasury management team, he focused on the development of the Kingdom's funding strategy and debt management in the domestic and international markets. Before this, he was Director of Funding of the European Bank for Reconstruction and Development in London for four years. He joined the EBRD from CS First Boston in London where he was a capital market/covering officer for Belgian and French institutional clients. Previously, he worked as an institutional portfolio manager for central banks with the Bank for International Settlements in Basle. Mr. de Montpellier holds a Master in Law from the Catholic University of Leuven, a Master in Economics from the Catholic University of Louvain, and a MBA from the Johnson Graduate School of Management, Cornell University.

Michael Dooley is a Professor of Economics at the University of California, Santa Cruz. He is also a Research Associate at the NBER and an editor of the International Journal of Finance and Economics. He served on the staff of the Federal Reserve Board during 1971-82 and, the Research Department of the International Monetary Fund, during 1982-92. His research deals with exchange rate detemination, intemational capital movements, capital controls, debt management policy, and issues associated with sovereign debt.

David Folkerts-Landau is Managing Director and Global Head of Research at Deutsche Bank. Before joining the private sector in October 1999. Mr. Folkerts-Landau was Assistant Director in the IMF's Research Department in charge of international capital markets surveillance. He earned a B.A. from Harvard University in 1973 and a Ph.D. in Economics from Princeton University in 1977. Mr. Folkerts-Landau taught economics at the Graduate School of Business of the University of Chicago before joining the IMF's Research Department in 1980. He is the author of several books and articles on financial economics.

Francis Glenister is a Managing Director of Salomon Smith Barney and Head of Fixed Income Research in Europe. Mr. Glenister has worked extensively with both clients of Salomon Smith Barney and the firm's trading desks on risk management and related portfolio management issues. Mr. Glenister joined the firm in 1983 after earning an MBA from Manchester Business School and an MA in Natural Sciences from Cambridge University.

Erol Hakanoglu heads the Srategic Risk Management Advisory Group, which he founded at Goldman Sachs. The group assists corporate and sovereign clients in determining and managing their overall exposure to movements in interest rates, exchange rates, and commodity prices, as well as 
their significant operational exposures using state-of-the-art quantitative models. The group also specializes in creating optimal hedging strategies to mininize aggregated risk at the lowest possible cost. Previously, at Goldman Sachs, he worked with the late Fischer Black on options valuation and term structure of interest rates. Prior to joining the firm, Dr. Hakanoglu taught at Harvard, where he received his Ph.D.

It Hansen is the Head of Department, Financial Markets Department, at the Danmarks National Bank.

Philippe Jorion is Professor of Finance at the Graduate School of Management at the University of California at Irvine. He has also taught at $\mathrm{Co}$ lumbia University, Northwestern University, the University of Chicago, and the University of British Columbia. He has authored more than fifty publications for academics and practitioners on the topics of risk management and international finance. His recent work addresses the issue of forecasting risk and return in global financial markets, as well as managing exchange rate risk with derivative instruments.

Thomas E. Klaffky is a Managing Director of Salomon Smith Barney and Head of Global Fixed Income Research. Prior to being named to his current position in 1995, Mr. Klaffky was the head of the Bond Portfolio Analysis Group, the quantitative arm of Fixed Income Research. Mr. Klaffky joined the firm in 1976 after receiving a B.A. in Economics from C.W. Post College in 1975 and an MBA in Finance from New York University in 1976. Mr. Klaffky is the author of several research publications covering such topics as risk management, portfolio strategy, zero coupon bonds, and fixed income benchmarks.

Gregory D. Makoff is currently a member of the International Liability Management group at Salomon Smith Barney. He has worked for Salomon since 1993, specializing in the structuring and execution of liability management transactions for sovereigns and corporations. He earned a B.S. in Physics and a B.S. in Political Science from the Massachusetts institute of Technology in 1986 and a Ph.D. in Physics from the University of Chicago in 1993.

Judith B. Otterman is a Vice President in the Research Department at Salomon Smith Barney, where she focuses on structuring and analyzing fixed-income portfolios. Prior to this, she was the Head of the Income Indexes Group. Ms. Otterman joined the firm in 1986 after graduating from UCLA with a BS in Mathematics.

John Nugée is currently the Chief Manager in charge of Reserves Management at the Bank of England. He started his career at the Bank of England in 1977. After spells in economic and statistical research and computer 
programming, he moved in 1986 to the Bank's Foreign Exchange Division. Here he held a variety of portfolio management and strategic investment management positions, culminating in the post of Trading Manager for the UK's Foreign Currency Reserves in 1990-91. From 1992 to late 1996, Mr. Nugée worked in Hong Kong, where he was the Executive Director in charge of Reserves Management at the Hong Kong Monetary Authority. He returned to the Bank of England in 1996 to take up his cun'ent post.

Alejandro M. Pilato is Managing Director of Tokai Bank Europe plc and Tokai Capital Markets, responsible for risk advisory, client derivatives and primary markets. He was previously a Director at ISSBC Markets (1994-96) responsible for risk management advisory services. Before joining HSBC, he was Vice President at JP Morgan (1987-94), responsible for the portfolio groups providing advice to corporate and sovereign clients on strategic risk management, debt optimization and asset allocation. Dr. Pilato joined JP Morgan's quantitative research department in 1987. He was awarded a BSc degree in Theoretical Physics from the University of London in 1982 and a D.Phil degree in Mathematics from Oxford University in 1986. Dr. Pilato is a Fellow of the Institute of Mathematics and its Applications and has published a number of mathematics papers in scientific journals.

Bengt Ràdstam is Deputy Director and Head of Portfolio Management and Analysis at the Swedish National Debt Office. He has described how the foreign currency debt is managed in a recent Euromoney publication, Excellence in Debt Management: The Strategies of Leading International Borrowers (see chapter 6). His previous experience includes positions as University Lecturer in Economics at the University of Uppsala (1968-74) and as Chief International Economist at the National Institute of Economic Research (1974-80). He has also held numerous public and private sector positions and is currently a member of the Finance Committee of the City of Stockholm and an external advisor to the Scandinavian Airlines System (SAS).

Jean-Françols Rigaudy is Deputy Head of the Treasury at the Bank for International Settlements in Basle, where he has worked since 1988. Before that he worked in the International Department at the Banque de France where he contributed to the management of foreign exchange reserves. At the beginning of his career at the Banque de France he was involved in banking supervision. Mr. Rigaudy holds degrees in law and history and has a diploma from the Institut d'Etudes Politiques de Paris, where he also lectured from 1984-88.

Paul Sullivan is Director of Strategy and Risk Management at the National Treasury Management Agency (NTMA) in Ireland. Prior to joining the NTMA early in 1991, at the time of its establishment, he was a Vice Presi- 
dent of Chase Manhattan Bank, holding a number of senior international management positions in the Middle East, London, and New York. He spent almost fourteen years with Chase (1977 to 1991) and his responsibilities at the Bank included the management of all international domestic currency funding, treasury liability management, and the management of the Bank's Continental European treasury, foreign exchange, and capital markets activity. Prior to joining Chase Manhattan he had worked in Dublin with the Central Bank of Ireland and the Industrial Credit Company. Mr. Sullivan holds degrees in economics from both University College Dublin and Trinity College as well as a degree in Finance, also from University College Dublin. He has written a paper on ireland's debt management included in Excellence in Debt Management: The Strategies of Leading International Borrouers, published by Euromoney.

Graeme Paul Wheeler is the Director of the Financial Products and Services Department in the Treasury of the World Bank. For four years before joining the Bank, he was the Treasurer of the New Zealand Debt Management Office (NZDMO) and Deputy Secretary to the New Zealand Treasury. Prior to this, he was Directer of Macroeconomic Policy and Forecasting in the New Zealand Treasury. In the second half of the 1980s, Mr. Wheeler was the Economic Counselor for the New Zealand Delegation to the Organization for Economic Cooperation and Development (OECD) in Paris and he headed the New Zealand delegation in meetings that led to the establishment of the European Bank for Reconstruction and Development (EBRD). He joined the New Zealand Treasury in 1973. 